Portland State University

PDXScholar

Summer 9-18-2015

\title{
Antimalarial Drug Discovery using Triazoles to Overcome Chloroquine Resistance
}

Elias Sibhatu Tesfaselassie

Portland State University

Follow this and additional works at: https://pdxscholar.library.pdx.edu/open_access_etds

Part of the Medicinal-Pharmaceutical Chemistry Commons Let us know how access to this document benefits you.

\section{Recommended Citation}

Tesfaselassie, Elias Sibhatu, "Antimalarial Drug Discovery using Triazoles to Overcome Chloroquine Resistance" (2015). Dissertations and Theses. Paper 2506.

https://doi.org/10.15760/etd.2503

This Thesis is brought to you for free and open access. It has been accepted for inclusion in Dissertations and Theses by an authorized administrator of PDXScholar. Please contact us if we can make this document more accessible: pdxscholar@pdx.edu. 
Antimalarial Drug Discovery Using Triazoles to Overcome

Chloroquine Resistance

by

Elias Sibhatu Tesfaselassie

A thesis submitted in partial fulfillment of the requirements for the degree of

Master of Science

in Chemistry

Thesis Committee:

David H. Peyton, Chair

Robert Strongin

David Stuart

Portland State University

2015 
(C) 2015 Elias Sibhatu Tesfaselassie 


\begin{abstract}
Malaria is considered as one of the most prevalent and debilitating diseases affecting humans. Plasmodium falciparum is the most virulent form of the parasite which developed resistance to several antimalarial drugs. Chloroquine is one of the most successful antimalarials developed that is safe, effective, and cheap. However, its use has been limited due to the emergence of drug resistance. Click chemistry, particularly, the copper(I)-catalyzed reaction between azides and alkynes has shown to have a cuttingedge advantage in medicinal chemistry by its reliability, selectivity and biocompatibility.

Triazole-based antimalarials were synthesized via copper(I)-catalyzed alkyne-azide cycloaddition reaction by modifying the aliphatic chain terminal of chloroquine. The compounds synthesized contain triazole ring directly connected to an aromatic ring or via a piperazine linker. When tested for their in vitro antimalarial activity against D6, Dd2 and 7G8 strains of P. falciparum, 12 out of 28 compounds showed better activity against chloroquine resistant strains. Particularly, PL403 and PL448 exhibited potent activity than chloroquine against CQ-resistant strains $\mathrm{Dd} 2$ and $7 \mathrm{G} 8$, with $\mathrm{IC}_{50}$ values of 12.8 \& $14.5 \mathrm{nM}$, and $15.2 \& 11 \mathrm{nM}$ respectively.
\end{abstract}

The efficiency of synthesizing several triazole-based antimalarials have proven click chemistry to be fast and efficient reaction. Generally, para-substitutions and disubstitutions with electron-withdrawing groups were found to be beneficial for having better antimalarial activity for these group of click compounds. Moreover, the incorporation of piperazine linker has brought an enhanced antimalarial activity. 


\section{DEDICATION}

To my mother, Zaid Araya, for her continuous love,

care and support. 


\section{ACKNOWLEDGEMENTS}

First and for most, I would love to give praise to the almighty God, for his grace and mercy. My deepest gratitude and appreciation goes to my advisor, Dr. David H. Peyton, for believing in me, and his invaluable advice and support both as mentor and father. I extend my gratitude to Peyton lab groups: Dr. Katherine Liebman for sharing her synthesis knowledge with me, Rob Jensen for having a positive heart to always help me in NMR spectroscopy and other skills, as well as to Kelsie Kendrick, Cheryl Hodsen, Kevin Murphy and Anna Duell.

I also would like to extend my gratitude to Dr. Robert Strongin and Dr. David Stuart to be a part of my thesis committee, for their advice and spending time in editing the draft. I want to acknowledge the assistance of my undergraduate student Scott Harris in preparing starting materials; Dr. Jane X. Kelly \& Dr. Yuexin Li in testing my compounds; Sunil Sundalam for giving me hand in mass spectrometer; Dr. Josephrajan Thainashmuthu for his advice in click chemistry and borrowing chemicals; and the chemistry department for their general support.

Finally, I want to give thanks to my family and friends, particularly for my siblings for their motivation and support. 


\section{TABLE OF CONTENTS}

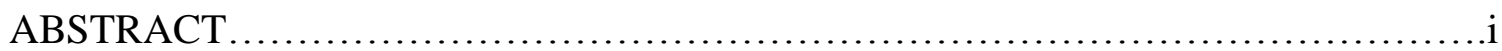

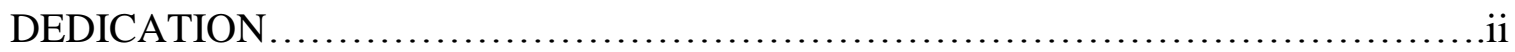

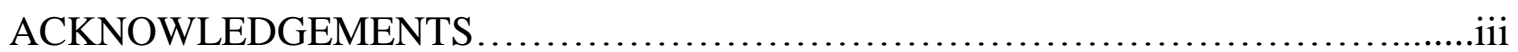

LIST OF TABLES ..................................................................

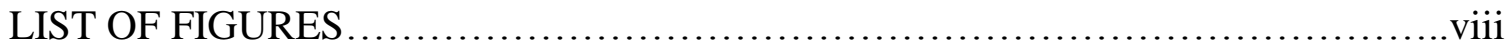

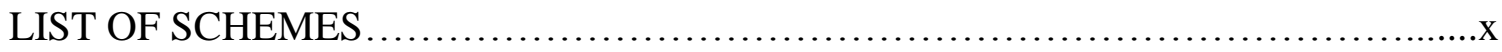

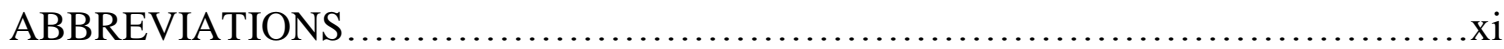

CHAPTER 1: Malaria..................................................................

1.1. Introduction and epidemiology ..........................................

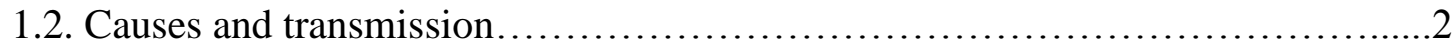

1.3. Symptoms and diagnosis................................................

1.4. Treatment and prevention..................................................

1.5. Antimalarial chemotherapy ................................................ 8

1.6. Resistance to antimalarial drugs............................................ 13

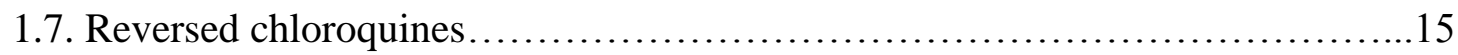

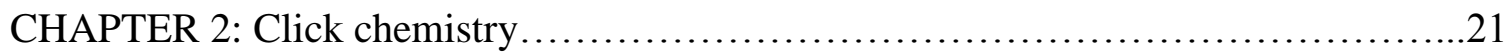

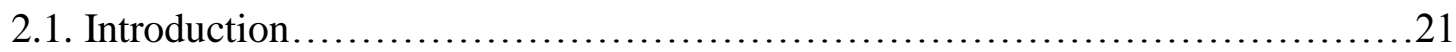

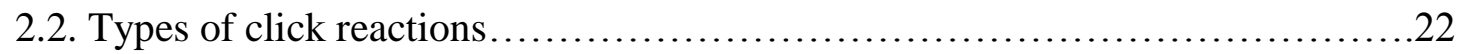

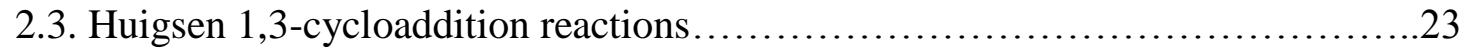

2.4. Copper-catalysed azide-alkyne cycloaddition reactions.......................25 


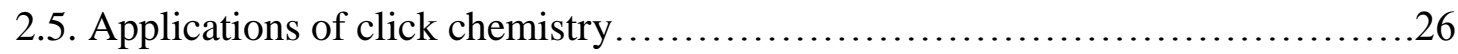

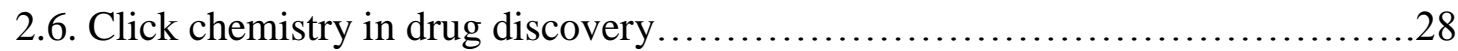

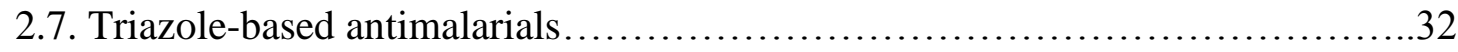

2.8. Triazoles as pharmacophores, bioisosters, and linkers..........................34

CHAPTER 3: Synthesis of 1,2,3-triazole-based antimalarials..........................39

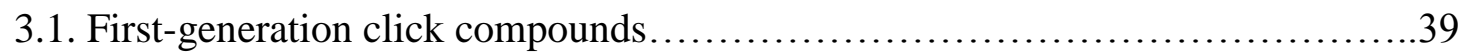

3.2. Para-phenyl substituted triazoles..........................................41

3.3. Triazole with reversal agent pharmacophore ................................43

3.4. Para-phenyl substituted terminal alkynes...................................44

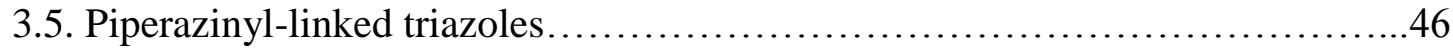

3.6. Triazole-based bisquinoline antimalarial....................................48

CHAPTER 4: Structure-activity relationships of triazole-based antimalarials...........50

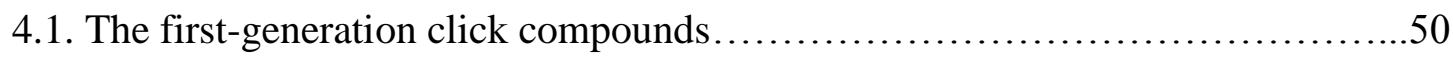

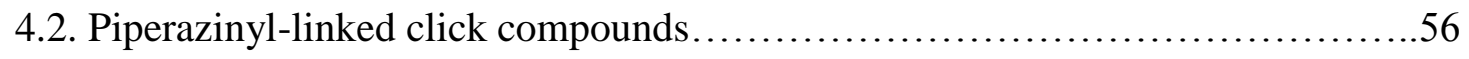

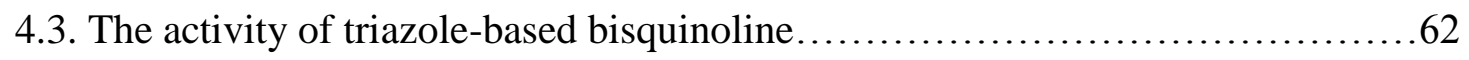

CHAPTER 5: Reversed chloroquines...............................................63

5.1. The 6 -aminoquinoline antimalarials......................................63

5.2. Fluoxetine as reversal agent.............................................64

5.3. Meta-substituted analogue of PL69 ..........................................66

CHAPTER 6: Summary and conclusion.........................................68 
CHAPTER 7: Experimental materials and methods

7.1. Instrumentation....................................................... 71

7.2. General synthetic procedures....................................... 71

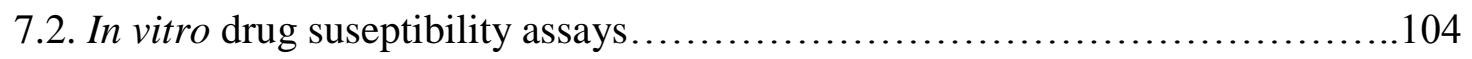

REFERENCES ........................................................ 106

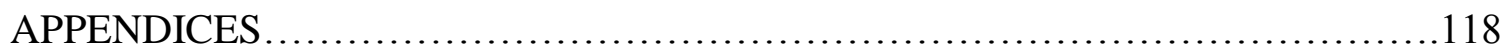

A. List of intermidiate compounds synthesized..............................118

B. List of target compounds synthesized.........................................121

C. Selected spectral and chromatography data................................ 127 


\section{LIST OF TABLES}

\section{CHAPTER 1}

Table 1.1. Clinical features and geographical distribution of Plasmodia species...........3

Table 1.2. Medications that should not be used for malaria chemoprophylaxis...........7

Table 1.3. Mutations in P. falciparum associated with resistance to antimalarial drugs...14

Table 1.4. Mutant forms of PfCRT and association of the K76T marker with chloroquine resistant $P$. falciparum from different geographic regions.

\section{CHAPTER 3}

Table 3.1. The first synthesized click compounds.............................41

Table 3.2. Para-substituted click compounds.................................42

Table 3.3. Structures of 10 piperazine-containing terminal alkynes.................45

Table 3.4. Structures of piperazinyl-triazoles................................47

\section{CHAPTER 4}

Table 4.1. The $\mathrm{IC}_{50}$ comparison of phenyl, pyridyl, and benzyl triazoles..............51

Table 4.2. The $\mathrm{IC}_{50}$ comparison of ortho-, meta-, and para-methoxy substitutions.......52

Table 4.3. Comparison of various electron-withdrawing groups $\ldots \ldots \ldots \ldots \ldots \ldots \ldots \ldots \ldots 5$

Table 4.4. Selected first generation click compounds with better activity than CQ......57

Table 4.5. Selected Piperazine containing click compounds having better activity than

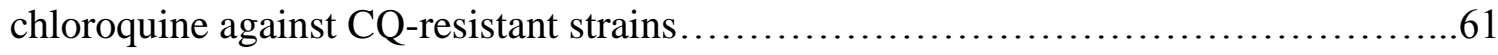

Table 4.6. The structure and activity of triazole-based bisquinoline..................62 


\section{LIST OF FIGURES}

\section{CHAPTER 1}

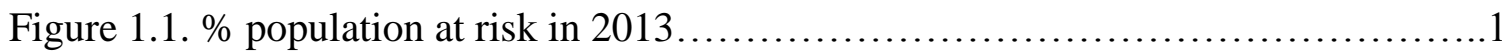

Figure 1.2. Life cycle of Plasmodia species.........................................

Figure 1.3. Currently available antimalarial drugs ................................. 10

Figure 1.4. Antimalarial drug candidates in clinical development.....................13

Figure 1.5. Approximate dates of introduction and treatment failure of antimalarial

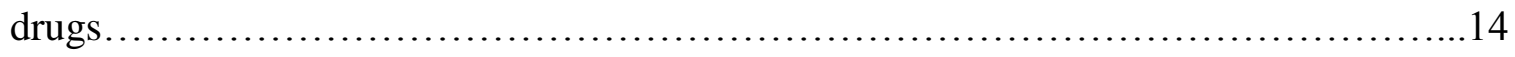

Figure 1.6. Mechanism of action of CQ and electron micrograph of the DV ............16

Figure 1.7. Pharmacophore of chloroquine reversal resistance.........................18

Figure 1.8. Structures of known CQ-resistance reversal agents used as

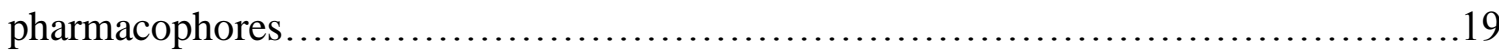

Figure 1.9. The hit (PL01) and the lead (PL69) RCQ's synthesized in Peyton lab........20

\section{CHAPTER 2}

Figure 2.1. Proposed catalytic cycle for the CuAAC reaction..........................26

Figure 2.2. Drugs based on 1,2,3-triazoles........................................29

Figure 2.3. Triazole-based anticancer molecules...................................30

Figure 2.4. Triazole-based antibacterial and antifungal molecules.......................31

Figure 2.5. Triazole-based anti-HIV hybrid molecule..................................31

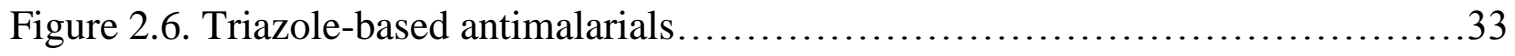

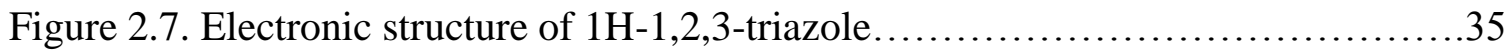


Figure 2.8. Structures, tautomerism, partial charges and dipole moments of the $1 \mathrm{H}-1,2,3-$

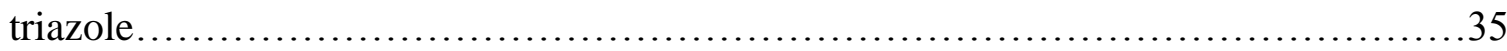

Figure 2.9. Disubstituted trans-amides and 1,2,3-triazoles as bioisosteres..............36

Figure 2.10. 1,2,3-Triazoles used as bioisosters of trans-amides.................... 37

\section{CHAPTER 4}

Figure 4.1. The effect of hetroatomic replacement and linker addition.................51

Figure 4.2. The effect of methoxy group substitution............................51

Figure 4.3. The effect of mono- and di-fluoro substitution........................52

Figure 4.4. Comparison of the $\mathrm{IC}_{50}$ values of para-methoxy, trifluoromethoxy and trifluoromethyl-phenyl substituted click compounds ........................53

Figure 4.5. The $\mathrm{IC}_{50}$ values of para-phenyl substituted electron-withdrawing groups.....54

Figure 4.6. The $\mathrm{IC}_{50}$ values comparison of para-halogen substituted triazoles...........54

Figure 4.7. Click compounds containing pharmacophore similar to the reversal agent...55

Figure 4.8. The activity of electron-donating groups substituted at the para position......58

Figure 4.9. The comparison of $\mathrm{IC}_{50}$ values of mono and dichloro-substituted triazoles...59

Figure 4.10. Triazole having methyl linker between piperazine and phenyl rings........59

Figure 4.11. The comparison of the selected first and second generation triazoles for similar substituents .60 


\section{LIST OF SCHEMES}

\section{CHAPTER 2}

Scheme 2.1. Click Chemistry - energetically highly favorable linking reactions.........23

Scheme 2.2. Synthesis of antitumor dehydropyrrolizidine analogue $\ldots \ldots \ldots \ldots \ldots \ldots \ldots .24$

Scheme 2.3. The 1,3-dipolar cycloaddition between azides and alkynes................24

\section{CHAPTER 3}

Scheme 3.1. Synthesis of starting material - azide analogue......................... 39

Scheme 3.2. General synthetic pathway of the first generation click compounds........40

Scheme 3.3. General synthetic pathway of para-substituted click compounds..........42

Scheme 3.4. Synthesis of PL423............................................ 44

Scheme 3.5. Synthesis of $\mathrm{p}$-phenyl piperazinyl substituted terminal alkynes...........45

Scheme 3.6. Synthesis of piperazine containing triazoles.............................46

Scheme 3.7. Synthesis of bisquinoline containing triazole..........................48

\section{CHAPTER 5}

Scheme 5.1. Synthesis of 6-aminoquinoline antimalarial, PL370 ..................63

Scheme 5.2. Synthesis of reversed chloroquine using fluoxetine as reversal agent........65

Scheme 5.3. Synthesis of m-substituted analogue of PL69...........................66 


\begin{tabular}{|c|c|}
\hline WHO & World health organization \\
\hline RDT & Rapid diagnostic test \\
\hline PCR & Polymerase chain reaction \\
\hline ELISA & Enzyme-linked immunosorbent assay \\
\hline MalERA & Malaria eradication research agenda \\
\hline DDT & Dichloro-diphenyl-trichloroethane \\
\hline IRS & Indoor residual spraying \\
\hline ITN & Insecticide treated nets \\
\hline GMM & Genetically modified mosquitoes \\
\hline SBET & Stand-by-emergency treatment \\
\hline G6PD & Glucose-6-phosphate dehydrogenase \\
\hline $\mathrm{ACT}$ & Artemisinin-based combination therapy \\
\hline SERCA & Sarco/endoplasmic reticulum $\mathrm{Ca}^{2+}$-ATPase \\
\hline SP & Sulfadoxine-pyrimethamine \\
\hline IV & Intravenous \\
\hline $\mathrm{RCQ}$ & Reversed chloroquines \\
\hline CQ & Chloroquine \\
\hline CQR & Chloroquine resistant \\
\hline CQS & Chloroquine sensitive \\
\hline
\end{tabular}


PfCRT Plasmodium falciparum chloroquine resistant transporter

PL Peyton lab

SC Subcutaneous

GI Gastro-intestinal

DV Digestive vacuole

RA Reversal agent

$\mathrm{IC}_{50} \quad$ Half maximal inhibitory concentration

CC Click chemistry

CuACC Copper-catalyzed alkyne azide cycloaddition

DBCO Dibenzcyclooctyl
ADMET Absorption, distribution, metabolism, excretion, and toxicity
MDR Multidrug resistance
DFO 1,8-Diazafluoren-9-one
p-TSA p-Toluenesulfonic acid
DIPEA Di-isopropylethylamine 


\section{CHAPTER 1: Malaria}

\subsection{Introduction and Epidemiology}

Malaria is a tropical infectious disease considered as one of the most prevalent and debilitating diseases affecting humans. ${ }^{1}$ There are 3.4 billion people at risk of malaria transmission in 106 countries and territories. The WHO estimates 198 million cases of malaria and an estimated 584,000 deaths, many of them are children living in subSaharan Africa where a child dies every minute. ${ }^{2}$ Malaria was eliminated from the United States in the early 1950's. However, $1500-2000$ malaria cases are reported every year in the US from recent travelers. ${ }^{3}$
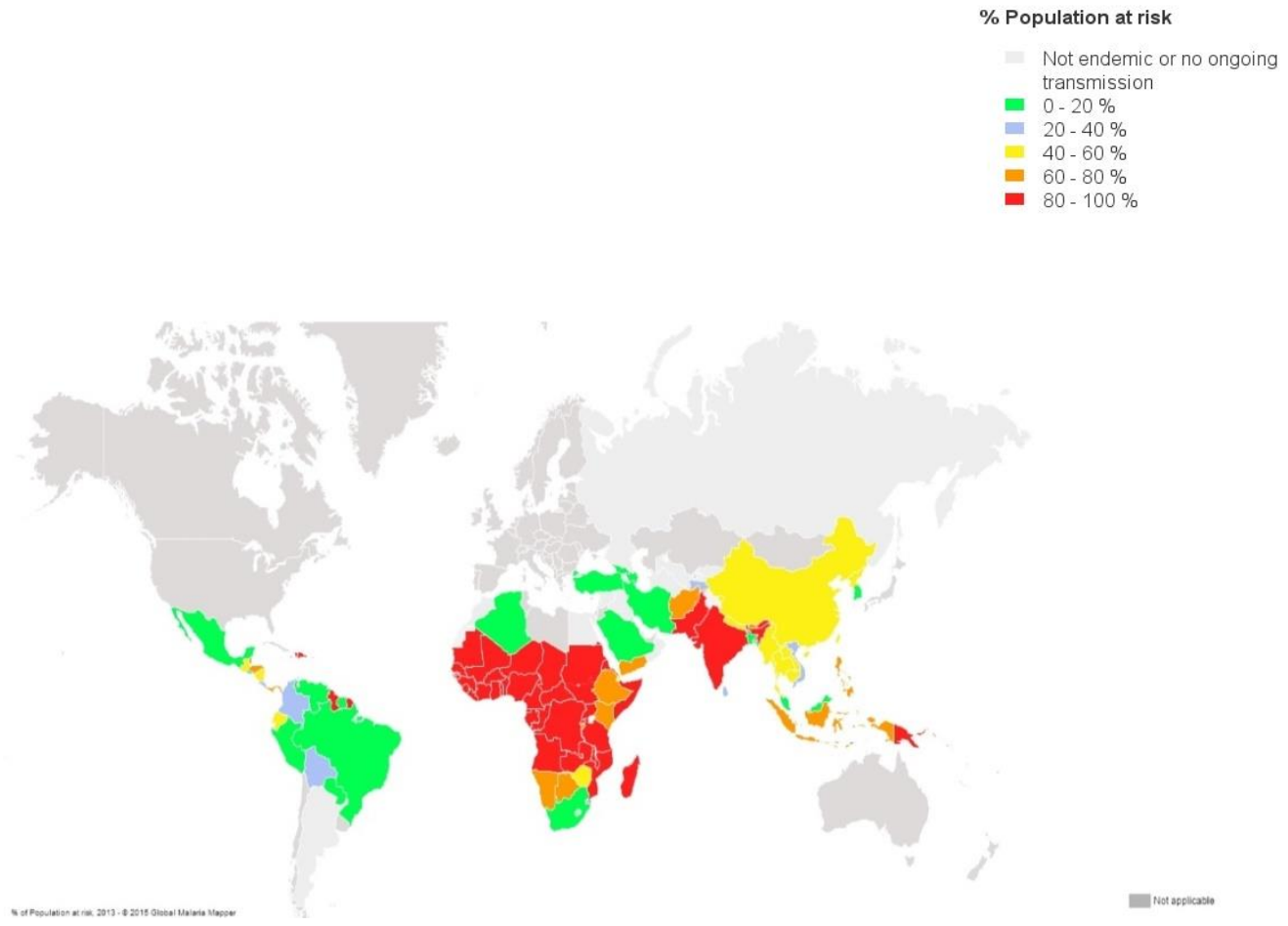

Figure 1.1. $\%$ population at risk in $2013^{2}$ 


\subsection{Cause and Transmission}

Malaria is caused by infection with protozoan parasites belonging to the genus Plasmodium transmitted by female Anopheles mosquitoes. ${ }^{4}$ Although over 200 species of Plasmodium genus are existing, only five affect humans: $P$. falciparum, $P$. vivax, $P$. ovale, P. malarie and P. knowlesi. ${ }^{5}$

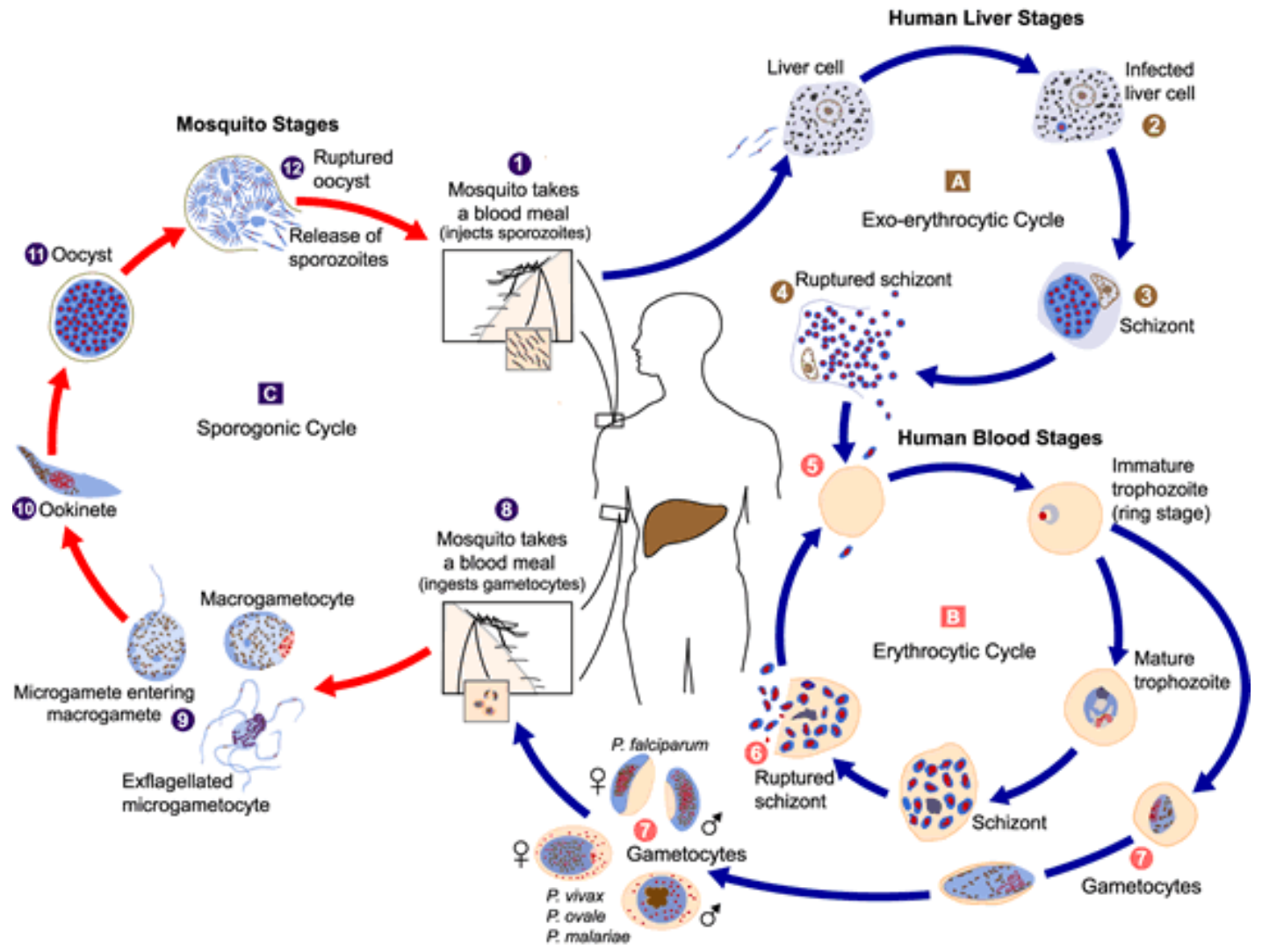

Figure 1.2. Life cycle of Plasmodia species $^{11}$

Plasmodium falciparum is the most virulent form which causes potentially fatal cerebral malaria. It's characterized by high levels of parasitaemia and is responsible for about 
$80 \%$ of human malaria worldwide. ${ }^{1,5}$ Relapse is common with $P$. vivax and ovale due to the dormant stage (hypnozoites) persisting in the liver and invading the blood stream in later years. While $P$. vivax and $P$. ovale selectively infect young cells, $P$. malariae parasitizes older cells. ${ }^{6} P$. knowlesi is considered as a parasite of monkeys that can cause fatal infections in humans. ${ }^{7}$

\begin{tabular}{|l|l|l|}
\hline Species & Clinical features & Endemic areas \\
\hline $\begin{array}{l}\text { Plasmodium } \\
\text { falciparum }\end{array}$ & $\begin{array}{l}\text { Tertian non-relapsing malignant } \\
\text { malaria }\end{array}$ & $\begin{array}{l}\text { Sub-Saharan Africa, Latin } \\
\text { America, South-East Asia }\end{array}$ \\
\hline $\begin{array}{l}\text { Plasmodium } \\
\text { vivax }\end{array}$ & $\begin{array}{l}\text { Tertian relapsing benign } \\
\text { malaria }\end{array}$ & $\begin{array}{l}\text { South-East Asia, Latin } \\
\text { America, Sub-Saharan Africa }\end{array}$ \\
\hline $\begin{array}{l}\text { Plasmodium } \\
\text { ovale }\end{array}$ & $\begin{array}{l}\text { Tertian relapsing benign } \\
\text { malaria }\end{array}$ & $\begin{array}{l}\text { South-East Asia, Pacific, East } \\
\text { Africa }\end{array}$ \\
\hline $\begin{array}{l}\text { Plasmodium } \\
\text { malariae }\end{array}$ & $\begin{array}{l}\text { Quartan non-relapsing benign } \\
\text { malaria }\end{array}$ & West Africa, Guyana, India \\
\hline $\begin{array}{l}\text { Plasmodium } \\
\text { knowlesi }\end{array}$ & $\begin{array}{l}\text { Quotidian, Severe malaria may } \\
\text { occur }\end{array}$ & South-East Asia \\
\hline \begin{tabular}{l} 
Table 1.1. Clinical features and geographical distribution of Plasmodia species $^{8}$ \\
\hline
\end{tabular}
\end{tabular}

The malaria parasite life cycle involves two hosts: human and mosquito. During a blood meal, a Plasmodium-infected female Anopheles mosquito inoculates sporozoites into the human host. Sporozoites infect liver cells and mature into schizonts, which rupture and release merozoites. At this stage they can also remain dormant as hypnozoites. ${ }^{9}$ After the initial replication in the liver, the parasites undergo asexual multiplication in the erythrocytes. Merozoites infect red blood cells. The ring stage trophozoites mature into schizonts, which rupture releasing merozoites. Some parasites differentiate into sexual erythrocytic stages (gametocytes). Blood stage parasites are responsible for the clinical manifestations of the disease. ${ }^{10}$ 
The gametocytes, male and female, are ingested by an Anopheles mosquito during a blood meal. While in the mosquito's stomach, the microgametes penetrate the macrogametes generating zygotes. The zygotes in turn become motile and elongated ookinetes which invade mosquito gut where they develop into oocysts. ${ }^{11}$ The oocytes give birth to sporozoites in the gut of a female mosquito. These migrate to the mosquito's salivary glands, and are injected into humans. Inoculation of the sporozoites into a new human host perpetuates the malaria life cycle. ${ }^{12}$

\subsection{Symptoms and Diagnosis}

Following an infective bite by female Anopheles mosquito, the infected person starts to show symptoms after 1 to 4 weeks. The most common symptoms of malaria include fever, chills, sweating, headaches, fatigue, nausea, and vomiting. ${ }^{13}$ In $P$. falciparum malaria, untreated patients present more pernicious manifestations such as cerebral malaria, hypoglycemia, acute renal failure, metabolic acidosis, severe anemia, and pulmonary edema. ${ }^{14}$ Severe anemia is a major cause of morbidity and mortality among children in the developing countries.

Microscopy is the basis for diagnosis of malaria providing information about the species and the density of Plasmodium. Polymerase chain reaction (PCR) is also used when the detection limits of parasites is below microscopy. ${ }^{15}$ Antigen-detecting RDT detects Plasmodium antigen by an antibody-antigen reaction on a nitrocellulose strip. ${ }^{16}$ Antibody could also be detected by ELISA after exposure to the parasites. Moreover, hemozoin, a 
by-product of Plasmodium metabolism, has been used to detect both the disease and the species via the absorbance of laser light at specific frequencies. ${ }^{17}$

\subsection{Treatment and Prevention}

The Malaria Eradication Research Agenda (malERA) addressed several issues in malaria elimination campaigns. It focuses on integrated research agenda which is essential in making pragmatic decision for shifting from control to elimination. ${ }^{18}$ The global malaria control strategy aims to halt the exacerbating situation of malaria by minimizing waste of resources and improving health services. ${ }^{19}$

Insect repellents could provide useful protection against malaria, especially in places where vector mosquitos bite early in the evening. ${ }^{20}$ Indoor residual spraying (IRS), mainly through the use of the insecticide DDT (dichloro-diphenyl-trichloroethane) has been an important component of malaria control. Despite attempts to ban DDT completely because of issues such as effect on preterm births and lactation duration, the compound continues to be used in parts of Asia and Africa. ${ }^{20,21}$

Vector control is also an essential component of prevention. ${ }^{21}$ Insecticide-treated nets (ITNs) have consistently shown reductions in overall child mortality and in episodes of clinical malaria. ${ }^{20}$ In areas of moderate or high transmission in Africa, deployment of pyrethroid insecticide-treated mosquito nets reduced all-cause mortality by roughly $20 \%$ in children younger than 5 years. ${ }^{21}$ ITNs are more beneficiary than IRS as they both protect the individual user against biting and kill some of the mosquitoes that try to bite. 
Deltamethrin and Permethrin are the most commonly used insecticides constituting about 60 and $22 \%$ of the global usage respectively. ${ }^{22}$

The genome of Anopheles gambiae, one of the most efficient vectors of malaria, has now been sequenced providing candidate genes in generating Genetically Modified Mosquitoes (GMM). ${ }^{24}$ This 20 -year old program uses site-specific gene recombination technologies to insert the antipathogen effector genes in the integration sites of the genome to develop A. gambie that are fully refractory to plasmodium. ${ }^{22}$

Drug chemoprophylaxis has also proved to be one of the most effective preventive strategy especially for travellers to malaria endemic areas. It is essential to emphasize that no chemoprophylactic regimen gives complete protection and must always be accompanied by primary protection such as ITN and insect repellants. The prophylaxis drug should be continued to be taken for at least 4 weeks after the last possible exposure to take into account for the pre-erythrocytic phase of the plasmodial cycle. ${ }^{8}$

Common antimalarials used as chemoprophylactic agents include chloroquine, proguanil, mefloquine, doxycycline, primaquine and tefenoquine. Proguanil in combination with chloroquine and atovaquone (Malorone) is also administered. Some antimalarial drugs that have well established therapeutic roles have no rational use as malaria chemotherapeutic agents (Table 2). Although chloroquine is less useful as chemoprophylaxis in most places, it is still used in Central America and Hispaniola. In the US, mefloquine (1989), doxycycline (1992) and atovaquone/proguanil (2001) are the three currently approved drugs for malaria prevention. 8,25 


\begin{tabular}{|l|l|}
\hline Antimalarial drug & $\begin{array}{l}\text { Severe adverse event or contraindication } \\
\text { observed }\end{array}$ \\
\hline Amodiaquine & agranulocytosis and hepatotoxicity \\
\hline Halofantrine & cardiac dysrhythmias \\
\hline Pyrimethamine-dapsone & Agranulocytosis \\
\hline $\begin{array}{l}\text { Pyrimethamine- } \\
\text { sulfadoxine }\end{array}$ & $\begin{array}{l}\text { severe skin reactions (e.g. Stevens-Johnson } \\
\text { syndrome) }\end{array}$ \\
\hline Quinine & long-term use predisposes to blackwater fever \\
\hline $\begin{array}{l}\text { qinghaosu derivatives } \\
\text { (i.e. artesunate) }\end{array}$ & $\begin{array}{l}\text { severe CNS lesions in animal studies in long-term } \\
\text { use of these short-acting drugs }\end{array}$ \\
\hline
\end{tabular}

Table 1.2. Medications that should not be used for malaria chemoprophylaxis

The WHO recommends occupational and long-term travellers to carry Stand-By Emergency Treatment (SBET) drugs for self treatment when medical care is not accessible within 24 hours from onset of exposure and symptoms. Combination drugs used for uncomplicated $P$. falciparum malaria such as artemether/lumefantrine, atovaquone-proguanil, quinine plus doxycycline or clindamycin can be used as SBET drugs. $^{8}$

Almost two decades have been spent on development of malaria vaccines. So far, most efforts have been put in developing pre-erythrocytic stage vaccines designed to destroy infected hepatocytes or prevent their invasion by sporozoites. ${ }^{20}$ RTS,S/AS01 is a hybrid molecule in which the circumsporozoite protein of $P$. falciparum is expressed with hepatitis-B surface antigen (HBsAg) in yeast and boosted with the potent ASO adjuvant. $^{21}$

In coincidence with World Malaria Day 2015, the RTS,S Clinical Trials Partnership reported final results of a Phase 3 trial of the RTS,S/AS01 vaccine which were conducted in seven countries in Africa. After 38 and 48 months, the results indicated 25.9 and 
$36.3 \%$ protection in children at 6-12 weeks and 5-7 months respectively when 3 doses were given at $0,1,2$ with a booster at 20 months or a control vaccine. ${ }^{26}$

Moreover, various medicinal plants are reported to possess insect-repellent activity against mosquitoes including Azadirachta indica, Lantana camara, Vitex negundo, Mentha piperita, Tagetes minuta, Eucalyptus and Cymbopogon species. ${ }^{23}$ In some definite epidemiological situations, environmental management activies comprising drainage of mosquitoes breeding sites, house design improvements and utilising larvivorous fish have proved to be effective. ${ }^{20}$

\subsection{Antimalarial Chemotherapy}

When malaria prevention fails and a person is infected by the parasite, several treatment options are available. The treatment depends on the type the Plasmodium species, the stage of the parasite, the mechanism of action and the half life of the drug.

Quinine was the first natural antimalarial extracted from the bark of cinchona tree in Peru around the $17^{\text {th }}$ century. It was the pioneer drug and has been used for more than two centuries until its resistance emerged. ${ }^{27}$ In addition, the common side effect symptoms of cinchonism associated with it decreased its use. Because of resistance, quinine is taken in combination with secondary agents such as doxycycline, clindamycin or SP. Although its sterioisomer, quinidine, could be given IV for $P$. falciparum malaria, it is basically indicated as anti-arrhythmic. ${ }^{29}$

The 4-aminoquinolines are an important class of antimalarials which comprises of chloroquine, amodiaquine and piperaquine. ${ }^{27}$ Chloroquine is one of the classic drugs 
which became a mainstay for malaria treatment in the mid- $20^{\text {th }}$ century. Chloroquine and amodiaquine have blood schizontocidal effects against asexual stages of the parasite in blood. ${ }^{28}$ Despite the reported cases of hepatotoxicity and agranulocytosis for amodiaquine, the lack of new drugs for drug-resistant malaria made it attractive. ${ }^{29}$

Another important class are the 4-methanoquinolines including mefloquine, halofantrine and lumifantrine. ${ }^{27}$ In addition to neuropsychiatric side effects, drug resistance in southeast asia has limited the use of mefloquine. Halofantrine is another aminoalcohol effective for treating chloroquine-resistant malaria, but cardiotoxicity is associated with its use. Lumefantrine is a racemic fluorene derivative which is only available in coformulation with artemether. ${ }^{29}$

Primaquine, pamaquine and bulaquine belong to a class of 8 -aminoquinolines. ${ }^{27}$ Primaquine is one of the few drugs effective against both gametocytes of $P$. falciparum and hypnozites of P. vivax and P. ovale. However, its short half-life (6 hrs) makes it contraindicated in patients with G6PD deficiency, because it has to be taken for two weeks to overcome relapse in $P$. ovale and vivax infections. ${ }^{28}$

Artemisinin belongs to a class of sesquiterterpene lactones, extracted from a sweet woodworm Artemisia annua. ${ }^{29}$ Artemisinin derivatives such as artemether, artesunate and arteether have been used recently in China and SE Asia for the management of malaria. Their high gametocidal effect and low resistance profile made them the mainstay combination therapy. ${ }^{28}$ Unfortunately artemisinin can not be used alone due to its short half-life, and hence the WHO highly recommends administration of ACTs. It has been 
suggested that these endoperoxides act by damaging Sarco-Endoplasmic Reticulum $\mathrm{Ca}^{2+}$ ATPase (SERCA). ${ }^{29}$<smiles>CCN(CC)CCCC(C)Nc1ccnc2cc(Cl)ccc12</smiles><smiles>COc1cc(NC(C)CCCN)c2ncccc2c1</smiles><smiles>OC(c1cc(C(F)(F)F)nc2c(C(F)(F)F)cccc12)C1CCCCN1</smiles>

Mefloquine
Amodiaquine
Primaquine

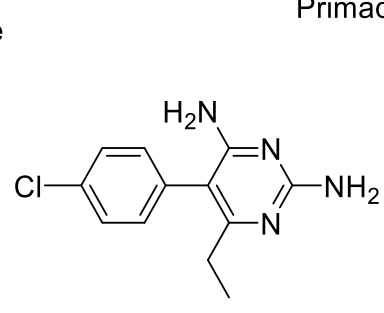<smiles>CC(C)NC(=N)NC(=N)Nc1ccc(Cl)cc1</smiles>

Pyrimethamine<smiles>CCCCN(CCCC)CCC(O)c1cc2cc(Cl)cc(Cl)c2c2cc(C(F)(F)F)ccc12</smiles>

Halofantrine

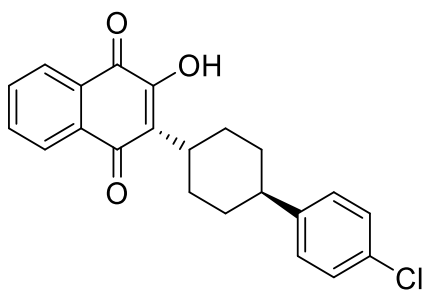

Atovaquone

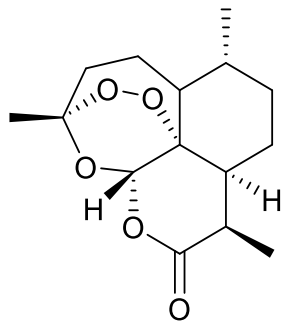

Artemisinin

Figure 1.3. Currently available antimalarial drugs

Atovaquone is a hydroxy-naphthoquinone which acts by collapsing mitochondrial membrane potential of the parasite. ${ }^{27}$ It's usually used for treatment and prevention of chloroquine-resistant $P$. falciparum in combination with proguanil (Malarone). Proguanil is a biguanide antifolate that synergistically acts by reducing the concentration of atovaquone needed. $^{29}$

Sulfadoxime and pyrimethamine are antifolate inhibitors which inhibit DNA synthesis of the parasite by specifically targeting dihydropteroate synthase and dihydrofolate 
reductase enzymes. SP (Fansidar) is very effective when administered in combination with amodiaquine. ${ }^{29}$ Dapsone is another sulfone drug used with chlorproguanil (lapdap), although withdrawn due to its hemolytic toxicity. Antibiotics are also recommended for use in quinoline-resistant strains. Tetracyclines (tetracycline \& doxycycline) and macrolides (clindamycin \& azithromycin) act by inhibiting RNA synthesis. They are very beneficial in combination therapy with quinine. ${ }^{31}$

Research and development of new and recycled antimalarial drugs is still in progress, and many drugs are in their preclinical and clinical phases. 4-aminoquinoline drugs such as AQ-13 and N-tert-butyl-isoquine (GSK369796) are analogues of chloroquine and amodiaquine which are in Phase II clinical and Preclinical trials respectively. AQ-13 is being studied for uncomplicated $P$. falciparum malaria but there is a concern of cross resistance with chloroquine. ${ }^{33} \mathrm{~N}$-tert-butyl-isoquine is highly effective and possesses better overall preclinical safety profile than chloroquine or amodiaquine. ${ }^{34}$

Tefenoquine and NPC-1161B are 8-aminoquinolines under inverstigation for the treatment of the hypnozoite stages of $P$. vivax and $P$. ovale that are responsible for relapse of these malaria species. Tefenoquine has an advantage over primaquine in that it is long acting (2-3 weeks) for treating liver stages of $P$. vivax. Tafenoquine is currently in late stage development as an anti-malarial prophylactic agent, and NPC-1161B is in late preclinical development. ${ }^{35}$

The disadvantages of semisynthetic artemisinin derivatives are their short half-lives, dependence on plant source for starting material, and alarming reports of ACT treatment failures which call for a need for new analogues to this class of antimalarials. OZ277 
(Arterolane) was the first synthetic ozonide to be evaluated clinically and is now launched in India in combination with piperaquine, and has obtained regulatory approval to introduce in seven African countries.

OZ439 is another improved synthetic ozonide candidate designed to provide a singledose oral cure in humans. It has successfully completed Phase I clinical trials and is currently undergoing Phase IIb trials in malaria patients in combination with piperaquine. When compared to OZ277 and other former endoperoxides, OZ439 is active against all asexual erythrocytic stages of $P$. falciparum and exhibits a substantial increase in the pharmacokinetic half-life. ${ }^{36}$

Mutations on dihydrofolate reductase enzyme compromised the efficacy of antifolate drugs. Research in developing new antifolates such as P65, P218, and WR99210 is inadvance. P218 has proven to potently inhibit both wild-type and clinically relevant mutated forms of Plasmodium falciparum. Its suitable pharmacologic and safety profile made it to be an oral antimalarial candidate among this class. ${ }^{37}$ KAE609 (Cipargamin) is a first-in-class agent with a new mechanism of action by inhibiting pfATP4 $\left(\mathrm{Ca}^{2+}-\right.$ ATPase). This spiroindolone showed a rapid antimalarial activity in phase II clinical trial for the treatment of uncomplicated $P$. falciparum and vivax malaria. ${ }^{38}$ 
<smiles>CCN(CC)CCCNc1ccnc2cc(Cl)ccc12</smiles>

AQ-13<smiles>Cc1cc(N[C@H](C)CCCN)c2nccc(C)c2c1Oc1ccc(Cl)c(Cl)c1</smiles>

NPC-1161B<smiles>CC1(C)N=C(N)N=C(N)N1</smiles>

WR99210<smiles>CCN(CC)Cc1ccc(Nc2ccnc3cc(Cl)ccc23)cc1O</smiles>

$\mathrm{N}$-Tertbutyl Isoquine<smiles>Cc1nc(N)nc(N)c1OCCCOc1cc(Cl)c(Cl)cc1Cl</smiles>

P65<smiles>C[C@]1(C(=O)Nc2ccc(Cl)cc2)NCCc2c1[nH]c1cc(Cl)c(F)cc21</smiles>

KAE609<smiles>Cc1cc(C)c2c(Oc3cccc(C(F)(F)F)c3)c(C)cc(NC(C)CCCN)c2n1</smiles>

Tefenoquine<smiles>CCc1nc(N)nc(N)c1OCCCOc1ccccc1CCC(=O)O</smiles>

P218

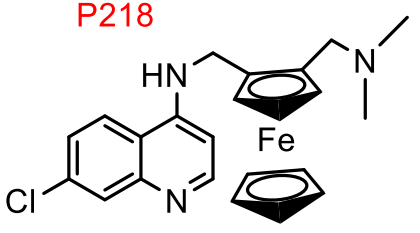

Ferroquine

Figure 1.4. Antimalarial drug candidates in clinical development

\subsection{Resistance to Antimalarial Drugs}

The plasmodium parasite developed acquired resistance to antimalarial drugs. The type of the resistance varies with the species, the strain, and the drug used. Many factors account for the development and spread of resistance including drug-use patterns, characteristics of the drug, host factors, parasite characteristics, vector, and environmental factors. ${ }^{39}$

Drug resistance to several novel antimalarial drugs has been reported when used as monotherapy and combination drugs. Plasmodium falciparum is the main concern and cause of resistance among the five species. Chloroquine resistance to $P$. vivax is largely concentrated in Indonesia and Papua New Guinea. Chloroquine retained adequate efficacy against $P$. ovale and $P$. malariae, but delayed parasite clearance times is 
observed. ${ }^{40}$ There are recent reports of treatment failure and clinical resistance to artemisinin-based therapy in western Cambodia. ${ }^{41}$

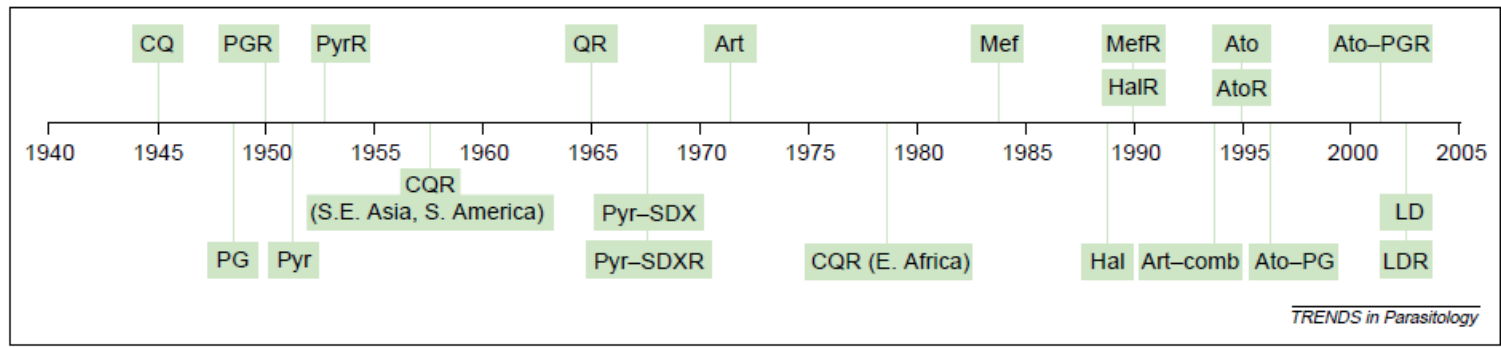

Figure 1.5. Approximate dates of introduction and treatment failure of antimalarial drugs [Abbreviations: Chloroquine (CQ), Atovaquine-Proguanil (PG), Pyrimethamine (Pyr), Quinine (Q), Sulfadoxine (SDX), Artimisinin and derivatives (Art), Mefloquine (Mef), Halofantrine (Hal), Atovaquone (Ato) , LapDap: Chlorproguanil-Dapsone (LD), Resistance (R), Combinations (Comb)]. ${ }^{42}$

Genetic mutations in P. falciparum strains have been linked with phenotypes of clinical resistance and putative markers have emerged and reported. ${ }^{39}$

\begin{tabular}{|l|l|l|l|}
\hline Gene & Product & Genetic Determinant & Drug \\
\hline$p f c r t$ & Transporter & Thr76 & Chloroquine \\
\hline$p f m d r ~ 1$ & Transporter & Tyr86 & $\begin{array}{l}\text { Chloroquine, mefloquine, quinine, } \\
\text { dihydroartemisinin, artesunate }\end{array}$ \\
\hline$d h p s$ & $\begin{array}{l}\text { Dihydropteroate } \\
\text { Synthetase }\end{array}$ & $\begin{array}{l}\text { Gly437, Glu540, } \\
\text { Gly581 }\end{array}$ & Sulfadoxine \\
\hline$d h f r$ & $\begin{array}{l}\text { Dihydrofolate } \\
\text { Reductase }\end{array}$ & $\begin{array}{l}\text { Asn108, Arg59, } \\
\text { Ile51, Leu164 }\end{array}$ & Pyrimethamine \\
\hline cytb & Cytochrome b & Ser268 & Atovaquone \\
\hline
\end{tabular}

Table 1.3. Mutations in P. falciparum associated with resistance to antimalarial drugs 39

In order to counter drug resistance and delay the emergence of more resistance, many combination therapies have been adapted. The drugs to be used in combined therapies might require to have separate mechanisms of action against same stage of the parasite. Artemisinin derivatives along with other antimalarial classes present effort towards 
achieving such therapeutic level. ${ }^{39}$ Current combination regimens recommended by the WHO include artemether-lumefantrine, artesunate-amodiaquine, artesunate-mefloquine, and artesunate-SP. ${ }^{31}$

\subsection{Reversed Chloroquines}

Chloroquine (Resochin) was first synthesized in 1934 by a German chemist, Hans Andersag, by modifying mepacrine, replacing the acridine ring with a quinoline ring. ${ }^{43}$ Chloroquine is a weak base containing a side-chain diethylamine nitrogen $(\mathrm{pKa}=10.2)$ and a quinoline ring nitrogen $(\mathrm{pKa}=8.1)$. It is administered as a racemic mixture of two enantiomers of which the (+)-CQ enantiomer is more potent against CQ-resistant strains of $P$. falciparum than the (-)-chloroquine enantiomer. ${ }^{45}$ Chloroquine is indicated for treatment and prevention of acute uncomplicated malaria. ${ }^{47}$

Chloroquine could be administered in oral, subcutaneous, intramuscular and rectal routes. When taken orally, CQ is rapidly absorbed from GI tract with bioavailability of 75-

$80 \% .{ }^{45}$ It has an onset of action of 1-2 hrs and half-life of $3-6$ days. ${ }^{45} \mathrm{CQ}$ is metabolized in liver by CYP3A, CYP2C8, and CYP2D6 enzymes to mono-desethyl CQ (30-40\%) and bisdesethyl CQ (5-10\%). ${ }^{45}$ The CQ side chain is further dealkylated to form 7-chloro-4aminoquinoline. About $70 \%$ of the ingested drug is excreted unchanged in urine. ${ }^{45}$

CQ targets the biochemical pathway in the acidic digestive vacoule (DV) of $P$. falciparum. Heme released during metabolism of hemoglobin biocrystallizes to inert hemozoin by the Plasmodium parasite. CQ accumulates in the DV and blocks heme 
biocrystallization to hemozoin by forming cytotoxic CQ-heme complexes and other mechanisms that kill the parasites by making the cell-membrane permeable. ${ }^{46}$

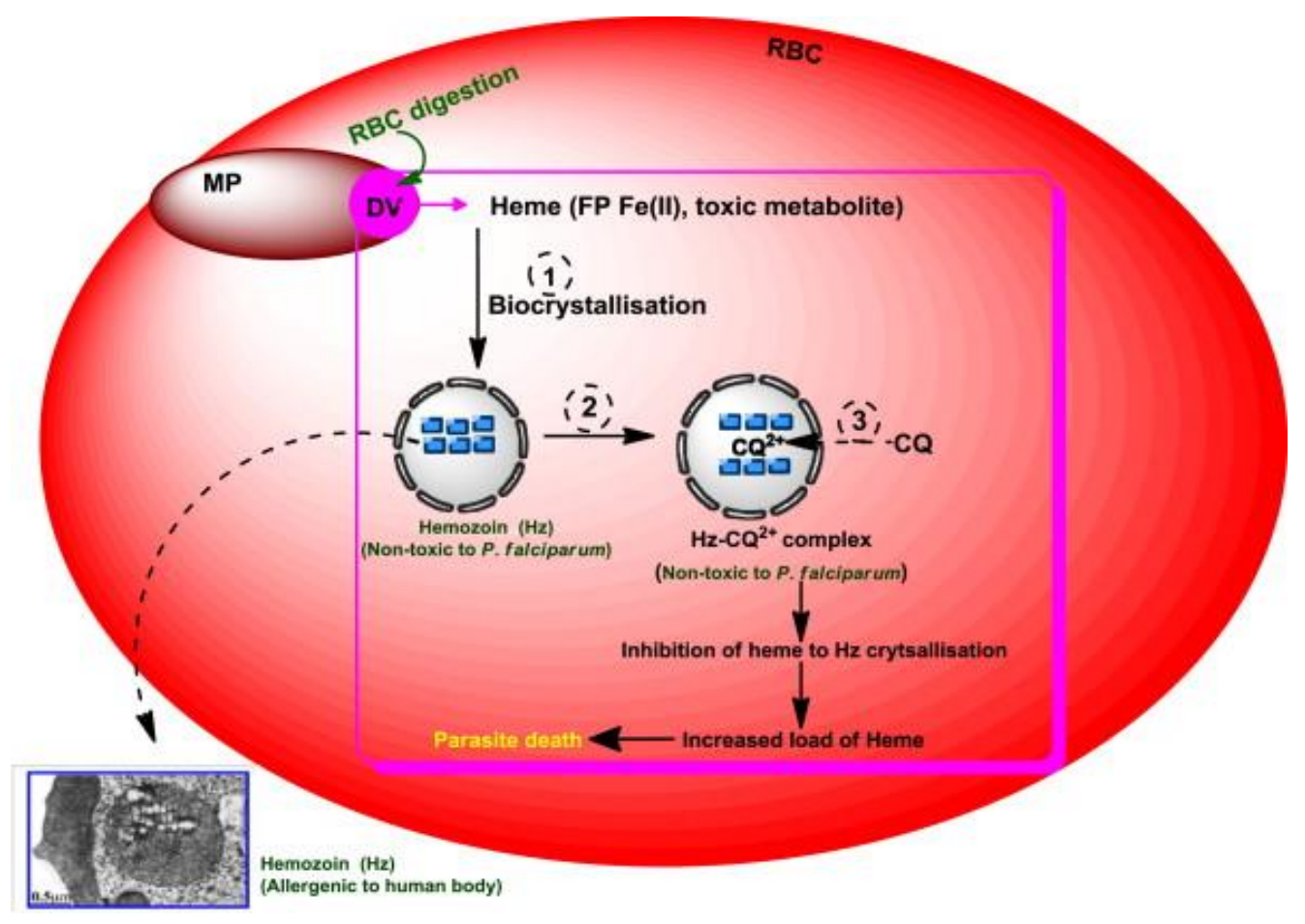

Figure 1.6. Mechanism of action of $\mathrm{CQ}$ and electron micrograph of the $\mathrm{DV}^{48}$

In the DV of Plasmodium falciparum $(\mathrm{pH}=5.5), \mathrm{CQ}$ is trapped at high concentration in its doubly protonated and membrane-impermeable form. ${ }^{47}$ The CQ-resistant strain accumulates 4-10 times less CQ than CQ-sensitive strains of $P$. falciparum, thus the intracellular CQ concentration will be less toxic to the parasite. ${ }^{46}$

Chloroquine is effective, cheap, and safe to children and pregnant women. It has been one of the most successful antimalarials ever developed and used as the most reliable firstline prophylaxis for 40 years. The first cases of resistance were reported from South America in 1961. The resistance to CQ is linked to mutation in the DV membrane protein 
of Plasmodium falciparum chloroquine resistant transporter (PfCRT). ${ }^{44}$ The change from lysine $(\mathrm{K})$ to threonine $(\mathrm{T})$ in the transmembrane domain of PfCRT appears to be required for the resistance. ${ }^{49}$

\begin{tabular}{|c|c|c|c|c|c|c|c|c|c|c|}
\hline \multirow{2}{*}{ Parasite type and origin } & \multicolumn{10}{|c|}{ PfCRT position and encoded aminoacid } \\
\hline & 72 & 74 & 75 & 76 & 97 & 220 & 271 & 326 & 356 & 371 \\
\hline \multicolumn{11}{|l|}{ Chloroquine sensitive } \\
\hline Wild type & $\mathrm{C}$ & $\mathrm{M}$ & $\mathrm{N}$ & $\mathrm{K}$ & $\mathrm{H}$ & A & $\mathrm{Q}$ & $\mathrm{N}$ & $\mathrm{I}$ & $\mathrm{R}$ \\
\hline 106/1 (reverant) & $\mathrm{C}$ & $\mathrm{I}$ & E & $\mathrm{K}$ & $\mathrm{H}$ & $\mathrm{S}$ & $\mathrm{E}$ & $\mathrm{S}$ & I & I \\
\hline \multicolumn{11}{|l|}{ Chloroquine resistant } \\
\hline Southeast Asia \& Africa, type E1a & $\mathrm{C}$ & I & E & $\mathrm{T}$ & $\mathrm{H}$ & $\mathrm{S}$ & $\mathrm{E}$ & $\mathrm{S}$ & $\mathrm{T}$ & I \\
\hline Southeast Asia \& Africa, type E1b & $\mathrm{C}$ & $\mathrm{I}$ & $\mathrm{E}$ & $\mathrm{T}$ & $\mathrm{H}$ & $\mathrm{S}$ & $\mathrm{E}$ & $\mathrm{S}$ & I & I \\
\hline Papua New Guinea, type P1 & $\mathrm{S}$ & $\mathrm{M}$ & $\mathrm{N}$ & $\mathrm{T}$ & $\mathrm{H}$ & $\mathrm{S}$ & Q & $\mathrm{D}$ & $\mathrm{L}$ & $\mathrm{R}$ \\
\hline South America, type W1a & $\mathrm{S}$ & $\mathrm{M}$ & $\mathrm{N}$ & $\mathrm{T}$ & $\mathrm{H}$ & $\mathrm{S}$ & $\mathrm{Q}$ & $\mathrm{D}$ & $\mathrm{L}$ & $\mathrm{R}$ \\
\hline South America, type W1b & $\mathrm{C}$ & $\mathrm{M}$ & $\mathrm{N}$ & $\mathrm{T}$ & $\mathrm{H}$ & $\mathrm{S}$ & $\mathrm{Q}$ & $\mathrm{D}$ & $\mathrm{L}$ & $\mathrm{R}$ \\
\hline South America, type W2 & $\mathrm{C}$ & $\mathrm{M}$ & $\mathrm{E}$ & $\mathrm{T}$ & Q & $\mathrm{S}$ & Q & $\mathrm{N}$ & I & $\mathrm{T}$ \\
\hline
\end{tabular}

Table 1.4. Mutant forms of PfCRT and association of the K76T marker with chloroquine resistant $P$. falciparum from different geographic regions ${ }^{50}$

Several reversal agents or chemosentisezers that reverse the resistance by inhibiting the efflux of chloroquine via membrane transporters of the DV of Plasmodium falciparum resistant strain have been reported. Verapamil and two other calcium channel blockers, vinblastine and daunomycin, are among the first drugs reported that slowed the release and increased the accumulation of chloroquine by resistant $P$. falciparum. ${ }^{52}$ Subsequently the reversal effect of tricyclic antidepressant, desipramine, and selective serotonin re-uptake inhibitor (SSRI), fluoxetine, were reported. ${ }^{53,54}$ Fluoxetine showed an increased reversal activity than verapamil when tested against CQ-resistant W2 clone of P. falciparum. $^{54}$

Antihistamines such as chlorpheniramine (racemic) and promethazine also showed reversal of chloroquine resistance in vitro against CQ-resistant $P$. falciparum. ${ }^{55,56}$ 
Combination of chemosentisizers had also displayed an additive effect in potentiating CQ accumulation in the DV of the resistant parasite ${ }^{57}$ The antimalarial drug, primaquine, also has a synergic activity with chloroquine and it blocks PfCRT. ${ }^{58}$ It was implicated by recent study that the mutant PfCRT uses reversal agents such as verapamil, chlorpheniramine, desipramine, prometazine, fluoxetine and primaquine as substrates. ${ }^{59}$

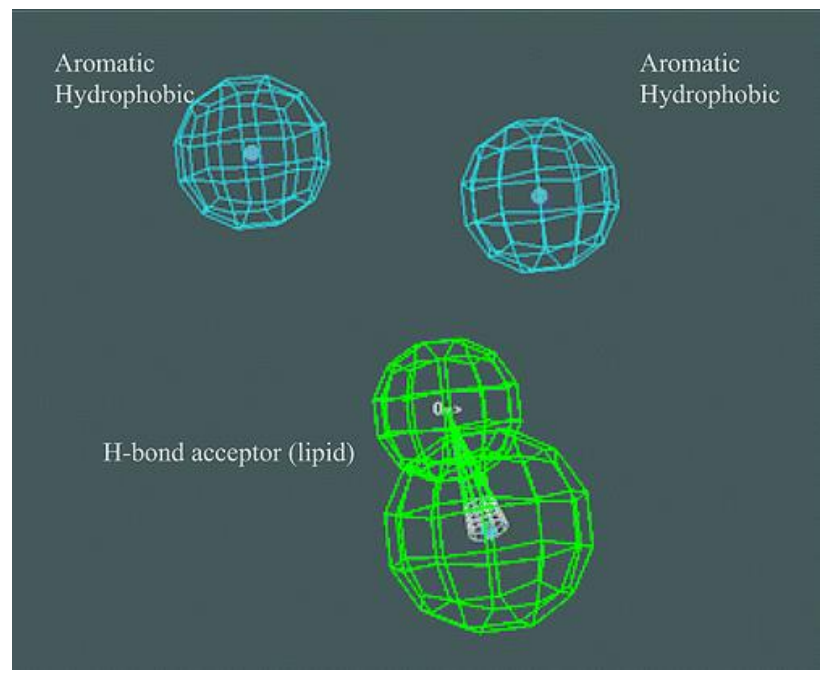

Figure 1.7. Pharmacophore of chloroquine reversal resistance ${ }^{60}$

Bhattacharjee et al. have developed a pharmacophore for reversal agents. ${ }^{60}$ The pharmacophore has a general structure of two aromatic hydrophobic groups and a hydrogen bond acceptor, preferably at a side chain nitrogen atom. The class of drugs which qualify for this pharmacophore include calcium channel blockers, antihistamines, tricyclic antidepressants and selective serotonin reuptake inhibitors (SSRI's). 
<smiles>CN1CCC(=C2c3ccccc3C=Cc3ccccc32)CC1</smiles>

Cyproheptadine<smiles>CN1CCC(=C2c3ccccc3C(=O)c3ccccc32)CC1</smiles>

Ketotifen<smiles>CN1CCC(=C2c3ccccc3CCc3cccnc32)CC1</smiles><smiles>CN(C)CCCN1c2ccccc2CCc2ccccc21</smiles><smiles>CC(CN1c2ccccc2Sc2ccccc21)N(C)C</smiles>

Azatadine

Imipramine

Promethazine<smiles>CN(C)CCC(c1ccc(Cl)cc1)C1CC=CC=N1</smiles><smiles>CNCCC(Oc1ccc(C(F)(F)F)cc1)c1ccccc1</smiles><smiles>CCc1ccccc1CO</smiles><smiles>O=C(CCCN1CCC(O)(c2ccc(Cl)cc2)CC1)c1ccc(F)cc1</smiles><smiles>CCOC(=O)C1=C(COCCN)NC(C)=C(C(OC)OCC)C1c1ccccc1Cl</smiles><smiles>CN(C)CCCC1(c2ccc(F)cc2)OCc2cc(C#N)ccc21</smiles>

Citalopram

Figure 1.8. Structures of known CQ-resistance reversal agents used as pharmacophores

To circumvent chloroquine resistance, reversed chloroquines were designed in Peyton lab. These are hybrid drugs comprising quinoline nucleus and reversal agent moiety. In earlier studies, the tricyclic antidrepressant drug, imipramine, showed the highest potency when tested for its CQ resistance reversal effect against W2 clone of $P$. falciparum. ${ }^{61}$ The first hybrid molecule, PL01, was synthesized by linking chloroquine moiety and imipramine as a RA. The hybrid analogue was found to be very effective against both CQ-sensitive and CQ-resistant strains of $P$. falciparum when compared to chloroquine. ${ }^{62}$ 
Modifications were made to PL01 to increase the oral availability. As a result a lead antimalarial drug candidate, PL69, was developed. It was found to be effective for CQresistant malaria in vitro. The $\mathrm{IC}_{50}$ values of PL69 against D6, Dd2, and 7G8 strains of $P$ falciparum were $0.9,1.6$, and $1.8 \mathrm{nM}$, when compared to CQ values of $6.9,102$, and 106 nM. PL69 was also orally available in a mouse model of malaria. In vivo, it cured mice infected with $P$. berghei at $<64 \mathrm{mg} / \mathrm{kg} /$ day, which is equimolar dose with of chloroquine. ${ }^{63}$

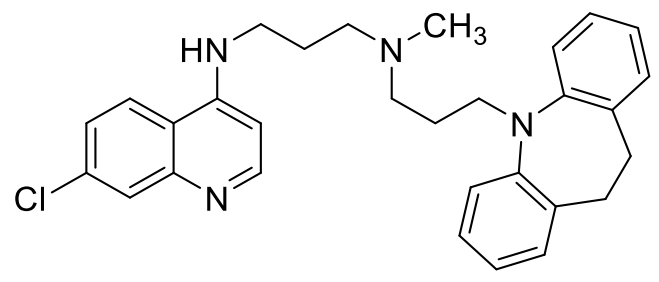

$$
\text { PL01 }
$$<smiles>Clc1ccc2c(NCCCN3CCC(NC(c4ccccn4)c4ccccn4)CC3)ccnc2c1</smiles>

PL69

Figure 1.9. The hit (PL01) and the lead (PL69) RCQ's synthesized in Peyton lab

Moreover, the mechanism of action was indicated to be similar to $\mathrm{CQ}$, by inhibiting the formation of hemozoin. PL69 (DM1157) is now in late-stage preclinical studies by DesignMedix. This lead RCQ candidate has physico-chemical features that makes it a favourable partner drug for antimalarial combination therapy. The drug discovery research is still on progress to furnish more back-up drugs for the pipeline. ${ }^{64}$ 


\section{CHAPTER 2: Click Chemistry}

\subsection{Introduction}

Nature's giant molecules are constructed from a small building blocks by few types of reactions for connecting them together. Biological macromolecules such as polysaccharides, proteins and nucleic acids are all condensation polymers of small subunits formed by carbon-heteroatom bonds. Following Mother Nature's strategy, Sharpless, Kolb, and Finn identified a group of reactions and developed an approach called 'Click Chemistry' in 2001. ${ }^{65}$ The main objective of click chemistry was to develop an array of selective, powerful and modular blocks which are reliable and have wide application. $^{66}$

Sharpless and coworkers have set criteria that a process must meet to fulfill these reactions: "The reaction must be modular, wide in scope, give very high yields, generate only inoffensive by-products that can be removed by non-cromatographic methods, and be stereospecific (but not necessarily enantioselective). The required process characteristics include simple reaction conditions, readily available starting materials and reagents, the use of no solvents or a solvent that is benign (such as water) or easily removed, and simple product isolation.", 66,67

Finn and Fokin have developed common attributes of click reactions that many click compounds are derived from alkenes and alkynes, and that the bond is formed between carbon and heteroatom (mostly $\mathrm{N}, \mathrm{O} \& \mathrm{~S}$ ). In addtion click reactions are strongly exothermic and are usually either fusion or condensation processes. Moreover, many 
click reactions are highly tolerant of water. In point of fact, they are often accelerated by the presence of water. ${ }^{68}$

\subsection{Types of click reactions}

There are mainly four types of click reactions that use olefins and acetylenes as their carbon framework for forming carbon-heteroatom bond. These reactions include:

- Cycloaddition reactions: for example hetero-Diels-Alder and 1,3-dipolar cycloadditions

- Nucleophilic ring-opening on strained heterocyclic electrophiles including epoxides, aziridines, cyclic sulfates \& sulfamidates and aziridinium \& episulfonium ions ${ }^{69}$

- Non-aldol carbonyl chemistry including formation of oxime ethers, hydrazones and aromatic heterocycles

- Addition to carbon-carbon multiple bonds such as epoxidation, dihydroxylation, aziridination, and nitrosyl and sulfenyl halide additions ${ }^{70}$

\subsection{Huigsen 1,3-Cycloaddition reactions}

The potential and the mechanism of 1,3-dipolar cycloaddition reaction between alkynes and azides to form 1,2,3-triazoles was unveilled by Huisgen et al. in the 1960 s. $^{71}$ However, the reaction was not utilized to its full extent until the copper(I)-catalyzed Azide-Alkyne cycloaddition (CuAAC) version reaction is discovered. ${ }^{72}$ 


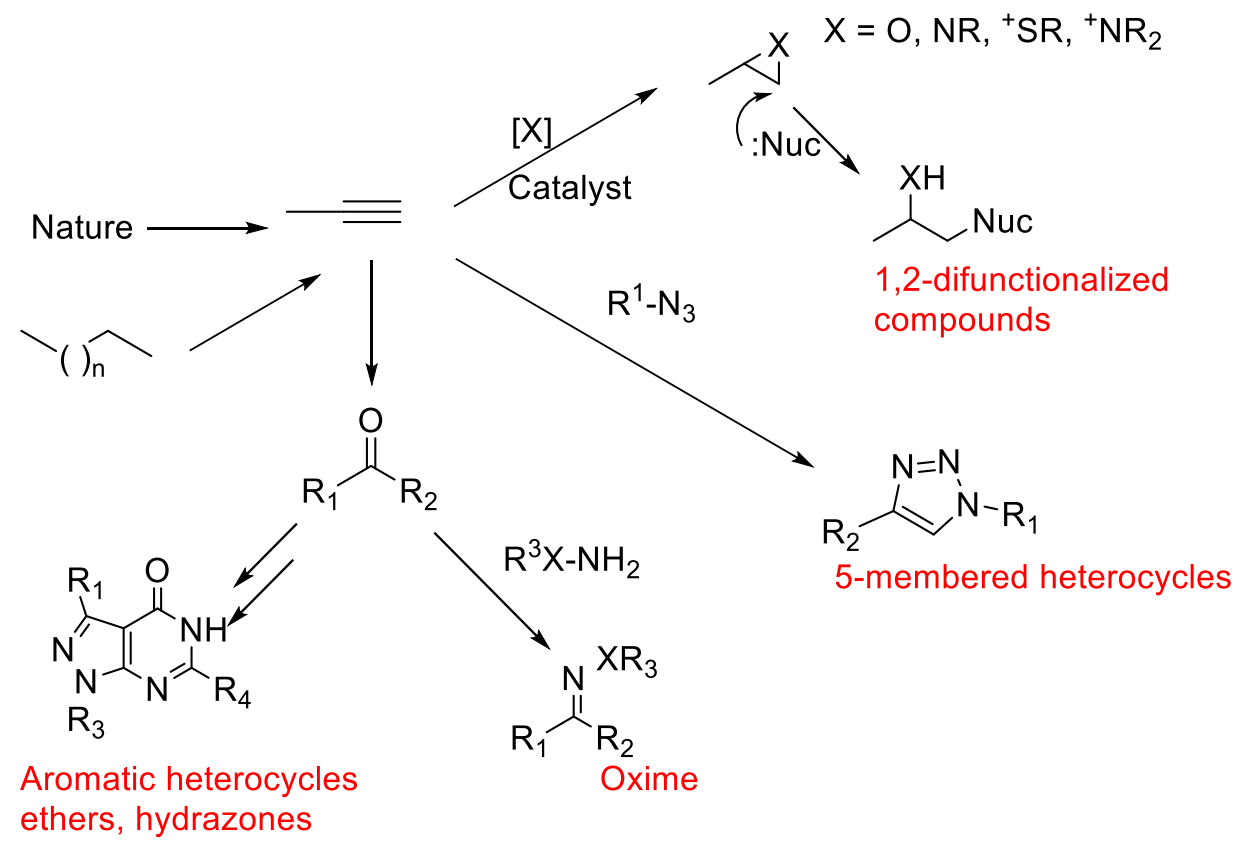

Scheme 2.1. Click Chemistry - energetically highly favorable linking reactions

The potential of this reaction is very high due to the wide range of substituents involving alkynes and azides. Several triazoles have been made by using the Huigsen 1,3cycloaddition reaction before the advent of catalysed reactions. Pearson et al. described the synthesis of monosubstituted dihydropyrrolo-1,2,3-triazole analogue of antitumor dehydropyrrolizidine alkaloid using an intramolecular azide-alkyne cycloaddition, by refluxing the azide in toluene in $55 \%$ yield. $^{73}$

Nevertheless, this reaction has suffered a lack of selectivity for more than 40 years because of the weak directing effect of the substituents yielding a mixture of the 1,4- and the 1,5-regioisomers. Another disadvantage of this reaction is that the formation of products require long heating and the two regioisomers are challenging to separate using classical chromatographic procedures. ${ }^{74}$ 


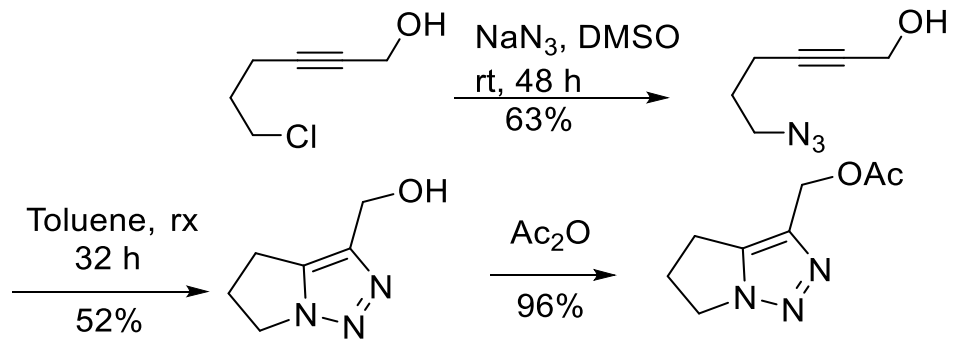

Scheme 2.2. Synthesis of antitumor dehydropyrrolizidine analogue

When the reactants are heated without a catalyst, mixture of 1,4 and 1,5-triazoles are formed. When the reaction is catalysed by ruthenium, only the 1,5-regioisomer is formed. This was shown by Imperio et al. on the synthesis of Steganacin and Podophyllotoxun analogues to replace the lactone ring by 1,5 -disubstituted triazole selectively. ${ }^{75}$ However, the copper catalysed azide-alkyne cycloaddition $(\mathrm{CuAAC})$ reaction produces only the 1,4-regioisomer.

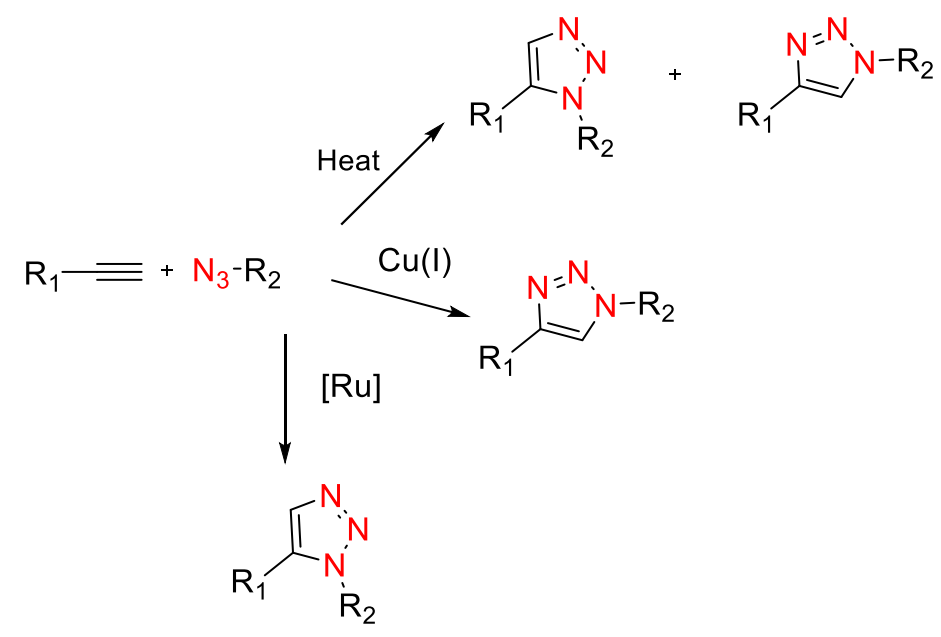

Scheme 2.3. The 1,3-dipolar cycloaddition between azides and alkynes 


\subsection{Copper catalysed Azide-Alkyne cycloaddition}

The copper(I)-catalyzed cycloaddition reaction between azides and terminal alkynes to give 1,4-disubstituted 1,2,3-triazoles has become the benchmark of 'click chemistry'. This reaction is very reliable, selective, biocompatible and exhibits a broad scope. ${ }^{76}$ It was reported that the copper (I) salts were able to accelerate the reaction by up to 10 million times. ${ }^{77,80}$

One of the starting materials, azide, has a unique advantage of stability towards $\mathrm{H}_{2} \mathrm{O}, \mathrm{O}_{2}$ and other organic synthetic conditions. Azide and alkyne functional groups are not reactive to other functionalities because of their high kinetic barrier. ${ }^{81}$ Usually the reaction proceeds to completion in 6-36 hours at ambient temperature (room temperature to $50^{\circ} \mathrm{C}$ ). The catalyst is prepared in situ by reducing $\mathrm{Cu}(\mathrm{II})$ to $\mathrm{Cu}(\mathrm{I})$ salts using sodium ascorbate/ascorbic acid to get a cheaper and purer source. Sodium Ascorbate has proven to be an excellent reducing agent at $0.25-2 \%$ catalyst concentration.

The common solvents used include mixture of tert-butanol/ethanol and water without using any additional organic solvent. However, when reducing agent is not used, copper(I) salts including $\mathrm{CuI}$ and $\mathrm{CuOTf}: \mathrm{C}_{6} \mathrm{H}_{6}$ can be used directly by utilizing one equivalent of nitrogen base (triethyl amine, DIPEA) in a cosolvent (acetonitrile, tetrahydrofuran, dichloromethane and toluene). ${ }^{77}$

The $\mathrm{CuAAC}$ is a very versatile reaction in that it proceeds best in aqueous systems including serum and whole blood, over a broad temperature range $\left(0-160^{\circ} \mathrm{C}\right)$. Its remarkably insensitivity to wide range of $\mathrm{pH}$ (4 to 12) and stable to redox degredation 
made the reaction to succeed beyond limit in the presence of all functional groups tested to date. ${ }^{78}$

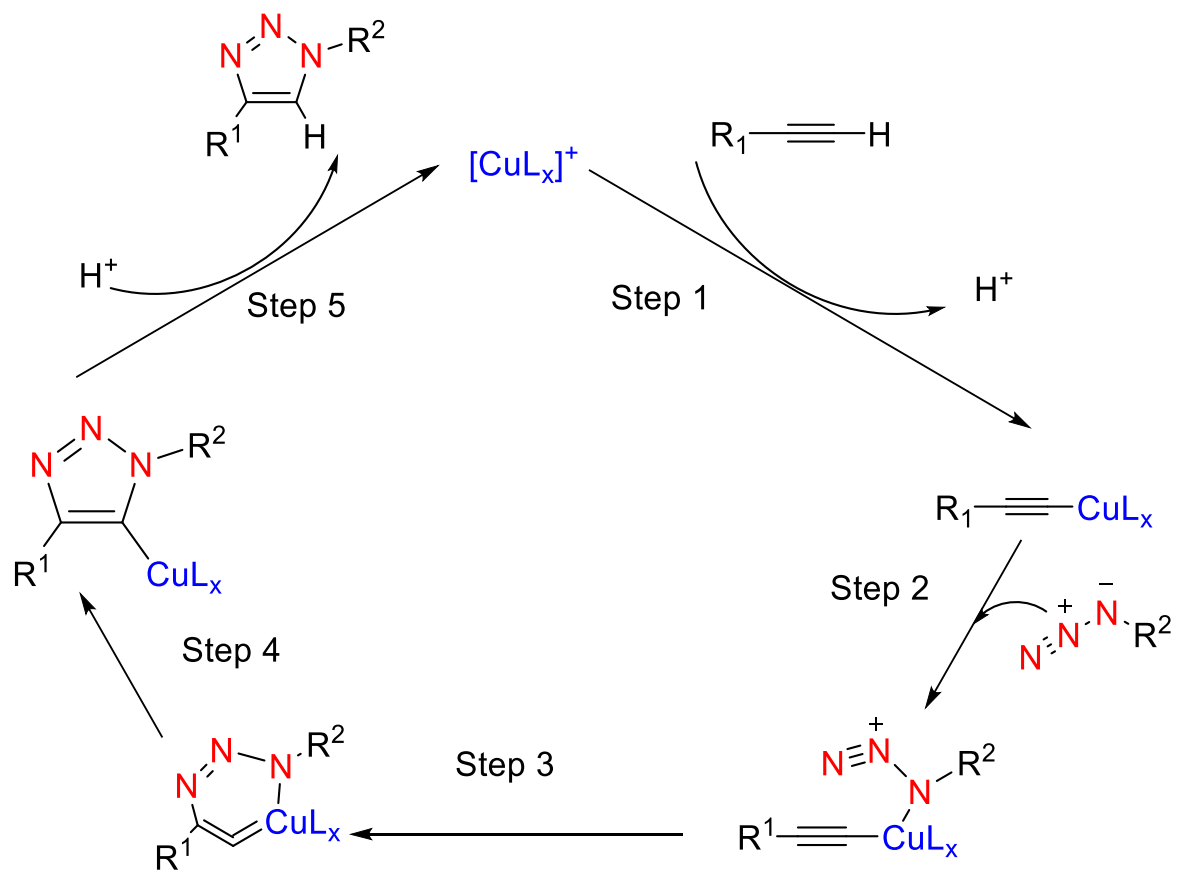

Figure 2.1. Proposed catalytic cycle for the CuAAC reaction

The proposed catalytic mechanism suggests that the 1,3-dipolar cycloaddition of terminal alkynes and azides is catalyzed by copper(I) salts via the formation of copper-acetylide complex, followed by a stepwise or concerted addition to an azide. This mechanism makes the catalysis not to be functional on internal alkynes. ${ }^{80}$

\subsection{Applications of Click Chemistry}

Click chemistry is originally developed for assisting medicinal chemists to have a triumph over combinational chemistry issues. Based on solution-phase library synthesis, Lexicon Pharmaceuticals synthesised 200,000 compounds of acceptable purity on 25-50 
mg scale using click chemistry. The application of click chemistry is wide ranging from drug discovery to material science. ${ }^{81}$

The applicability of click chemistry in bioconjugation involves the attachment of synthetic labels to biomolecular framework covalently. CC enables lengthy bioconjugation processes of 60 steps with more than $99.8 \%$ yield. The bioorthagonal properties and solvent tolerance make azides and alkynes very important groups in bioconjugation. ${ }^{82}$ The first application of $\mathrm{CC}$ in bioconjugation was shown by making 1,4-substituted $[1,2,3]$-triazoles in peptide backbones. ${ }^{80}$ Because the presence of copper in CuAAC may create hinderance to bioorthogonal conjugation in living systems, copperfree click chemistry is applicable using Dibenzcyclooctyl (DBCO) as a source of alkyne.

After introduction of $\mathrm{CC}$, its significance in materials science, specifically in polymer synthesis, was demonstrated by the synthesis of triazole-based dendrimers. The unique properties and application made dendrimers to receive much attention. The main problem in the purification during dendrimer synthesis was solved by the fidelity of CuAAC. ${ }^{83}$ The first triazole-based dendrimer was synthesiszed by sequential click reactions on bisalkynyl scaffold flexible with an azide anion substitution. The ability of polydentate 1,4disubstituted 1,2,3-triazole ligands to stabilize $\mathrm{Cu}(\mathrm{I})$ species under physiologic conditions has proven vital applicaton in biological systems. ${ }^{84}$

Click chemistry has shown to have a cutting-edge application in the demanding world of medicinal chemistry in developing novel approaches to screening compound libraries. One of the main reason which makes $\mathrm{CC}$ reliable in drug discovery is that the compounds 
can be screened directly from the reaction mixture. This was shown in the discovery of Human $\mathrm{r}$-1,3-fucosyltransferase enzyme when the $\mathrm{Cu}(\mathrm{I})$-catalyzed triazole synthesis was utilized to create library of GDP (guanosine diphosphate)-triazole candidates as the crude aqueous reaction were tested directly ${ }^{85}$ The other applications of click chemistry include glycoscience, peptide chemistry, supramolecular chemistry, oligonucleotide synthesis and others. $^{82}$

\subsection{Click chemistry in Drug discovery}

It is a challenging task for medicinal chemists to develop new patentable drugs with strong activity and good ADMET properties in short time. The triazole-forming Click chemistry accelerates drug discovery in hit finding and lead optimization due to its reliance on extremely quick reactions in high yield.

Most of triazole containing drugs available so far are enzyme inhibitors, receptor ligands, peptides, and modified natural products. There are few drugs available on the market or in clinical trials including anticancer carboxyamidotriazole (CAI), the nucleoside derivative non-nucloside reverse transcriptase inhibitor Tertbutyldimethylsilylspiroaminooxathioledioxide (TSAO), $\beta$-lactum antibiotic Tazobactum and the cephalosporine cefatrizine. ${ }^{76}$ 

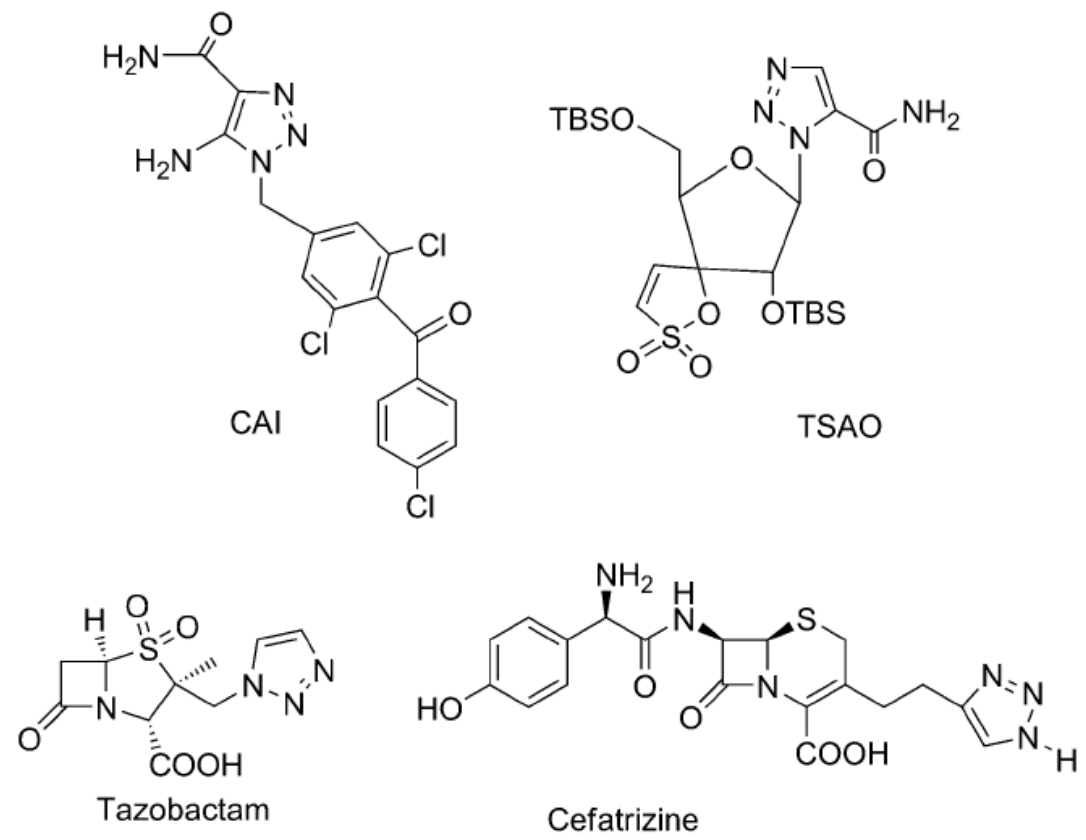

Figure 2.2. Drugs based on 1,2,3-triazoles ${ }^{76}$

Before Click chemistry came into action, several molecules that contain 1,2,3triazole moiety were synthesized using various methods. These include anticancer, antibacterial, antimalarial, antifungal, antitubercular, antiviral, antihypertensive, and hypocholesterolemic agents. ${ }^{76}$

Pisaneschi et al. synthesized 3-cyanoquinoline-based fluorinated compounds that would make a good imaging agent for epidermal growth factor receptor (EGFR) to facilitate the clinical evaluation of tumors. One of the 20-fluoroethyl-1,2,3-triazoles showed to have good cellular potency, low lipophilicity and good metabolic stability in vitro to be a promising radiotracer for imaging of EGFR status. ${ }^{86}$ Another new class C5- curcuminoid4-aminoquinoline molecular hybrids has shown potential anticancer activity when tested on 60 human cancer cell lines at $\mathrm{nM}$ concentration. ${ }^{87}$ 


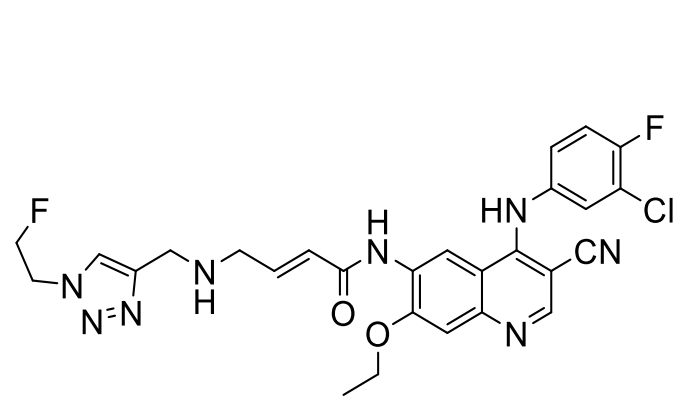

Pisaneschi et al.

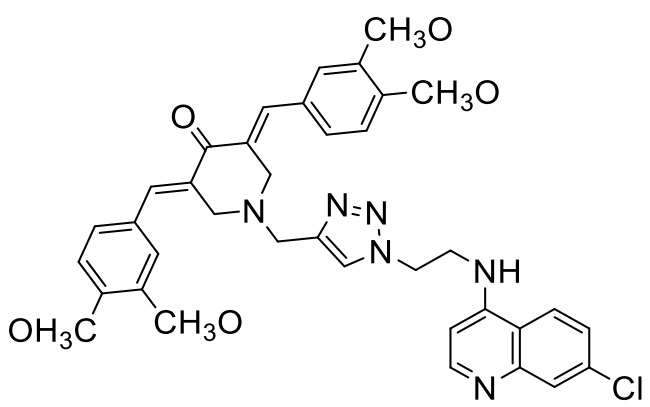

Rawat et al.

Figure 2.3. Triazole based anticancer molecules

The application of Click chemistry of 1,2,3-triazoles in synthesizing new class of antifungal and antimicrobial agents is becoming prevalent. ${ }^{76}$ A series of substituted triazoles were synthesized using 1,2,3-triazole containing quinoline moiety and tested for their antimicrobial and antifungal activity. SAR investigation revealed that the nature of the substituent on the 4-position of the triazole ring influences the antimicrobial activity. When evaluated for in vitro activity and compared with standard antifungal Cyclopiroxolamine, the 3-methylthien-2-yl moiety showed a broad spectrum antimicrobial activity against all tested strains. ${ }^{88}$

Two substituted 1,2,3-triazoles containing quinoline moiety showed good antibacterial and moderate antifungal activity, particularly the compounds with 3-methyl thienyl substituents are found to have increased antimicrobial activity ${ }^{89}$ In other study, Thomas and co-workers reported in vitro activity of similar antibacterials and antifungals. The compounds demonstrated moderate to very good activities, when comparable to 
Ciprofloxacin and Ciclopiroxolamine respectively. The enhanced activity is due to the presence of active piperazine and its derivatives in their structures. ${ }^{90}$

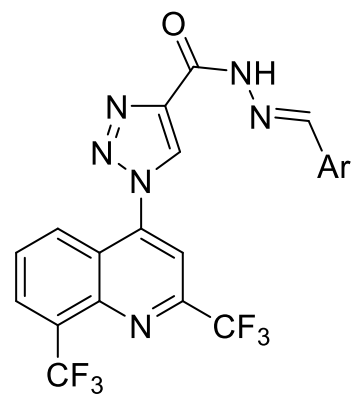

Sumangala et al

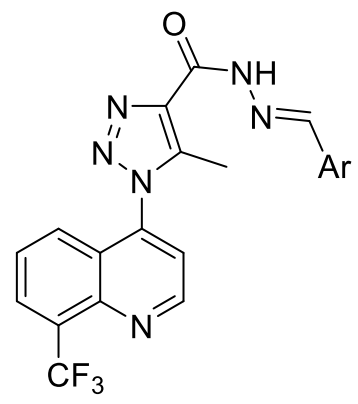

Holla et al<smiles>Cc1cc(-n2cc(CNN3CCNCC3)nn2)c2cc(CO)ccc2n1</smiles>

Thomas et al

Figure 2.4. Triazole based antibacterial and antifungal molecules

Olomola et al synthesized anti-HIV triazole-based hybrids using $\mathrm{Cu}(\mathrm{I})$-catalysed cycloaddition reaction by combining 3-alkynylmethylcoumarins with azidothymidine (AZT). The structurally complex coumarin-AZT conjugates have the potential dualaction as HIV-1 protease and non-nucleoside reverse transcriptase inhibitors. ${ }^{91}$

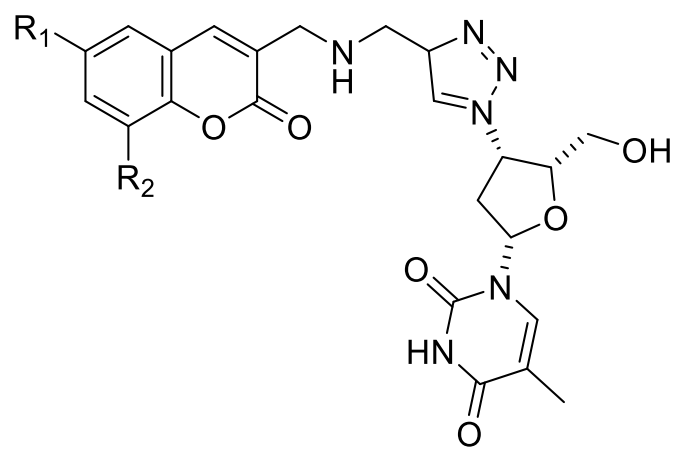

Figure 2.5. Triazole based anti-HIV hybrid molecule 


\subsection{Triazole based Antimalarials}

The modification of well-established antimalarials, particularly chloroquine is very common in making new drugs to counteract drug resistance. Different groups reported the synthesis of 1,2,3-triazole based quinoline moieties using copper(I)-catalysed cycloaddition click chemistry.

A series of 4-aminoquinoline-1,2-3-triazole based hybrids were synthesized and evaluated for their in vitro antimalarial acivity against D6 and W2 strains of $P$. falciparum. Some of the compounds have shown promising antimalarial activity without showing any toxicity against Vero cells. ${ }^{92}$ On the similar studies done by Mamgain et al., the absence of linear alkyl chain linker have shown to diminish the antimalarial activity. ${ }^{93}$

Pereira et al directly clicked 7-chloroquinoline with different substituents in position $\mathrm{C} 4$ of the quinoline at the $\mathrm{N} 1$ of the triazole ring. When evaluated for their in vitro activity against $P$. falciparum (W2), the compounds showed moderate antimalarial activity and low cytotoxicity to Hep G2A16 cells. The decreased activity was explained by the low resonance contribution of the triazole ring to stabilize the acidic form of the quinoline ring that decreases the $\mathrm{pKa}$ of the quinoline nitrogen. ${ }^{94}$

Another set of triazole molecules was made by the Blackie group using the mefloquine pharamacophore by $\mathrm{CuAAC}$ chemistry. The in vitro biological activity of the compounds on NF54 chloroquine-sensitive strain of Plasmodium falciparum was determined to be in the lower $1.0 \mathrm{uM}$ range. The authors concluded that the inclusion of the piperazine does 
not appear to be advantageous in biological activity because the single basic nitrogen in the side chain seemed to provide sufficient basicity to maintain activity. ${ }^{95}$
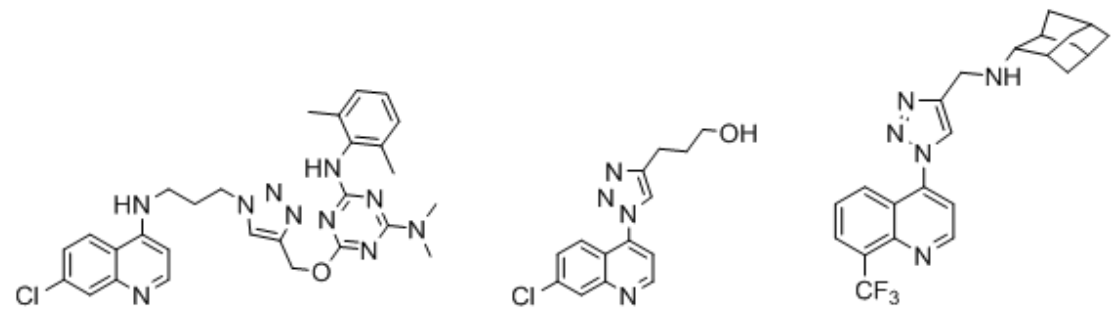

$$
\begin{aligned}
& \text { Manohar et al } \\
& \left(0.58^{\mathrm{D} \mathbf{2}}, 0.73 \mathrm{uM}^{\mathrm{W} \mathbf{2}}\right)
\end{aligned}
$$

$$
\begin{aligned}
& \text { Pereira et al } \\
& \left(9.6 \mathrm{uM}^{\mathrm{W} 2}\right)
\end{aligned}
$$

Hamann et al $\left(1.00 \mathrm{uM}^{\mathrm{NF54}}\right)$

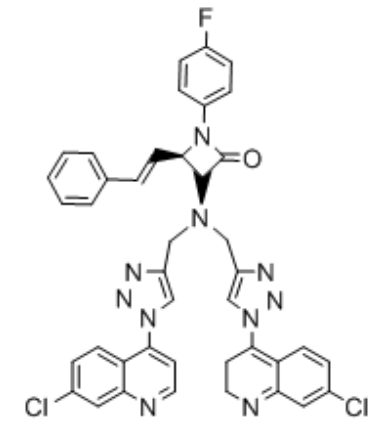

$$
\text { Singh et al }
$$$$
\left(1.1 \mathrm{uM}^{\mathrm{W} 2}\right)
$$

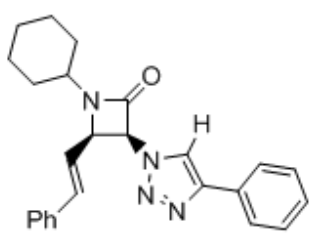

Singh et al $\left(1.13^{3 \mathrm{D} 7}, 1.21^{\mathrm{kl}}, 1.00^{\mathbf{W} \mathbf{2}}\right)$

Figure 2.6. Triazole based antimalarials

Many hybrid drugs were synthesized by combining 7-chloroquinoline moiety with other drugs. The synthesis and antimalarial activities of 1H-1,2,3-triazole tethered 7chloroquinoline-Isatin hybrids was shown by Raj and others. The compound with three carbon alkyl chain and chloro substituent at the $\mathrm{C}-5$ position of the isatin ring displayed the best activity against cultured W2 strain among the test compounds. ${ }^{96}$ 
1,2,3-Triazole tethered $\beta$-lactam and 7-chloroquinoline bifunctional hybrids were synthesized and evaluated against W2 strain of $P$. falciparum for their antimalarial activities. The activity was found to be dependent on the $\mathrm{N}$-substituent of the $\beta$-lactam ring and the bis-triazole at the $\mathrm{C}-3$ position, and the p-fluorophenyl substituted analogue showed maximum activity. Docking studies via inhibiting P. falciparum dihydofolate reductase (PfDHFR) enzyme was made to explain the activity. ${ }^{97}$

Other non-quinoline based antimalarial compounds having 1,2,3-triazole pharamacophore were made using click chemistry. Triazole-based $\beta$-lactams were synthesized and evaluated for their antiplasmodial activity against 3D7, K1, and W2 strains of Plasmodium falciparum, and $\mathrm{KB}$ cells for their cytotoxicity profiles. The compound with an N-cyclohexyl substituent in the $\beta$-lactam ring and a phenyl group on the triazole showed better antiplasmodial activity and cytotoxicity. ${ }^{98}$

\subsection{Triazoles as Pharmacophores, Bioisosters and Linkers}

The importance of triazolic compounds in medicinal chemistry is undeniable. There are three main groups of 1,2,3- triazoles: monocyclic, benzotriazoles and 1,2,3-triazolium salts. Based on the position of the substituent, the monocyclic 1,2,3- triazoles are subdivided into $1 \mathrm{H}-, 2 \mathrm{H}-$ and $4 \mathrm{H}-1,2,3$-triazoles. The $1 \mathrm{H}-$ and $2 \mathrm{H}$ - forms are tautomers in equilibrium both in solution and gas phase. The $1 \mathrm{H}-1,2,3$-triazole acts as both weak base $\left(\mathrm{pK}_{\mathrm{a}}=1.17\right)$ and weak acid $\left(\mathrm{pK}_{\mathrm{a}}=9.4\right)$, and the ring is not protonated at physiological $\mathrm{pH}^{76,99}$ 
The acidity and basicity of nitrogen atoms in 1,2,3-triazoles is explained well by their resemblance of having both pyrrole and pyridine-like electronic properties respectively. The pyridine-type nitrogen is weakly $\sigma$-donating and strongly $\pi$-accepting while the fivemembered pyrrole offers an amine-like nitrogen which makes it $\sigma$-accepting and $\pi$ donating, causing an aromatic system of $\pi$-electron excess. ${ }^{100}$

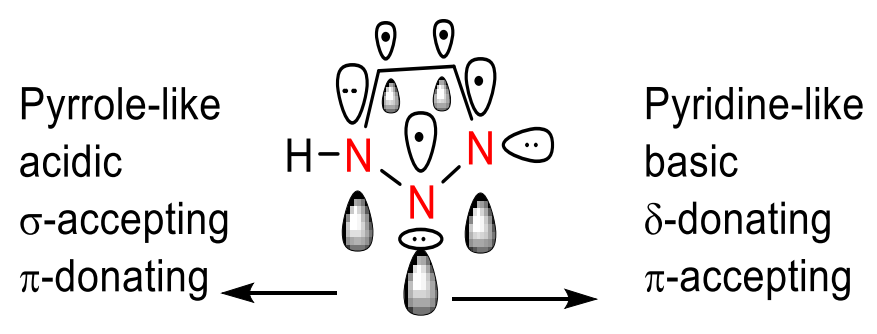

Figure 2.7. Electronic structure of 1H-1,2,3-triazole

The 1,2,3-triazole ring exhibits three resonance forms at which the three $\mathrm{N}$-atoms cause the aromatic $\pi$-system to be very polarized on a $\sigma$-framework. When both resonance and inductive effect are assessed, the two $\mathrm{C}$-atoms and the $\mathrm{N}$-atom in the 1-position showed positive charges, where as the 2- and 3-Nitrogen atoms indicated partial negative charges. The experimental and computational data showed to be consistent indicating a very large dipole moment of 4.38 and $4.55 \mathrm{D}$ respectively. ${ }^{100}$

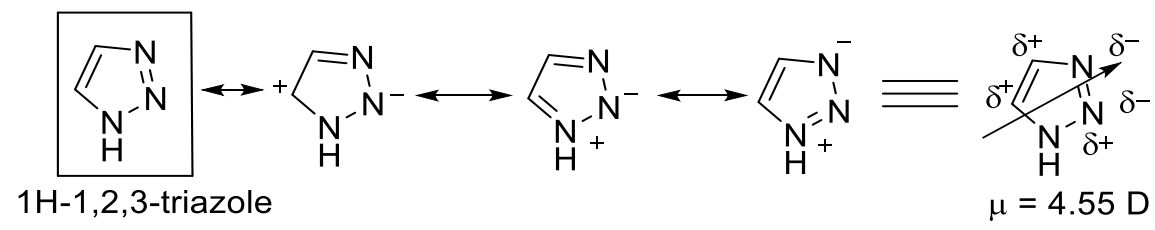

Figure 2.8. Structures, tautomerism, partial charges \& dipole moments of the 1H-1,2,3-triazole 
Although the incorporation of 1,2,3-triazoles into pharmacologically active molecules had been started decades ago, it became more popular after the introduction of coppercatalyzed click chemistry. The triazole group not only functiones as a passive linker but also as a key part of the pharmacophore. The stabilty to acid-base hydrolysis, oxidativereductive conditions and resistance to metabolic degradation make triazoles excellent candidates as pharmacophores. Moreover, these heterocycles readily associate with biological targets via H-bonding and dipole-dipole interactions. ${ }^{74,76,101}$

According to the arenology principles, triazoles have been employed to substitute labile functional groups such as amides and esters to generate functional, nonclassical bioisosteres. ${ }^{102}$ Due to the wide application of peptide chemistry, the bioisosteric replacement of amide bonds with triazole ring is becoming an interest. Depending on the substituent pattern of the triazole, disubstituted 1,2,3-triazoles can replace either trans- or cis-configuration of the amide bond. The presence of both hydrogen bond donor and acceptor at similar positions, and closely related dipole moment make 1,2,3-triazloes ideal bioisosters for amides. ${ }^{103}$

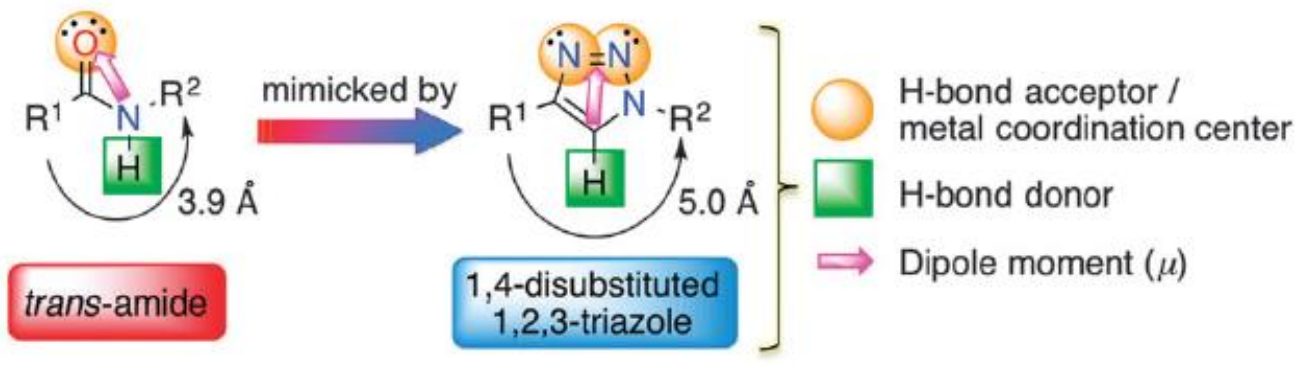

Figure 2.9. Disubstituted trans-amides and 1,2,3-triazoles as bioisosteres ${ }^{102}$ 
The ability to function as rigid linking units makes 1,2,3-triazoles to be extremely stable to hydrolysis and an excellent replacement for amides. Phillips et al. have replaced the amide group of Linezolid, an oxazolidinone antibiotic, with a 1,2,3-triazole ring and showed the retention of antibacterial activity. ${ }^{104}$ In other similar work, 1,2,3-triazolecontaining novobiocin analogs were designed and synthesized by replacing the amide moiety. The analogues exhibited comparable antiproliferative activity when evaluated against two breast cancer cell lines. ${ }^{105}$<smiles>[R2]c1ccc(N2CC(CNC(C)=O)OC2=O)cc1[R]</smiles>

Linezolid analogues<smiles>[R]c1cn(-c2cc3ccc(OC4OC(C)C(C)(C)C(C)C(O)C4O)c(C)c3oc2=O)nn1</smiles>

Figure 2.10. 1,2,3-Triazoles used as bioisosters of trans-amides

The triazole moiety has also been shown to act as a non-classical bioisostere of an ester group in arecoline, a muscarinic agonist, for the treatment of Alzheimer's disease. ${ }^{106}$ Because of the basic aromacity of 1,2,3-triazoles, they are suitable isosters of heteroaromatic rings. In addition, the triazole moiety is also shown to be the isostere of 
double bond. In addition to their pharmacophore role, triazoles have been used as favorable linkers in the synthesis of dimers and bidentate inhibitors. ${ }^{107}$

In order to address the challenges of high costs associated with high-throughput screening and chemical synthesis, Durrant and McCammon developed a novel computer algorithm, called AutoClickChem, capable of performing many click chemistry reactions in silico that may prove useful in rational drug design and optimization. AutoClickChem, which combines virtual screening and click chemistry, is based on the pymolecule toolbox, a framework that facilitates the development of future python-based programs requiring molecular model manipulation. ${ }^{108}$ 


\section{CHAPTER 3: Synthesis of 1,2,3-Triazole-based Antimalarials}

Series of click compounds were synthesized via copper(I)-catalyzed alkyne-azide cycloaddition reaction using sodium ascorbate as a reducing agent. Based on previous work done in Peyton and other labs, three aliphatic linear chains as linker was considered as optimum length both interms of antimalarial activity and hydrophilicity. ${ }^{63}$

\subsection{First-Generation Click Compounds}

The azide analogue was prepared in three steps with very good yields as outlined in Scheme 3.1. First, the amino-alcohol quinoline (PL16) was synthesized by nucleophilic aromatic substitution of commercially available starting material 4,7-dichloroquinoline with excess aliphatic chain aminoalcohol. The hydroxyl group was mesylated by methane-sulfonyl chloride and triethylamine base to give mesylated-quinoline (PL29). ${ }^{62}$ Finally, the azide analogue (PL409) was prepared by nucleophilic acidification using sodium azide in DMF. ${ }^{109}$

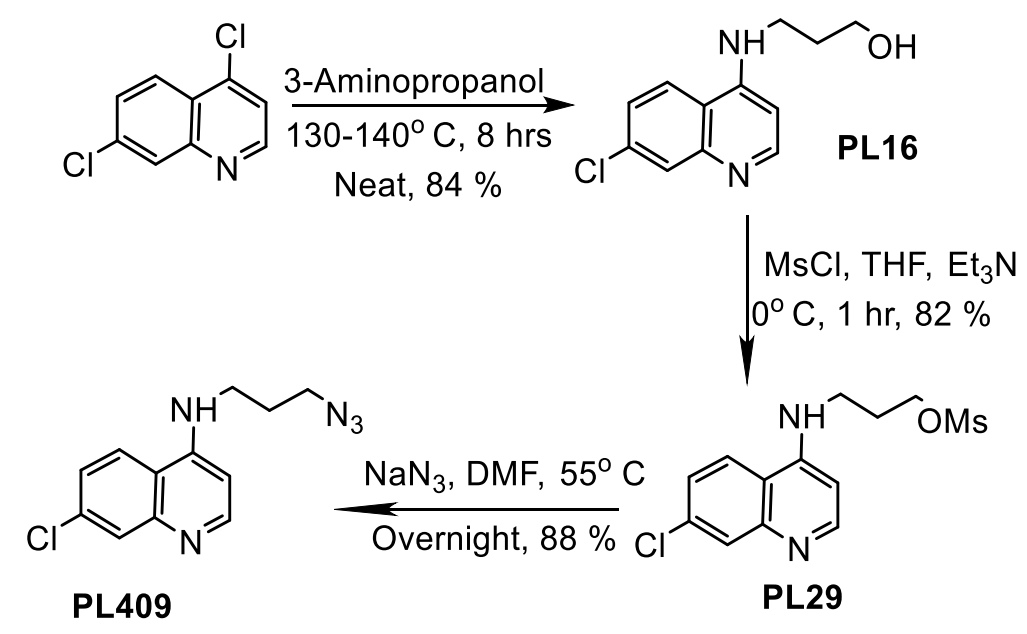

Scheme 3.1. Synthesis of starting material - azide analogue 
The first seven click compounds were synthesized by reacting the azide analogue (PL409), which was prepared in large scale, with commercially available terminal alkynes to give 1,4-disubstituted-1,2,3-triazoles. The method used by Mahohar et al. was adapted by using copper sulfate pentahydrate as catalyst and, two-fold excess of sodium ascorbate to reduce the copper (II) to (I). ${ }^{110}$ An equimolar ratio of tert-butanol and water was used as mixture of solvents. The reactions were run from room temperature with maximum temperature reaching $50^{\circ} \mathrm{C}$ for $3-4$ hours to yield the final target compounds in moderate yield $(26-76 \%)$.

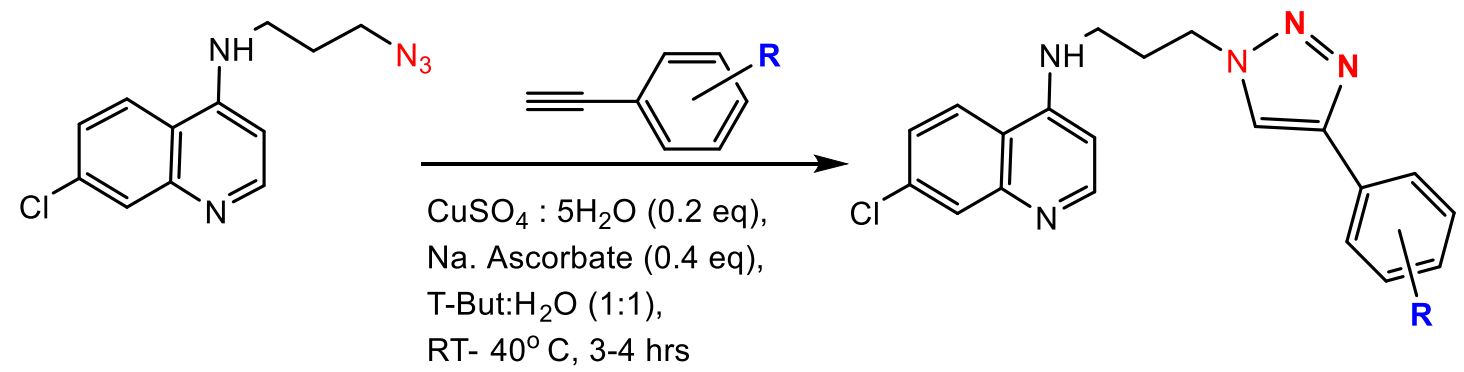

Scheme 3.2. General synthetic pathway of the first generation click compounds

Several substituted terminal alkynes were used as the source of various functional groups. Tri-substituted terminal alkyne with two aromatic groups and a hydroxyl group was of particular interest, due to the similarity with the typical pharmacophore of reversal agents. In addition, both ortho- and meta-methoxy substituted click compounds were synthesized to make a further structure-activity analysis. In order to evaluate the strength of electron-withdrawing groups, monofluoro- and difluoro-substituted click compounds were prepared. Finally, one of the carbons at ortho position of the phenyl group was replaced by nitrogen and the substituted phenyl groups were replaced by a benzyl group. 


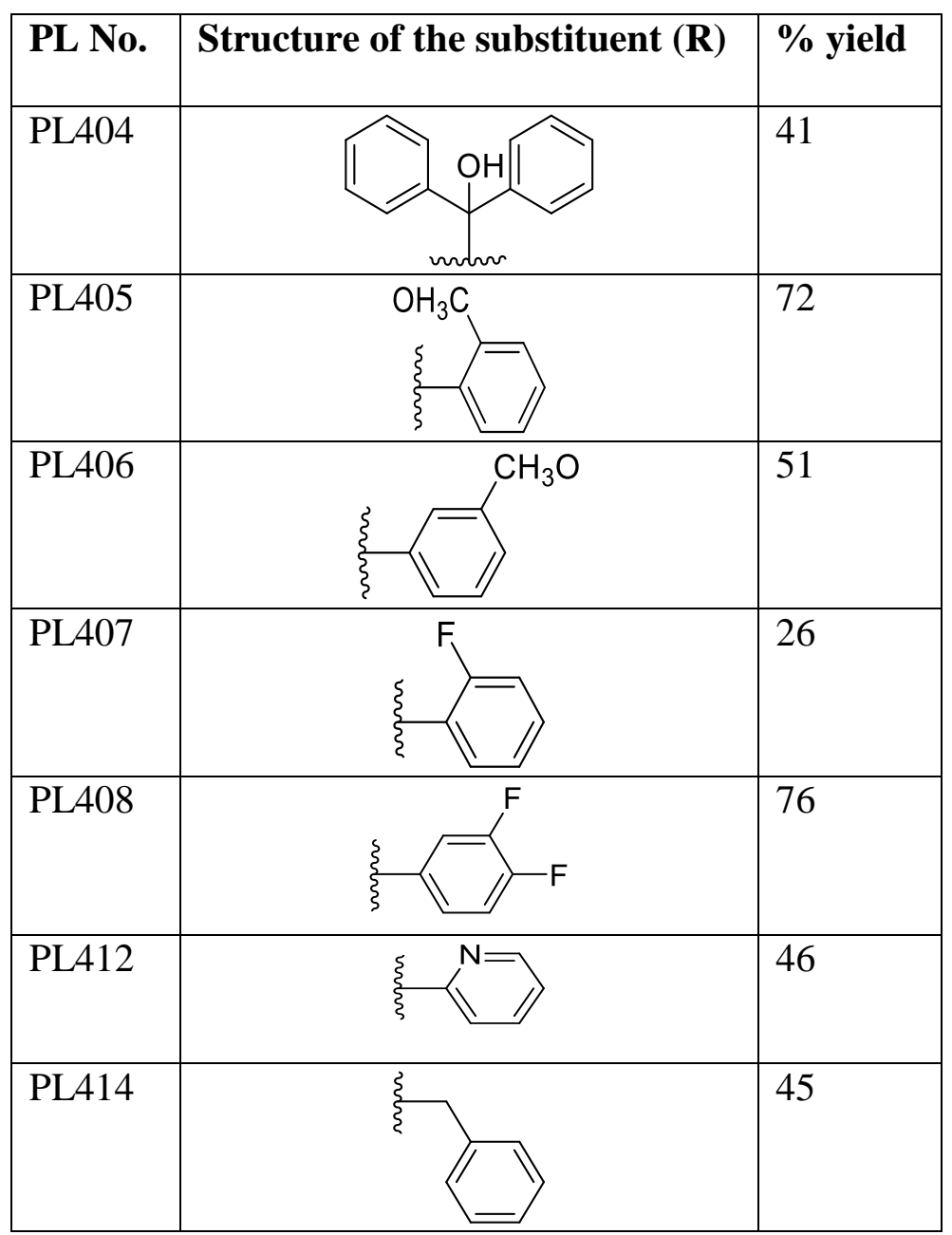

Table 3.1. The first synthesized click compounds

\subsection{Para-Phenyl Substituted Triazoles}

Based on previous compounds synthesized in the Peyton lab by Bornface Gunsaru et al., the para-substituted quinoline analogues showed better activity than their ortho- and meta-substituted counterparts. ${ }^{111}$ Various commercially available p-phenyl substituted terminal alkynes were used to synthesize 10 click compounds using the same synthetic pathway in low to excellent yield $(30-95 \%)$ 


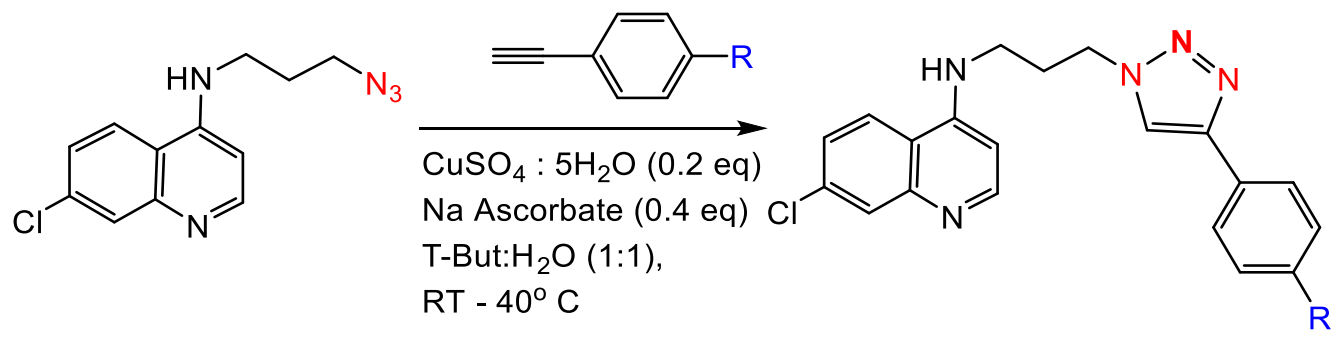

Scheme 3.3. General synthetic pathway of para-substituted click compounds

\begin{tabular}{|l|c|l|}
\hline PL No. & Substituent at para position & \% yield \\
\hline PL403 & $\mathrm{OCF}_{3}$ & 30 \\
\hline PL411 & $\mathrm{H}$ & 50 \\
\hline PL413 & $\mathrm{CH}_{3}$ & 56 \\
\hline PL415 & $\mathrm{NH}_{2}$ & 72 \\
\hline PL416 & $\mathrm{Br}$ & 69 \\
\hline PL417 & $\mathrm{OCH}_{3}$ & 51 \\
\hline PL418 & $\mathrm{Cl}$ & 76 \\
\hline PL419 & $\mathrm{CF}_{3}$ & 68 \\
\hline PL420 & $\mathrm{F}$ & 84 \\
\hline PL421 & $\mathrm{NO}_{2}$ & 95 \\
\hline
\end{tabular}

Table 3.2. Para-substituted click compounds

In order to perform structure-activity relationship studies, several click compounds containing electron-donating and electron-withdrawing groups were synthesized. Unsubstituted (H-substituted) analogue was used as a reference. The p-hydroxy phenyl substitution was not synthesized because the starting material was not readily available. 
Three electron-donating containing analogues, including amino-, methoxy-, and methyl were synthesized. In addition, electron-withdrawing groups such as nitro-, trifluoromethyl-, and the halogens were prepared for comparison. The halogens used was fluorine, chlorine, and bromine (but not iodine). This is because the p-iodo substituted terminal alkyne was not commercially available. Finally, a very interesting long-range electron withdrawing substituent, trifluoromethoxy group, was prepared to compare with the methoxy and trifluoromethyl groups. ${ }^{112}$

\subsection{Triazole with Reversal Agent Pharmacophore}

One additional click compound (PL423) which contains two aromatic rings and nitrogen atom between the triazole and the aromatic rings was made to associate the activity with the reversal agent pharmacophore. First the terminal alkyne (PL422) was synthesized using the Finkelstein reaction by replacing bromine with a better leaving group, iodine. ${ }^{113}$

The benzhydrylamine was treated by propargyl bromide using catalytic amount of sodium iodide in diethyl-ether with minimum heating and fair yield. The synthesized terminal alkyne was reacted with the azide analogue (PL409) under the same condition with the primarily synthesized click compounds to give PL423 in a good yield. 

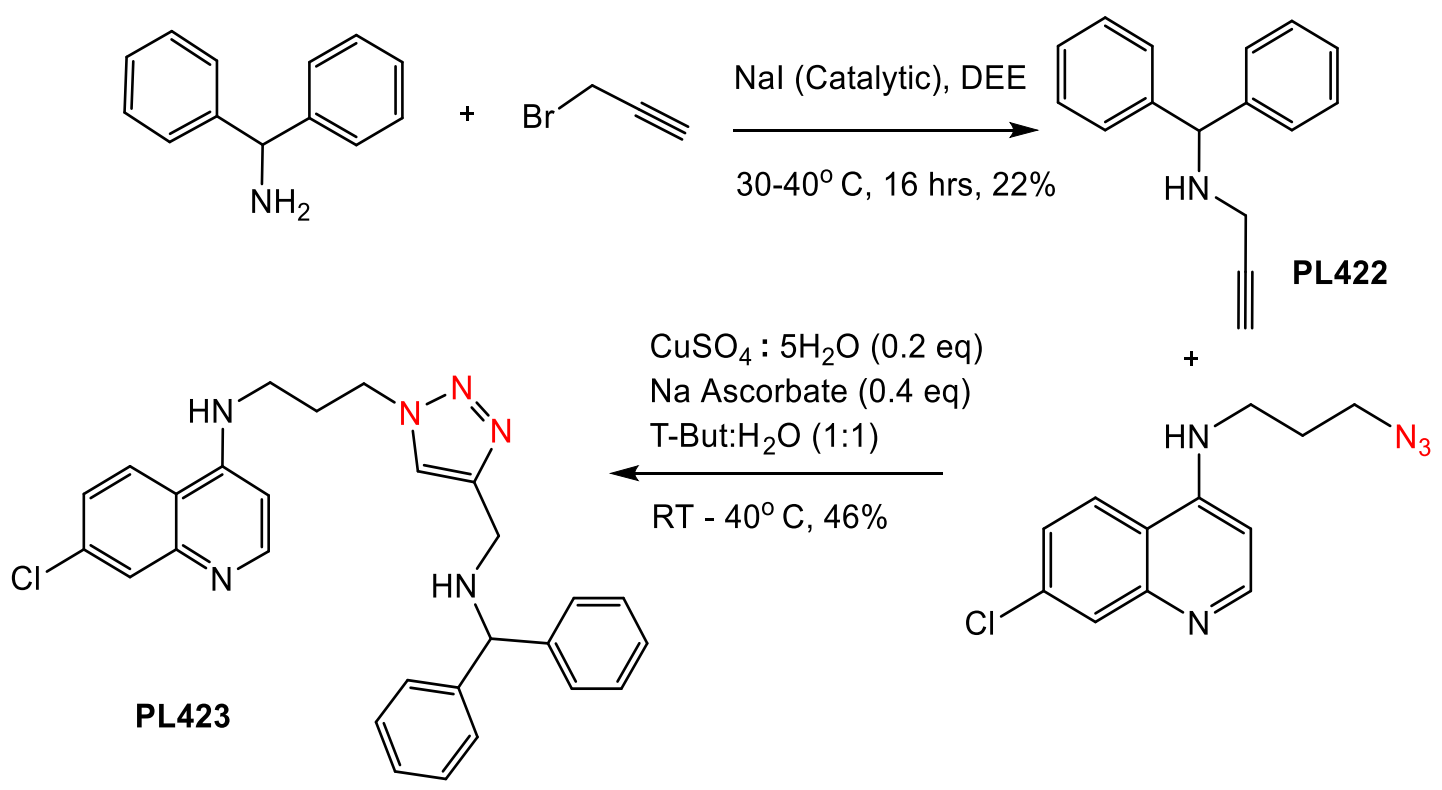

Scheme 3.4. Synthesis of PL423

The first series of 18 click compounds was assessed for their antimalarial activity, and six of them showed better activity than chloroquine against resistant strains of $P$. falciparum (Dd2 and 7G8). Additional compounds containing piperazine ring between the triazole and the aromatic rings were planned to be synthesized in order to incorporate a protonable nitrogen that possesses a weakly basic character.

\subsection{Para-Phenyl Substituted Terminal Alkynes}

With the intention of making piperazine containing triazoles, 10 para-substituted piperazinyl terminal alkynes were prepared. These intermediate molecules were made by reacting equimolar ratio of readily available p-substituted piperazines with propargyl bromide. ${ }^{114}$ The reaction mixture was refluxed overnight using potassium carbonate as a base and acetonitrile as a solvent with moderate to excellent yields. 

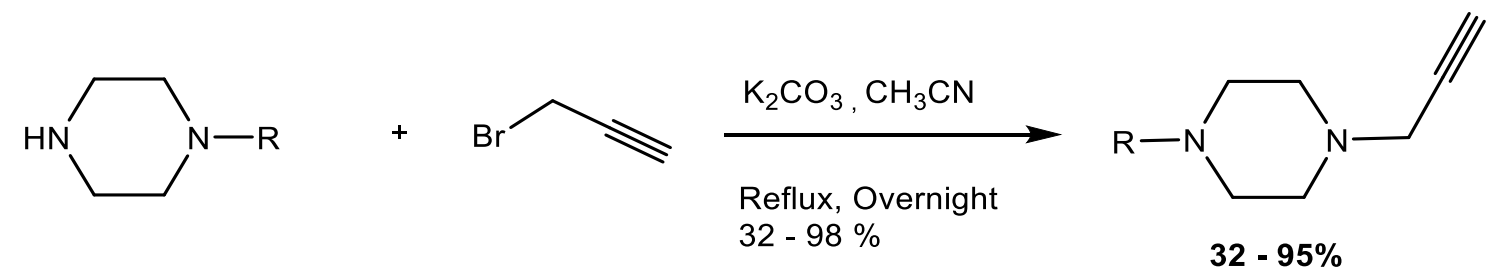

Scheme 3.5. Synthesis of p-phenyl piperazinyl substituted terminal alkynes

\begin{tabular}{|l|l|l|}
\hline PL No. & Structures (R) & \% Yield \\
\hline PL428 & 32 \\
\hline PL429 & \\
\hline PL430 & \\
\hline PL431 & \\
\hline PL433 & \\
\hline PL434 & \\
\hline PL436 & \\
\hline
\end{tabular}

Table 3.3. Structures of 10 piperazine-containing terminal alkynes 


\subsection{Piperazinyl-linked Triazoles}

The p-substituted piperazines were selected based on different functional groups, heteroatomic replacement, linker length between the piperazine and the aromatic ring, and multiple substitution. The cyclohexyl piperazine was selected for comparison of the aliphatic cyclic compound with the phenyl-substituted piperazine. Consequently, nine very interesting piperazinyl containing triazoles were synthesized using CuAAC.

The concentrations of the copper sulphate catalyst and reducing agent sodium ascorbate were reduced by half from the previous method. This was because of the difficulty in solubility encountered during the work-up (liquid-liquid extraction) and purification (recrystallization) processes of the first series of synthesized molecules. ${ }^{96,}{ }^{114}$ The increased reaction time was the cost of reducing the catalyst and reducing agent concentrations which increased from 3-4 hours to 1-2 days. The amount of tert-butanol solvent used was also increased to threefold of the water co-solvent with moderately heating the reaction to $50^{\circ} \mathrm{C}$.

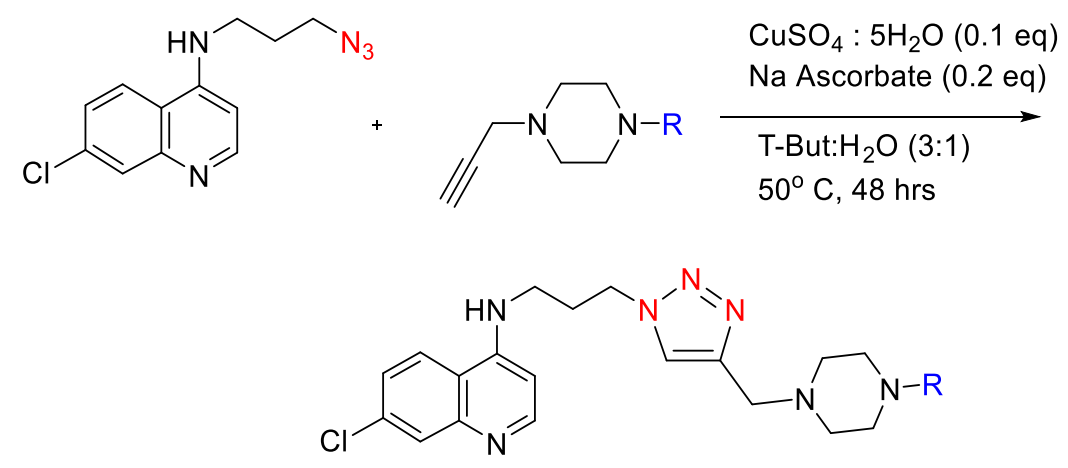

Scheme 3.6. Synthesis of piperazine containing triazoles 
The triazole-based synthesized compounds contain both electron-donating (methyl, methoxy, and hydroxyl) and electron-withdrawing (trifluoromethyl, chloro, and dichloro). The carbon atom at the ortho position of the phenyl group was mono- and disubstituted by nitrogen to give 2-pyridyl and 2,6-pyrimidyl substituted triazoles.

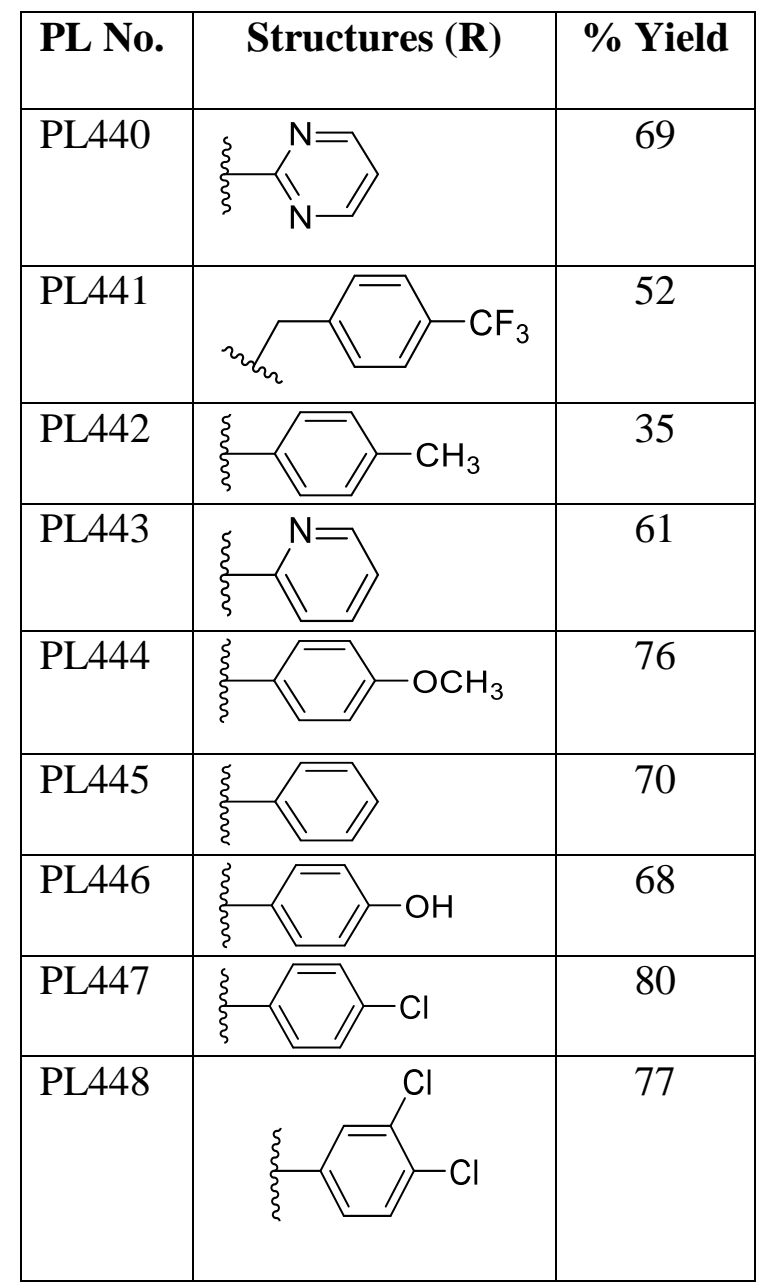

Table 3.4. Structures of piperazinyl-triazoles

The p-trifluoromethyl substituent was made with one aliphatic linker between the piperazine and the aromatic ring. The unsubstituted (H-substituted) phenyl analogue was considered as an optimum reference between electron-donating and withdrawing groups. The di-chloro substituted triazole was also synthesized to notice the change it brings in 
the strengh of the electron-withdrawing capacity of the ring. The click compound containing cyclohexyl substituent was not successful in synthesizing.

\subsection{Triazole-based Bisquinoline Antimalarial}

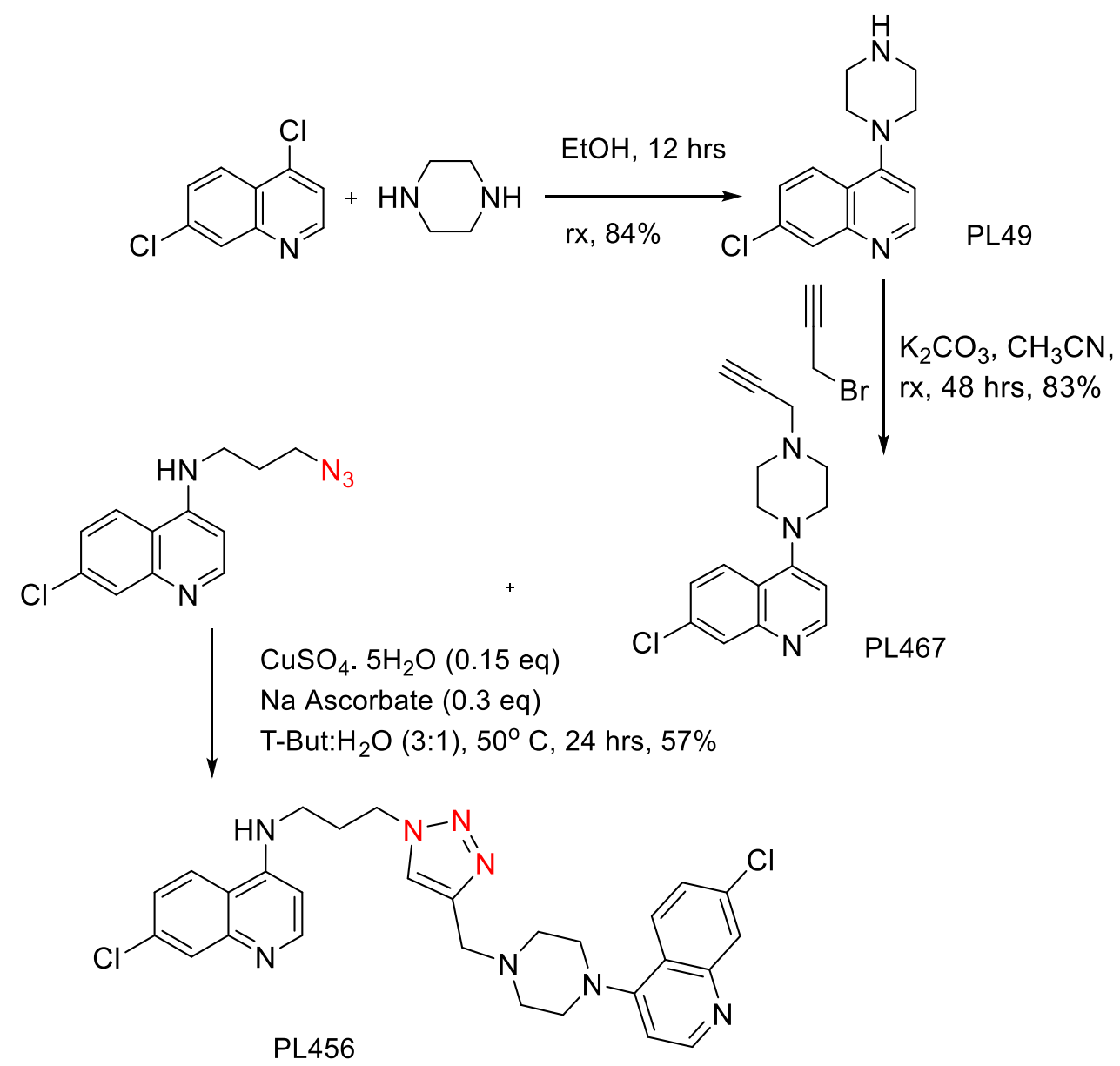

Scheme 3.7. Synthesis of bisquinoline containing triazole

As the potent antimalarial activity of bisquinolines was observed in the previously synthesized compounds in Peyton lab, bisquinoline containing 1,2,3-triazole ring was synthesized by copper catalyzed click chemistry (Scheme 3.7). 
The target bisquinoline was synthesized in three steps with moderate to very good yields. 4-piperazinyl-quinoline (PL49) was first synthesized by refluxing commercially available starting material 4,7-dichloroquinoline with anhydrous piperazine in ethanol. ${ }^{115}$ The terminal alkyne analogue (PL467) was then prepared by reacting PL49 with propargyl bromide using potassium carbonate as a base and acetonitrile as solvent. ${ }^{114}$ Finally, the target bisquinoline triazole (PL456) was made by copper catalysed click reaction in optimum catalytic concentration and reaction time than previous click reactions. 


\section{CHAPTER 4: Structure-Activity Relationship of Triazoles-Based Antimalarials}

The efficiency of synthesizing several triazole-based antimalarials have proven click chemistry to be a fast and efficient route. Antimalarial click compounds were synthesized using copper(I)-catalyzed azide-alkyne cycloaddition reactions and tested for their in vitro activity against D6, Dd2, and 7G8 strains of Plasmodium falciparum. Several of them have shown better activity against chloroquine-resistant strains (Dd2 and 7G8) than chloroquine.

\subsection{The first generation click compounds}

The first generation click compounds synthesized in Peyton lab contain the triazole ring connected directly to one or two aromatic rings with different substitutions. Six of the triazole-based click compunds showed better activity against chloroquine resistant, Dd2 and 7G8, strains of P. falciparum.

Structure-activity relationship studies were made on the synthesized compounds. The phenyl-substituted triazole (PL411) showed an enhanced activity when compared to the 2-pyridyl substituted triazole (PL412) against all the three strains. PL411 gave a better $\mathrm{IC}_{50}$ values of $76.8,87.5$ and $151 \mathrm{nM}$ when compared to 420,960 , and $590 \mathrm{nM}$ (d6, Dd2, and 7G8 strains respectively) of PL412.

In another comparison, PL411 showed decreased activity which compared to PL414 which has an additional methyl linker between the phenyl and the triazole rings. Thus addition of a methyl linker was found to be an advantage over direct connection in this case. 


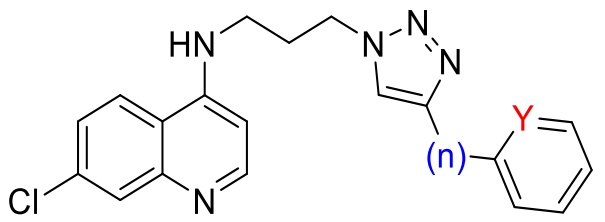

Figure 4.1. The effect of hetroatomic replacement and linker addition

\begin{tabular}{|c|c|c|c|c|c|}
\hline \multirow[t]{2}{*}{ PL No. } & \multirow{2}{*}{$\begin{array}{l}\text { Number of } \\
\text { linker (n) }\end{array}$} & \multirow{2}{*}{$\begin{array}{l}\text { Type of } \\
\text { atom (Y) }\end{array}$} & \multicolumn{3}{|c|}{$\mathrm{IC}_{50}(\mathrm{nM})$} \\
\hline & & & D6 & Dd2 & $7 \mathrm{G8}$ \\
\hline PL411 & 0 & $\mathrm{C}$ & 76.8 & 87.5 & 151 \\
\hline PL412 & 0 & $\mathrm{~N}$ & 423 & 696 & 592 \\
\hline PL414 & 1 & $\mathrm{C}$ & 9.6 & 77.7 & 85.8 \\
\hline
\end{tabular}

Table 4.1. The $\mathrm{IC}_{50}$ comparison of phenyl, 2-pyridyl, and benzyl triazoles

The effect of ortho-, meta-, and para-substitutions were also investigated by comparing the electron-donating methoxy group on the phenyl directly connected to the triazole ring. The para-methoxy substituted triazole (PL417) showed an enhanced activity when compared to the meta-substituted (PL406), which inturn also showed a better activity than the ortho-substituted triazole (PL405) against all the three strains.<smiles>Cc1ccc(-c2cn(CCCNc3ccnc4cc(Cl)ccc34)nn2)cc1</smiles>

Figure 4.2. The effect of methoxy group substitution 


\begin{tabular}{|l|l|l|l|l|}
\hline PL No. & Position of methoxy & \multicolumn{3}{|c|}{ IC 50 (nM) } \\
\cline { 3 - 5 } & substituent & D6 & Dd2 & 7G8 \\
\hline PL405 & ortho- & 98.6 & 209.8 & 192.4 \\
& & & & \\
\hline PL406 & meta- & 52.4 & 120 & 122.3 \\
& & & & \\
\hline PL417 & para- & 40.5 & 108.8 & 140.1 \\
& & & & \\
\hline
\end{tabular}

Table 4.2. The $\mathrm{IC}_{50}$ comparison of ortho-, meta-, and para-methoxy substitutions

The electron-withdrawing strength effect of halogens were compared by mono- and difluorinated substitutions on the phenyl ring directly attached to the triazole. It was found that double halogen (fluorine) substitution (PL408) had improved activity by, almost 2.5 times, for both D6 and Dd2 strains, when compared to mono-fluoro substitution (PL407).<smiles>Fc1ccccc1-c1cn(CCCNc2ccnc3cc(Cl)ccc23)nn1</smiles><smiles>Fc1ccc(-c2cn(CCCNc3ccnc4cc(Cl)ccc34)nn2)cc1F</smiles>

$$
\operatorname{PL} 407\left(81^{\mathrm{D} 6}, 109^{\mathrm{Dd} 2}, 129^{7 \mathrm{G} 8}\right) \quad \quad \text { PL408 }\left(23^{\mathrm{D} 6}, 39^{\mathrm{Dd} 2}, 96^{7 \mathrm{G} 8}\right)
$$

Figure 4.3. The effect of mono- and di-fluoro substitution

The long-range electro-withdrawing group, the trifluoromethoxy-substituted triazole (PL403) showed the highest activity among all the 18 synthesized first generation triazoles. It showed about 4 times better activity than chloroquine against both CQ- 
resistant strains. The $\mathrm{IC}_{50}$ values of PL403 are 12.8 and $14.5 \mathrm{nM}$, while CQ has 54 and 63 for Dd2 and 7G8 strains of $P$. falciparum respectively.

When the para-methoxy substituted triazole (PL417) was compared with PL403, the latter showed a superior activity. The replacement of hydrogen atoms by the most electronegative element fluorine presented an 8 times increase in activity. Moreover, PL403 indicated about 2.5 times increase in activity for Dd2 strain, when compared with a similar electron-withdrawing substituent, trifluoromethyl-substituted triazole (PL419).

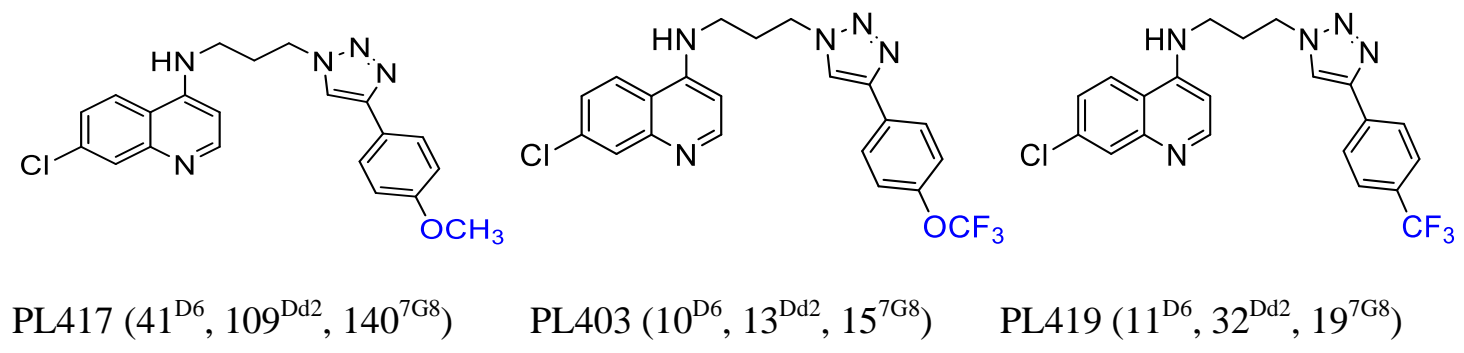

Figure 4.4. Comparison of the $\mathrm{IC}_{50}$ values of para-methoxy, trifluoromethoxy and Trifluoromethyl-phenyl substituted click compounds

The electron-donating substituents showed inferior activities than chloroquine. These include the para-phenyl substitutions of methyl (PL413), amino (PL415), and methoxy (PL417) functional groups. While the para-methyl substituted triazole presented the best activity from the three electron donating groups, the para-amino showed the least activity against all CQ-sensitive and CQ-resistant strains of $P$. falciparum.

However, the electron-withdrawing groups such as the trifluoromethyl, nitro and the halogens presented better or comparable activity than chloroquine. Most of them 
exhibited an improved $\mathrm{IC}_{50}$ values than $\mathrm{CQ}$ against both resistant strains except the parafluoro substituted triazole (PL420).<smiles>FC(F)(F)c1ccc(-c2cn(CCCNc3ccnc4cc(Cl)ccc34)nn2)cc1</smiles>

PL419 $\left(11^{\mathrm{D} 6}, 32^{\mathrm{Dd} 2}, 19^{7 \mathrm{G} 8}\right)$

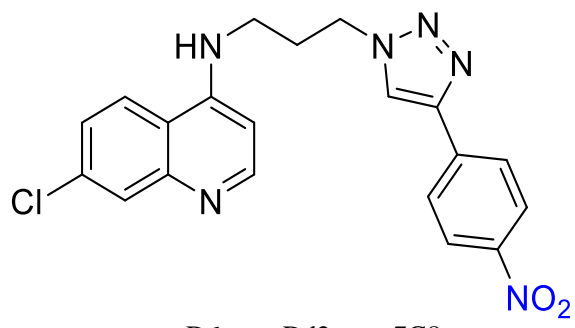

$\operatorname{PL} 421\left(19^{\mathrm{D} 6}, 51^{\mathrm{Dd} 2}, 45^{7 \mathrm{G} 8}\right)$

Figure 4.5. The $\mathrm{IC}_{50}$ values of para-phenyl substituted electron-withdrawing groups

When the halogens are compared, the para-bromophenyl substituted triazole (PL416) showed the best activity against $\mathrm{Dd} 2$ strain of $P$. falciparum $\left(\mathrm{IC}_{50}\right.$ of $\left.30.7 \mathrm{nM}\right)$. The chloro-substituted (PL418) exhibited enhanced activity against both D6 and 7G8 strains ( $\mathrm{IC}_{50}$ of 18.8 and $36.6 \mathrm{nM}$ respectively) than PL416 and the fluoro-substituted triazole (PL420). The general trend for the halogens indicated that the antimalarial activity increases when electronegativity of the substituent atom decreases.

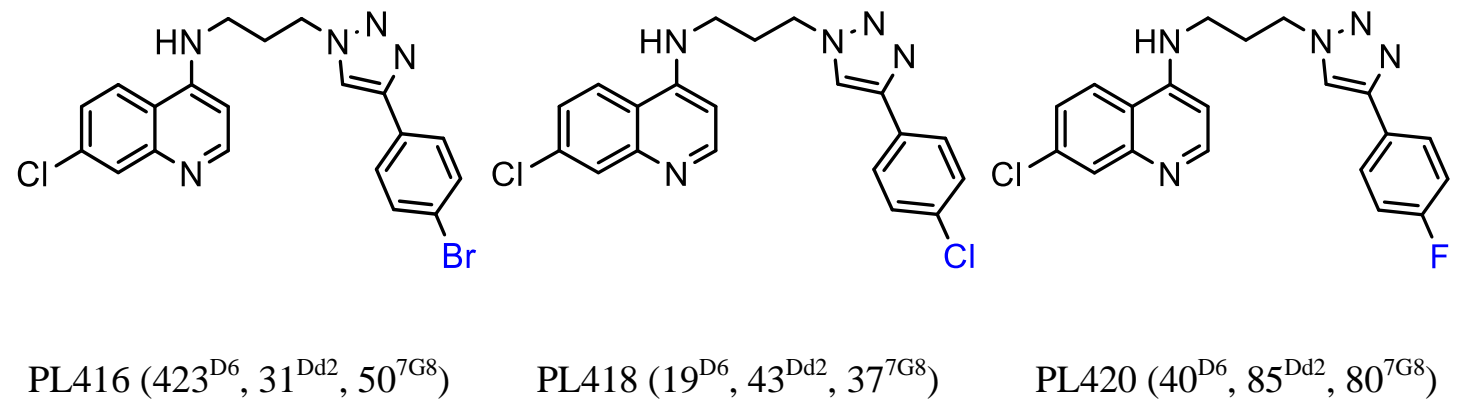

Figure 4.6. The $\mathrm{IC}_{50}$ values comparison of para-halogen substituted triazoles

When all the para-phenyl substituted electron-withdrawing groups are compared, the trifluoromethyl and the chloro substitutions showed potent activities, with trifluoromethyl 
group possessing the highest. The bromo and nitro groups at para position of the phenyl ring indicated moderate activities, with the bromo group retaining the maximum activity of all against Dd2 strain of P. falciparum. The least leaving group, fluorine-substitution, showed the minimum activity of all electron-withdrawing groups.

\begin{tabular}{|l|l|}
\hline Strains of Plasmodium falciparum & Electron-withdrawing group \\
\hline $\mathrm{D} 6$ & $\mathrm{Br}<\mathrm{F}<\mathrm{NO}_{2}=\mathrm{Cl}<\mathrm{CF}_{3}$ \\
\hline $\mathrm{Dd} 2$ & $\mathrm{~F}<\mathrm{NO}_{2}<\mathrm{Cl}<\mathrm{CF}_{3}<\mathrm{Br}$ \\
\hline $7 \mathrm{G} 8$ & $\mathrm{~F}<\mathrm{Br}<\mathrm{NO}_{2}<\mathrm{Cl}<\mathrm{CF}_{3}$ \\
\hline
\end{tabular}

Table 4.3. Comparison of various electron-withdrawing groups

Surprisingly, the two click compounds that contain two aromatic groups resembling the RA pharmacophore showed poor antimalarial activity. The first compound (PL404) which has a tetra-substituted carbon connecting the triazole ring with two aromatic rings and hydroxyl group, showed better activity only against 7G8 strain of P. falciparum. The second click compound (PL423) containing a secondary amine between the triazole and two aromatic rings showed poor antimalarial activity against all the strains.

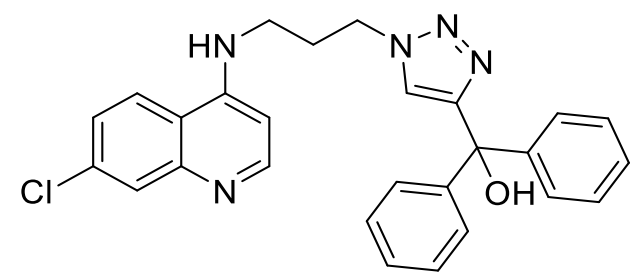

PL404 $\left(25^{\mathrm{D} 6}, 82^{\mathrm{Dd} 2}, 48^{7 \mathrm{G} 8}\right)$

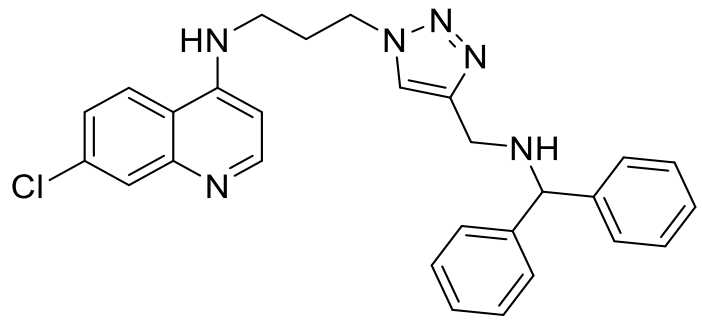

PL423 $\left(80^{\mathrm{D} 6}, 160^{\mathrm{Dd} 2}, 189^{7 \mathrm{G} 8}\right)$

Figure 4.7. Click compounds containing pharmacophore similar to the reversal agent 
Out of the 18 synthesized first generation click compounds, six were found to be more active than chloroquine against CQ-resistant strains of $P$. falciparum. Although none showed better activity against the CQ-sensitive (D6) strain, the trifluoromethoxy (PL403) and trifluoromethyl (PL419) substituted triazoles showed comparable activity with chloroquine ( $\mathrm{IC}_{50}$ values of 10.4 and $11 \mathrm{nM}$ respectively).

All six selected compounds have exhibited better activity against Dd2 strain of $P$. falciparum than chloroquine. For the 7G8 strain, five showed an enhanced activity than CQ except the difluoro-phenyl substituted triazole (PL408), which has an $\mathrm{IC}_{50}$ value of 95.7 nM when compared to $57 \mathrm{nM}$ of CQ (Refer to Table 4.4).

In conclusion, electron-withdrawing (PL416, PL418, PL419, and PL421) and long-range electron-withdrawing (PL403) substitutions at para positions, and double electron withdrawing (PL408) substitutions were found to be an advantage to have a better antimalarial activity for these group of click compounds.

\subsection{Piperazinyl-linked click compounds}

"Second generation" of triazole antimalarials were synthesized by incorporating piperazine ring between the triazole and the para-substituted phenyl ring, to yield a protonable nitrogen in the linker which increases the basicity of the molecule. When compared to the first synthesized click compounds, these 9 compounds generally showed enhanced antimalarial activity against all the strains of $P$. falciparum. 


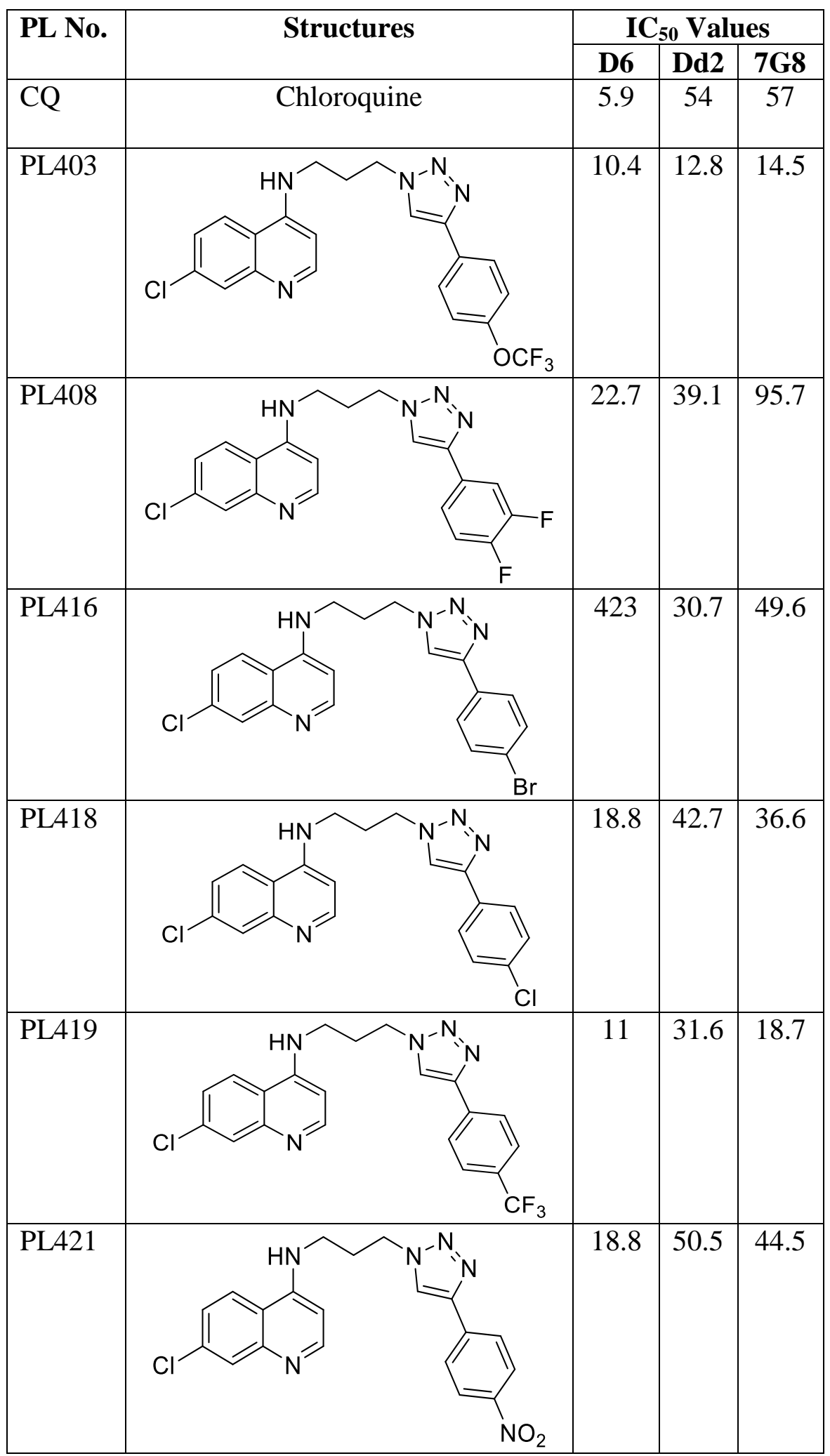

Table 4.4. Selected first generation click compounds with better activity than CQ 
The para-substituted electro-donating groups generally demonstrated better activities than CQ and the first generation triazoles with similar substituents. The para-methyl (PL442) and para-methoxy (PL444) substituted triazoles exhibited an improved activity against Dd2 and 7G8 strains of P. falciparum than did CQ. However, the para-hydroxy substituted triazole (PL446) showed poor activity against all the 3 strains of $P$. falciparum.
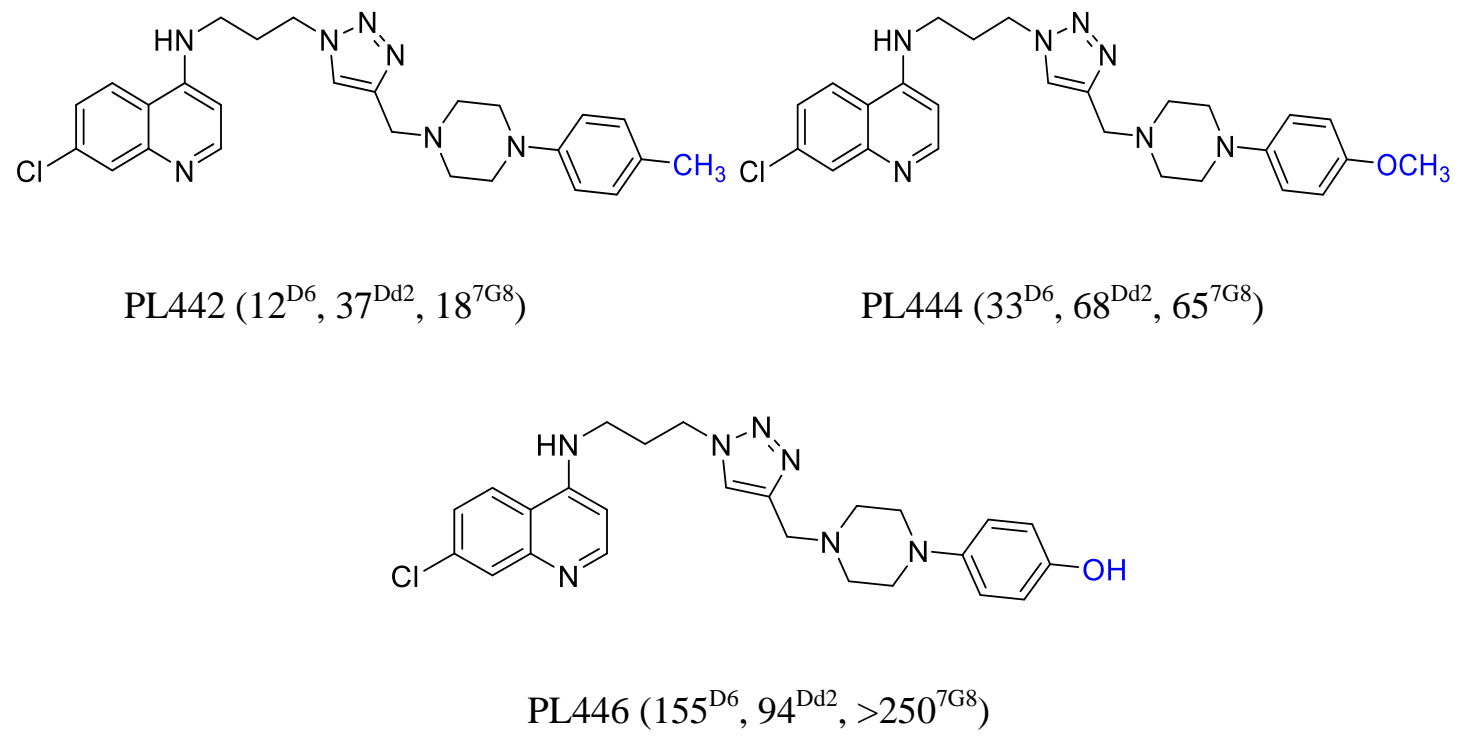

Figure 4.8. The activity of electron-donating groups substituted at the para position

The 2-pyridyl (PL443) and 2,6-pyrimidyl (PL440) Piperizenyl-substituted triazoles gave poor activity against all the three strains of $P$. falciparum when compared to CQ, with PL440 presenting the lowest activity of all the synthesized triazoles.

As the effect of double substitution of electron-withdrawing groups was shown to improve the antimalarial activity in the first series of compounds using fluorine; the same result was obtained with the piperazinyl-linked triazoles. When the dichloro-substituted 
(PL448) was compared with monochloro-substituted (PL447) phenyl-piperazinyl triazole, the former showing about 1.6 times increased activity against all the three stains.

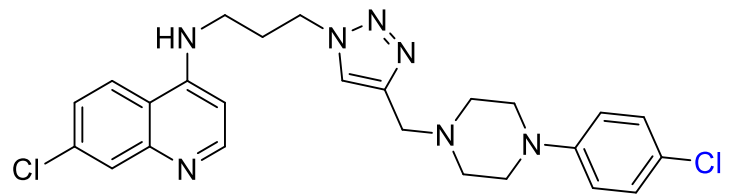

$\operatorname{PL} 447\left(8.8^{\mathrm{D} 6}, 26.5^{\mathrm{Dd} 2}, 19^{7 \mathrm{G} 8}\right)$

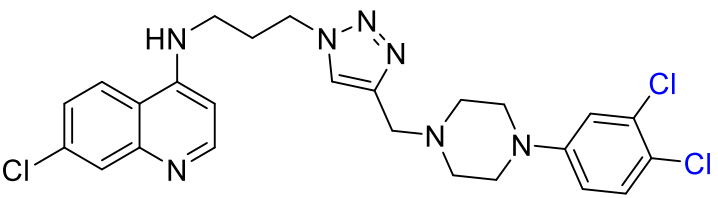

$\operatorname{PL} 448\left(6.8^{\mathrm{D} 6}, 15.2^{\mathrm{Dd} 2}, 11^{7 \mathrm{G} 8}\right)$

Figure 4.9. The comparison of $\mathrm{IC}_{50}$ values of mono and dichloro-substituted triazoles

The addition of a single methyl linker between the piperazine and the phenyl ring have shown to retain the antimalarial activity against all the three strains of $P$. falciparum when the phenyl ring was para-substituted by a trifluoromethyl group.

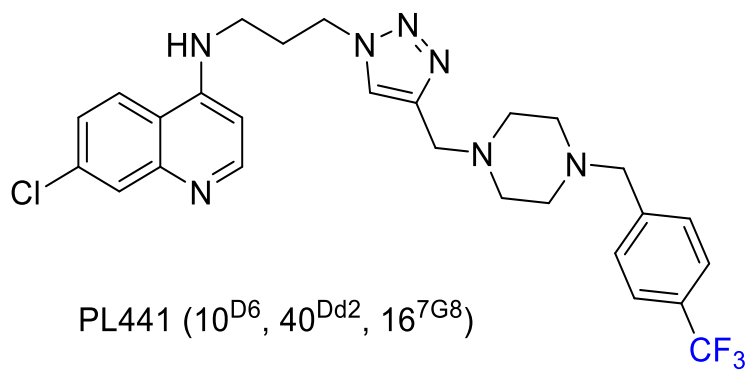

Figure 4.10. Triazole having methyl linker between piperazine and phenyl rings

Improved antimalarial activity was observed when the first series of triazoles were compared with piperazine linked for the same substituents. This increase in activity is attributed to the integration of the piperazine linker, which provides additional proton for this second generation click triazoles. 

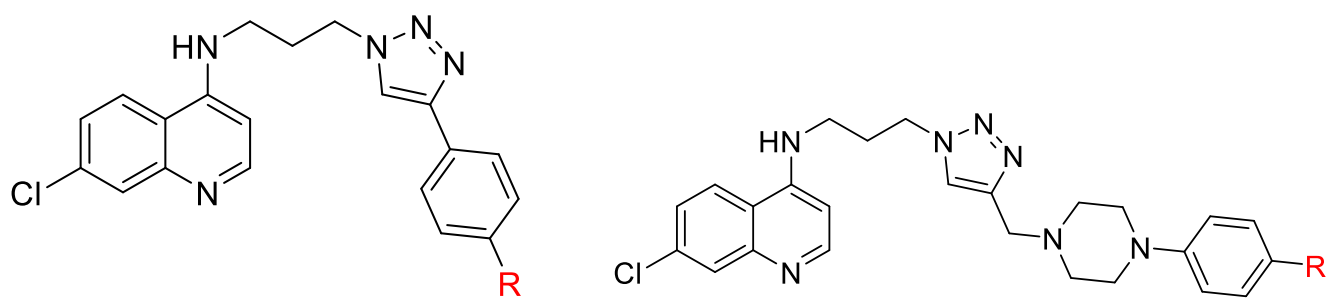

$$
\begin{array}{lll}
\mathrm{R}=\mathrm{CH}_{3}, & \text { PL413 }\left(41^{\mathrm{D} 6}, 61^{\mathrm{Dd} 2}, 60^{7 \mathrm{G} 8}\right) & \text { PL442 }\left(12^{\mathrm{D} 6}, 37^{\mathrm{Dd} 2}, 18^{7 \mathrm{G} 8}\right) \\
\mathrm{R}=\mathrm{CH}_{3} \mathrm{O}, & \text { PL417 }\left(41^{\mathrm{D} 6}, 109^{\mathrm{Dd} 2}, 140^{7 \mathrm{G} 8}\right) & \text { PL444 }\left(33^{\mathrm{D} 6}, 68^{\mathrm{Dd} 2}, 65^{7 \mathrm{G} 8}\right) \\
\mathrm{R}=\mathrm{H}, & \text { PL411 }\left(77^{\mathrm{D} 6}, 88^{\mathrm{Dd} 2}, 151^{7 \mathrm{G} 8}\right) & \text { PL445 }\left(17^{\mathrm{D} 6}, 67^{\mathrm{Dd} 2}, 74^{7 \mathrm{G} 8}\right) \\
\mathrm{R}=\mathrm{Cl}, & \text { PL418 }\left(19^{\mathrm{D} 6}, 43^{\mathrm{Dd} 2}, 37^{7 \mathrm{G} 8}\right) & \text { PL447 }\left(8.8^{\mathrm{D} 6}, 26.5^{\mathrm{Dd} 2}, 19^{7 \mathrm{G} 8}\right)
\end{array}
$$

Figure 4.11. The comparison of the selected first and second generation triazoles for similar substituents

When the electron-donating substituents, methyl and methoxy, were compared, PL442 and PL444 indicated more potency than their respective piperazine omitted counterparts PL413 and PL417 against D6, Dd2 and 7G8 strains. Moreover, PL447, which has an electron-withdrawing chloro-substituent, indicated two-fold activity when compared to PL418. The same trend was observed for the unsubstituted (H-substituted) triazoles against all the three strains (PL411 vs PL445).

In summary, six of the nine synthesized piperazinyl-linked triazoles were found to have more potent activity than chloroquine against CQ-resistant strains of $P$. falciparum. Although none of them showed better activity against CQ-sensitive strain, the para-chloro (PL447) and dichloro (PL448) substituted click compounds exhibited comparable activity with chloroquine with an $\mathrm{IC}_{50}$ values of 8.8 and $6.8 \mathrm{nM}$ respectively (Refer to table 4.5). 


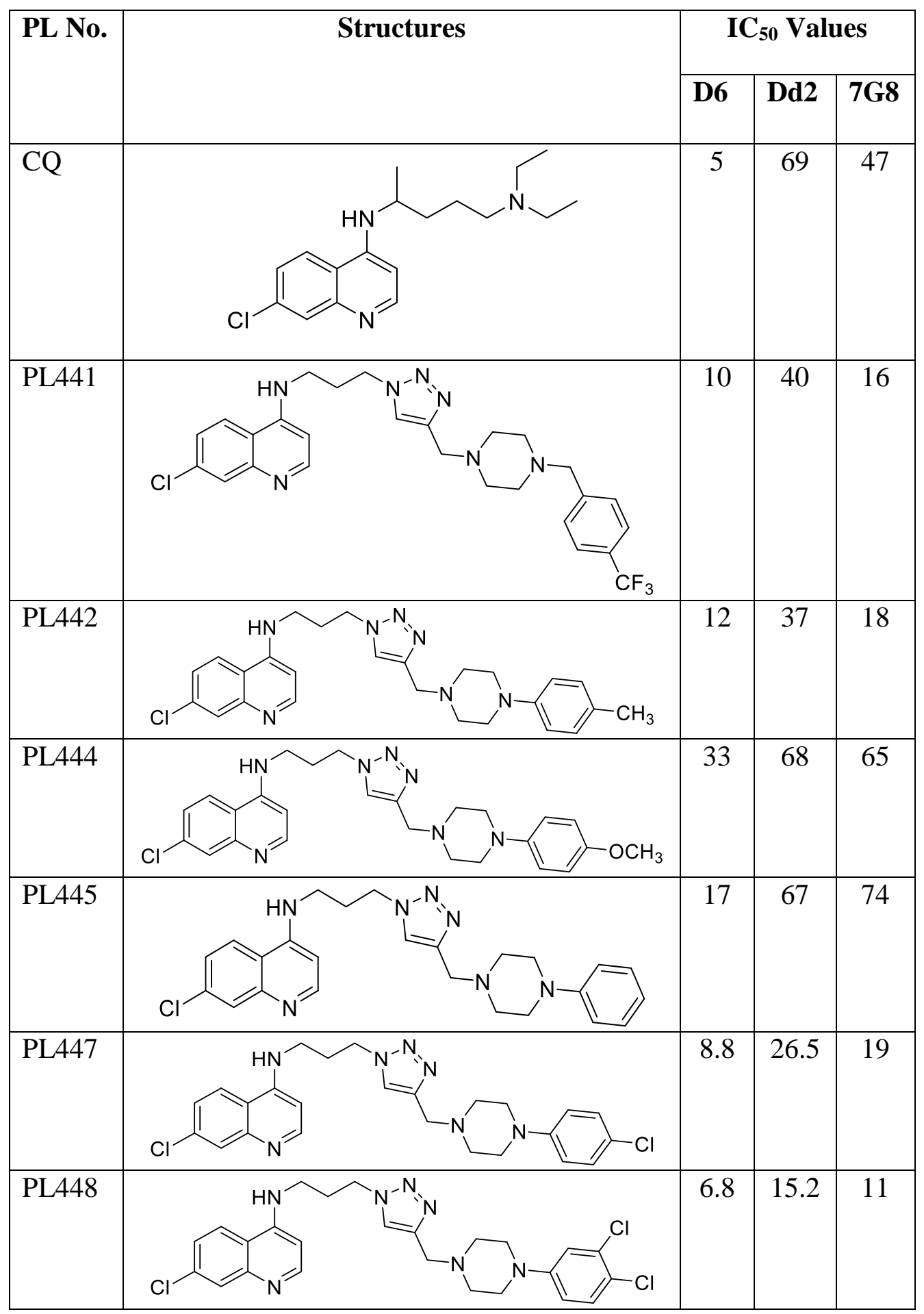

Table 4.5. Selected piperazine containing click compounds having better activity than Chloroquine against CQ-resistant strains 
All the six selected compounds possessed better potency against $\operatorname{Dd} 2$ strain of $P$. falciparum than chloroquine. When tested against 7G8 strain, PL441, PL442, PL447 and PL448 showed enhanced activity but not the para-methoxy (PL444) and the unsubstituted (PL445) triazoles. Generally, the para and di-substitutions with electron-withdrawing groups were found to be beneficial for having better antimalarial activity for these types of piperazine-linked click compounds. PL448 has proved to possess the best activity from all the second generation triazoles.

\subsection{The Activity of Triazole-based Bisquinoline}

The triazole-based bisquinoline, PL456, synthesized by linking two chloroquinoline moieties by triazole ring, was tested for in vitro antimalarial activity against all the three strains of $P$. falciparum. Unlike the other click compounds, it showed excellent activity against CQ-sensitive strain (D6). In addition, PL456 exhibited a potent activity against both CQ-resistant strains (Dd2 and 7G8) when compared to chloroquine.

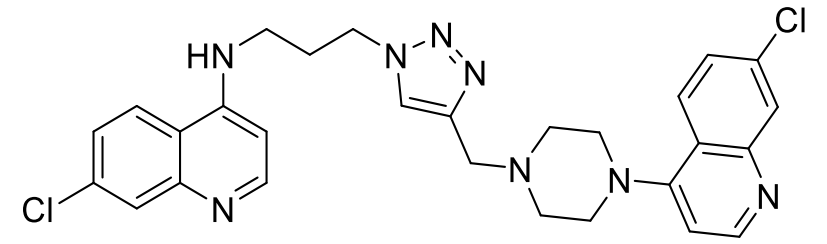

\begin{tabular}{|c|c|c|c|}
\hline \multirow{2}{*}{ Compounds } & \multicolumn{3}{|c|}{ IC $_{\mathbf{5 0}}$ (nM) } \\
\cline { 2 - 4 } & D6 & Dd2 & $\mathbf{7 G 8}$ \\
\hline Chloroquine & 9 & 143 & 127 \\
\hline PL456 & 0.5 & 10 & 11 \\
\hline
\end{tabular}

Table 4.6. The structure and activity of triazole-based bisquinoline 


\section{CHAPTER 5: Reversed Chloroquines}

\subsection{The 6-Aminoquinoline antimalarials}

Although the 4- and 8-quinoline substitutions are very common on the quinoline ring, there are few antimalarials containing functional groups on the 6-position. An electrondonating, methoxy group, is a very common substituent on the 6-position of the quinoline ring. Common antimalarial drugs such as quinine and primaquine all have a methoxy functional group substitution on the 6-position but the main linkers are on the 4- and 8quinoline substitutions respectively.
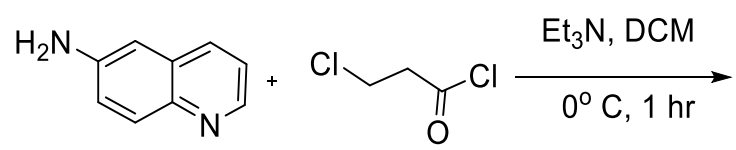<smiles>O=C(CCCl)Nc1ccc2ncccc2c1</smiles>
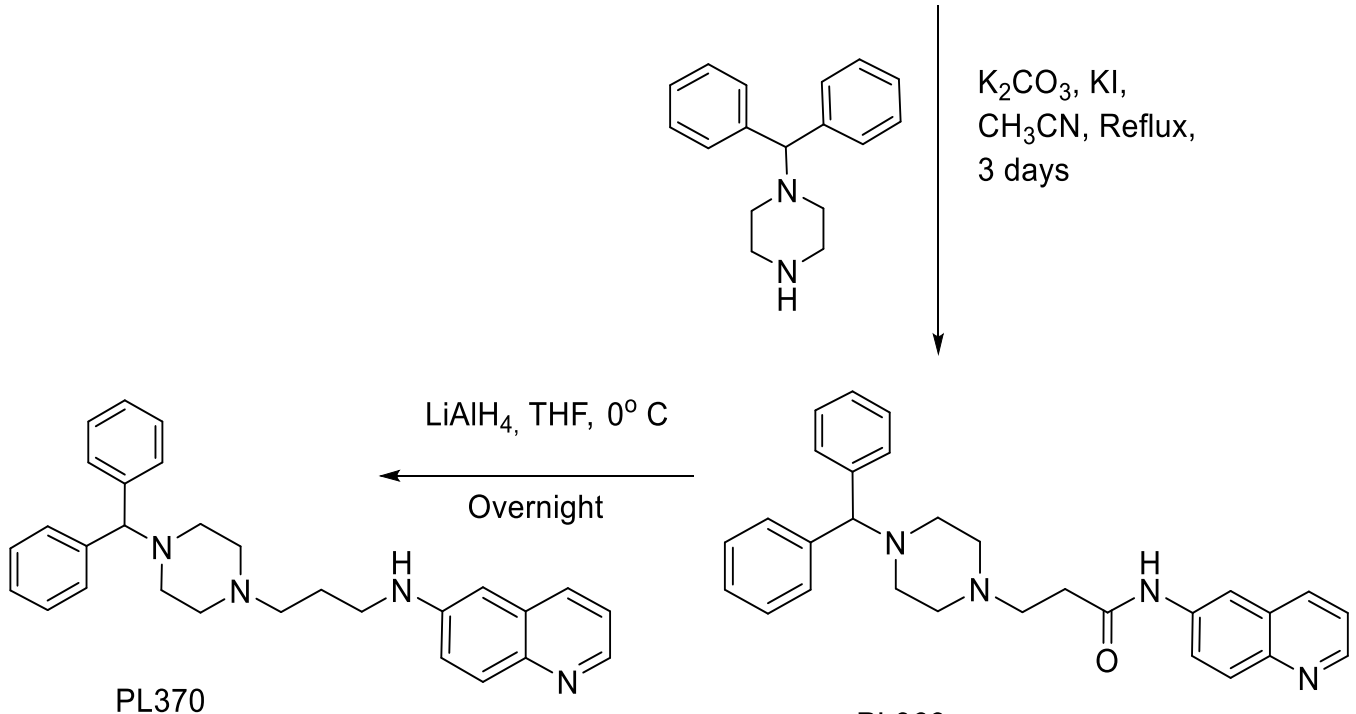

PL369

Scheme 5.1. Synthesis of 6-aminoquinoline antimalarial, PL370 
A reversed quinoline hybrid molecule was synthesized in Peyton lab by linking 6quinoline moiety with benzhydryl-piperazine which has the reversal agent pharmacophore. First, PL323 was prepared by treating 6-aminoquinoline with 3chloropropionyl-chloride in a cold reaction using triethylamine as a base and

dichloromethane as a solvent. ${ }^{116}$ The amide was reacted with benzhydryl-piperazine to form PL369, which is further reduced using $\mathrm{LiAlH}_{4}$ in cold reaction to get the target molecule, PL370 in a good yield.

When tested for antimalarial activity against D6, Dd2 and 7G8 strains of $P$. falciparum, PL370 showed poor antimalarial activty against both CQ-sensitive and CQ-resistant strains with an $\mathrm{IC}_{50}$ value of $>250 \mathrm{~nm}$ when compared to chloroquine.

\subsection{Fluoxetine as Reversal Agent}

Among the common reversal agents, the SSRI antidepresant, fluoxetine which doesn't possess any intrinsic antimalarial activity when used alone, showed to potentiate the effect of chloroquine. Fluoxetine showed to modulate chloroquine resistance of CQresistant W2 clone by $66 \%$ at a concentrations of $500 \mathrm{nM}$ with verapamil showing only $61 \%{ }^{54}$ In other recent studies, fluoxetine showed to reverse both chloroquine and mefloquine resistance against $\mathrm{Dd} 2$ strain of $P$. falciparum although it indicated to be more synergistic with chloroquine than mefloquine. ${ }^{117}$

In addition, fluoxetine has proven to be a highly effective chemosensitizer in multidrug resistance (MDR) for cancer chemotherapy. In vitro, fluoxetine enhanced 10-100 fold cytotoxicity of many anticancer drugs in drug-resistant cells by increasing drug 
accumulation within MDR-cells and inhibiting drug efflux from those cells. In vivo, fluoxetine enhanced 12-fold accumulation of doxorubicin within tumors with unaltered pharmacokinetics. $^{118}$

In other in vitro and in vivo findings, fluoxetine was found to be a chemosensitizer of the multipump type and considered as a fourth-generation chemosensitizer. ${ }^{119}$ Considering the effect of fluoxetine as a better chemosentisizer, reversed chloroquine molecule using fluoxetine as a reversal agent was synthesized in Peyton lab.

The free-base was reacted with PL29 using triethylamine as a base in tetrahydrofuran to give PL410 in moderate yield. The molecule was potent antimalarial and showed about 20 -fold activity when compared to chloroquine. It has an $\mathrm{IC}_{50}$ values of $<2.5 \mathrm{~nm}$ for $\mathrm{Dd} 2$ and 7G8 strains of $P$. falciparum while CQ has 54 and $57 \mathrm{nM}$ respectively.

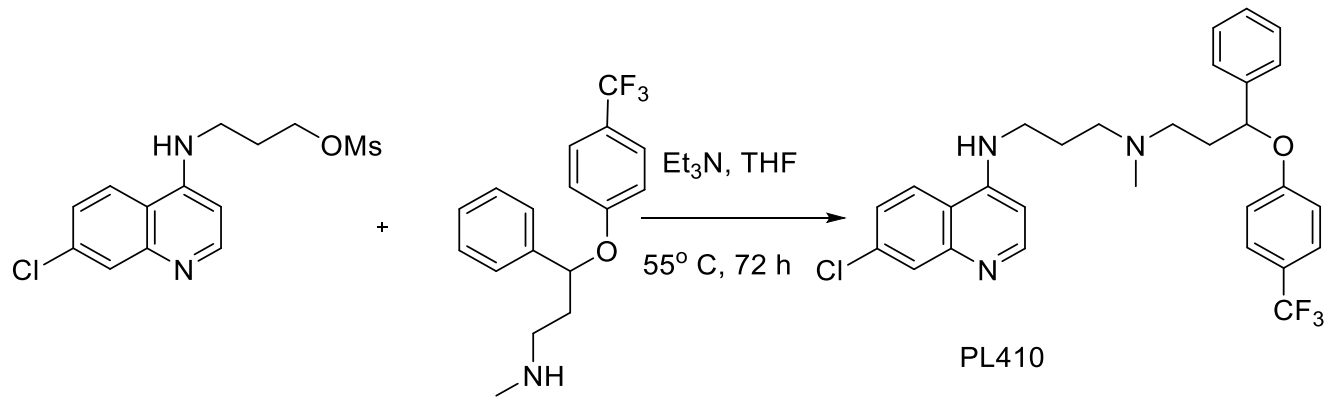

Scheme 5.2. Synthesis of reversed chloroquine using fluoxetine as reversal agent 


\subsection{Meta-substituted Analogue of PL69}

The first hit compound, PL01 which was synthesized as a hybrid drug by using haloquinoline moiety and imipramine as a reversal agent was optimized to increase its hydrophilicity. PL69 was the result of lead optimization that is both potent antimalarial and has better hydrophilicity than the first analogue. In order to see the effect of a substituent on the activity, PL425, which has the nitrogens on the meta positions of the aromatic rings of the reversal agent instead of on the ortho positions was synthesized.

First, 1,8-Diazafluoren-9-one (DFO) was reacted with protected piperidine (Ethyl-4amino-1-piperidine carboxylate) by using catalytic amount of p-toluenesulfonic acid to

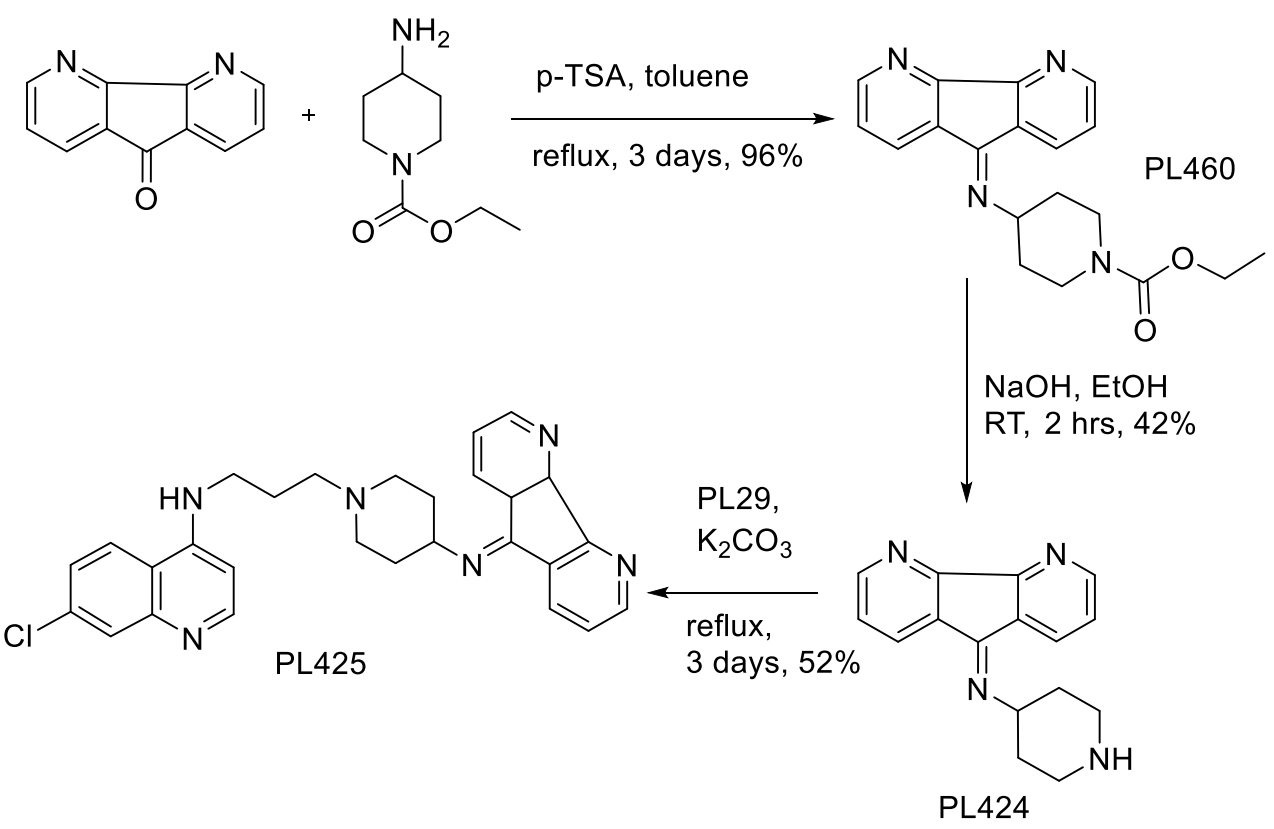

Scheme 5.3. Synthesis of m-substituted analogue of PL69

form PL460 in an excellent yield. The piperidine was deprotected in basic condition by treating with $\mathrm{NaOH}$ in ethanol to prepare the intermediate product PL424. Finally, the 
reversal agent was reacted with PL29 using potassium carbonate base to give the target compound, PL425 in a good yield.

The meta-substituted compound showed better antimalarial activity than CQ, only against $\mathrm{Dd} 2$ strain of $P$. falciparum with an $\mathrm{IC}_{50}$ value $32.5 \mathrm{nM}$ when compared to $54 \mathrm{nM}$ of chloroquine. However, for the D6 and 7G8 strains, PL425 was found to be less active than CQ. 


\section{CHAPTER 6: Summary and Conclusion}

Malaria is considered as one of the most prevalent and debilitating diseases affecting humans. There are 3.4 billion people at risk of malaria transmission with more than half a million deaths, many of them are children. Plasmodium falciparum is the most virulent form and responsible for about $80 \%$ of human malaria worldwide. The plasmodium parasite developed resistance to several antimalarial drugs.

Chloroquine is one of the most successful antimalarials developed that is effective, cheap, and safe to children and pregnant women. However, due to the emergence of drug resistance by $P$. falciparum, its use has been limited. In order to circumvent chloroquine resistance, reversed chloroquines that reverse the resistance by inhibiting the efflux of chloroquine were designed in Peyton lab. These hydrid drugs has been found to be potent against both chloroquine-sensitive and resistant strains of $P$. falciparum both in vitro and in vivo.

It's a challenging task for medicinal chemists to develop new patentable drugs with strong activity and good pharmacokinetic properties in short time. Click chemistry has shown to have a cutting-edge advantage in demanding world of medicinal chemistry in hit finding and lead optimization due to its reliance on extremely quick reactions. Particularly, the copper(I)-catalyzed cycloaddition reaction between azides and terminal alkynes to give 1,4-disubstituted-1,2,3-triazoles has become the benchmark of 'click chemistry' by its reliability, selectivity and biocompatibility. 
The incorporation of 1,2,3-Triazoles into pharmacologically active molecules became more popular after the introduction of copper-catalyzed click chemistry. The stabilty to acid-base hydrolysis, oxidative-reductive conditions and metabolic degradation make triazoles not only good passive linkers but also excellent candidates as pharmacophores and bioisosters. Moreover, these heterocycles readily associate with biological targets via H-bonding and dipole-dipole interactions.

Series of click compounds were synthesized via copper(I)-catalyzed alkyne-azide cycloaddition reaction by modifying the aliphatic chains terminal of chloroquine. Three aliphatic linear chains as linker between the chloroquinoline and the triazole rings were chosen as optimum length both interms of antimalarial activity and hydrophilicity. The 28 antimalarial click compounds were tested for their in vitro activity against D6, Dd2, and $7 \mathrm{G} 8$ strains of $P$. falciparum.

The first 18 click compounds was synthesized by reacting the azide analogue with commercially available terminal alkynes. The first generation click compounds synthesized contain the triazole ring connected directly to one or two aromatic rings with different substitutions. Six of the triazole-based click compunds showed better activity against chloroquine resistant, Dd2 and 7G8, strains of $P$. falciparum. Particularly, PL403 showed about 4 times better activity than chloroquine with an $\mathrm{IC}_{50}$ values of 12.8 and 14.5 nM against CQ-resistant Dd2 and 7G8 strains respectively.

The second generation triazole antimalarials were synthesized by incorporating piperazine ring between the triazole and the p-substituted phenyl ring to have a 
protonable nitrogen which increases the basicity of the molecule. The modification has brought an enhanced antimalarial activity when compared to the first series of compounds. Six of the nine synthesized piperazinyl-linked triazoles were found to have potent activity than chloroquine against CQ-resistant strains. The dichloro substituted triazole, PL448, has proved to possess an excellent activity with $\mathrm{IC}_{50}$ values of 15.2 (Dd2) and 11 (7G8) nM.

In addition to click compounds, other reversed chloroquines were synthesized. A reversed quinoline hybrid molecule was synthesized by linking 6-quinoline moiety with benzhydryl-piperazine as a reversal agent. When tested for antimalarial activity, PL370 showed poor antimalarial activity against all strains of $P$. falciparum. By considering the effect of an SSRI antidepressant, fluoxetine (Prozac), as a very good chemosentisizer in reversing both chloroquine and mefloquine resistance, PL410 was synthesized. This hit was found to be about 20 -fold potent than chloroquine with $\mathrm{IC}_{50}$ values of $<2.5 \mathrm{nM}$ for Dd2 and 7G8 strains of P. falciparum.

In conclusion, the efficiency of synthesizing several triazole-based antimalarials have proven click chemistry to be fast and efficient reaction. Several of the synthesized triazole-based antimalarials possessed better activity against chloroquine resistant strains than chloroquine. Generally, para-substitutions and di-substitutions with short-range and long-range electron-withdrawing groups were found to be beneficial for having better antimalarial activity for these group of click compounds. 


\section{CHAPTER 7: Experimental Materials and Methods}

\subsection{Instrumentation}

All starting chemicals were purchased from Sigma-Aldrich Chemical Co. and TCI America. Nomenclature was done using ChemBioDraw Ultra. Thin layer chromatography was mostly done on Alumina basic column using ethyl-acetate:methanol (90:10) as mobile phase and visualized by UV lamp (254 $\mathrm{nm})$. The purification was commonly done by CombiFlash ${ }^{\circledR}$ Rf-200 chromatography using silica column at UV absorbance of 254 and $280 \mathrm{nM}$ with solid loading, and collecting only the peaks. The eluents used are chloroform:methanol (90:10) for target compunds and hexane:ethylacetate for intermediate compounds.

The compounds were characterized by NMR and Mass spectroscopy. ${ }^{1} \mathrm{H}-,{ }^{13} \mathrm{C}-$, COSY, HSQC, HMBC and NOESY experiments were run on Bruker $400 \mathrm{MHz}$ instrument, using the standard pulse sequences provided at $25^{\circ} \mathrm{C}$. High resolution mass spectrometry was performed on Bruker micrOTOF-Q instrument. Results were obtained using electospray ionization (ESI) in the positive mode, at a flow rate of $0.4 \mathrm{~mL} / \mathrm{min}$ with methanol or acetonitrile.

\subsection{General Synthetic Procedures}

\section{PL16 (3-((7-chloroquinolin-4-yl)amino)propan-1-ol)}

Purified 4,7-dichloroquinoline (1eq, 5 g, $25.2 \mathrm{mmol}$ ) and 3-amino-1-propanol (12.3 eq, $23.7 \mathrm{ml}, 309.9 \mathrm{mmol}$ ) was healted slowly for 1 hour at $70^{\circ} \mathrm{C}$ and the temperature was 
increased to $135^{\circ} \mathrm{C}$ and stirred for 7 additional hours. After the completion was confirmed by TLC, the reaction mixture was poured to ice-cold $\mathrm{H}_{2} \mathrm{O}(100 \mathrm{ml})$. The white precipitate formed was filtered by vaccum filtration, washed with water and dried. After drying, the solid was recrystallized using EtOAC (50ml). The solution was filtered, and after cooling down, vaccum-filtered and washed with water to give pure, white-yellowish solid (5.02 g, 84\%). ${ }^{1} \mathrm{H}$ NMR (400 MHz, DMSO-d6) $\delta 8.39$ (d, J = 5.5 Hz, 1H), 8.25 (d, J $=9.0 \mathrm{~Hz}, 1 \mathrm{H}), 7.78(\mathrm{~d}, \mathrm{~J}=2.2 \mathrm{~Hz}, 1 \mathrm{H}), 7.44(\mathrm{dd}, \mathrm{J}=9.0,2.3 \mathrm{~Hz}, 1 \mathrm{H}), 7.30(\mathrm{t}, \mathrm{J}=5.4 \mathrm{~Hz}$, $1 \mathrm{H}), 6.48(\mathrm{~d}, \mathrm{~J}=5.4 \mathrm{~Hz}, 1 \mathrm{H}), 3.55(\mathrm{t}, \mathrm{J}=6.2 \mathrm{~Hz}, 2 \mathrm{H}), 3.39-3.28(\mathrm{~m}, 7 \mathrm{H}), 1.88-1.76$ $(\mathrm{m}, 2 \mathrm{H})$.

\section{PL28 (2-((7-chloroquinolin-4-yl)amino)ethan-1-ol)}

A mixture of purified 4,7-dichloroquinoline (1 eq, $5 \mathrm{~g}, 25.25 \mathrm{mmol}$ ) and ethanolamine (10 eq, $15.24 \mathrm{ml}, 252.5 \mathrm{mmol}$ ) was heated with stirring overnight at $130{ }^{\circ} \mathrm{C}$. After the reaction mixture was cooled to $\mathrm{RT}$, it was poured to pre-cooled water $(150 \mathrm{ml})$. The white precipitate formed was filtered and dried. After drying, the solid was recrystallized by methanol (100 ml), cooled in ice and filtered by vaccum-filtration to give a pure white solid (4.48 g, $80 \%) . ~{ }^{1} \mathrm{H}$ NMR (600 MHz, DMSO-d6) $\delta 8.39(\mathrm{~d}, \mathrm{~J}=5.4 \mathrm{~Hz}, 1 \mathrm{H}), 8.27$ (d, $\mathrm{J}=9.0 \mathrm{~Hz}, 1 \mathrm{H}), 7.79(\mathrm{~d}, \mathrm{~J}=2.3 \mathrm{~Hz}, 1 \mathrm{H}), 7.45(\mathrm{dd}, \mathrm{J}=9.0,2.4 \mathrm{~Hz}, 1 \mathrm{H}), 7.27(\mathrm{t}, \mathrm{J}=5.6$ $\mathrm{Hz}, 1 \mathrm{H}), 6.50(\mathrm{~d}, \mathrm{~J}=5.5 \mathrm{~Hz}, 1 \mathrm{H}), 3.67(\mathrm{t}, \mathrm{J}=6.1 \mathrm{~Hz}, 2 \mathrm{H}), 3.36(\mathrm{q}, \mathrm{J}=5.8 \mathrm{~Hz}, 2 \mathrm{H})$.

\section{PL29 (3-((7-chloroquinolin-4-yl)amino)propyl methanesulfonate)}

To a suspension of PL16 (1 eq, $5 \mathrm{~g}, 21.2 \mathrm{mmol})$ in anhydrous THF (100ml) stirring under $\mathrm{N}_{2}$ and cooled in an ice-bath, triethylamine (2 eq, $5.9 \mathrm{ml}, 42.3 \mathrm{mmol}$ ) was added. After 
the mixture was cooled to $0{ }^{\circ} \mathrm{C}$, methane-sulfonyl chloride $(1.3 \mathrm{eq}, 2.13 \mathrm{ml}, 27.6 \mathrm{mmol})$ was added very slowly keeping the temperature below $10{ }^{\circ} \mathrm{C}$ and the reaction was stirred for 1 hour. After the completion was confirmed by TLC, work-up was done by liquidliquid extraction by adding saturated $\mathrm{NaHCO}_{3}(100 \mathrm{ml})$. After separating the organic layer, the aqueous layer was extracted with diethyl-ether $(200 \mathrm{ml}$ and then $2 * 100 \mathrm{ml})$. The orgainic layers were mixed and dried by anhydrous $\mathrm{MgSO}_{4}$, concentrated by rotovap and dried to give white-yellowish solid (5.4 g, 82\%). ${ }^{1} \mathrm{H}$ NMR (400 MHz, DMSO-d6) $\delta 8.43$ $(\mathrm{d}, \mathrm{J}=5.3 \mathrm{~Hz}, 1 \mathrm{H}), 8.28(\mathrm{~d}, \mathrm{~J}=9.0 \mathrm{~Hz}, 1 \mathrm{H}), 7.82(\mathrm{~d}, \mathrm{~J}=2.2 \mathrm{~Hz}, 1 \mathrm{H}), 7.48(\mathrm{dd}, \mathrm{J}=9.0$, $2.3 \mathrm{~Hz}, 1 \mathrm{H}), 7.36(\mathrm{t}, \mathrm{J}=5.5 \mathrm{~Hz}, 1 \mathrm{H}), 6.52(\mathrm{~d}, \mathrm{~J}=5.4 \mathrm{~Hz}, 1 \mathrm{H}), 4.37(\mathrm{t}, \mathrm{J}=6.2 \mathrm{~Hz}, 2 \mathrm{H})$, $3.51-3.33(\mathrm{~m}, 2 \mathrm{H}), 3.21(\mathrm{~s}, 3 \mathrm{H}), 2.10(\mathrm{p}, \mathrm{J}=6.5 \mathrm{~Hz}, 2 \mathrm{H})$.

\section{PL30 (2-((7-chloroquinolin-4-yl)amino)ethyl methanesulfonate)}

PL28 (1 eq, $5 \mathrm{~g}, 22.5 \mathrm{mmol})$ was dissolved in dry acetone $(100 \mathrm{ml})$ and triethylamine (1.5 eq, $4.7 \mathrm{ml}, 33.7 \mathrm{mmol}$ ) was added. The mixture was chilled to $0{ }^{\circ} \mathrm{C}$ in an ice-bath and the reaction was carried under $\mathrm{N}_{2}$. Methane-sulfonylchloride (1.2 eq, $2.1 \mathrm{ml}, 27 \mathrm{mmol}$ ) was added drop-wise keeping the temperature below $10{ }^{\circ} \mathrm{C}$. The reaction was continued to run with stirring for 5 hours. After the completion, the solid was filtered and the solvent was evaporated. The two solids were combined and washed by saturated $\mathrm{NaHCO}_{3}(100 \mathrm{ml})$. The orgainic layer was dried by anhydrous $\mathrm{MgSO}_{4}$, filtered and concentrated to give white solid (5.8 g, 85\%). ${ }^{1} \mathrm{H}$ NMR (400 MHz, DMSO-d6) $\delta 8.44(\mathrm{~d}, \mathrm{~J}=5.4 \mathrm{~Hz}, 1 \mathrm{H}), 8.26$ $(\mathrm{d}, \mathrm{J}=9.0 \mathrm{~Hz}, 1 \mathrm{H}), 7.85-7.76(\mathrm{~m}, 1 \mathrm{H}), 7.55-7.43(\mathrm{~m}, 2 \mathrm{H}), 6.60(\mathrm{~d}, \mathrm{~J}=5.5 \mathrm{~Hz}, 1 \mathrm{H})$, $4.44(\mathrm{t}, \mathrm{J}=5.4 \mathrm{~Hz}, 2 \mathrm{H}), 3.68(\mathrm{q}, \mathrm{J}=5.4 \mathrm{~Hz}, 2 \mathrm{H}), 3.17(\mathrm{~s}, 3 \mathrm{H})$. 


\section{PL49 (7-chloro-4-(piperazin-1-yl)quinoline)}

4,7-dichloroquinline (1 eq, $2.5 \mathrm{~g}, 12.62 \mathrm{mmol}$ ) and anhydrous piperazine (7 eq, $7.6 \mathrm{~g}$, $88.36 \mathrm{mmol})$ were refluxed in ethanol $(37.5 \mathrm{ml})$ for 12 hours. After completion, the solvent was evaporated and the solid was dissolved in dichloromethane $(50 \mathrm{ml})$. The solution was washed with saturated $\mathrm{NaHCO}_{3}(4 * 25 \mathrm{ml})$. Finally the organic layer was separated, dried by anhydrous $\mathrm{MgSO}_{4}$, filtered and concentrated. The compound was pure enough to be used in the next step without purification $(2.62 \mathrm{~g}, 84 \%) .{ }^{1} \mathrm{H}$ NMR (400 $\left.\mathrm{MHz}, \mathrm{CDCl}_{3}\right) \delta 8.72(\mathrm{~d}, \mathrm{~J}=5.0 \mathrm{~Hz}, 1 \mathrm{H}), 8.03(\mathrm{~d}, \mathrm{~J}=2.1 \mathrm{~Hz}, 1 \mathrm{H}), 7.95(\mathrm{~d}, \mathrm{~J}=8.9 \mathrm{~Hz}$, 1H), $7.42(\mathrm{dd}, \mathrm{J}=9.0,2.1 \mathrm{~Hz}, 1 \mathrm{H}), 6.83(\mathrm{~d}, \mathrm{~J}=5.0 \mathrm{~Hz}, 1 \mathrm{H}), 3.23-3.12(\mathrm{~m}, 9 \mathrm{H}), 1.79(\mathrm{~s}$ $1 \mathrm{H}, \mathrm{NH})$.

\section{PL107 (N ${ }^{1}$-(7-chloroquinolin-4-yl)propane-1,3-diamine)}

4,7-dichloroquinoline (1 eq, $2.3 \mathrm{~g}, 11.61 \mathrm{mmols})$ and 1,3-diaminopropane (4.4 eq, 4.27 $\mathrm{ml}, 51.1 \mathrm{mmols})$ were stirred neatly for 1.5 hours at $80{ }^{\circ} \mathrm{C}$ and 6 hours at $145{ }^{\circ} \mathrm{C}$. After the completion of the reaction was confirmed by TLC, it was cooled to room temperature. $\mathrm{NaOH}(10 \%, 7.2 \mathrm{ml})$ was added and the mixture was stirred on a sonicator. The precipitate was filtered by vaccum-filtration and washed with excess water and dried to give white solid (2.5 g, $91 \%) .{ }^{1} \mathrm{H}$ NMR (400 MHz, DMSO-d6) $\delta 8.38(\mathrm{t}, \mathrm{J}=5.3 \mathrm{~Hz}, 1 \mathrm{H})$, $8.27(\mathrm{dd}, \mathrm{J}=21.6,9.1 \mathrm{~Hz}, 1 \mathrm{H}), 7.78(\mathrm{~d}, \mathrm{~J}=2.3 \mathrm{~Hz}, 1 \mathrm{H}), 7.44(\mathrm{ddd}, \mathrm{J}=8.8,6.1,2.3 \mathrm{~Hz}$ 1H), $6.49(\mathrm{dd}, \mathrm{J}=16.2,5.4 \mathrm{~Hz}, 1 \mathrm{H}), 3.43(\mathrm{q}, \mathrm{J}=6.4 \mathrm{~Hz}, 1 \mathrm{H}), 3.33(\mathrm{t}, \mathrm{J}=6.9 \mathrm{~Hz}, 2 \mathrm{H})$, $3.07(\mathrm{~s}, 2 \mathrm{H}), 2.70(\mathrm{t}, \mathrm{J}=6.5 \mathrm{~Hz}, 2 \mathrm{H}), 1.75(\mathrm{p}, \mathrm{J}=6.7 \mathrm{~Hz}, 2 \mathrm{H})$. 


\section{PL190 (N-(piperidin-4-yl)-1,1-di(pyridin-2-yl)methanimine)}

2, 2'-dipyridyl-ketone (1 eq, $3.0 \mathrm{~g}, 16.3 \mathrm{mmol})$ was dissolved in toluene (70 ml). 4aminopiperidine (1.15 eq, $1.98 \mathrm{ml}, 18.7 \mathrm{mmol})$ was added, followed by $\mathrm{p}$ toluenesulfonic-acid $(0.1 \mathrm{~g})$. The reaction was refluxed while stirring and using deanstark apparatus to continuously remove the water by-product. After the completion of the reaction, the solvent was evaporated and purified by combi-flash chromatography on silica column (1.27 g, $29 \%) .{ }^{1} \mathrm{H}$ NMR (400 MHz, Chloroform-d) $\delta 8.72(\mathrm{dt}, \mathrm{J}=5.0,1.3$ $\mathrm{Hz}, 1 \mathrm{H}), 8.55-8.46(\mathrm{~m}, 1 \mathrm{H}), 8.15(\mathrm{dt}, \mathrm{J}=8.0,1.2 \mathrm{~Hz}, 1 \mathrm{H}), 7.77(\mathrm{dtd}, \mathrm{J}=26.2,7.8,1.8$ $\mathrm{Hz}, 2 \mathrm{H}), 7.38-7.09(\mathrm{~m}, 3 \mathrm{H}), 3.39(\mathrm{tt}, \mathrm{J}=9.4,4.5 \mathrm{~Hz}, 1 \mathrm{H}), 3.18-3.02(\mathrm{~m}, 2 \mathrm{H}), 2.79-$ $2.48(\mathrm{~m}, 2 \mathrm{H}), 1.87-1.65(\mathrm{~m}, 4 \mathrm{H})$.

\section{PL294 (7-chloro-N-(piperidin-4-yl)quinolin-4-amine)}

4,7-dichloroquinoline (1 eq, $5 \mathrm{~g}, 25 \mathrm{mmol}$ ) and 4-aminopiperidine (5 eq, $13.4 \mathrm{ml}, 126$ mmol) in N,N-diisopropylethylamine $(100 \mathrm{ml})$ was heated at $100{ }^{\circ} \mathrm{C}$ for 20 hours. The DIPEA was evaporated and the crude was purified by combi-flash chromatography in silica column and using DCM:MeOH:Et ${ }_{3} \mathrm{~N}(8.9: 1: 0.1)$ as eluents to give a pure solid (3.10 g, $47 \%) .{ }^{1} \mathrm{H}$ NMR (400 MHz, $\left.\mathrm{CDCl}_{3}\right): \delta 8.62(\mathrm{~d}, \mathrm{~J}=5.2,1 \mathrm{H}), 7.96(\mathrm{~d}, \mathrm{~J}=2.0$, 1H), $7.85(\mathrm{~d}, \mathrm{~J}=8.9,1 \mathrm{H}), 7.35(\mathrm{dd}, \mathrm{J}=8.9,2.0,1 \mathrm{H}), 6.75(\mathrm{~d}, \mathrm{~J}=5.2,1 \mathrm{H}), 5.24(\mathrm{~s}, 1 \mathrm{H})$, $3.48(\mathrm{~d}, \mathrm{~J}=12.0,2 \mathrm{H}), 2.89(\mathrm{~m}, 1 \mathrm{H}), 2.82(\mathrm{t}, \mathrm{J}=11.6,2 \mathrm{H}), 1.97(\mathrm{~d}, \mathrm{~J}=12.0,2 \mathrm{H}), 1.61$ $(\mathrm{m}, 4 \mathrm{H})$. 


\section{PL323 (3-chloro-N-(quinolin-6-yl)propanamide)}

6-aminoquinoline (1 eq, $5.0 \mathrm{~g}, 34.68 \mathrm{mmol})$ and triethylamine $(1.2 \mathrm{eq}, 5.8 \mathrm{ml}, 41.62$ mmols) were mixed in anhydrous dichloromethane $(40 \mathrm{ml})$ on ice-bath. 3Chloropropionyl-chloride (1.05 eq, $3.47 \mathrm{ml}, 36.41 \mathrm{mmols})$ was added dropwise keeping the temperature below $10{ }^{\circ} \mathrm{C}$. The reaction was stirred for 1 hour. Saturated $\mathrm{NaHCO}_{3}(25$ $\mathrm{ml}$ ) was added and the aqueous layer was extracted by dichloromethane $(3 * 10 \mathrm{ml})$. The organic layer was dried by anhydrous $\mathrm{MgSO}_{4}$, filtered and dried. The crude was purified by combi-flash chromatography using silica column and EtOAC:MeOH as eluents to

give a yellow solid (2.49 g, $50 \%$ ). ${ }^{1} \mathrm{H}$ NMR (400 MHz, Chloroform-d) $\delta{ }^{1} \mathrm{H}$ NMR (400 MHz, DMSO-d6) $\delta 10.66(\mathrm{~s}, 1 \mathrm{H}), 8.81(\mathrm{dd}, \mathrm{J}=4.2,1.7 \mathrm{~Hz}, 1 \mathrm{H}), 8.41-8.29(\mathrm{~m}, 2 \mathrm{H})$, $8.00(\mathrm{~d}, \mathrm{~J}=9.0 \mathrm{~Hz}, 1 \mathrm{H}), 7.81(\mathrm{dd}, \mathrm{J}=9.1,2.4 \mathrm{~Hz}, 1 \mathrm{H}), 7.50(\mathrm{dd}, \mathrm{J}=8.3,4.2 \mathrm{~Hz}, 1 \mathrm{H})$, $3.93(\mathrm{t}, \mathrm{J}=6.3 \mathrm{~Hz}, 2 \mathrm{H}), 2.90(\mathrm{t}, \mathrm{J}=6.3 \mathrm{~Hz}, 2 \mathrm{H})$.

\section{PL326 (N-(3-chloropropyl)quinolin-6-amine)}

PL323 (1 eq, $1.87 \mathrm{~g}, 7.97 \mathrm{mmol}$ ) was dissolved in tetrahydrofuran (20ml). $\mathrm{LiAlH}_{4}$ in $1 \mathrm{M}$ THF (3eq, 23.9ml, $23.9 \mathrm{mmol}$ ) was slowly added under $\mathrm{N}_{2}$ in an ice-bath. An additional $30 \mathrm{ml}$ of THF was added and the reaction was allowed to stir overnight . After completion was confirmed by TLC, the reaction mixture was quenched with EtOAc (20ml) and $\mathrm{MeOH}(20 \mathrm{ml})$, and then by citric acid solution. After filtering the yellow precipitate, the solution was extracted using diethyl-ether $(2 * 20 \mathrm{ml})$. The organic layer was separated, dried by anhydrous $\mathrm{MgSO}_{4}$, filtered and concentrated to get a brownish-oily compound (1.01g, 57.4\%). ${ }^{1} \mathrm{H}$ NMR (400 MHz, Chloroform-d) $\delta 8.61-8.53$ (m, 1H), $7.94-7.87$ 
$(\mathrm{m}, 1 \mathrm{H}), 7.84(\mathrm{~d}, \mathrm{~J}=9.1 \mathrm{~Hz}, 1 \mathrm{H}), 7.23(\mathrm{dt}, \mathrm{J}=8.3,4.2 \mathrm{~Hz}, 1 \mathrm{H}), 7.06(\mathrm{dd}, \mathrm{J}=9.1,2.6 \mathrm{~Hz}$, $1 \mathrm{H}), 6.66(\mathrm{dd}, \mathrm{J}=8.0,2.6 \mathrm{~Hz}, 1 \mathrm{H}), 3.17(\mathrm{t}, \mathrm{J}=7.2 \mathrm{~Hz}, 2 \mathrm{H}), 1.72-1.66(\mathrm{~m}, 2 \mathrm{H}), 1.04(\mathrm{t}$, $\mathrm{J}=7.4 \mathrm{~Hz}, 2 \mathrm{H})$.

\section{PL334 (2-chloro-N-(quinolin-6-yl)acetamide)}

6-aminoquinoline (1 eq, $1.0 \mathrm{~g}, 6.94 \mathrm{mmol})$ and triethylamine $(1.2 \mathrm{eq}, 1.16 \mathrm{ml}, 14.15$ mmols) were mixed in anhydrous dichloromethane $(40 \mathrm{ml})$ on ice-bath. Chloroacetylchloride (1.05 eq, $0.58 \mathrm{ml}, 7.29 \mathrm{mmols})$ was added dropwise keeping the temperature below $10^{\circ} \mathrm{C}$. The reaction was stirred for 1 hour. Saturated $\mathrm{NaHCO}_{3}(25 \mathrm{ml})$ was added and the aqueous layer was extracted by DCM $(3 * 10 \mathrm{ml})$. The organic layer was dried by anhydrous $\mathrm{MgSO}_{4}$, filtered and dried. The crude was purified by combiflash chromatography using silica column and EtOAC:MeOH as eluents to give a pure solid (1.10 g, $66 \%) .{ }^{1} \mathrm{H}$ NMR (400 MHz, Chloroform-d) $\delta 8.87(\mathrm{dd}, \mathrm{J}=4.2,1.7 \mathrm{~Hz}, 1 \mathrm{H})$, $8.53(\mathrm{~s}, 1 \mathrm{H}), 8.35(\mathrm{~d}, \mathrm{~J}=2.4 \mathrm{~Hz}, 1 \mathrm{H}), 8.18-8.13(\mathrm{~m}, 1 \mathrm{H}), 8.10(\mathrm{~d}, \mathrm{~J}=9.0 \mathrm{~Hz}, 1 \mathrm{H}), 7.65$ $(\mathrm{dd}, \mathrm{J}=9.0,2.5 \mathrm{~Hz}, 1 \mathrm{H}), 7.42(\mathrm{dd}, \mathrm{J}=8.3,4.2 \mathrm{~Hz}, 1 \mathrm{H}), 4.26(\mathrm{~s}, 2 \mathrm{H})$.

\section{PL369 (3-(4-benzhydrylpiperazin-1-yl)-N-(quinolin-6-yl)propanamide)}

PL323 (1eq, 2.0g, $8.53 \mathrm{mmol})$ was dissolved in acetonitrile $(40 \mathrm{ml})$. 1benzhydrylpiperazine (1.05 eq, $2.26 \mathrm{~g}, 8.96 \mathrm{mmol})$, anhydrous $\mathrm{K}_{2} \mathrm{CO}_{3}(2.4 \mathrm{eq}, 2.97 \mathrm{~g}$, $21.50 \mathrm{mmol}$ ) and KI (1 eq, $1.42 \mathrm{~g}, 8.53 \mathrm{mmol})$ were all added to the solution. The reaction was refluxed with stirring for 3 days. After completion was confirmed, the acetonitrile solvent was evaporated and the slurry was taken up by EtOAC $(20 \mathrm{ml})$ and water $(40 \mathrm{ml})$. The aqueous phase was extracted by EtOAC $(2 * 10 \mathrm{ml})$ and the organic 
layer was washed with saturated $\mathrm{NaHCO}_{3}(15 \mathrm{ml})$, and then washed with brine $(20 \mathrm{ml})$. The organic layer was dried by anhydrous $\mathrm{MgSO}_{4}$, filtered and concentrated. The crude was purified by combi-flash chromatography using silica column and and EtOAC:MeOH $(85: 15)$ as eluents to give a yellowish solid (1.6 g, $80 \%) .{ }^{1} \mathrm{H}$ NMR (400 MHz, Chloroform-d) $\delta 11.41(\mathrm{~s}, 1 \mathrm{H}), 8.81(\mathrm{dd}, \mathrm{J}=4.3,1.7 \mathrm{~Hz}, 1 \mathrm{H}), 8.44(\mathrm{~d}, \mathrm{~J}=2.3 \mathrm{~Hz}, 1 \mathrm{H})$, $8.14-8.09(\mathrm{~m}, 1 \mathrm{H}), 8.02(\mathrm{~d}, \mathrm{~J}=9.0 \mathrm{~Hz}, 1 \mathrm{H}), 7.48-7.43(\mathrm{~m}, 4 \mathrm{H}), 7.41-7.34(\mathrm{~m}, 2 \mathrm{H})$, $7.31(\mathrm{dd}, \mathrm{J}=8.3,6.8 \mathrm{~Hz}, 4 \mathrm{H}), 7.25-7.19(\mathrm{~m}, 2 \mathrm{H}), 4.38(\mathrm{~s}, 1 \mathrm{H}), 2.50-2.81$ (ddd, $\mathrm{J}=80.7$, 7.0, 5.2 Hz, 8H). ${ }^{13} \mathrm{C}$ NMR (101 MHz, Chloroform-d) $\delta 171.0,149.1,145.3,142.1$, $136.6,135.9,130.1,128.6,128.0,127.2,123.1,121.5,115.6,75.9,53.6,52.6,52.0,32.5$. $\mathrm{m} / \mathrm{z} 450.25 \mathrm{M}+\mathrm{H}$ (calculated 450.59).

\section{PL370 (N-(3-(4-benzhydrylpiperazin-1-yl)propyl)quinolin-6-amine)}

PL369 (1 eq, $1.6 \mathrm{~g}, 3.66 \mathrm{mmol}$ ) was dissolved in tetrahydrofuran (20 ml). Under $\mathrm{N}_{2}$, $\mathrm{LiAlH}_{4}$ in $2.5 \mathrm{M}$ THF (5 eq, $7.33 \mathrm{ml}, 18.31 \mathrm{mmol}$ ) was added into the reaction mixture. The reaction was allowed to run at $0{ }^{\circ} \mathrm{C}$ overnight. After completion, the solution was quenched by citric acid solution. To the yellow-greenish suspension formed, $\mathrm{NaOH}(2.75$ M, $1 \mathrm{ml})$ and saturated $\mathrm{NaHCO}_{3}(20 \mathrm{ml})$ was added, and the aqueous phase was extracted with diethylether $(2 * 15 \mathrm{ml})$. The organic phase was washed with water $(10 \mathrm{ml})$ and salted out with brine $(10 \mathrm{ml})$. Finally, the organic layer was dried by anhydrous $\mathrm{MgSO}_{4}$, filtered and evaporated to give a brownish, oily solid. The crude $(0.76 \mathrm{~g})$ was purified by combi-flash chromatography by dissolving in acetone and small amount of methanol. Silica gel sorbent $(7.6 \mathrm{~g})$ was added and the suspension was stirred on sonicator before evaporating the solvent. The solid was purified in silica column (40 g) using 
EtOAC:MeOH (85:15) as eluents by collecting only the peaks for 20 minutes twice (0.42 g, $56 \%) .{ }^{1} \mathrm{H}$ NMR (400 MHz, Chloroform-d) $\delta 8.58(\mathrm{dd}, \mathrm{J}=4.3,1.7 \mathrm{~Hz}, 1 \mathrm{H}), 7.91-$ $7.81(\mathrm{~m}, 2 \mathrm{H}), 7.47-7.39(\mathrm{~m}, 4 \mathrm{H}), 7.32-7.15(\mathrm{~m}, 8 \mathrm{H}), 7.02(\mathrm{dd}, \mathrm{J}=9.1,2.6 \mathrm{~Hz}, 1 \mathrm{H})$, $6.62(\mathrm{~d}, \mathrm{~J}=2.6 \mathrm{~Hz}, 1 \mathrm{H}), 4.28(\mathrm{~s}, 1 \mathrm{H}), 3.26(\mathrm{t}, \mathrm{J}=6.2 \mathrm{~Hz}, 2 \mathrm{H}), 2.61-2.34(\mathrm{~m}, 10 \mathrm{H}), 1.84$ $(\mathrm{p}, \mathrm{J}=6.3 \mathrm{~Hz}, 2 \mathrm{H}) .{ }^{13} \mathrm{C}$ NMR (101 MHz, Chloroform-d) $\delta$ 149.1, 145.3, 142.1, 136.6, $135.9,130.1,128.6,128.0,127.2,123.1,121.5,115.6,75.9,53.6,52.6,52.0,41.1,32.5$. $\mathrm{m} / \mathrm{z} 436.27 \mathrm{M}+\mathrm{H}$ (calculated 436.60).

\section{PL403 (7-chloro-N-(3-(4-(4-(trifluoromethoxy)phenyl)-1H-1,2,3-triazol-1-} yl)propyl)quinolin-4-amine)

To a stirred solution of PL409 (1 $\quad$ eq, $0.16 \quad \mathrm{~g}, \quad 0.61 \quad \mathrm{mmol}), \quad 4-$ (trifluoromethoxy)phenylacetylene (1.07 eq, $0.1 \mathrm{ml}, 0.65 \mathrm{mmol})$ in tert-butanol $(7 \mathrm{ml})$, was added a solution of $\mathrm{CuSO}_{4} .5 \mathrm{H}_{2} \mathrm{O}(0.2 \mathrm{eq}, 0.030 \mathrm{~g}, 0.12 \mathrm{mmol})$ and sodium ascorbate ( $0.4 \mathrm{eq}, 0.048 \mathrm{~g}, 0.24 \mathrm{mmol})$ in water $(7 \mathrm{ml})$, and the mixture was stirred for 4 hours at 40 ${ }^{\circ} \mathrm{C}$. After completion, $\mathrm{CHCl}_{3}(20 \mathrm{ml})$ was added and the mixture was washed with water $(2 * 100 \mathrm{ml})$. Finally the organic layer was dried by anhydrous $\mathrm{MgSO}_{4}$, filtered and concentrated to give a white solid $(0.08 \mathrm{~g}, 30 \%) .{ }^{1} \mathrm{H}$ NMR (400 MHz, DMSO-d6) $\delta 8.68$ (s, 1H), $8.41(\mathrm{~s}, 1 \mathrm{H}), 8.26(\mathrm{~d}, \mathrm{~J}=9.0 \mathrm{~Hz}, 1 \mathrm{H}), 7.99-7.90(\mathrm{~m}, 2 \mathrm{H}), 7.79(\mathrm{~s}, 1 \mathrm{H}), 7.50-$ $7.41(\mathrm{~m}, 3 \mathrm{H}), 7.36(\mathrm{t}, \mathrm{J}=5.4 \mathrm{~Hz}, 1 \mathrm{H}), 6.49(\mathrm{~d}, \mathrm{~J}=4.9 \mathrm{~Hz}, 1 \mathrm{H}), 4.58(\mathrm{t}, \mathrm{J}=6.9 \mathrm{~Hz}, 2 \mathrm{H})$, $3.37(\mathrm{~d}, \mathrm{~J}=6.5 \mathrm{~Hz}, 2 \mathrm{H}), 2.30(\mathrm{p}, \mathrm{J}=6.9 \mathrm{~Hz}, 2 \mathrm{H}), 13 \mathrm{C}$ NMR (101 MHz, DMSO-d6) $\delta$ $145.0,133.4,130.2,126.9,124.1,122.0,121.6,47.7,40.1,28.3 . \mathrm{m} / \mathrm{z} 447.11 \mathrm{M}+\mathrm{H}$ (calculated 447.85). 


\section{PL404 ((1-(3-((7-chloroquinolin-4-yl)amino)propyl)-1H-1,2,3-triazol-4- yl)diphenylmethanol)}

To a stirred solution of PL409 (1 eq, $0.50 \mathrm{~g}, 1.9 \mathrm{mmol})$, 1,1-diphenyl-2-propyn-1-ol (1.07 eq, $0.42 \mathrm{~g}, 2.84 \mathrm{mmol})$ in tert-butanol $(23 \mathrm{ml})$, a solution of $\mathrm{CuSO}_{4} .5 \mathrm{H}_{2} \mathrm{O}(0.2 \mathrm{eq}, 0.095$ $\mathrm{g}, 0.38 \mathrm{mmol})$ and sodium ascorbate $(0.4 \mathrm{eq}, 0.15 \mathrm{~g}, 0.76 \mathrm{mmol})$ in water $(23 \mathrm{ml})$ was added, and the mixture was stirred for 3 hours at $40{ }^{\circ} \mathrm{C}$. After completion, the reaction mixture was cooled to $\mathrm{RT}$ and taken by $\mathrm{CHCl}_{3}(60 \mathrm{ml})$ and washed with water $(3 * 300$ $\mathrm{ml})$. Finally the organic layer was dried by anhydrous $\mathrm{MgSO}_{4}$, filtered and concentrated The crude was purified using combi-flash chromatography in silica column by eluting using $\mathrm{CHCl}_{3}: \mathrm{MeOH}(90: 10)$ to give a pure white-yellowish solid $(0.35 \mathrm{~g}, 41 \%) .{ }^{1} \mathrm{H}$ NMR (400 MHz, DMSO-d6) $\delta 8.37$ (d, J = 5.4 Hz, 1H), 8.26 (d, J = 9.0 Hz, 1H), 7.88 (s, 1H), $7.79(\mathrm{~d}, \mathrm{~J}=2.3 \mathrm{~Hz}, 1 \mathrm{H}), 7.46(\mathrm{dd}, \mathrm{J}=9.0,2.3 \mathrm{~Hz}, 1 \mathrm{H}), 7.40-7.17(\mathrm{~m}, 10 \mathrm{H}), 6.54$ $(\mathrm{s}, 1 \mathrm{H}), 6.40(\mathrm{~d}, \mathrm{~J}=5.4 \mathrm{~Hz}, 1 \mathrm{H}), 4.51(\mathrm{t}, \mathrm{J}=6.9 \mathrm{~Hz}, 2 \mathrm{H}), 3.33-3.24(\mathrm{~m}, 2 \mathrm{H}), 2.22(\mathrm{p}, \mathrm{J}$ $=7.0 \mathrm{~Hz}, 2 \mathrm{H}) .{ }^{13} \mathrm{C}$ NMR $(101 \mathrm{MHz}, \mathrm{DMSO}-\mathrm{d} 6) \delta 153.9,151.9,149.9,149.0,147.1$, $133.4,127.5(\mathrm{~d}, \mathrm{~J}=3.6 \mathrm{~Hz}), 127.0$, $126.6,124.1(\mathrm{~d}, \mathrm{~J}=3.8 \mathrm{~Hz}), 123.4,117.5$, 98.6 , $75.7,59.7,47.2,38.9,28.5,14.1 . \mathrm{m} / \mathrm{z} 469.17 \mathrm{M}+\mathrm{H}$ (calculated 469.97).

\section{PL405 (7-chloro-N-(3-(4-(2-methoxyphenyl)-1H-1,2,3-triazol-1-yl)propyl)quinolin-4- amine)}

To a stirred solution of PL409 (1 eq, $0.50 \mathrm{~g}, 1.9 \mathrm{mmol})$, 2-ethynylanisole (1.07 eq, 0.26 $\mathrm{ml}, 2.04 \mathrm{mmol})$ in tert-butanol $(19 \mathrm{ml})$, was added $\mathrm{CuSO}_{4} .5 \mathrm{H}_{2} \mathrm{O}(0.2 \mathrm{eq}, 0.095 \mathrm{~g}, 0.38$ $\mathrm{mmol})$ and sodium ascorbate $(0.4 \mathrm{eq}, 0.15 \mathrm{~g}, 0.76 \mathrm{mmol})$ in water $(19 \mathrm{ml})$, and the mixture was stirred for 3 hours at $40{ }^{\circ} \mathrm{C}$. After completion, the crude mixture was taken 
by $\mathrm{CHCl}_{3}(25 \mathrm{ml})$ and washed with water $(3 * 120 \mathrm{ml})$. Finally the organic layer was dried by anhydrous $\mathrm{MgSO}_{4}$, filtered and concentrated. The crude was purified using combi-flash chromatography in silica column by eluting using $\mathrm{CHCl}_{3}: \mathrm{MeOH}(90: 10)$ to give a pure solid $(0.54 \mathrm{~g}, 72 \%) .{ }^{1} \mathrm{H}$ NMR $(400 \mathrm{MHz}$, DMSO-d6) $\delta 8.42(\mathrm{~s}, 1 \mathrm{H}), 8.34-$ $8.26(\mathrm{~m}, 1 \mathrm{H}), 8.13(\mathrm{dd}, \mathrm{J}=7.7,1.8 \mathrm{~Hz}, 1 \mathrm{H}), 7.81(\mathrm{~s}, 1 \mathrm{H}), 7.45(\mathrm{dd}, \mathrm{J}=13.8,7.3 \mathrm{~Hz}, 2 \mathrm{H})$, $7.33(\mathrm{td}, \mathrm{J}=8.0,1.8 \mathrm{~Hz}, 1 \mathrm{H}), 7.16-6.99(\mathrm{~m}, 3 \mathrm{H}), 6.51(\mathrm{~s}, 1 \mathrm{H}), 4.58(\mathrm{t}, \mathrm{J}=6.9 \mathrm{~Hz}, 2 \mathrm{H})$, 3.89 (s, 3H), 3.34 (q, J = 6.4 Hz, 2H), 2.29 (p, J = 6.7 Hz, 2H). ${ }^{13} \mathrm{C}$ NMR (101 MHz, DMSO-d6) $\delta 155.3,141.7,133.5,128.8,126.5,124.2,124.0,120.6,119.1,111.5$, $55.4,47.4,40.1,28.5 . \mathrm{m} / \mathrm{z} 393.14 \mathrm{M}+\mathrm{H}$ (calculated 393.88).

\section{PL406 (7-chloro-N-(3-(4-(3-methoxyphenyl)-1H-1,2,3-triazol-1-yl)propyl)quinolin-4- amine)}

To a stirred solution of PL409 (1 eq, $0.50 \mathrm{~g}, 1.9 \mathrm{mmol}$ ), 3-ethynylanisole (1.07 eq, 0.26 $\mathrm{ml}, 2.04 \mathrm{mmol})$ in tert-butanol $(19 \mathrm{ml})$, was added $\mathrm{CuSO}_{4} .5 \mathrm{H}_{2} \mathrm{O}(0.2 \mathrm{eq}, 0.095 \mathrm{~g}, 0.38$ $\mathrm{mmol})$ and sodium ascorbate $(0.4 \mathrm{eq}, 0.15 \mathrm{~g}, 0.76 \mathrm{mmol})$ in water $(19 \mathrm{ml})$ was added and the mixture was stirred for 3 hours at $40{ }^{\circ} \mathrm{C}$. After completion, the crude mixture was taken by $\mathrm{CHCl}_{3}(25 \mathrm{ml})$ and washed with water $(3 * 120 \mathrm{ml})$. Finally the organic layer was dried by anhydrous $\mathrm{MgSO}_{4}$, filtered and concentrated. The crude was purified using combi-flash chromatography in silica column by eluting using $\mathrm{CHCl}_{3}: \mathrm{MeOH}(90: 10)$ to give a pure white-yellowish solid (0.38 g, $51 \%) .{ }^{1} \mathrm{H}$ NMR (400 MHz, DMSO-d6) $\delta 8.64$ (s, 1H), $8.29(\mathrm{~d}, \mathrm{~J}=8.9 \mathrm{~Hz}, 1 \mathrm{H}), 7.81(\mathrm{~s}, 1 \mathrm{H}), 7.54-7.31(\mathrm{~m}, 5 \mathrm{H}), 6.90(\mathrm{ddd}, \mathrm{J}=8.1$, 2.6, $1.2 \mathrm{~Hz}, 1 \mathrm{H}), 6.53(\mathrm{~s}, 1 \mathrm{H}), 4.56(\mathrm{t}, \mathrm{J}=6.9 \mathrm{~Hz}, 2 \mathrm{H}), 3.81(\mathrm{~s}, 3 \mathrm{H}), 3.36(\mathrm{q}, \mathrm{J}=6.5 \mathrm{~Hz}$, 2H), $2.30(\mathrm{p}, \mathrm{J}=7.0 \mathrm{~Hz}, 2 \mathrm{H}) .{ }^{13} \mathrm{C}$ NMR $(101 \mathrm{MHz}$, DMSO-d6) $\delta 159.6,150.2,146.2$, 
$133.7,132.1,130.0,124.2,121.7,117.4,113.5,110.3,55.1,47.6,38.9,28.3 . \mathrm{m} / \mathrm{z}$ 393.14 M + H (calculated 393.88).

\section{PL407 (7-chloro-N-(3-(4-(2-fluorophenyl)-1H-1,2,3-triazol-1-yl)propyl)quinolin-4- amine)}

To a stirred solution of PL409 (1 eq, $0.50 \mathrm{~g}, 1.9 \mathrm{mmol}$ ), 2-fluorophenylacetlene (1.07 eq, $0.24 \mathrm{ml}, 2.04 \mathrm{mmol})$ in tert-butanol $(15 \mathrm{ml})$, was added $\mathrm{CuSO}_{4} .5 \mathrm{H}_{2} \mathrm{O}(0.2 \mathrm{eq}, 0.095 \mathrm{~g}$, $0.38 \mathrm{mmol})$ and sodium ascorbate $(0.4 \mathrm{eq}, 0.15 \mathrm{~g}, 0.76 \mathrm{mmol})$ in water $(15 \mathrm{ml})$ was added and the mixture was stirred for 3 hours at $40{ }^{\circ} \mathrm{C}$. After completion, the mixture of solvents was evaporated and the solid was purified using combi-flash chromatography in silica column by eluting using $\mathrm{CHCl}_{3}: \mathrm{MeOH}(90: 10)$ to give a pure white-yellowish solid $(0.10 \mathrm{~g}, 26 \%) .{ }^{1} \mathrm{H}$ NMR (400 MHz, DMSO-d6) $\delta 8.50(\mathrm{~d}, \mathrm{~J}=3.7 \mathrm{~Hz}, 1 \mathrm{H}), 8.41(\mathrm{~d}, \mathrm{~J}=$ $5.3 \mathrm{~Hz}, 1 \mathrm{H}), 8.26(\mathrm{dd}, \mathrm{J}=9.0,5.6 \mathrm{~Hz}, 1 \mathrm{H}), 8.13(\mathrm{td}, \mathrm{J}=7.6,1.7 \mathrm{~Hz}, 1 \mathrm{H}), 7.79(\mathrm{~d}, \mathrm{~J}=2.4$ Hz, 1H), $7.45(\mathrm{dd}, 1 \mathrm{H}), 7.40(\mathrm{dt}, 1 \mathrm{H}), 7.34(\mathrm{t}, 3 \mathrm{H}), 6.48(\mathrm{dd}, \mathrm{J}=11.0,5.4 \mathrm{~Hz}, 1 \mathrm{H}), 4.62(\mathrm{t}$, $\mathrm{J}=6.7 \mathrm{~Hz}, 2 \mathrm{H}), 3.32(\mathrm{~s}, 2 \mathrm{H}), 2.30(\mathrm{p}, \mathrm{J}=6.8 \mathrm{~Hz}, 2 \mathrm{H}) \cdot{ }^{13} \mathrm{C}$ NMR $(101 \mathrm{MHz}$, DMSO-d6) $\delta$ $151.9,149.9,149.0,133.4,127.4,124.9,124.1,117.5,98.7,48.5,47.6,40.1,28.4$, 27.1. $\mathrm{m} / \mathrm{z} 381.12 \mathrm{M}+\mathrm{H}$ (calculated 381.84).

\section{PL408 (7-chloro-N-(3-(4-(3,4-difluorophenyl)-1H-1,2,3-triazol-1-yl)propyl)quinolin- 4-amine)}

To a stirred solution of PL409 (1 eq, $0.50 \mathrm{~g}, 1.9 \mathrm{mmol}$ ), 3,4-difluorophenylacetlene (1.07 eq, $0.25 \mathrm{ml}, 2.04 \mathrm{mmol})$ in tert-butanol $(15 \mathrm{ml}), \mathrm{CuSO}_{4} .5 \mathrm{H}_{2} \mathrm{O}(0.2 \mathrm{eq}, 0.095 \mathrm{~g}, 0.38$ mmol) and sodium ascorbate $(0.4 \mathrm{eq}, 0.15 \mathrm{~g}, 0.76 \mathrm{mmol})$ in water $(15 \mathrm{ml})$ was added and the mixture was stirred for 3 hours at $40{ }^{\circ} \mathrm{C}$. After completion, the mixture of solvents 
was evaporated and the solid was purified using combi-flash chromatography in silica column by eluting using $\mathrm{CHCl}_{3}: \mathrm{MeOH}(90: 10)$ to give a pure white-yellowish solid $(0.58$ g, $76 \%$ ). ${ }^{1} \mathrm{H}$ NMR (400 MHz, DMSO-d6) $\delta 8.66$ (s, 1H), 8.40 (d, 1H), 8.24 (d, 1H), 7.84 $(\mathrm{dt}, 1 \mathrm{H}), 7,78(\mathrm{~d}, 1 \mathrm{H}), 7.67(\mathrm{dtd}, \mathrm{J}=10.6,4.6,3.6,1.9 \mathrm{~Hz}, 1 \mathrm{H}), 7.60-7.29(\mathrm{~m}, 3 \mathrm{H}), 6.49$ $(\mathrm{d}, 1 \mathrm{H}), 4.56(\mathrm{t}, 2 \mathrm{H}), 3.36(\mathrm{dd}, \mathrm{J}=14.3,7.7 \mathrm{~Hz}, 2 \mathrm{H}), 2.29(\mathrm{p}, \mathrm{J}=7.2 \mathrm{~Hz}, 2 \mathrm{H}) .{ }^{13} \mathrm{C} \mathrm{NMR}$ (101 MHz, DMSO-d6) $\delta 151.9,149.9,148.9,133.4,127.5$, 124.1, 122.1 , 118.2 , 98.8 , 47.7 , 40.1 , 28.2. m/z 399.11 M + H (calculated 399.83).

\section{PL409 (N-(3-azidopropyl)-7-chloroquinolin-4-amine)}

PL29 (1 eq, 7.0 g, $22.2 \mathrm{mmol}$ ) was dissolved in anhydrous dimethylformamide (100ml). Sodium azide ( $2 \mathrm{eq}, 2.9 \mathrm{~g}, 44.5 \mathrm{mmol}$ ) was added and the mixture was stirred at $55^{\circ} \mathrm{C}$ for 12 hours. After completion, De-ionized water $(135 \mathrm{ml})$ was added and the aqueous layer was extracted with toluene $(3 * 330 \mathrm{ml})$. The organic layer was dried with brine $(130 \mathrm{ml})$, dried by anhydrous $\mathrm{MgSO}_{4}$, filtered and evaporated to give yellow solid (5.1 g, $\left.88 \%\right) .{ }^{1} \mathrm{H}$ NMR (400 MHz, Chloroform-d) $\delta 8.55(\mathrm{~d}, \mathrm{~J}=5.3 \mathrm{~Hz}, 1 \mathrm{H}), 7.96(\mathrm{~d}, \mathrm{~J}=2.1 \mathrm{~Hz}, 1 \mathrm{H}), 7.67$ $(\mathrm{d}, \mathrm{J}=8.9 \mathrm{~Hz}, 1 \mathrm{H}), 7.36(\mathrm{dd}, \mathrm{J}=9.0,2.2 \mathrm{~Hz}, 1 \mathrm{H}), 6.42(\mathrm{~d}, \mathrm{~J}=5.3 \mathrm{~Hz}, 1 \mathrm{H}), 5.35(\mathrm{t}, \mathrm{J}=$ $5.4 \mathrm{~Hz}, 1 \mathrm{H}), 3.57-3.40(\mathrm{~m}, 4 \mathrm{H}), 2.02(\mathrm{p}, \mathrm{J}=6.6 \mathrm{~Hz}, 2 \mathrm{H})$.

\section{PL410 (N¹'-(7-chloroquinolin-4-yl)-N3-methyl-N3-(3-phenyl-3-(4- (trifluoromethyl)phenoxy)propyl)propane-1,3-diamine)}

First, the free base fluoxetine was prepared by dissolving fluoxetine $\mathrm{HCl}(1 \mathrm{eq}, 0.55 \mathrm{~g}$, $1.59 \mathrm{mmol})$ in water $(7 \mathrm{ml})$. Solid $\mathrm{NaHCO}_{3}(2.28 \mathrm{eq}, 0.30 \mathrm{~g}, 3.62 \mathrm{mmol})$ was added and the mixture was extracted with dichloromethane $(9 \mathrm{ml} * 3)$. The organic phase was dried with anhydrous $\mathrm{MgSO}_{4}$, filtered and evaporated to give yellow oliy liquid $(0.51 \mathrm{~g}, 93 \%)$. 
The free-base fluoxetine ( $1 \mathrm{eq}, 0.51 \mathrm{~g}, 1.65 \mathrm{mmol})$ was dissolved in tetrahydrofuran (18ml), followed by addition of PL29 (1.33 eq, $0.69 \mathrm{~g}, 2.19 \mathrm{mmol})$ and triethylamine (2.9 eq, $0.67 \mathrm{ml}, 4.79 \mathrm{mmol}$ ) and the reaction mixture was stirred for 72 hours at $55^{\circ} \mathrm{C}$. After the reaction completion was confirmed by TLC on alumina plate, the reaction was cooled to RT and THF was evaporated by rotovap. The crude was washed with EtOAC (25ml) and saturated $\mathrm{NaHCO}_{3}(25 \mathrm{ml})$. The organic layer was separated and the aqueous layer was washed with EtOAC $(2 * 15 \mathrm{ml})$. The organic layer was finally dried by anhydrous $\mathrm{MgSO}_{4}$, filtered and evaporated. The crude was purified by combi-flash chromatography on alumina column using EtOAC:Hexane as eluents to get a yellow solid $(0.6 \mathrm{~g}, 69 \%) .{ }^{1} \mathrm{H}$ NMR (400 MHz, DMSO-d6) $\delta 8.37$ (d, J = 5.4 Hz, 1H), 8.21 (d, J = 9.0 Hz, 1H), 7.78 (d, $\mathrm{J}=2.2 \mathrm{~Hz}, 1 \mathrm{H}), 7.56-7.38(\mathrm{~m}, 3 \mathrm{H}), 7.37-7.19(\mathrm{~m}, 6 \mathrm{H}), 6.98(\mathrm{~d}, \mathrm{~J}=8.6 \mathrm{~Hz}, 2 \mathrm{H}), 6.40$ $(\mathrm{d}, \mathrm{J}=5.5 \mathrm{~Hz}, 1 \mathrm{H}), 5.44(\mathrm{dd}, \mathrm{J}=8.2,4.8 \mathrm{~Hz}, 1 \mathrm{H}), 3.49-3.37(\mathrm{~m}, 2 \mathrm{H}), 3.23(\mathrm{dtd}, \mathrm{J}=$ 19.6, 12.8, 6.4 Hz, 2H), $2.57-2.26(\mathrm{~m}, 2 \mathrm{H}), 2.19(\mathrm{~s}, 3 \mathrm{H}), 2.16-1.86(\mathrm{~m}, 2 \mathrm{H}), 1.86-$ $1.70(\mathrm{~m}, 2 \mathrm{H}) .{ }^{13} \mathrm{C}$ NMR (101 MHz, DMSO-d6) $\delta 160.5,151.9,150.1,149.0,141.0$, 133.3, 128.5, 127.6, 126.9 - $126.6(\mathrm{~m}), 125.9,124.0(\mathrm{~d}, \mathrm{~J}=4.8 \mathrm{~Hz}), 120.8,117.4$, $116.0,98.6,77.4,54.8,53.2,41.9,40.7,35.7,25.3,22.3 . \mathrm{m} / \mathrm{z} 527.20 \mathrm{M}+\mathrm{H}$ (calculated 528.02).

\section{PL411 (7-chloro-N-(3-(4-phenyl-1H-1,2,3-triazol-1-yl)propyl)quinolin-4-amine)}

To a stirred solution of PL409 (1 eq, $0.50 \mathrm{~g}, 1.9 \mathrm{mmol})$, Ethynyl-benzene (1eq, $0.21 \mathrm{ml}$, $1.9 \mathrm{mmol})$ in tert-butanol $(5 \mathrm{ml}), \mathrm{CuSO}_{4} .5 \mathrm{H}_{2} \mathrm{O}(0.2 \mathrm{eq}, 0.095 \mathrm{~g}, 0.38 \mathrm{mmol})$ and sodium ascorbate $(0.4 \mathrm{eq}, 0.15 \mathrm{~g}, 0.76 \mathrm{mmol})$ in water $(5 \mathrm{ml})$ was added and the mixture was stirred for 4 hours at $40{ }^{\circ} \mathrm{C}$. After completion, the mixture of solvents was evaporated and 
the solid was purified using combi-flash chromatography in silica column by eluting using $\mathrm{CHCl}_{3}: \mathrm{MeOH}(90: 10)$ to give a pure white-yellowish solid $(0.34 \mathrm{~g}, 50 \%) .{ }^{1} \mathrm{H} \mathrm{NMR}$ (400 MHz, DMSO-d6) $\delta 8.62(\mathrm{~s}, 1 \mathrm{H}), 8.40(\mathrm{~d}, \mathrm{~J}=5.4 \mathrm{~Hz}, 1 \mathrm{H}), 8.27(\mathrm{~d}, 1 \mathrm{H}), 7.94-7.74$ $(\mathrm{m}, 3 \mathrm{H}), 7.50-7.28(\mathrm{~m}, 5 \mathrm{H}), 6.48(\mathrm{dd}, \mathrm{J}=5.5,3.7 \mathrm{~Hz}, 1 \mathrm{H}), 4.59(\mathrm{dt}, \mathrm{J}=11.1,6.9 \mathrm{~Hz}$,

2H), $3.34(\mathrm{dt}, \mathrm{J}=13.4,6.9 \mathrm{~Hz}, 2 \mathrm{H}), 2.30(\mathrm{q}, 2 \mathrm{H}) .{ }^{13} \mathrm{C}$ NMR (101 MHz, DMSO-d6) $\delta$ $151.9,149.9(\mathrm{~d}, \mathrm{~J}=5.9 \mathrm{~Hz}), 149.5,148.9,146.3,137.1,133.4,130.8,128.9,127.8$, 127.5, 125.1, $124.1(\mathrm{~d}, \mathrm{~J}=3.6 \mathrm{~Hz}), 122.9,121.5,119.3,117.5,98.7,47.6,40.1,28.34$. $\mathrm{m} / \mathrm{z} 363.13 \mathrm{M}+\mathrm{H}$ (calculated 363.85).

\section{PL412 (7-chloro-N-(3-(4-(pyridin-2-yl)-1H-1,2,3-triazol-1-yl)propyl)quinolin-4- amine)}

To a stirred solution of PL409 (1 eq, $0.25 \mathrm{~g}, 1.9 \mathrm{mmol}$ ), 2-Ethynylpyridine (1eq, 0.1ml, $1.9 \mathrm{mmol})$ in tert-butanol $(5 \mathrm{ml}), \mathrm{CuSO}_{4} .5 \mathrm{H}_{2} \mathrm{O}(0.2 \mathrm{eq}, 0.095 \mathrm{~g}, 0.38 \mathrm{mmol})$ and sodium ascorbate $(0.4 \mathrm{eq}, 0.15 \mathrm{~g}, 0.76 \mathrm{mmol})$ in water $(5 \mathrm{ml})$ was added and the mixture was stirred for 4 hours at $40{ }^{\circ} \mathrm{C}$. After completion, the mixture of solvents was evaporated and the solid was purified using combi-flash chromatography in silica column by eluting using $\mathrm{CHCl}_{3}: \mathrm{MeOH}(90: 10)$ to give a yellow solid $(0.16 \mathrm{~g}, 46 \%) .{ }^{1} \mathrm{H}$ NMR $(400 \mathrm{MHz}$, DMSO-d6) $\delta 8.48(\mathrm{~s}, 2 \mathrm{H}), 7.45(\mathrm{~s}, 1 \mathrm{H}), 7.37(\mathrm{~s}, 1 \mathrm{H}), 6.76(\mathrm{~s}, 1 \mathrm{H}), 4.70(\mathrm{~s}, 2 \mathrm{H}), 3.17(\mathrm{~d}, \mathrm{~J}$ $=5.0 \mathrm{~Hz}, 2 \mathrm{H}), 2.09(\mathrm{~s}, 2 \mathrm{H})$.

\section{PL413 (7-chloro-N-(3-(4-(p-tolyl)-1H-1,2,3-triazol-1-yl)propyl)quinolin-4-amine)}

To a stirred solution of PL409 (1 eq, $0.50 \mathrm{~g}, 1.9 \mathrm{mmol}$ ), 4-Ethynyltoluene (1 eq, $0.24 \mathrm{ml}$, $1.9 \mathrm{mmol})$ in tert-butanol $(5 \mathrm{ml}), \mathrm{CuSO}_{4} .5 \mathrm{H}_{2} \mathrm{O}(0.2 \mathrm{eq}, 0.095 \mathrm{~g}, 0.38 \mathrm{mmol})$ and sodium ascorbate $(0.4 \mathrm{eq}, 0.15 \mathrm{~g}, 0.76 \mathrm{mmol})$ in water $(5 \mathrm{ml})$ was added and the mixture was 
stirred for 4 hours at $40{ }^{\circ} \mathrm{C}$. After completion, the mixture of solvents was evaporated and the solid was recrystallized by $\mathrm{CHCl}_{3}: \mathrm{MeOH}(90: 10)$ to give a pure solid $(0.4 \mathrm{~g}, 56 \%) .{ }^{1} \mathrm{H}$ NMR (400 MHz, DMSO-d6) $\delta 8.55$ (s, 1H), $8.41(\mathrm{~s}, 1 \mathrm{H}), 8.29(\mathrm{~d}, 1 \mathrm{H}), 7.81(\mathrm{~d}, 1 \mathrm{H}), 7.71$ (d, 2H), $7.46(\mathrm{~d}, 1 \mathrm{H}), 7.43(\mathrm{t}, 1 \mathrm{H}), 7.25(\mathrm{~d}, 2 \mathrm{H}), 6.52(\mathrm{~d}, 1 \mathrm{H}), 4.55(\mathrm{t}, 2 \mathrm{H}), 3.43(\mathrm{~d}, 2 \mathrm{H})$, 2.32 (s, 3H), 2.27 (q, 2H). ${ }^{13} \mathrm{C}$ NMR (101 MHz, DMSO-d6) $\delta$ 137.1, 129.4, 128.0, 125.0, 121.1, 47.5, 28.1, 20.8. m/z 377.14 M + H (calculated 377.88).

\section{PL414 (N-(3-(4-benzyl-1H-1,2,3-triazol-1-yl)propyl)-7-chloroquinolin-4-amine)}

To a stirred solution of PL409 (1 eq, $0.50 \mathrm{~g}, 1.9 \mathrm{mmol}$ ), 3-phenyl-1-propyne (1 eq, 0.24 $\mathrm{ml}, 1.9 \mathrm{mmol})$ in tert-butanol $(5 \mathrm{ml}), \mathrm{CuSO}_{4} .5 \mathrm{H}_{2} \mathrm{O}(0.2 \mathrm{eq}, 0.095 \mathrm{~g}, 0.38 \mathrm{mmol})$ and sodium ascorbate $(0.4 \mathrm{eq}, 0.15 \mathrm{~g}, 0.76 \mathrm{mmol})$ in water $(5 \mathrm{ml})$ was added and the mixture was stirred for 4 hours at $40{ }^{\circ} \mathrm{C}$. After completion, the mixture of solvents was evaporated and the solid was recrystallized by $\mathrm{CHCl}_{3}: \mathrm{MeOH}$ (90:10) to give a pure solid (0.33 $\mathrm{g}$, 45\%). ${ }^{1} \mathrm{H}$ NMR (400 MHz, DMSO-d6) $\delta 8.31(\mathrm{~d}, \mathrm{~J}=6.1 \mathrm{~Hz}, 1 \mathrm{H}), 7.88(\mathrm{~s}, 1 \mathrm{H}), 7.82(\mathrm{~d}$, 1H), $7.46(\mathrm{dd}, \mathrm{J}=10.5,7.1 \mathrm{~Hz}, 2 \mathrm{H}), 7.35-7.15(\mathrm{~m}, 6 \mathrm{H}), 6.48(\mathrm{~s}, 1 \mathrm{H}), 4.46(\mathrm{t}, \mathrm{J}=6.9 \mathrm{~Hz}$,

2H), 3.98 (s, 2H), 3.28 (q, J = 6.5 Hz, 2H), 2.20 (p, J = 6.9 Hz, 2H). ${ }^{13} \mathrm{C}$ NMR (101 MHz, DMSO-d6) $\delta 150.1,146.1,139.6,133.6,128.4(\mathrm{~d}, \mathrm{~J}=8.9 \mathrm{~Hz}), 126.1,124.3,122.6,47.2$, 38.9, 31.3, 28.4. $\mathrm{m} / \mathrm{z} 377.14 \mathrm{M}+\mathrm{H}$ (calculated 377.88).

\section{PL415 (N-(3-(4-(4-aminophenyl)-1H-1,2,3-triazol-1-yl)propyl)-7-chloroquinolin-4- amine)}

To a stirred solution of PL409 (1 eq, $0.50 \mathrm{~g}, 1.9 \mathrm{mmol})$, 4-ethynylaniline (1 eq, $0.22 \mathrm{~g}$, $1.9 \mathrm{mmol})$ in tert-butanol $(5 \mathrm{ml}), \mathrm{CuSO}_{4} .5 \mathrm{H}_{2} \mathrm{O}(0.2 \mathrm{eq}, 0.095 \mathrm{~g}, 0.38 \mathrm{mmol})$ and sodium ascorbate $(0.4 \mathrm{eq}, 0.15 \mathrm{~g}, 0.76 \mathrm{mmol})$ in water $(5 \mathrm{ml})$ was added and the mixture was 
stirred for 4 hours at $40{ }^{\circ} \mathrm{C}$. After completion, the mixture of solvents was evaporated and the solid was recrystallized by $\mathrm{CHCl}_{3}: \mathrm{MeOH}(90: 10)$ to give a pure solid $(0.52 \mathrm{~g}, 72 \%)$. ${ }^{1} \mathrm{H}$ NMR (400 MHz, DMSO-d6) $\delta 8.40(\mathrm{~s}, 1 \mathrm{H}), 8.28(\mathrm{~d}, \mathrm{~J}=20.1 \mathrm{~Hz}, 2 \mathrm{H}), 7.80(\mathrm{~d}, \mathrm{~J}=2.4$ $\mathrm{Hz}, 1 \mathrm{H}), 7.53-7.35(\mathrm{~m}, 4 \mathrm{H}), 6.62(\mathrm{~m}, 2 \mathrm{H}), 6.48(\mathrm{~d}, \mathrm{~J}=5.4 \mathrm{~Hz}, 1 \mathrm{H}), 5.22(\mathrm{~s}, 2 \mathrm{H}), 4.51(\mathrm{t}$, $\mathrm{J}=6.9 \mathrm{~Hz}, 2 \mathrm{H}), 3.35(\mathrm{~m}, 2 \mathrm{H}), 2.25(\mathrm{dq}, \mathrm{J}=11.5,5.8,4.6 \mathrm{~Hz}, 2 \mathrm{H}) .{ }^{13} \mathrm{C} \mathrm{NMR}(101 \mathrm{MHz}$, DMSO-d6) $\delta 151.8,150.0,148.5,147.3,133.5,127.3,126.1,124.1(\mathrm{~d}, \mathrm{~J}=8.6 \mathrm{~Hz})$ 119.3, 118.4, 113.9, 98.8, 47.3, 38.8, 28.4. m/z 378.14 M + H (calculated 378.86).

\section{PL416 (N-(3-(4-(4-bromophenyl)-1H-1,2,3-triazol-1-yl)propyl)-7-chloroquinolin-4- amine)}

To a stirred solution of PL409 (1 eq, $0.25 \mathrm{~g}, 0.95 \mathrm{mmol}$ ), 1-Bromo-4-Ethynylbenzene (1 eq, $0.17 \mathrm{~g}, 0.95 \mathrm{mmol})$ in tert-butanol $(4 \mathrm{ml}), \mathrm{CuSO}_{4} .5 \mathrm{H}_{2} \mathrm{O}(0.2 \mathrm{eq}, 0.047 \mathrm{~g}, 0.19 \mathrm{mmol})$ and sodium ascorbate $(0.4 \mathrm{eq}, 0.075 \mathrm{~g}, 0.38 \mathrm{mmol})$ in water $(4 \mathrm{ml})$ was added and the mixture was stirred for 4 hours at $40{ }^{\circ} \mathrm{C}$. After completion, the mixture of solvents was evaporated and the solid was recrystallized by $\mathrm{CHCl}_{3}: \mathrm{MeOH}$ (90:10) to give a pure solid $(0.29 \mathrm{~g}, 69 \%) .{ }^{1} \mathrm{H}$ NMR $(400 \mathrm{MHz}$, DMSO-d6) $\delta 8.65(\mathrm{~s}, 1 \mathrm{H}), 8.58(\mathrm{~s}, 1 \mathrm{H}), 7.78(\mathrm{~d}, \mathrm{~J}=$ $8.1 \mathrm{~Hz}, 2 \mathrm{H}), 7.68-7.55(\mathrm{~m}, 3 \mathrm{H}), 7.45(\mathrm{~d}, \mathrm{~J}=8.6 \mathrm{~Hz}, 1 \mathrm{H}), 4.56(\mathrm{t}, \mathrm{J}=6.8 \mathrm{~Hz}, 2 \mathrm{H}), 3.34$ $(\mathrm{d}, \mathrm{J}=5.9 \mathrm{~Hz}, 2 \mathrm{H}), 2.35-2.19(\mathrm{~m}, 2 \mathrm{H}) .{ }^{13} \mathrm{C}$ NMR (101 MHz, DMSO-d6) $\delta 145.3,131.8$, $129.9,127.1,124.6,121.9,120.8,47.6,40.1,38.8,28.1 . \mathrm{m} / \mathrm{z} 443.04 \mathrm{M}+\mathrm{H}$ (calculated 442.75). 
PL417 (7-chloro-N-(3-(4-(4-methoxyphenyl)-1H-1,2,3-triazol-1-yl)propyl)quinolin-4amine)

To a stirred solution of PL409 (1 eq, $0.25 \mathrm{~g}, 0.95 \mathrm{mmol})$, 4-Ethynylanisole (1 eq, 0.13 $\mathrm{ml}, 0.95 \mathrm{mmol})$ in tert-butanol $(4 \mathrm{ml}), \mathrm{CuSO}_{4} .5 \mathrm{H}_{2} \mathrm{O}(0.2 \mathrm{eq}, 0.047 \mathrm{~g}, 0.19 \mathrm{mmol})$ and sodium ascorbate $(0.4 \mathrm{eq}, 0.075 \mathrm{~g}, 0.38 \mathrm{mmol})$ in water $(4 \mathrm{ml})$ was added and the mixture was stirred for 4 hours at $40{ }^{\circ} \mathrm{C}$. After completion, the mixture of solvents was evaporated and the solid was recrystallized by $\mathrm{CHCl}_{3}: \mathrm{MeOH}(90: 10)$ to give a pure solid $(0.19 \mathrm{~g}$, $51 \%) .{ }^{1} \mathrm{H}$ NMR (400 MHz, DMSO-d6) $\delta 8.49$ (s, 1H), 8.33 (s, 1H), 7.84 (s, 1H), 7.79 $7.70(\mathrm{~m}, 2 \mathrm{H}), 7.54-7.43(\mathrm{~m}, 2 \mathrm{H}), 7.05-6.97(\mathrm{~m}, 2 \mathrm{H}), 6.57(\mathrm{~s}, 1 \mathrm{H}), 4.54(\mathrm{t}, \mathrm{J}=6.9 \mathrm{~Hz}$, 2H), $3.79(\mathrm{~d}, \mathrm{~J}=1.2 \mathrm{~Hz}, 3 \mathrm{H}), 3.34(\mathrm{~d}, \mathrm{~J}=6.4 \mathrm{~Hz}, 2 \mathrm{H}), 2.27(\mathrm{tt}, \mathrm{J}=12.9,5.7 \mathrm{~Hz}, 2 \mathrm{H}) .{ }^{13} \mathrm{C}$ NMR (101 MHz, DMSO-d6) $\delta 158.9,146.2,126.4,124.3,120.5,114.3,55.1,47.5,38.8$, 28.3. $\mathrm{m} / \mathrm{z} 393.14 \mathrm{M}+\mathrm{H}$ (calculated 393.88).

\section{PL418 (7-chloro-N-(3-(4-(4-chlorophenyl)-1H-1,2,3-triazol-1-yl)propyl)quinolin-4- amine)}

To a stirred solution of PL409 (1 eq, $0.25 \mathrm{~g}, 0.95 \mathrm{mmol}$ ), 1-Chloro-4-Ethynylbenzene (1 eq, $0.13 \mathrm{~g}, 0.95 \mathrm{mmol})$ in tert-butanol (4 ml), $\mathrm{CuSO}_{4} .5 \mathrm{H}_{2} \mathrm{O}(0.2 \mathrm{eq}, 0.047 \mathrm{~g}, 0.19 \mathrm{mmol})$ and sodium ascorbate $(0.4 \mathrm{eq}, 0.075 \mathrm{~g}, 0.38 \mathrm{mmol})$ in water $(4 \mathrm{ml})$ was added and the mixture was stirred for 4 hours at $40{ }^{\circ} \mathrm{C}$. After completion, the mixture of solvents was evaporated and the solid was recrystallized by $\mathrm{CHCl}_{3}: \mathrm{MeOH}(90: 10)$ to give a pure solid (0.28 g, 76 \%). ${ }^{1} \mathrm{H}$ NMR (400 MHz, DMSO-d6) $\delta 8.64(\mathrm{~s}, 1 \mathrm{H}), 7.84$ (d, J = 8.3 Hz, 2H), $7.48(\mathrm{dd}, \mathrm{J}=26.9,8.3 \mathrm{~Hz}, 4 \mathrm{H}), 6.91(\mathrm{~s}, 1 \mathrm{H}), 4.57(\mathrm{t}, \mathrm{J}=6.7 \mathrm{~Hz}, 2 \mathrm{H}), 3.34(\mathrm{p}, \mathrm{J}=5.4,4.4$ 
$\mathrm{Hz}, 2 \mathrm{H}), 2.36-2.19$ (m, 2H). ${ }^{13} \mathrm{C}$ NMR (101 MHz, DMSO-d6) $\delta$ 145.2, 132.2, 129.6, $128.9,126.8,124.5,121.8,47.6,38.8,28.9,28.1 . \mathrm{m} / \mathrm{z} 397.09 \mathrm{M}+\mathrm{H}$ (calculated 398.29).

\section{PL419 (7-chloro-N-(3-(4-(4-(trifluoromethyl)phenyl)-1H-1,2,3-triazol-1-} yl)propyl)quinolin-4-amine)

To a stirred solution of PL409 (1 eq, $0.25 \mathrm{~g}, 0.95 \mathrm{mmol}$ ), 1-Ethynyl-4-(trifluoromethyl) benzene) ( $1 \mathrm{eq}, 0.16 \mathrm{ml}, 0.95 \mathrm{mmol})$ in tert-butanol $(4 \mathrm{ml}), \mathrm{CuSO}_{4} .5 \mathrm{H}_{2} \mathrm{O}(0.2 \mathrm{eq}, 0.047$ $\mathrm{g}, 0.19 \mathrm{mmol})$ and sodium ascorbate $(0.4 \mathrm{eq}, 0.075 \mathrm{~g}, 0.38 \mathrm{mmol})$ in water $(4 \mathrm{ml})$ was added and the mixture was stirred for 4 hours at $40{ }^{\circ} \mathrm{C}$. After completion, the mixture of solvents was evaporated and the solid was recrystallized by $\mathrm{CHCl}_{3}: \mathrm{MeOH}(90: 10)$ to give a pure solid (0.28 g, $68 \%) .{ }^{1} \mathrm{H}$ NMR (400 MHz, DMSO-d6) $\delta 8.77(\mathrm{~s}, 1 \mathrm{H}), 8.34$ (s, 1H), $8.04(\mathrm{~d}, \mathrm{~J}=8.0 \mathrm{~Hz}, 2 \mathrm{H}), 7.81(\mathrm{~d}, \mathrm{~J}=8.0 \mathrm{~Hz}, 2 \mathrm{H}), 7.58(\mathrm{t}, \mathrm{J}=5.3 \mathrm{~Hz}, 1 \mathrm{H}), 7.46(\mathrm{~d}, \mathrm{~J}$ $=8.8 \mathrm{~Hz}, 1 \mathrm{H}), 6.63(\mathrm{~s}, 1 \mathrm{H}), 4.60(\mathrm{t}, \mathrm{J}=6.7 \mathrm{~Hz}, 2 \mathrm{H}), 3.39(\mathrm{q}, \mathrm{J}=6.0 \mathrm{~Hz}, 2 \mathrm{H}), 2.32(\mathrm{p}, \mathrm{J}=$ $6.9 \mathrm{~Hz}, 2 \mathrm{H}) .{ }^{13} \mathrm{C}$ NMR (101 MHz, DMSO-d6) $\delta$ 144.9, 134.7, 133.8, 127.8, 125.9 - 125.7 (m), 125.6, 124.4, $122.8(\mathrm{~d}, \mathrm{~J}=9.9 \mathrm{~Hz}), 47.7,38.8,28.1 . \mathrm{m} / \mathrm{z} 431.12 \mathrm{M}+\mathrm{H}$ (calculated 431.85).

\section{PL420 (7-chloro-N-(3-(4-(4-fluorophenyl)-1H-1,2,3-triazol-1-yl)propyl)quinolin-4-} amine)

To a stirred solution of PL409 (1 eq, $0.50 \mathrm{~g}, 1.9 \mathrm{mmol}$ ), 1-Ethynyl-4-Fluorobenzene (1 eq, $0.23 \mathrm{~g}, 1.9 \mathrm{mmol})$ in tert-butanol $(5 \mathrm{ml}), \mathrm{CuSO}_{4} .5 \mathrm{H}_{2} \mathrm{O}(0.2 \mathrm{eq}, 0.095 \mathrm{~g}, 0.38 \mathrm{mmol})$ and sodium ascorbate $(0.4 \mathrm{eq}, 0.15 \mathrm{~g}, 0.76 \mathrm{mmol})$ in water $(5 \mathrm{ml})$ was added and the mixture was stirred for 4 hours at $50{ }^{\circ} \mathrm{C}$. After completion, the mixture of solvents was evaporated and the solid was recrystallized by $\mathrm{CHCl}_{3}: \mathrm{MeOH}(90: 10)$ to give a pure solid 
(0.61 g, $84 \%$ \%) ${ }^{1} \mathrm{H}$ NMR (400 MHz, DMSO-d6) $\delta 8.60$ (s, 1H), 8.45 (s, 1H), $7.92-7.81$ $(\mathrm{m}, 2 \mathrm{H}), 7.45(\mathrm{~d}, \mathrm{~J}=8.4 \mathrm{~Hz}, 2 \mathrm{H}), 7.29(\mathrm{t}, \mathrm{J}=8.8 \mathrm{~Hz}, 2 \mathrm{H}), 6.72(\mathrm{~s}, 1 \mathrm{H}), 4.57(\mathrm{t}, \mathrm{J}=6.8$ $\mathrm{Hz}, 2 \mathrm{H}), 3.44-3.29(\mathrm{~m}, 2 \mathrm{H}), 2.36-2.19(\mathrm{~m}, 2 \mathrm{H}) .{ }^{13} \mathrm{C}$ NMR (101 MHz, DMSO-d6) $\delta$ 145.5, 133.4, $127.4-126.9$ (m), 124.3, 121.4, 115.9, 115.7, 47.6, 38.8, 28.2. m/z 381.12 $\mathrm{M}+\mathrm{H}$ (calculated 381.84).

\section{PL421 (7-chloro-N-(3-(4-(4-nitrophenyl)-1H-1,2,3-triazol-1-yl)propyl)quinolin-4- amine)}

To a stirred solution of PL409 (1 eq, $0.50 \mathrm{~g}, 1.9 \mathrm{mmol}$ ), 1-Ethymyl-4-Nitrobenzene (1 eq, $0.28 \mathrm{~g}, 1.9 \mathrm{mmol})$ in tert-butanol $(5 \mathrm{ml}), \mathrm{CuSO}_{4} .5 \mathrm{H}_{2} \mathrm{O}(0.2 \mathrm{eq}, 0.095 \mathrm{~g}, 0.38 \mathrm{mmol})$ and sodium ascorbate ( $0.4 \mathrm{eq}, 0.15 \mathrm{~g}, 0.76 \mathrm{mmol})$ in water $(5 \mathrm{ml})$ was added and the mixture was stirred for 4 hours at $40{ }^{\circ} \mathrm{C}$. After completion, the mixture of solvents was evaporated and the solid was recrystallized by $\mathrm{CHCl}_{3}: \mathrm{MeOH}(90: 10)$ to give a pure solid $(0.74 \mathrm{~g}$, $95 \%) .{ }^{1} \mathrm{H}$ NMR (400 MHz, DMSO-d6) $\delta 8.85$ (s, 1H), $8.36-8.25$ (m, 3H), $8.12-8.04$ (m, 2H), $7.82(\mathrm{~s}, 1 \mathrm{H}), 7.43(\mathrm{dd}, \mathrm{J}=9.9,5.6 \mathrm{~Hz}, 2 \mathrm{H}), 6.56(\mathrm{~s}, 1 \mathrm{H}), 4.61(\mathrm{t}, \mathrm{J}=6.9 \mathrm{~Hz}$, $2 \mathrm{H}), 3.37(\mathrm{q}, \mathrm{J}=6.1 \mathrm{~Hz}, 2 \mathrm{H}), 2.37-2.12(\mathrm{~m}, 2 \mathrm{H}) .{ }^{13} \mathrm{C}$ NMR (101 MHz, DMSO-d6) $\delta$ 144.4, 125.8, $124.3(\mathrm{~d}, \mathrm{~J}=11.4 \mathrm{~Hz}), 123.6,47.9,38.8,28.9,28.1 . \mathrm{m} / \mathrm{z} 408.11 \mathrm{M}+\mathrm{H}$ (calculated 408.85).

\section{PL422 (N-benzhydrylprop-2-yn-1-amine)}

A solution of benzhydramine (1.4 eq, $3 \mathrm{ml}, 17 \mathrm{mmol})$ in anhydrous ether $(40 \mathrm{ml})$ was treated with propargyl bromide in $80 \%$ toluene $(1 \mathrm{eq}, 1.35 \mathrm{ml}, 12.2 \mathrm{eq})$, and catalytic amount of NaI. The reaction was heated with stirring at $35{ }^{\circ} \mathrm{C}$ for 16 hours. After completion, the reaction mixture was washed with water $(2 * 20 \mathrm{ml})$ and the organic layer 
was dried by anhydrous $\mathrm{MgSO}_{4}$, filtered and concentrated. The crude was purified using combi-flash chromatography in silica column by eluting in Hexanes:EtOAC (95:5) mixture to giving a pure yellow solid $(1.1 \mathrm{~g}, 42 \%) .{ }^{1} \mathrm{H}$ NMR $(400 \mathrm{MHz}$, Chloroform-d) $\delta$ $7.45-7.40(\mathrm{~m}, 4 \mathrm{H}), 7.32-7.27(\mathrm{~m}, 4 \mathrm{H}), 7.25-7.18(\mathrm{~m}, 2 \mathrm{H}), 5.10(\mathrm{~s}, 1 \mathrm{H}), 3.36(\mathrm{~d}, \mathrm{~J}=$ $2.5 \mathrm{~Hz}, 2 \mathrm{H}), 2.25(\mathrm{t}, \mathrm{J}=2.4 \mathrm{~Hz}, 1 \mathrm{H}), 1.82-1.67(\mathrm{~m}, 1 \mathrm{H})$.

\section{PL423 (N-(3-(4-((benzhydrylamino)methyl)-1H-1,2,3-triazol-1-yl)propyl)-7- chloroquinolin-4-amine)}

To a stirred solution of PL409 (1 eq, $0.55 \mathrm{~g}, 2.11 \mathrm{mmol}$ ), PL422 (1.07 eq, $0.50 \mathrm{~g}, 2.26$ mmol) in tert-butanol $(10 \mathrm{ml})$, a solution of $\mathrm{CuSO}_{4} .5 . \mathrm{H}_{2} \mathrm{O}(0.2 \mathrm{eq}, 0.10 \mathrm{~g}, 0.42 \mathrm{mmol})$ and sodium ascorbate $(0.4 \mathrm{eq}, 0.17 \mathrm{~g}, 0.84 \mathrm{mmol})$ in water $(10 \mathrm{ml})$ was added. The mixture was stirred for 4 hours at $40{ }^{\circ} \mathrm{C}$. After completion was confirmed by TLC, chloroform $(25 \mathrm{ml})$ was added and the organic layer was washed by DI-water $(3 * 125 \mathrm{ml})$, and then with brine $(50 \mathrm{ml})$. Finally, the organic layer was dried by anhydrous $\mathrm{MgSO}_{4}$, filtered and concentrated. The crude was purified in combi-flash using silica column and $\mathrm{CHCl}_{3}: \mathrm{MeOH}(95: 5)$ as eluents obtaining pure solid (0.47 g, $\left.46 \%\right) .{ }^{1} \mathrm{H} \mathrm{NMR}(400 \mathrm{MHz}$, DMSO-d6) $\delta 8.40(\mathrm{~s}, 1 \mathrm{H}), 8.28(\mathrm{~d}, \mathrm{~J}=9.1 \mathrm{~Hz}, 1 \mathrm{H}), 8.02(\mathrm{~s}, 1 \mathrm{H}), 7.80(\mathrm{~d}, 1 \mathrm{H}), 7.46(\mathrm{dd}, \mathrm{J}$ $=9.1 \mathrm{~Hz}, 1 \mathrm{H}), 7.40(\mathrm{t}, 4 \mathrm{H}), 7.35(\mathrm{t}, 1 \mathrm{H}), 7.28(\mathrm{dt}, 4 \mathrm{H}), 7.18(\mathrm{t}, 2 \mathrm{H}), 6.45(\mathrm{~d}, \mathrm{~J}=5.3 \mathrm{~Hz}$, 1H), $5.10(\mathrm{~s}, 1 \mathrm{H}), 4.83(\mathrm{~s}, 1 \mathrm{H}), 4.50(\mathrm{t}, \mathrm{J}=6.9 \mathrm{~Hz}, 2 \mathrm{H}), 3.66(\mathrm{~s}, 2 \mathrm{H}), 3.29(\mathrm{q}, \mathrm{J}=6.5 \mathrm{~Hz}$ 2H), $2.23(\mathrm{p}, \mathrm{J}=6.9 \mathrm{~Hz}, 2 \mathrm{H}) .{ }^{13} \mathrm{C}$ NMR (101 MHz, DMSO) $\delta$ 152.3, 124.6, 124.1, 123.3, $127.9,128.5,124.6,127.4,128.7,127.5,129.4,128.6,127.1,127.6,99.2,65.9,59.7$, 47.7, 42.9, 40.0, 28.9. $\mathrm{m} / \mathrm{z} 482.20 \mathrm{M}+\mathrm{H}$ (calculated 483.02). 


\section{PL424 (N-(piperidin-4-yl)-5H-cyclopenta[2,1-b:3,4-b']dipyridin-5-imine)}

To the protected amine (1 eq, $0.88 \mathrm{~g}, 2.62 \mathrm{mmol}$ ), solid $\mathrm{NaOH}$ (10 eq, $1.05 \mathrm{~g}, 26.2 \mathrm{mmol}$ ) in ethanol (20 eq, $3.1 \mathrm{ml}, 52.3 \mathrm{mmol})$ was added and stirred at room temperature for 2 hours. The solvent was evaporated, and the crude was taken by EtOAC (40 ml) and water (20 ml). The aqueous layer was extracted with $\mathrm{CHCl}_{3}(3 * 20 \mathrm{ml})$. The two organic layers

were mixed and dried with anhydrous $\mathrm{MgSO}_{4}$, filtered and concentrated to give a brownish solid (0.37 g, $42 \%) .{ }^{1} \mathrm{H}$ NMR (400 MHz, DMSO-d6) $\delta 8.67$ (ddd, J = 8.6, 4.9, $1.5 \mathrm{~Hz}, 2 \mathrm{H}), 8.11$ (dd, J = 8.0, 1.5 Hz, 1H), 7.95 (dd, J = 7.7, 1.6 Hz, 1H), 7.42 (ddd, J = 20.5, 7.7, 4.9 Hz, 2H), 4.70 (tt, J = 9.1, 4.1 Hz, 1H), 3.97 (ddd, J = 16.4, 7.8, 4.1 Hz, 2H), $3.86(\mathrm{~s}, 2 \mathrm{H}), 2.85(\mathrm{dq}, \mathrm{J}=12.3,3.7 \mathrm{~Hz}, 2 \mathrm{H}), 1.67(\mathrm{~m}, 2 \mathrm{H})$.

\section{PL425 (N-(3-(4-((5H-cyclopenta[2,1-b:3,4-b']dipyridin-5-ylidene)amino)piperidin-1-} yl)propyl)-7-chloroquinolin-4-amine)

PL424 (1.5 eq, $1.1 \mathrm{~g}, 4.16 \mathrm{mmol})$ was dissolved in acetonitrile (15 ml), and PL29 (1 eq, $0.87 \mathrm{~g}, 2.77 \mathrm{mmol})$ and $\mathrm{K}_{2} \mathrm{CO}_{3}(2 \mathrm{eq}, 0.77 \mathrm{~g}, 5.44 \mathrm{mmol})$ were all added. The reaction mixture was refluxed at $70{ }^{\circ} \mathrm{C}$ while stirring for 3 days. After completion, the solvent was evaporated and the residue was slurred in water $(30 \mathrm{ml})$ and vaccum-filtered. The crude was recrystallized from Toluene:Hexane (50:50) mixture to recover a brownish solid (0.7 g, $52 \%) .{ }^{1} \mathrm{H}$ NMR (400 MHz, DMSO-d6) $\delta 8.75(\mathrm{t}, \mathrm{J}=5.7 \mathrm{~Hz}, 4 \mathrm{H}), 8.38$ (dd, J $=27.1,6.6 \mathrm{~Hz}, 4 \mathrm{H}), 8.27(\mathrm{~d}, \mathrm{~J}=9.0 \mathrm{~Hz}, 2 \mathrm{H}), 8.14(\mathrm{~d}, \mathrm{~J}=7.5 \mathrm{~Hz}, 2 \mathrm{H}), 7.79(\mathrm{~d}, \mathrm{~J}=2.4$ $\mathrm{Hz}, 2 \mathrm{H}), 7.56-7.40(\mathrm{~m}, 10 \mathrm{H}), 7.30-7.08(\mathrm{~m}, 8 \mathrm{H}), 6.52(\mathrm{~d}, \mathrm{~J}=5.4 \mathrm{~Hz}, 2 \mathrm{H}), 4.48(\mathrm{tt}, \mathrm{J}=$ 9.4, 4.7 Hz, 2H), 3.30 (s, 6H), 2.96 (dd, J = 9.7, $5.3 \mathrm{~Hz}, 3 \mathrm{H}), 2.49$ (s, 1H), 2.29 (d, J = 6.1 
$\mathrm{Hz}, 9 \mathrm{H}), 1.97-1.78(\mathrm{~m}, 11 \mathrm{H}), 1.30-1.21(\mathrm{~m}, 1 \mathrm{H}), 0.84(\mathrm{dt}, \mathrm{J}=10.8,6.5 \mathrm{~Hz}, 1 \mathrm{H}) .{ }^{13} \mathrm{C}$ NMR (101 MHz, DMSO-d6) $\delta 160.33,158.29,155.65,152.25,151.9,151.7,150.1$, $149.1,134.9,133.3,132.9,129.7,128.9,128.2,127.5,125.3,124.6,124.4,123.9,117.4$, 98.6, 55.9, 51.3, 40.9, 32.9, 25.2, 21.0. m/z 482.20 M + H (calculated 483.02).

\section{PL426 (7-chloro-N-(pyrrolidin-3-yl)quinolin-4-amine)}

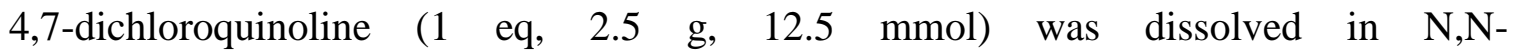
Diisopropylethylamine (50ml). 3-Aminopyrrolidine dihydrochloride (2 eq, 3.98 g, 25 mmol) and $\mathrm{CsCO}_{3}$ (4 eq, $16.45 \mathrm{~g}, 50 \mathrm{mmol}$ ) was added slowly with stirring and the mixture was refluxed for 4 hours. The solvent was evaporated and the crude was purified in combi-flash by DCM:MeOH:Et $3 \mathrm{~N}$ (8.9:1:0.1) as mixture of solvents to give orangecolored solid (1.35 g, $44 \%) .{ }^{1} \mathrm{H}$ NMR $\left(400 \mathrm{MHz}, \mathrm{CDCl}_{3}\right): \delta 8.69(\mathrm{~d}, \mathrm{~J}=4.8,1 \mathrm{H}), 8.02$ $(\mathrm{d}, \mathrm{J}=2.0,1 \mathrm{H}), 7.90(\mathrm{~d}, \mathrm{~J}=8.8,1 \mathrm{H}), 7.42(\mathrm{dd}, \mathrm{J}=8.8,2.0,1 \mathrm{H}), 6.82(\mathrm{~d}, \mathrm{~J}=4.8,1 \mathrm{H})$, $3.83(\mathrm{~m}, 1 \mathrm{H}), 3.68(\mathrm{~m}, 1 \mathrm{H}), 3.42(\mathrm{~m}, 1 \mathrm{H}), 3.14 \mathrm{~s}, 1 \mathrm{H}), 2.14(\mathrm{~m}, 1 \mathrm{H}), 1.85(\mathrm{~m}, 1 \mathrm{H})$.

\section{PL427 (N-(2-azidoethyl)-7-chloroquinolin-4-amine)}

PL30 (1 eq, $6.25 \mathrm{~g}, 20.8 \mathrm{mmol}$ ) was dissolved in dimethylformamide (65ml). Sodium azide ( $2 \mathrm{eq}, 2.70 \mathrm{~g}, 41.6 \mathrm{mmol}$ ) was added, and the reaction mixture was stirred overnight at $55{ }^{\circ} \mathrm{C}$. After completion, DI-water $(85 \mathrm{ml})$ was added and the aqueous layer was extracted with toluene $(3 * 250 \mathrm{ml})$. The organic layer was dried by anhydrous $\mathrm{MgSO}_{4}$, filtered and concentrated giving pure solid (5.02 g, $98 \%$ ). ${ }^{1} \mathrm{H}$ NMR (400 MHz, Chloroform-d) $\delta 8.54(\mathrm{~d}, \mathrm{~J}=5.4 \mathrm{~Hz}, 4 \mathrm{H}), 8.01(\mathrm{~s}, 5 \mathrm{H}), 7.96(\mathrm{~d}, \mathrm{~J}=2.2 \mathrm{~Hz}, 4 \mathrm{H}), 7.83(\mathrm{~d}, \mathrm{~J}$ $=9.0 \mathrm{~Hz}, 4 \mathrm{H}), 7.34(\mathrm{dd}, \mathrm{J}=9.0,2.2 \mathrm{~Hz}, 4 \mathrm{H}), 7.30-7.18(\mathrm{~m}, 1 \mathrm{H}), 7.17(\mathrm{dt}, \mathrm{J}=7.9,2.2$ 
$\mathrm{Hz}, 1 \mathrm{H}), 6.42(\mathrm{~d}, \mathrm{~J}=5.3 \mathrm{~Hz}, 4 \mathrm{H}), 5.94(\mathrm{t}, \mathrm{J}=5.7 \mathrm{~Hz}, 4 \mathrm{H}), 3.66(\mathrm{dd}, \mathrm{J}=6.4,5.0 \mathrm{~Hz}, 8 \mathrm{H})$, $3.53(\mathrm{q}, \mathrm{J}=5.6 \mathrm{~Hz}, 9 \mathrm{H}), 2.95(\mathrm{~s}, 14 \mathrm{H}), 2.88(\mathrm{~s}, 14 \mathrm{H}), 2.74(\mathrm{~s}, 3 \mathrm{H}), 2.35(\mathrm{~s}, 1 \mathrm{H})$.

\section{General procedure for the synthesis of terminal alkynes:}

The 10 terminal alkynes PL428, PL429, PL430, PL431, PL432, PL433, PL434, PL435, PL436 and PL437 were prepared according to the following procedure:

To a mixture of $\mathrm{N}$-substituted piperazine (1 eq, $3.2 \mathrm{mmol})$ and anhydrous $\mathrm{K}_{2} \mathrm{CO}_{3}(1 \mathrm{eq}$, $0.44 \mathrm{~g}, 3.2 \mathrm{mmol})$ in anhydrous acetonitrile $(5 \mathrm{~mL})$, propargyl bromide $(80 \% \mathrm{~W} / \mathrm{V}$ solution in toluene, $1 \mathrm{eq}, 0.36 \mathrm{ml}, 3.2 \mathrm{mmol}$ ) was added. The mixture was stirred overnight under reflux, and then filtered and evaporated. The residue was purified by combiflash chromatography using silica column eluting by Hexanes:EtOAc mixture.

\section{PL428 (2-(4-(prop-2-yn-1-yl)piperazin-1-yl)pyrimidine)}

$0.21 \mathrm{~g}, 32 \% .{ }^{1} \mathrm{H}$ NMR (400 MHz, DMSO-d6) $\delta 8.47$ (dd, J = 11.1, 2 Hz, 11H), 6.79 (dt, $\mathrm{J}=14.5,4.9 \mathrm{~Hz}, 1 \mathrm{H}), 4.68(\mathrm{~s}, 2 \mathrm{H}), 4.17(\mathrm{~s}, 1 \mathrm{H}), 4.14(\mathrm{dd}, \mathrm{J}=13.0,8.0 \mathrm{~Hz}, 4 \mathrm{H}), 3.67(\mathrm{t}, \mathrm{J}$ $=5.1 \mathrm{~Hz}, 4 \mathrm{H})$.

\section{PL429 (1-(prop-2-yn-1-yl)-4-(4-(trifluoromethyl)benzyl)piperazine)}

$0.78 \mathrm{~g}, 87 \% .{ }^{1} \mathrm{H}$ NMR (400 MHz, Chloroform-d) $\delta 7.56$ (dd, 2H), 7.47 (dd, J = 11.2, 8.0 $\mathrm{Hz}, 2 \mathrm{H}), 3.96(\mathrm{t}, \mathrm{J}=5.1 \mathrm{~Hz}, 2 \mathrm{H}), 3.56(\mathrm{~d}, \mathrm{~J}=18.7 \mathrm{~Hz}, 2 \mathrm{H}), 3.30(\mathrm{~d}, \mathrm{~J}=2.5 \mathrm{~Hz}, 2 \mathrm{H}), 3.09$ $-2.93(\mathrm{~m}, 2 \mathrm{H}), 2.68-2.58(\mathrm{~m}, 4 \mathrm{H}), 2.26(\mathrm{t}, \mathrm{J}=2.4 \mathrm{~Hz}, 1 \mathrm{H})$. 


\section{PL430 (1-(prop-2-yn-1-yl)-4-(p-tolyl)piperazine)}

0.68 g, $99 \% .{ }^{1} \mathrm{H}$ NMR (400 MHz, Chloroform-d) $\delta 7.14-7.02(\mathrm{~m}, 2 \mathrm{H}), 6.93-6.74(\mathrm{~m}$, $2 \mathrm{H}), 3.45-3.23(\mathrm{~m}, 2 \mathrm{H}), 3.22-3.10(\mathrm{~m}, 4 \mathrm{H}), 2.78-2.70(\mathrm{~m}, 4 \mathrm{H}), 2.27(\mathrm{~d}, \mathrm{~J}=6.0 \mathrm{~Hz}$, $3 \mathrm{H})$.

\section{PL431 (1-(prop-2-yn-1-yl)-4-(pyridin-2-yl)piperazine)}

$0.45 \mathrm{~g}, 70 \% .{ }^{1} \mathrm{H}$ NMR (400 MHz, Chloroform-d) $\delta 8.19$ (tt, J = 4.9, $\left.2.1 \mathrm{~Hz}, 1 \mathrm{H}\right), 7.63-$ $7.43(\mathrm{~m}, 1 \mathrm{H}), 6.86-6.59(\mathrm{~m}, 2 \mathrm{H}), 4.12-3.95(\mathrm{~m}, 2 \mathrm{H}), 3.90(\mathrm{t}, \mathrm{J}=5.2 \mathrm{~Hz}, 2 \mathrm{H}), 3.71-$ $3.44(\mathrm{~m}, 2 \mathrm{H}), 3.36(\mathrm{~d}, \mathrm{~J}=2.5 \mathrm{~Hz}, 2 \mathrm{H}), 2.73-2.65(\mathrm{~m}, 2 \mathrm{H}), 2.28(\mathrm{t}, \mathrm{J}=2.5 \mathrm{~Hz}, 1 \mathrm{H})$.

\section{PL432 (1-(4-(oxo- $\lambda^{6}$-methyl)phenyl)-4-(prop-2-yn-1-yl)piperazine)}

1-(4-methoxyphenyl)-piperazine dihydrochloride (1 eq, 2 g, $7.5 \mathrm{mmol}$ ) was dissolved in water (20ml), and solid $\mathrm{NaHCO}_{3}(2.3 \mathrm{eq}, 1.4 \mathrm{~g}, 17.1 \mathrm{mmol})$ was added with stirring. After addition of dichloromethane $(25 \mathrm{ml})$, the aqueous phase was extracted with DCM (3*25ml) and the organic phase was dried by anhydrous $\mathrm{MgSO}_{4}$, filtered and concentrated by rotovap to give the free base starting material.

$0.7 \mathrm{~g}, 95 \% .{ }^{1} \mathrm{H}$ NMR (400 MHz, Chloroform-d) $\delta 7.02-6.78(\mathrm{~m}, 4 \mathrm{H}), 3.76(\mathrm{~d}, \mathrm{~J}=2.5$ $\mathrm{Hz}, 3 \mathrm{H}), 3.36(\mathrm{~d}, \mathrm{~J}=2.5 \mathrm{~Hz}, 2 \mathrm{H}), 3.17-2.98(\mathrm{~m}, 4 \mathrm{H}), 2.78-2.55(\mathrm{~m}, 4 \mathrm{H}), 2.28(\mathrm{t}, \mathrm{J}=$ $2.4 \mathrm{~Hz}, 1 \mathrm{H})$. 


\section{PL433 (1-phenyl-4-(prop-2-yn-1-yl)piperazine)}

$0.56 \mathrm{~g}, 88 \% .{ }^{1} \mathrm{H}$ NMR (400 MHz, Chloroform-d) $\delta 7.33-7.20$ (m, 2H), $6.98-6.80$ (m, $3 \mathrm{H}), 3.36(\mathrm{~d}, \mathrm{~J}=2.5 \mathrm{~Hz}, 2 \mathrm{H}), 3.27-3.20(\mathrm{~m}, 4 \mathrm{H}), 2.77-2.70(\mathrm{~m}, 4 \mathrm{H}), 2.28(\mathrm{t}, \mathrm{J}=2.4$ $\mathrm{Hz}, 1 \mathrm{H})$.

\section{PL434 (4-(4-(prop-2-yn-1-yl)piperazin-1-yl)phenol)}

$0.39 \mathrm{~g}, 57 \% .{ }^{1} \mathrm{H}$ NMR (400 MHz, DMSO-d6) $\delta 6.91-6.59(\mathrm{~m}, 4 \mathrm{H}), 4.62(\mathrm{~d}, \mathrm{~J}=2.6 \mathrm{~Hz}$, 2H), $4.15(\mathrm{t}, 1 \mathrm{H}), 3.68(\mathrm{t}, \mathrm{J}=5.0 \mathrm{~Hz}, 2 \mathrm{H}), 3.39(\mathrm{t}, \mathrm{J}=4.8 \mathrm{~Hz}, 2 \mathrm{H}), 3.17(\mathrm{~s}, 1 \mathrm{H}), 3.13-$ $3.01(\mathrm{~m}, 4 \mathrm{H})$.

\section{PL435 (1-(4-chlorophenyl)-4-(prop-2-yn-1-yl)piperazine)}

$0.5 \mathrm{~g}, 67 \% .{ }^{1} \mathrm{H}$ NMR (400 MHz, Chloroform-d) $\delta 7.27-7.15(\mathrm{~m}, 2 \mathrm{H}), 6.91-6.78(\mathrm{~m}$, 2H), $3.37(\mathrm{~d}, \mathrm{~J}=2.4 \mathrm{~Hz}, 2 \mathrm{H}), 3.26-3.16(\mathrm{~m}, 4 \mathrm{H}), 2.78-2.69(\mathrm{~m}, 4 \mathrm{H}), 2.28(\mathrm{t}, \mathrm{J}=2.5$ $\mathrm{Hz}, 1 \mathrm{H})$.

\section{PL436 (1-cyclohexyl-4-(prop-2-yn-1-yl)piperazine)}

$0.57 \mathrm{~g}, 86 \% .{ }^{1} \mathrm{H}$ NMR (400 MHz, Chloroform-d) $\delta 3.34$ (d, J = 2.5 Hz, 2H), 3.10 (dtd, 4H), $2.42-2.26(\mathrm{~m}, 3 \mathrm{H}), 1.95(\mathrm{~m}, 2 \mathrm{H}), 1.53(\mathrm{qd}, \mathrm{J}=12.1,3.4 \mathrm{~Hz}, 4 \mathrm{H}), 1.27(\mathrm{~m}, 6 \mathrm{H})$.

\section{PL437 (1-(3,4-dichlorophenyl)-4-(prop-2-yn-1-yl)piperazine)}

0.81 g, 94 \%. ${ }^{1} \mathrm{H}$ NMR (400 MHz, Chloroform-d) $\delta 7.39-7.22(\mathrm{~m}, 1 \mathrm{H}), 7.01-6.84$ (m, 1H), $6.74(\mathrm{ddd}, \mathrm{J}=8.9,4.9,2.9 \mathrm{~Hz}, 1 \mathrm{H}), 3.41-3.29(\mathrm{~m}, 2 \mathrm{H}), 3.25-3.10(\mathrm{~m}, 4 \mathrm{H}), 2.80-$ $2.68(\mathrm{~m}, 4 \mathrm{H}), 2.29(\mathrm{t}, \mathrm{J}=2.4 \mathrm{~Hz}, 1 \mathrm{H})$. 


\section{PL439 $\left(\mathrm{N}^{1}, \mathrm{~N}^{3}\right.$-bis(7-chloroquinolin-4-yl)propane-1,3-diamine)}

To PL426 (1.5 eq, $0.88 \mathrm{~g}, 3.57 \mathrm{mmol})$ dissolved in acetonitrile (30ml), PL29 (1 eq, 0.75 $\mathrm{g}, 2.38 \mathrm{mmol}$ ) and cesium carbonate ( $2 \mathrm{eq}, 1.55 \mathrm{~g}, 4.76 \mathrm{mmol}$ ) was added. The reaction mixture was refluxed for 3 days. The solvent was evaporated and the crude was slurred in water $(80 \mathrm{ml})$ in a sonicator for 30 minutes. The solid was filtered by vaccum-filtration and purified on silica column using combi-flash chromatography eluting by EtOAC:MeOH. One of the peaks (collection 3) was collected and concentrated to give a yellow solid (0.1 g, $67 \%) .{ }^{1} \mathrm{H}$ NMR (400 MHz, Chloroform-d) $\delta 8.74$ (d, J = 5.2 Hz, 1H), $8.58-8.43(\mathrm{~m}, 1 \mathrm{H}), 8.12(\mathrm{~d}, \mathrm{~J}=8.9 \mathrm{~Hz}, 1 \mathrm{H}), 8.05(\mathrm{~d}, \mathrm{~J}=2.0 \mathrm{~Hz}, 1 \mathrm{H}), 8.01-7.91$ $(\mathrm{m}, 1 \mathrm{H}), 7.66(\mathrm{~d}, \mathrm{~J}=9.0 \mathrm{~Hz}, 1 \mathrm{H}), 7.45(\mathrm{dd}, \mathrm{J}=8.9,2.1 \mathrm{~Hz}, 1 \mathrm{H}), 7.40-7.26(\mathrm{~m}, 1 \mathrm{H})$, $6.73(\mathrm{~d}, \mathrm{~J}=5.3 \mathrm{~Hz}, 1 \mathrm{H}), 6.49(\mathrm{~d}, \mathrm{~J}=5.4 \mathrm{~Hz}, 1 \mathrm{H}), 5.43(\mathrm{~s}, 1 \mathrm{H}), 4.38(\mathrm{t}, \mathrm{J}=5.6 \mathrm{~Hz}, 2 \mathrm{H})$, $3.69(\mathrm{q}, \mathrm{J}=6.3 \mathrm{~Hz}, 2 \mathrm{H}), 2.43(\mathrm{p}, \mathrm{J}=6.3 \mathrm{~Hz}, 2 \mathrm{H}) . \mathrm{m} / \mathrm{z} 397.08 \mathrm{M}+\mathrm{H}$ (calculated 397.30).

\section{General procedure for the synthesis of piperazine-linked triazoles:}

The 9 compounds PL440, PL441, PL442, PL443, PL444, PL445, PL446, PL447 and PL448 were prepared according to the following procedure:

To a stirred solution of PL409 (1 eq, $0.25 \mathrm{~g}, 0.95 \mathrm{mmol}$ ) and synthesized N-piperazinylsubstituted terminal alkynes $(1.05 \mathrm{eq}, 1.0 \mathrm{mmol})$ in tert-butanol $(6.8 \mathrm{ml}), \mathrm{CuSO}_{4} .5 \mathrm{H}_{2} \mathrm{O}$ (0.1 eq, $0.024 \mathrm{~g}, 0.095 \mathrm{mmol})$ and sodium ascorbate $(0.2 \mathrm{eq}, 0.038 \mathrm{~g}, 0.19 \mathrm{mmol})$ in water $(2.3 \mathrm{ml})$ was added. The mixture was stirred for 48 hours at $50{ }^{\circ} \mathrm{C}$. After completion, the mixture of solvents was evaporated and the solid was purified using combi-flash chromatography in silica column by eluting using $\mathrm{CHCl}_{3}: \mathrm{MeOH}$ (90:10). 
PL440 (7-chloro-N-(3-(4-((4-(pyrimidin-2-yl)piperazin-1-yl)methyl)-1H-1,2,3triazol-1-yl)propyl)quinolin-4-amine)

$0.32 \mathrm{~g}, 70 \% .{ }^{1} \mathrm{H}$ NMR (400 MHz, DMSO-d6) $\delta 8.39$ (d, J = 5.4 Hz, 1H), $8.34(\mathrm{~d}, \mathrm{~J}=4.8$ Hz, 2H), $8.26(\mathrm{~d}, \mathrm{~J}=9.0 \mathrm{~Hz}, 1 \mathrm{H}), 8.07(\mathrm{~s}, 1 \mathrm{H}), 7.79(\mathrm{~d}, \mathrm{~J}=2.3 \mathrm{~Hz}, 1 \mathrm{H}), 7.47$ (dd, J = 9.0, $2.0 \mathrm{~Hz}, 1 \mathrm{H}), 7.35(\mathrm{t}, \mathrm{J}=5.4 \mathrm{~Hz}, 1 \mathrm{H}), 6.61(\mathrm{t}, \mathrm{J}=4.8 \mathrm{~Hz}, 1 \mathrm{H}), 6.42(\mathrm{~d}, \mathrm{~J}=5.4 \mathrm{~Hz}, 1 \mathrm{H})$, $4.49(\mathrm{t}, \mathrm{J}=6.9 \mathrm{~Hz}, 2 \mathrm{H}), 3.69(\mathrm{t}, \mathrm{J}=5.0 \mathrm{~Hz}, 4 \mathrm{H}), 3.60(\mathrm{~s}, 2 \mathrm{H}), 3.28(\mathrm{q}, \mathrm{J}=6.5 \mathrm{~Hz}, 2 \mathrm{H})$, $2.44(\mathrm{t}, \mathrm{J}=5.0 \mathrm{~Hz}, 4 \mathrm{H}), 2.24(\mathrm{~h}, \mathrm{~J}=7.4,7.0 \mathrm{~Hz}, 2 \mathrm{H}) .{ }^{13} \mathrm{C} \mathrm{NMR}(101 \mathrm{MHz}, \mathrm{DMSO}-\mathrm{d} 6) \delta$ $157.1,141.3,136.2,129.7,123.9,110.1,52.0,47.2,43.4,38.9,28.2(\mathrm{~d}, \mathrm{~J}=20.9 \mathrm{~Hz}) . \mathrm{m} / \mathrm{z}$ 463.20 M + H (calculated 463.97).

PL441 (7-chloro-N-(3-(4-((4-(4-(trifluoromethyl)benzyl)piperazin-1-yl)methyl)-1H1,2,3-triazol-1-yl)propyl)quinolin-4-amine)

0.16 g, $52 \% .{ }^{1} \mathrm{H}$ NMR (400 MHz, DMSO-d6) $\delta 8.39$ (d, J = 5.4 Hz, 1H), $8.26(\mathrm{~d}, \mathrm{~J}=9.0$ $\mathrm{Hz}, 1 \mathrm{H}), 8.01(\mathrm{~s}, 1 \mathrm{H}), 7.79(\mathrm{~d}, \mathrm{~J}=2.3 \mathrm{~Hz}, 1 \mathrm{H}), 7.66(\mathrm{~d}, \mathrm{~J}=8.0 \mathrm{~Hz}, 2 \mathrm{H}), 7.50$ (d, J = 8.0 $\mathrm{Hz}, 2 \mathrm{H}), 7.47(\mathrm{dd}, \mathrm{J}=9.0,2.0 \mathrm{~Hz}, 1 \mathrm{H}), 7.36(\mathrm{t}, \mathrm{J}=5.3 \mathrm{~Hz}, 1 \mathrm{H}), 6.41(\mathrm{~d}, \mathrm{~J}=5.5 \mathrm{~Hz}, 1 \mathrm{H})$, $4.49(\mathrm{t}, \mathrm{J}=6.9 \mathrm{~Hz}, 2 \mathrm{H}), 3.54(\mathrm{~d}, \mathrm{~J}=5.2 \mathrm{~Hz}, 4 \mathrm{H}), 3.27(\mathrm{q}, \mathrm{J}=6.5 \mathrm{~Hz}, 2 \mathrm{H}), 2.36(\mathrm{~s}, 8 \mathrm{H})$, $2.22(\mathrm{p}, \mathrm{J}=6.9 \mathrm{~Hz}, 2 \mathrm{H}) .{ }^{13} \mathrm{C} \mathrm{NMR}(101 \mathrm{MHz}, \mathrm{DMSO}-\mathrm{d} 6) \delta 151.7,150.0,148.8,143.2$, $133.5,129.3,127.3,125.0,124.2,124.0,123.9,120.9,117.4,98.7,61.2,52.4,52.1,47.2$, 28.4. $\mathrm{m} / \mathrm{z} 543.22 \mathrm{M}+\mathrm{H}$ (calculated 544.02).

PL442 (7-chloro-N-(3-(4-((4-(p-tolyl)piperazin-1-yl)methyl)-1H-1,2,3-triazol-1yl)propyl)quinolin-4-amine)

0.17 g, $35 \% .{ }^{1} \mathrm{H}$ NMR (400 MHz, DMSO-d6) $\delta 8.40$ (d, J = 5.4 Hz, 1H), 8.26 (d, J = 9.0 $\mathrm{Hz}, 1 \mathrm{H}), 8.06(\mathrm{~s}, 1 \mathrm{H}), 7.80(\mathrm{~s}, \mathrm{~J}=2.3 \mathrm{~Hz}, 1 \mathrm{H}), 7.47(\mathrm{dd}, \mathrm{J}=9.0,2.0 \mathrm{~Hz}, 1 \mathrm{H}), 7.37$ (t, J = 
$5.2 \mathrm{~Hz}, 1 \mathrm{H}), 7.00(\mathrm{~d}, \mathrm{~J}=8.3 \mathrm{~Hz}, 2 \mathrm{H}), 6.84-6.76(\mathrm{~m}, 2 \mathrm{H}), 6.42(\mathrm{t}, \mathrm{J}=6.4 \mathrm{~Hz}, 1 \mathrm{H}), 4.49$ $(\mathrm{q}, \mathrm{J}=6.8 \mathrm{~Hz}, 2 \mathrm{H}), 3.60(\mathrm{~s}, 2 \mathrm{H}), 3.27(\mathrm{~s}, 2 \mathrm{H}), 3.06-2.99(\mathrm{~m}, 4 \mathrm{H}), 2.50(\mathrm{~d}, \mathrm{~J}=1.8 \mathrm{~Hz}$, 4H), $2.38(\mathrm{~d}, \mathrm{~J}=13.8 \mathrm{~Hz}, 2 \mathrm{H}), 2.32-2.16(\mathrm{~m}, 3 \mathrm{H}) .{ }^{13} \mathrm{C}$ NMR (101 MHz, DMSO-d6) $\delta$ $151.0,150.0,133.5,128.9,124.2,118.8,115.3,52.2,48.1,47.3,28.4 . \mathrm{m} / \mathrm{z} 475.23 \mathrm{M}+\mathrm{H}$ (calculated 476.03).

PL443 (7-chloro-N-(3-(4-((4-(pyridin-2-yl)piperazin-1-yl)methyl)-1H-1,2,3-triazol-1yl)propyl)quinolin-4-amine)

$0.28 \mathrm{~g}, 61 \% .{ }^{1} \mathrm{H}$ NMR (400 MHz, DMSO-d6) $\delta 8.43-8.37$ (m, 1H), 8.27 (d, J = $9.0 \mathrm{~Hz}$, 1H), $8.17-8.05(\mathrm{~m}, 2 \mathrm{H}), 7.80(\mathrm{~d}, \mathrm{~J}=2.3 \mathrm{~Hz}, 1 \mathrm{H}), 7.56-7.39(\mathrm{~m}, 3 \mathrm{H}), 6.79(\mathrm{~d}, \mathrm{~J}=8.6$ $\mathrm{Hz}, 1 \mathrm{H}), 6.62(\mathrm{dd}, \mathrm{J}=7.0,4.9 \mathrm{~Hz}, 1 \mathrm{H}), 6.44(\mathrm{~d}, \mathrm{~J}=5.5 \mathrm{~Hz}, 1 \mathrm{H}), 4.50(\mathrm{t}, \mathrm{J}=6.9 \mathrm{~Hz}, 2 \mathrm{H})$, $3.60(\mathrm{~s}, 2 \mathrm{H}), 3.44(\mathrm{t}, \mathrm{J}=4.9 \mathrm{~Hz}, 4 \mathrm{H}), 3.29(\mathrm{~s}, 2 \mathrm{H}), 2.47(\mathrm{~d}, \mathrm{~J}=5.0 \mathrm{~Hz}, 4 \mathrm{H}), 2.23(\mathrm{p}, \mathrm{J}=$ $6.9 \mathrm{~Hz}, 2 \mathrm{H}) .{ }^{13} \mathrm{C}$ NMR (101 MHz, DMSO-d6) $\delta$ 147.5, 137.5, 124.3, 113.0, 107.1, 47.3, 40.1, 38.8, 28.3. $\mathrm{m} / \mathrm{z} 462.21 \mathrm{M}+\mathrm{H}$ (calculated 462.99).

\section{PL444 (7-chloro-N-(3-(4-((4-(4-methoxyphenyl)piperazin-1-yl)methyl)-1H-1,2,3- triazol-1-yl)propyl)quinolin-4-amine)}

$0.37 \mathrm{~g}, 76 \% .{ }^{1} \mathrm{H}$ NMR (400 MHz, DMSO-d6) $\delta 8.41(\mathrm{~s}, 1 \mathrm{H}), 8.29(\mathrm{~d}, \mathrm{~J}=9.1 \mathrm{~Hz}, 1 \mathrm{H})$, $8.06(\mathrm{~s}, 1 \mathrm{H}), 7.80(\mathrm{~d}, \mathrm{~J}=2.3 \mathrm{~Hz}, 1 \mathrm{H}), 7.55-7.46(\mathrm{~m}, 2 \mathrm{H}), 6.90-6.75(\mathrm{~m}, 4 \mathrm{H}), 6.46(\mathrm{~d}, \mathrm{~J}$ $=5.4 \mathrm{~Hz}, 1 \mathrm{H}), 4.50(\mathrm{t}, \mathrm{J}=6.8 \mathrm{~Hz}, 2 \mathrm{H}), 3.68(\mathrm{~d}, \mathrm{~J}=9.3 \mathrm{~Hz}, 3 \mathrm{H}), 3.60(\mathrm{~s}, 2 \mathrm{H}), 3.24-3.15$ $(\mathrm{m}, 2 \mathrm{H}), 2.97(\mathrm{t}, \mathrm{J}=4.9 \mathrm{~Hz}, 4 \mathrm{H}), 2.53(\mathrm{~d}, \mathrm{~J}=4.9 \mathrm{~Hz}, 4 \mathrm{H}), 2.24(\mathrm{p}, \mathrm{J}=6.9 \mathrm{~Hz}, 2 \mathrm{H}) .{ }^{13} \mathrm{C}$ NMR (101 MHz, DMSO-d6) $\delta 124.3,117.3,114.2,55.1,38.8 . \mathrm{m} / \mathrm{z} 491.22 \mathrm{M}+\mathrm{H}$ (calculated 492.02). 
PL445 (7-chloro-N-(3-(4-((4-phenylpiperazin-1-yl)methyl)-1H-1,2,3-triazol-1yl)propyl)quinolin-4-amine)

$0.32 \mathrm{~g}, 70 \% .{ }^{1} \mathrm{H}$ NMR (400 MHz, DMSO-d6) $\delta 8.40$ (d, J = 5.4 Hz, 1H), $8.34-8.23$ (m, 1H), $8.07(\mathrm{~s}, 1 \mathrm{H}), 7.80(\mathrm{~d}, \mathrm{~J}=2.3 \mathrm{~Hz}, 1 \mathrm{H}), 7.47(\mathrm{dd}, \mathrm{J}=9.0,2.2 \mathrm{~Hz}, 1 \mathrm{H}), 7.37(\mathrm{t}, \mathrm{J}=5.3$ $\mathrm{Hz}, 1 \mathrm{H}), 7.27-7.14(\mathrm{~m}, 2 \mathrm{H}), 6.90(\mathrm{~d}, \mathrm{~J}=8.2 \mathrm{~Hz}, 2 \mathrm{H}), 6.76(\mathrm{t}, \mathrm{J}=7.2 \mathrm{~Hz}, 1 \mathrm{H}), 6.43(\mathrm{~d}, \mathrm{~J}$ $=5.4 \mathrm{~Hz}, 1 \mathrm{H}), 4.51(\mathrm{t}, \mathrm{J}=6.9 \mathrm{~Hz}, 2 \mathrm{H}), 3.60(\mathrm{~s}, 2 \mathrm{H}), 3.27(\mathrm{~d}, \mathrm{~J}=6.5 \mathrm{~Hz}, 2 \mathrm{H}), 3.08(\mathrm{t}, \mathrm{J}=$ $4.9 \mathrm{~Hz}, 4 \mathrm{H}), 2.52(\mathrm{t}, \mathrm{J}=4.9 \mathrm{~Hz}, 4 \mathrm{H}), 2.24(\mathrm{p}, \mathrm{J}=6.9 \mathrm{~Hz}, 2 \mathrm{H}) .{ }^{13} \mathrm{C} \mathrm{NMR}(101 \mathrm{MHz}$, DMSO-d6) $\delta 151.0,150.0,133.5,128.9,124.2,118.8,115.3,52.2,48.1,47.3,28.4 . \mathrm{m} / \mathrm{z}$ 461.21 M + H (calculated 462.00).

PL446 (4-(4-((1-(3-((7-chloroquinolin-4-yl)amino)propyl)-1H-1,2,3-triazol-4yl)methyl)piperazin-1-yl)phenol)

$0.33 \mathrm{~g}, 68 \% .{ }^{1} \mathrm{H}$ NMR (400 MHz, DMSO-d6) $\delta 8.79(\mathrm{~s}, 1 \mathrm{H}), 8.42-8.23(\mathrm{~m}, 3 \mathrm{H}), 8.06$ $(\mathrm{d}, \mathrm{J}=5.2 \mathrm{~Hz}, 1 \mathrm{H}), 7.79(\mathrm{~d}, \mathrm{~J}=2.3 \mathrm{~Hz}, 1 \mathrm{H}), 7.47(\mathrm{dd}, \mathrm{J}=9.0,2.2 \mathrm{~Hz}, 1 \mathrm{H}), 7.36(\mathrm{t}, \mathrm{J}=$ $5.5 \mathrm{~Hz}, 1 \mathrm{H}), 6.84-6.70(\mathrm{~m}, 1 \mathrm{H}), 6.67-6.57(\mathrm{~m}, 1 \mathrm{H}), 6.42(\mathrm{~d}, \mathrm{~J}=5.4 \mathrm{~Hz}, 1 \mathrm{H}), 4.50(\mathrm{td}$ $\mathrm{J}=6.9,2.1 \mathrm{~Hz}, 2 \mathrm{H}), 3.69(\mathrm{t}, \mathrm{J}=5.0 \mathrm{~Hz}, 2 \mathrm{H}), 3.59(\mathrm{~d}, \mathrm{~J}=3.8 \mathrm{~Hz}, 2 \mathrm{H}), 2.91(\mathrm{t}, \mathrm{J}=4.9 \mathrm{~Hz}$

4H), $2.44(\mathrm{t}, \mathrm{J}=5.1 \mathrm{~Hz}, 2 \mathrm{H}), 2.23(\mathrm{p}, \mathrm{J}=6.9 \mathrm{~Hz}, 2 \mathrm{H}) .{ }^{13} \mathrm{C}$ NMR $(101 \mathrm{MHz}$, DMSO-d6) $\delta$ 157.8, 149.8, 133.5, $124.12(\mathrm{~d}, \mathrm{~J}=11.1 \mathrm{~Hz}), 117.7,115.4,56.6,52.4$, 49.8, 47.3, 38.7, 28.4. $\mathrm{m} / \mathrm{z}$ 477.21 M + H (calculated 478.00).

PL447 (7-chloro-N-(3-(4-((4-(4-chlorophenyl)piperazin-1-yl)methyl)-1H-1,2,3triazol-1-yl)propyl)quinolin-4-amine)

$0.40 \mathrm{~g}, 80 \% .{ }^{1} \mathrm{H}$ NMR (400 MHz, DMSO-d6) $\delta 8.80(\mathrm{~s}, 1 \mathrm{H}), 8.42-8.36(\mathrm{~m}, 3 \mathrm{H}), 8.27$ $(\mathrm{d}, \mathrm{J}=9.1 \mathrm{~Hz}, 3 \mathrm{H}), 8.06(\mathrm{~d}, \mathrm{~J}=2.2 \mathrm{~Hz}, 3 \mathrm{H}), 7.79(\mathrm{~d}, \mathrm{~J}=2.3 \mathrm{~Hz}, 3 \mathrm{H}), 7.47(\mathrm{dd}, \mathrm{J}=9.0$ 
$2.2 \mathrm{~Hz}, 4 \mathrm{H}), 7.36(\mathrm{t}, \mathrm{J}=5.1 \mathrm{~Hz}, 4 \mathrm{H}), 7.28-7.17(\mathrm{~m}, 4 \mathrm{H}), 7.00-6.87(\mathrm{~m}, 4 \mathrm{H}), 6.79-$ $6.70(\mathrm{~m}, 2 \mathrm{H}), 6.67-6.58(\mathrm{~m}, 2 \mathrm{H}), 6.42(\mathrm{~d}, \mathrm{~J}=5.4 \mathrm{~Hz}, 3 \mathrm{H}), 5.78-5.73(\mathrm{~m}, 1 \mathrm{H}), 4.50(\mathrm{t}$, $\mathrm{J}=6.9 \mathrm{~Hz}, 2 \mathrm{H}), 3.59(\mathrm{~d}, \mathrm{~J}=3.7 \mathrm{~Hz}, 2 \mathrm{H}), 3.26(\mathrm{~s}, 2 \mathrm{H}), 3.08(\mathrm{t}, \mathrm{J}=5.0 \mathrm{~Hz}, 4 \mathrm{H}), 2.91(\mathrm{dd}, \mathrm{J}$ $=9.5,4.5 \mathrm{~Hz}, 2 \mathrm{H}), 2.52(\mathrm{~s}, 2 \mathrm{H}), 2.24(\mathrm{~h}, \mathrm{~J}=6.7 \mathrm{~Hz}, 2 \mathrm{H}) .{ }^{13} \mathrm{C}$ NMR $(101 \mathrm{MHz}$, DMSOd6) $\delta 150.2,149.7,133.7,128.5,127.5,127.1,124.2(\mathrm{~d}, \mathrm{~J}=8.4 \mathrm{~Hz}), 123.9,122.3,116.8$, 52.4, 52.0, 47.9, 47.3, 38.8, 28.4. $\mathrm{m} / \mathrm{z} 495.17 \mathrm{M}+\mathrm{H}$ (calculated 496.44).

\section{PL448 (7-chloro-N-(3-(4-((4-(3,4-dichlorophenyl)piperazin-1-yl)methyl)-1H-1,2,3- triazol-1-yl)propyl)quinolin-4-amine)}

$0.41 \mathrm{~g}, 77 \% .{ }^{1} \mathrm{H}$ NMR (400 MHz, DMSO-d6) $\delta 8.40(\mathrm{~s}, 1 \mathrm{H}), 8.27(\mathrm{~d}, \mathrm{~J}=9.0 \mathrm{~Hz}, 1 \mathrm{H})$, $8.06(\mathrm{~s}, 1 \mathrm{H}), 7.79(\mathrm{~d}, \mathrm{~J}=2.3 \mathrm{~Hz}, 1 \mathrm{H}), 7.51-7.34(\mathrm{~m}, 3 \mathrm{H}), 7.10(\mathrm{~d}, \mathrm{~J}=2.9 \mathrm{~Hz}, 1 \mathrm{H}), 7.00$ $-6.87(\mathrm{~m}, 1 \mathrm{H}), 6.43(\mathrm{~d}, \mathrm{~J}=5.4 \mathrm{~Hz}, 1 \mathrm{H}), 4.50(\mathrm{t}, \mathrm{J}=6.9 \mathrm{~Hz}, 2 \mathrm{H}), 3.56(\mathrm{~d}, \mathrm{~J}=26.0 \mathrm{~Hz}$, 2H), $3.32-3.24(\mathrm{~m}, 2 \mathrm{H}), 3.13(\mathrm{t}, \mathrm{J}=5.0 \mathrm{~Hz}, 4 \mathrm{H}), 2.56(\mathrm{~s}, 4 \mathrm{H}), 2.24(\mathrm{~h}, \mathrm{~J}=6.6 \mathrm{~Hz}, 2 \mathrm{H})$. ${ }^{13}$ C NMR (101 MHz, DMSO-d6) $\delta$ 156.2, 152.2, 150.3, 133.5, 128.0, 127.2, 126.1, $125.7,124.1,123.9,109.4,52.0,51.7,47.3,38.9,28.3 . \mathrm{m} / \mathrm{z} 530.14 \mathrm{M}+\mathrm{H}$ (calculated $530.88)$.

PL456 (7-chloro-N-(3-(4-((4-(7-chloroquinolin-4-yl)piperazin-1-yl)methyl)-1H-1,2,3triazol-1-yl)propyl)quinolin-4-amine)

The purified PL467 (1.07 eq, $1.15 \mathrm{~g}, 4.02 \mathrm{mmol})$ and PL409 (1 eq, $0.99 \mathrm{~g}, 3.76 \mathrm{mmol}$ ) dissolved in tert-butanol $(15 \mathrm{ml})$ were mixed with $\mathrm{CuSO}_{4} .5 \mathrm{H}_{2} \mathrm{O}(0.15 \mathrm{eq}, 0.14 \mathrm{~g}, 0.56$ mmol $)$ and sodium ascorbate $(0.3 \mathrm{eq}, 0.22 \mathrm{~g}, 1.13 \mathrm{mmol})$ in water $(5 \mathrm{ml})$ for 24 hours at $50{ }^{\circ} \mathrm{C}$. After evaporating the solvent, the crude was purified using combi-flash chromatography on silica by eluting in $\mathrm{CHCl}_{3}: \mathrm{MeOH}$ (90:10) to give the target 
compound (1.2 g, $57 \%) .{ }^{1} \mathrm{H}$ NMR (400 MHz, CDCl3) $\delta 8.70(\mathrm{~d}, \mathrm{~J}=5.0 \mathrm{~Hz}, 1 \mathrm{H}), 8.47(\mathrm{~d}$, $\mathrm{J}=5.3 \mathrm{~Hz}, 1 \mathrm{H}), 8.03(\mathrm{~d}, \mathrm{~J}=2.1 \mathrm{~Hz}, 1 \mathrm{H}), 7.94(\mathrm{~d}, \mathrm{~J}=2.2 \mathrm{~Hz}, 1 \mathrm{H}), 7.91(\mathrm{~d}, \mathrm{~J}=8.9 \mathrm{~Hz}$ 1H), $7.75(\mathrm{~d}, \mathrm{~J}=9.0 \mathrm{~Hz}, 1 \mathrm{H}), 7.57(\mathrm{~s}, 1 \mathrm{H}), 7.41(\mathrm{dd}, \mathrm{J}=9.0,2.1 \mathrm{~Hz}, 1 \mathrm{H}), 7.40$ (dd, J = 9.0, $2.3 \mathrm{~Hz}, 1 \mathrm{H}), 6.80(\mathrm{~d}, \mathrm{~J}=5.0 \mathrm{~Hz}, 1 \mathrm{H}), 6.36(\mathrm{~d}, \mathrm{~J}=5.4 \mathrm{~Hz}, 1 \mathrm{H}), 5.87(\mathrm{t}, \mathrm{J}=5.5 \mathrm{~Hz}$, 1H), $4.57(\mathrm{t}, \mathrm{J}=6.2 \mathrm{~Hz}, 2 \mathrm{H}), 3.78(\mathrm{~s}, 2 \mathrm{H}), 3.47(\mathrm{~d}, 2 \mathrm{H}), 3.20(\mathrm{t}, 4 \mathrm{H}), 2.77(\mathrm{t}, 4 \mathrm{H}), 2.39(\mathrm{p}$ $\mathrm{J}=6.5 \mathrm{~Hz}, 2 \mathrm{H}) .13 \mathrm{C}$ NMR (101 MHz, DMSO-d6) $\delta 156.8,151.8,150.9,150.1,149.8$, $144.8,135.5,134.9,128.8,126.2,125.8,125.1,123.6,123.2,121.9,121.5,108.9,98.6$, 53.2, 52.8, 51.9, 48.1, 40.3, 28.3. m/z 547.19 M + H (calculated 547.49).

\section{PL457 (7-chloro-4-isothiocyanatoquinoline)}

A mixture of 4,7-dichloroquinoline (1 eq, $1.8 \mathrm{~g}, 9.09 \mathrm{mmol})$ and silverthiocyanate (2 eq, $3.02 \mathrm{~g}, 18.18 \mathrm{mmol})$ was stirred in anhydrous toluene $(15 \mathrm{ml})$ for 12 hours. The reaction was carried in disposable screw cap culture tube $(100 \mathrm{ml})$ using fishr PTFE disposable bar stirrer. The hot mixture was filtered and the filtrate was washed with chloroform $(3 *$ $37.5 \mathrm{ml})$ and concentrated by rotovap to give a yellow solid $(1.88 \mathrm{~g}, 94 \%) .{ }^{1} \mathrm{H}$ NMR (400 MHz, Chloroform-d) $\delta 8.86(\mathrm{~d}, \mathrm{~J}=4.7 \mathrm{~Hz}, 1 \mathrm{H}), 8.12(\mathrm{~d}, \mathrm{~J}=2.0 \mathrm{~Hz}, 1 \mathrm{H}), 8.03(\mathrm{~d}, \mathrm{~J}$ $=8.9 \mathrm{~Hz}, 1 \mathrm{H}), 7.58(\mathrm{dd}, \mathrm{J}=8.9,2.1 \mathrm{~Hz}, 1 \mathrm{H}), 7.26(\mathrm{~d}, \mathrm{~J}=4.7 \mathrm{~Hz}, 1 \mathrm{H})$.

\section{PL459 (Methyl (3-((7-chloroquinolin-4-yl)amino)propyl)carbamodithioate)}

The intermediate product was synthesized in one-pot reaction by dissolving PL107 (1 eq, $2.0,8.49 \mathrm{mmol})$ in dimethylsulfoxide $(4 \mathrm{ml})$ and stirring at room temperature. Carbon disulfide (1.25 eq, $0.64 \mathrm{ml}, 10.61 \mathrm{mmol})$ and $10 \% \mathrm{NaOH}(1.25 \mathrm{eq}, 3.78 \mathrm{ml}, 10.61 \mathrm{mmol})$ were added dropwise over 30 minutes. Then the mixture was stirred for another 30 
minutes. After 1 hour, dimethylsulfate ( $1 \mathrm{eq}, 0.81 \mathrm{ml}, 8.49 \mathrm{mmol}$ ) was added at $5-10{ }^{\circ} \mathrm{C}$, and the stirring continued for 3 hours. The sticky-brownish suspension formed was added to ice-water $(50 \mathrm{ml})$ and transferred to sep-funnel. The aqueous layer was extracted by chloroform $(3 * 20 \mathrm{ml})$. The organic layer was washed by saturated $\mathrm{NaHCO}_{3}(25 \mathrm{ml})$ and then salted out by brine $(20 \mathrm{ml})$. Finally the organic layer was dried by anhydrous $\mathrm{MgSO}_{4}$, filtered and concentrated to give brownish solid (0.8 g, $\left.30 \%\right) .{ }^{1} \mathrm{H}$ NMR (400 MHz, DMSO-d6) $\delta 9.99$ (t, J = 5.2 Hz, 1H), 8.40 (d, J = 5.4 Hz, 1H), 8.25 (d, J = 9.0 Hz, $1 \mathrm{H}), 7.80(\mathrm{~d}, \mathrm{~J}=2.3 \mathrm{~Hz}, 1 \mathrm{H}), 7.52-7.27(\mathrm{~m}, 2 \mathrm{H}), 6.49(\mathrm{t}, \mathrm{J}=6.0 \mathrm{~Hz}, 1 \mathrm{H}), 3.66(\mathrm{dtd}, \mathrm{J}=$ 43.9, 6.9, 4.3 Hz, 2H), $3.32(\mathrm{q}, \mathrm{J}=6.6 \mathrm{~Hz}, 2 \mathrm{H}), 2.52(\mathrm{~d}, \mathrm{~J}=2.4 \mathrm{~Hz}, 3 \mathrm{H}), 1.99(\mathrm{~m}, 2 \mathrm{H})$.

\section{PL460 (Ethyl 4-((5H-cyclopenta[2,1-b:3,4-b']dipyridin-5-ylidene)amino)piperidine- 1-carboxylate)}

1,8-Diazafluoren-9-one (1 eq, $0.5 \mathrm{~g}, 2.74 \mathrm{mmol}$ ) and Ethyl-4-amino-1-piperidine carboxylate (1.15 eq, $0.54 \mathrm{ml}, 3.15 \mathrm{mmol})$ was dissolved in anhydrous toluene $(15 \mathrm{ml})$. Catalytic amount of p-toluene-sulfonic acid was added and the reaction was performed using dean-stark apparatus to remove the water continuously forming as a by-product. The reaction was refluxed stirring for 3 days. After the mixture was cooled to RT, the solvent was evaporated, and the crude was used in the next reaction prior to purification (0.88 g, $96 \%) .{ }^{1} \mathrm{H}$ NMR (400 MHz, DMSO-d6) $\delta 8.75$ (ddd, J = 8.6, 4.9, $1.5 \mathrm{~Hz}, 2 \mathrm{H}$ ), $8.42(\mathrm{dd}, \mathrm{J}=8.0,1.5 \mathrm{~Hz}, 1 \mathrm{H}), 8.12(\mathrm{dd}, \mathrm{J}=7.7,1.6 \mathrm{~Hz}, 1 \mathrm{H}), 7.49(\mathrm{ddd}, \mathrm{J}=20.5,7.7,4.9$ $\mathrm{Hz}, 2 \mathrm{H}), 4.70(\mathrm{tt}, \mathrm{J}=9.1,4.1 \mathrm{~Hz}, 1 \mathrm{H}), 4.09(\mathrm{q}, \mathrm{J}=7.1 \mathrm{~Hz}, 2 \mathrm{H}), 3.99(\mathrm{ddd}, \mathrm{J}=16.4,7.8$, $4.1 \mathrm{~Hz}, 2 \mathrm{H}), 3.27(\mathrm{~s}, 2 \mathrm{H}), 1.91(\mathrm{dq}, \mathrm{J}=12.3,3.7 \mathrm{~Hz}, 2 \mathrm{H}), 1.80-1.62(\mathrm{~m}, 2 \mathrm{H}), 1.20(\mathrm{dt}, \mathrm{J}$ $=16.9,7.1 \mathrm{~Hz}, 3 \mathrm{H})$. 


\section{PL467 (7-chloro-4-(4-(prop-2-yn-1-yl)piperazin-1-yl)quinoline)}

PL49 (1 eq, $2.5 \mathrm{~g}, 10.1 \mathrm{mmol}$ ), propargyl bromide in $80 \% \mathrm{~W} / \mathrm{V}$ toluene $(1 \mathrm{eq}, 0.96 \mathrm{ml}$, $10.1 \mathrm{mmol})$ and $\mathrm{K}_{2} \mathrm{CO}_{3}(1 \mathrm{eq}, 1.4 \mathrm{~g}, 10.1 \mathrm{mmol})$ in acetonitrile $(15 \mathrm{ml})$ were refluxed for 48 hours. After the completion of the reaction was confirmed by TCL on alumina plate using EtOAC:MeOH (90:10) as eluents, the solvent was evaporated by rotovap. The crude was taken up by dichloromethane $(40 \mathrm{ml})$ and washed by saturated $\mathrm{NaHCO}_{3}(3 *$ $20 \mathrm{ml})$. All the aqueous phase were mixed and and extracted by DCM (30 ml). The two organic phases were mixed and dried by anhydrous $\mathrm{MgSO}_{4}$, filtered and concentrated. The crude was purified using combi-flash chromatography on silica using Hexanes:EtOAC as eluents give brownish solid (2.41 g, $83 \%) .{ }^{1} \mathrm{H}$ NMR (400 MHz, CDCl3) $\delta 8.71(\mathrm{~d}, \mathrm{~J}=5.0 \mathrm{~Hz}, 1 \mathrm{H}), 8.03(\mathrm{~d}, \mathrm{~J}=2.1 \mathrm{~Hz}, 1 \mathrm{H}), 7.94(\mathrm{~d}, \mathrm{~J}=8.9 \mathrm{~Hz}, 1 \mathrm{H}), 7.41$ $(\mathrm{dd}, \mathrm{J}=9.0,2.1 \mathrm{~Hz}, 1 \mathrm{H}), 6.83(\mathrm{~d}, \mathrm{~J}=5.0 \mathrm{~Hz}, 1 \mathrm{H}), 3.44(\mathrm{~d}, 2 \mathrm{H}), 3.27(\mathrm{t}, 4 \mathrm{H}), 2.86(\mathrm{t}, 4 \mathrm{H})$, $2.35(\mathrm{t}, 1 \mathrm{H})$.

\subsection{In Vitro Drug Susceptibility Assays}

Both CQS (D6) and CQR (Dd2 and 7G8) P. falciparum maintained continuously in culture were used. Asynchronous cultures were diluted with uninfected RBCs and complete medium (RPMI-1640 with $0.5 \%$ Albumax II) to achieve $0.2 \%$ parasitemia and $2 \%$ hematocrit. In 96-well microplates, CQ (positive control) or click compounds diluted in complete medium from $10 \mathrm{mM}$ stock in DMSO were added to the cell mixture to yield triplicate wells with drug concentrations ranging from 0 to $10^{-4} \mathrm{M}$ in a final well volume of $100 \mu \mathrm{L}$. After $72 \mathrm{~h}$ of incubation under standard culture conditions, plates were 
harvested and read by the SYBR Green I fluorescence-based method using a 96-well fluorescence plate reader (Gemini-EM, Molecular Devices), with excitation and emission wavelengths at 497 and $520 \mathrm{~nm}$, respectively. The fluorescence readings were plotted against $\log [\mathrm{drug}]$, and the $\mathrm{IC}_{50}$ values were obtained from curve fitting performed by nonlinear regression using either Prism (GraphPad) or Excel (Microsoft) software. The values obtained for each cell line are normalized to CQ values of $5.9 \mathrm{nM}$ for D6, $54 \mathrm{nM}$ for $\mathrm{Dd} 2$, and $57 \mathrm{nM}$ for $7 \mathrm{G} 8$. Errors were estimated to be $\pm 30 \%$. This was determined by looking at the variability in $\mathrm{IC}_{50}$ values of 4 compounds, each with 3 or 4 sets of results per $\mathrm{IC}_{50}$ determination, and by taking into account the estimated uncertainties resulting from the weighing of the compounds. 


\section{REFERENCES}

1. Bogitsh B. J., Carter C. E., Oeltmann T. N., Human Parasitology, $3^{\text {rd }}$ edition, academic press publishers, February 2005

2. WHO Malaria fact sheet, $\mathbf{2 0 1 5}$

3. Centers for disease control and prevention, www.cdc.gov/malaria/about/facts.html

4. Cox F. E., History of the discovery of the malaria parasites and their vectors, Parasites \& Vectors 2010, 3, 5

5. Gunn A., Jane S. P., Parasitology: An Integrated Approach, wiley, April 2012

6. Collins W. E., Jeffery G. M., Plasmodium malariae: Parasite and Disease, Clinical microbiology reviews, 2007, 20 (4), 579-592

7. Cox-Singh J., Davis T. M., Lee K. S., Shamsul S. G., Matusop A., Ratnam S., Rahman H. A., Conway D. J., Singh B., Plasmodium knowlesi Malaria in humans Is Widely distributed and Potentially Life Threatening, Clinical Infectious Diseases 2008; 46, 165-71

8. Castelli F., Odolini S., Autino B., Foca E., Russo R., Malaria prophylaxis: a comprehensive review, Pharmaceuticals, 2010, 3, 3212-3239

9. Winzeler E. A., Malaria research in the post-genomic era, Nature, 2008, 455, 751756

10. Vargas Parada, L., The Apicoplast: An Organelle with a Green Past, Nature Education, 2010, 3(9), 10

11. Malaria, Parasite Biology, Cdc. Gov/dpdx/malaria/indx.html

12. Whitfield J., Portrait of a serial killer, Nature, october 2012

13. Mankhambo L., Phiri A., Mallewa M., Molyneux M., Management of severe malaria, Therapy, 2010, 7(1), 27-38 
14. Cahill K. M., International Humanitarian Affairs: Tropical medicine: A clinical text, $8^{\text {th }}$ edition, Fordham University Press, 2011

15. Maltha J., Jacobs J., Clinical practice: The diagnosis of imported malaria in children, Eur. J. Pediatr., 2011, 170, 821-829

16. Bell D., Wongsrichanalai C., Barnwell J.W., Ensuring quality and access for malaria diagnosis: how can it be achieved? ,Nature reviews, 2006, 4, 682-695

17. The malERA Consultative Group on Diagnoses and Diagnostics, A Research Agenda for Malaria Eradication: Diagnoses and Diagnostics, PNoS Medicine, 2011, 8(1), 1-10

18. The malERA Consultative Group on Integration Strategies, A Research Agenda for Malaria Eradication: Cross-Cutting Issues for Eradication, PLoS, 2011, 8(1), $1-6$

19. WHO expert committee on Malaria, $20^{\text {th }}$ report, 2000

20. Greenwood B. M., Bojang K., Whitty C. J.,Targett G. A., Malaria, Lancet, 2005, $365,1487-1498$

21. White N. J., Pukrittayakamee S., Hien T. T., Faiz M. A., Mokuolu O.A., Dondorp A. M., Malaria, Lancet, 2014, 383, 723-735

22. Karunamoorthi K., Vector control: A cornerstone in the malaria elimination campaign, Clin. mic. \& inf., 2011, 17(11), 1608-1616

23. Karunamoorthi K., Ilangoc K., Endale A., Ethnobotanical survey of knowledge and usage custom of traditional insect/mosquito repellent plants among the Ethiopian Oromo ethnic group, J. Ethnopharmacology, 125, 2009, 224-229

24. Holt R. A., Subramanian G. M., Halpern A., Sutton G. G., The Genome Sequence of the Malaria Mosquito Anopheles gambiae, Science, 2002, 298(4), 129-149

25. Shanks G. D., Edstein M. D., Modern malaria chemoprophylaxis, Drugs, 2005, 65(15), 2091-2110 
26. RTS,S Clinical Trials Partnership, Efficacy and safety of RTS,S/AS01 malaria vaccine with or without a booster dose in infants and children in Africa: Final results of a phase 3, individually randomised, controlled trial, Lancet, 2015, 385, 1581

27. Ritter J. M., Textbook of Clinical Pharmacology and Therapeutics, $5^{\text {th }}$ edition, 2008

28. Enayati A., Hemingway J., Malaria Management: Past, Present, and Future, Ann. Rev. Entomol., 2010, 55, 569-591

29. Daily J. P., Antimalarial Drug Therapy: The Role of Parasite Biology and Drug Resistance, J. Clin. Phar., 2006, 46, 1487-1497

30. Sitoe A. R., Lopes F., Moreira R., Coelho A., Bronze M. R., Contribution of Mass Spectrometry to the Study of Antimalarial Agents,

http://dx.doi.org/10.5772/56225

31. Guidelines for the treatment of Malaria, $3^{\text {rd }}$ edition, Geneva, Switherland, 2015

32. Delves M., Plouffe D., Scheurer C., Meister S., Wittlin S., Winzeler E. A., Sinden R. E., Leroy D., The Activities of Current Antimalarial Drugs on the Life Cycle Stages of Plasmodium: A Comparative Study with Human and Rodent Parasites, PLoS Medicine, 2012, 9(2), 1-14

33. Mzayek F., Deng H., Mather F. J., Wasilevich E. C., Liu H., Hadi C. M., Chansolme D. H., Murphy H. A., Melek B. H., Tenaglia A. N., Mushatt D. M., Dreisbach A. W., Lertora J. J., Krogstad D. J., Randomized Dose-Ranging Controlled Trial of AQ-13, a Candidate Antimalarial, and Chloroquine in Healthy Volunteers, PLoS Clinical Trials, 2007, e6, 0001-0015

34. O’Neill P. M., Park B. K., Shone A. E., Maggs J. L. et al., Candidate Selection and Preclinical Evaluation of N-tert-Butyl Isoquine (GSK369796), An Affordable and Effective 4-Aminoquinoline Antimalarial for the 21st Century, 2009, 52, $1408-1415$

35. Marcsisin S. R., Sousa J. C., Reichard G. A., Caridha D. et al., Tafenoquine and NPC-1161B require CYP 2D metabolism for anti-malarial activity: implications 
for the 8-aminoquinoline class of anti-malarial compounds, Malaria Journal, 2014, 13(2), 1-9

36. Charmana S. A., Arbe-Barnesb S., Bathurstc I. C., Brun R. et al., Synthetic ozonide drug candidate OZ439 offers new hope for a single-dose cure of uncomplicated malaria, PNAS, 2011, 108(11), 4400-4405

37. Malarial dihydrofolate reductase as a paradigm for drug development against a resistance-compromised target Yuthavonga Y., Tarnchompooa B., Vilaivanb T., Chitnumsuba P. et al., PNAS, 2012, 109(42), 16823-16828

38. White N. J., Pukrittayakamee S., Phyo A. P., Rueangweerayut R. et al., Spiroindolone KAE609 for Falciparum and Vivax Malaria, N. Eng. J. Med., 2014, 371(5), 403-410

39. Baird J. K., Effectiveness of Antimalarial Drugs, N. Eng. J. Med., 2005, 352, 1565-1577

40. Wongsrichanalai C., Pickard A. L., Wernsdorfer W. H., Meshnick S. R., Epidemiology of drug-resistant malaria, The Lancet inf. Dis., 2002, 2(4), 209-218

41. Noedl H., Se Y., Schaecher K., Smith B. L., Socheat D., Fukuda M. M., Evidence of Artemisinin-Resistant Malaria in Western Cambodia, N. Eng. J. Med., 2008, 359(24), 2619-2620

42. Hyde J. E., Drug-resistant malaria, Trends in Parasitology, 2005, 21(11), 494-498

43. Krafts K., Hempelmann E., Skórska-Stania A., From methylene blue to chloroquine: a brief review of the development of an antimalarial therapy, Parasitol. Res., 2012, 111, 1-6

44. Hempelmann E., Hemozoin Biocrystallization in Plasmodium falciparum and the antimalarial activity of crystallization inhibitors, Parasitol Res., 2007, 100, 671676

45. Cooper R. G., Magwere T., Chloroquine: Novel uses \& manifestations, Indian J Med Res, 2008, 127, 305-316 
46. Sanchez C. P., Stein W. D., Lanzer M., Is PfCRT a channel or a carrier? Two competing models explaining chloroquine resistance in Plasmodium falciparum, TRENDS in Parasitology, 2007, 23(7), 332-339

47. Bray P. G., Martin R. E., Tilley L., Ward S. A., Kirk K., Fidock D. A., Defining the role of PfCRT in Plasmodium falciparum chloroquine resistance, Molecular Microbiology, 2005, 56 (2), 323-333

48. Mushtaque M. S., Reemergence of chloroquine (CQ) analogs as multi-targeting antimalarial agents: A review, Eur. J. Med. Chem., 2015, 90, 280-295

49. Warhurst D., New developments: Chloroquine-resistance in Plasmodium falciparum, Drug Resistance updates, 2001, 4, 141-144

50. Wellems T. E., Plowe C. V., Chloroquine-Resistant Malaria, J. Inf. Dis., 2001, 184 (6), 770-776

51. Schlitzer M., Ortmann R., Feeding the Antimalarial Pipeline, Chem. Med. Chem., 2010, 5, 1837-1840

52. Krogstad D. J., Gluzman I. Y., Kyle D. E., Oduola A. M., Martin S. K., Milhous W. K., Schlesinger P. H., Efflux of Chloroquine from Plasmodium falciparum: Mechanism of Chloroquine Resistance, Science, 1987, 238 (4831), 1283-1285

53. Bitonti A. J., Sjoerdsma A., McCann P. P., Kyle D. E., Oduola A. M., Rossan R. N., Milhous W. K., Davidson D. E., Reversal of Chloroquine Resistance in Malaria Parasite Plasmodium falciparum by Desipramine, Science, 1988, 242 (4883), 1301-1303

54. Gerena L., Bass G. T., Kyle D. E., Oduola A. M., Milhous W. K., Martin R. K., Fluoxetine Hydrochloride Enhances In Vitro Susceptibility to Chloroquine in Resistant Plasmodium falciparum, Antimicrobial Agents and Chemotherapy, 1992, 36 (12), 2761-2765

55. Basco L. K., Bras J. L., In vitro reversal of chloroquine resistance with chlorpheniramine against african isolates of plasmodium falciparum, Jpn. J. Med. Sci. Biol., 1994, 47, 59-63 
56. Oduola A. M., Sowunmi A., Milhous W. K., Brewer T. G., Kyle D. E., Gerena L., Rossan R. N., Salako L. A., Schuster B. G., In vitro and in vivo reversal of chloroquine resistance in plasmodium falciparum with promethazine, Am. J. Trop. Med. Hyg., 1998, 58(5), 625-629

57. Van Schalkwyk D. A., Walden J. C., Smith P. J., Reversal of Chloroquine Resistance in Plasmodium falciparum Using Combinations of Chemosensitizers, Antimicrobial agents and chemotherapy, 2001, 45(11), 3171-3174

58. Bray P. G, Deed S., Fox E., Kalkanidis M., Mungthin M., Deady L. W., Tilley L., Primaquine synergises the activity of chloroquine against chloroquine-resistant $\mathrm{P}$. falciparum, Biochem. Phar., 2005, 70, 1158-1166

59. Lehane A. M., Kirk K., Efflux of a range of antimalarial drugs and 'chloroquine resistance reversers' from the digestive vacuole in malaria parasites with mutant PfCRT, Molecular Microbiology, 2010, 77(4), 1039-1051

60. Bhattacharjee A. K., Kyle D. E., Vennerstrom J. L., Milhous W. K., A 3D QSAR Pharmacophore Model and Quantum Chemical Structure-Activity Analysis of Chloroquine(CQ)-Resistance Reversal, J. Chem. Inf. Comput. Sci., 2002, 42, 1212-1220

61. Bhattacharjee A. K., Kyle D. E., Vennerstrom J. L., Structural Analysis of Chloroquine Resistance Reversal by Imipramine Analogs, Antimicrobial agents and chemotherapy, 2001, 45(9), 2655-2657

62. Burgess S. J., Selzer A., Kelly J. X., Smilkstein M. J., Riscoe M. K., Peyton D. H., A Chloroquine-like Molecule Designed to Reverse Resistance in Plasmodium falciparum, J. Med. Chem., 2006, 49, 5623-5625

63. Burgess S. J., Kelly J. X., Shomloo S., Wittlin S., Brun R., Liebmann K., Peyton D. H., Synthesis, Structure-Activity Relationship, and Mode-of-Action Studies of Antimalarial Reversed Chloroquine Compounds, J. Med. Chem., 2010, 53, 64776489

64. Peyton D. H., Reversed Chloroquine Molecules as a Strategy to Overcome Resistance in Malaria, Current Topics in Medicinal Chemistry, 2012, 12, 400-407 
65. Kolb H. C., Finn M. G., Sharpless K. B., Click Chemistry: Diverse Chemical Function from a Few Good Reactions, Angew. Chem. Int. Ed., 2001, 40, $2004-$ 2021

66. Eycken E. V., Sharpless K. B., Click Chemistry, QSAR Comb. Sci., 2007, 26 (1112), 1115

67. Hein C. D., Liu X. M., Wang D., Click Chemistry, a Powerful Tool for Pharmaceutical Sciences, Pharm Res., 2008, 25(10), 2216-2230

68. Finn M. G., Fokin V. V., Click chemistry: function follows form, Chem. Soc. Rev., 2010, 39, 1231-1232

69. Kolb H. C., Sharpless K. B., The growing impact of click chemistry on drug discovery, Res. focus reviews, 2003, 8 (24), 1128-1137

70. Roper S., Kolb H. C., Click chemistry for drug discovery, Wiley-Vch Verlag Gmbh \& Co., 2006

71. Huisgen R. et al., 1,3-dipolar cycloadditions XXXII, kinetics of the addition of organic azides to carbon-carbon multiple bonds, Chem. Ber., 1967, 100, 24942507

72. Wang Q., Hawker C., Toward a Few Good Reactions: Celebrating Click Chemistry's First Decade, Chem. Asian J., 2011, 6, 2568 - 2569

73. Padwa A., Pearson W. H., Synthetic applications of 1,3-dipolar cycloaddition chemistry toward heterocycles and natural products, The Chemistry of Heterocyclic Compounds, Volume 59, 2002, John Wiley \& Sons, Inc.

74. Tron G. C., Pirali T., Billington R. A., Canonico P. L., Sorba G., Genazzani A. A., Click Chemistry Reactions in Medicinal Chemistry: Applications of the 1,3dipolar Cycloaddition Between Azides and Alkynes, Med Res Rev, 2008, 28 (2), 278-308

75. Imperio D., Pirali T., Galli U., Pagliai F., Cafici L., Canonico P. L., Sorba G., Genazzani A. A., Tron G. C., Replacement of the lactone moiety on podophyllotoxin and steganacin analogues with a 1,5-disubstituted 1,2,3-triazole 
via ruthenium-catalyzed click chemistry, Bio. \& Med. Chem., 2007, 15, 67486757

76. Agalave S. G., Maujan S. R., Pore V. S., Click Chemistry: 1,2,3-Triazoles as Pharmacophores, Chem. Asian J., 2011, 6, 2696 - 2718

77. Rostovtsev V. V., Green L. G., Fokin V. V., Sharpless K. B., A Stepwise Huisgen Cycloaddition Process: Copper (I)-Catalyzed Regioselective "Ligation" of Azides and Terminal Alkynes, Angew. Chem. Int. Ed., 2002, 41 (14), 2596 - 2599

78. Himo F., Lovell T., Hilgraf R., Rostovtsev V. V., Noodleman L., Sharpless K. B., Fokin V. V., Copper(I)-Catalyzed Synthesis of Azoles. DFT Study Predicts Unprecedented Reactivity and Intermediates, J. Am. Chem. Soc., 2005, 127, 210216

79. Liang L., Astruc D., The copper(I)-catalyzed alkyne-azide cycloaddition (CuAAC) "click" reaction and its applications. An overview, Coordination Chemistry Reviews, 2011, 255, 2933-2945

80. Tornøe C. W., Christensen C., Meldal M., Peptidotriazoles on Solid Phase: [1,2,3]-Triazoles by Regiospecific Copper(I)-Catalyzed 1,3-Dipolar Cycloadditions of Terminal Alkynes to Azides, J. Org. Chem., 2002, 67, 30573064

81. Moorhouse A. D., Moses J. E., Click Chemistry and Medicinal Chemistry: A Case of "Cyclo-Addiction", Chem. Med. Chem., 2008, 3, 715 - 723

82. Moses J. E., Moorhouse A. D., The growing applications of click chemistry, Chem. Soc. Rev., 2007, 36, 1249-1262

83. Nandivada H., Jiang X., Lahann G., Click Chemistry: Versatility and Control in the Hands of Materials Scientists, Adv. Mater., 2007, 19, 2197-2208

84. Wu P., Feldman A. K., Nugent A. K., Hawker C. J., Scheel A., Voit B., Pyun J., Frechet J. M., Sharpless K. B., Fokin V. V., Efficiency and Fidelity in a ClickChemistry Route to Triazole Dendrimers by the Copper(i)- Catalyzed Ligation of Azides and Alkynes, Angew. Chem. Int. Ed., 2004, 43, 3928 -3932 
85. Lee L. V., Mitchell M. L., Huang S. J., Fokin V. V., Sharpless K. B., Wong C. H., A Potent and Highly Selective Inhibitor of Human r-1,3-Fucosyltransferase via Click Chemistry, J. Am., Chem. Soc., 2003, 125, 9588-9589

86. Pisaneschi F., Nguyen Q. D., Shamsaei E., Glaser M., Robins E., Kaliszczak M., Smith G., Spivey A. C., Aboagye E. O., Development of a new epidermal growth factor receptor positron emission tomography imaging agent based on the 3cyanoquinoline core: Synthesis and biological evaluation, Bio. \& Med. Chem., 2010, 18, 6634-6645

87. Kandi S. K., Manohar S., Gerena C. V., Zayas B., Malhotra S. V., Rawat D. S., $\mathrm{C}_{5}$-curcuminoid-4-aminoquinoline based molecular hybrids: design, synthesis and mechanistic investigation of anticancer activity, New J. Chem., 2015, 39, 224 234

88. Sumangala V., Poojary B., Chidananda N., Fernandes J. and Kumari N. S., Synthesis and antimicrobial activity of 1,2,3-triazoles containing quinoline moiety, Archives of Pharmacal Research, 2010 , 33 (12), 1911-1918.

89. Holla B. S., Mahalinga M., Karthikeyan M. S., Poojary B., Akberali P. M., Kumari N. S., Synthesis, characterization and antimicrobial activity of some substituted 1,2,3-triazoles, Eur. J. Med. Chem., 2005, 40, 1173-1178

90. Thomas K. D., Adhikari A. V., Shetty N. S., Design, synthesis and antimicrobial activities of some new quinoline derivatives carrying 1,2,3-triazole moiety, Eur. J. Med. Chem., 2010, 45, 3803 - 3810

91. Olomola T. O., Klein R., Lobb K. A., Sayed Y., Kaye P. T., Towards the synthesis of coumarin derivatives as potential dual-action HIV-1 protease and reverse transcriptase inhibitors, Tetrahedron Letters, 2010, 51, 6325-6328

92. Manohar S., Khan S. I., Rawat D. S., Synthesis of 4-aminoquinoline-1,2,3-triazole and 4-aminoquinoline-1,2,3-triazole-1,3,5-triazine Hybrids as Potential Antimalarial Agents, Chem. Biol. Drug Des., 2011, 78, 124 - 136

93. Mamgain R., Atheaya H., Khan S. I., Manohar S., Rawat D. S., Synthesis of novel 1,2,3-triazole incorporated quinoline derivatives via click chemistry and evaluation of their antimalarial activity, J. Ind. Chem. Soc., 2014, 91, 1443 - 1450 
94. Guilherme R. Pereira a, Geraldo Célio Brandão b, Lucas M. Arantes c, Oliveira H. A., Paula R. C., Nascimento M. F., Santos F. M., Rocha R. K., Lopes J. C., Oliveira A. B., 7-Chloroquinolinotriazoles: Synthesis by the azideealkyne cycloaddition click chemistry, antimalarial activity, cytotoxicity and SAR studies, Eur. J. Med. Chem., 2014, 73, 295 - 309

95. Hamann A. R., Kock C., Smith P. J., Otterlo W. A., Blackie M. A., Synthesis of novel triazole-linked mefloquine derivatives: Biological evaluation against Plasmodium falciparum, Bio. \& Med. Chem. Lett., 2014, 24, 5466-5469

96. Raj R., Singh P., Singh P., Gut J., Rosenthal P. J., Kumar V., Azide-alkyne cycloaddition en route to 1H-1,2,3-triazole-tethered 7-chloroquinoline-isatin chimeras: Synthesis and antimalarial evaluation, Eur. J. Med. Chem., 2013, 62, $590-596$

97. Singh P., Singh P., Kumar M., Gut J., Rosenthal P. J., Kumar K., Kumar V., Mahajan M. P., Bisetty K., Synthesis, docking and in vitro antimalarial evaluation of bifunctional hybrids derived from b-lactams and 7-chloroquinoline using click chemistry, Bio. \& Med. Chem. Lett., 2012, 22, 57 - 61

98. Singh P., Sachdeva S., Raj R., Kumar V., Mahajan M. P., Nasser S., Vivas L., Gut J., Rosenthal P. J., Feng T. S., Chibale K., Antiplasmodial and cytotoxicity evaluation of 3-functionalized 2-azetidinone derivatives, Bio. \& Med. Chem. Lett., 2011, 21, $4561-4563$

99. Tome A. C., Product Class 13: 1,2,3-Triazoles, Science of Synthesis, 2004, Georg Thieme Verlag KG

100. Schulzeab B., Schubert U. S., Beyond click chemistry - supramolecular interactions of 1,2,3-triazoles, Chem. Soc. Rev., 2014, 43, 2522

101. Moorhouse A. D., Santos A. M., Gunaratnam M., Moore M., Neidle S., Moses J. E., Stabilization of G-Quadruplex DNA by Highly Selective Ligands via Click Chemistry, J. Am. Chem. Soc., 2006, 128, 15972 - 15973

102. Kauffmann T., Protophanes and Polyarenes. 4. The arenology principle, Angewchem. Int. ed. Engl., 1971, 10, 743-744 
103. Bachl J., Mayr J., Sayago F. J., Cativielab C., Diaz D. D., Amide-triazole isosteric substitution for tuning self-assembly and incorporating new functions into soft supramolecular materials, DOI: 10.1039/c4cc08593k

104. Phillips O. A., Udo E. E., Alic A. A., Hassawia N. A., Synthesis and Antibacterial Activity of 5-Substituted Oxazolidinones, Bio. \& Med. Chem., 2003, 11, $35-41$

105. Peterson L. B., Blagg B. S., Click chemistry to probe Hsp90: Synthesis and evaluation of a series, of triazole-containing novobiocin analogues, Bio. \& Med. Chem. Lett., 2010, 20, 3957 - 3960

106. MoltZen E. K., Pedersen H. E., Bogeso K. P., Meier D., Frederiksen K., Sanchez C., Lembal H. L., Bioisosteres of Arecoline: 1,2,3,6-Tetrahydro-5pyridyl-Substituted and 3-Piperidyl-Substituted Derivatives of Tetrazoles and 1,2,3-Triazoles. Synthesis and Muscarinic Activity, J. Med. Chem., 1994, 37, $4085-4099$

107. Hou J, Liu X., Shen J., Zhao G., Wang P. G., The impact of click chemistry in medicinal chemistry, Expert Opin. Drug Discov., 2012, 7 (6), 489 501

108. Durrant J. D., McCammon J. A., AutoClickChem: Click Chemistry in Silico, PLoS Computational Biology, 2012, 8 (3), 1 - 7

109. Starcevic K., Pesic D., Toplak A., Landek G., Alihodzic S., Herreros E., Ferrer S., Spaventi R., Peric M., Novel hybrid molecules based on 15-membered azalide as potential antimalarial agents, Eur. J. Med. Chem., 2012, 49, 365 - 378

110. Manohar S., Khan S. I., Rawat D. S., Synthesis of 4-aminoquinoline-1,2,3triazole and 4-aminoquinoline-1,2,3-triazole-1,3,5-triazine Hybrids as Potential Antimalarial Agents, Chem. Biol. Drug Des., 2011, 78, 124 - 136

111. Gunsaru, Bornface, "Simplified Reversed Chloroquines to Overcome Malaria Resistance to Quinoline-based Drugs" (2010). Dissertations and Theses. Paper 400.

112. Castagnetti E., Schlosser M., The Trifluoromethoxy Group: A LongRange Electron-Withdrawing Substituent, Chem. Eur. J., 2002, 8 (4), 799 - 804 
113. Wipf P., Hopkins C. R., Efficient Synthesis of 1,4-Dihydro-2Hisoquinoline-3,5,8-triones via Cyclobutene Ring Expansion, J. Org. Chem., 1999, $64,6881-6887$

114. Miyamotoa Y., Kalisiakb J., Korthalsb K. et al., Expanded therapeutic potential in activity space of next-generation 5-nitroimidazole antimicrobials with broad structural diversity, PNAS, 2013, 110 (43), 17564-17569

115. Inam A., Siddiqui S. M., Macedo T. S., Moreira D. R., Leite A. C., Soares M. B., Azam A., Design, synthesis and biological evaluation of 3-[4-(7-chloroquinolin- 4-yl)-piperazin-1-yl]-propionic acid hydrazones as antiprotozoal agents, Eur. J. Med. Chem., 2014, 75, 67 - 76

116. Andrews S., Burgess S. J., Skaalrud D., Kelly J. X., Peyton D. H., Reversal Agent and Linker Variants of Reversed Chloroquines: Activities against Plasmodium falciparum, J. Med. Chem., 2010, 53, 916 - 919

117. Khairul M. F., Min T. H., Low J. H. Nasriyyah C. H. et al., Fluoxetine potentiates Chloroquine and Mefloquine effect on Multidrug-Resistant Plasmodium falciparum In Vitro, Jpn. J. Infect. Dis., 2006, 59, 329-331

118. Peer D., Dekel Y., Melikhov D., Margalit R., Fluoxetine Inhibits Multidrug Resistance Extrusion Pumps and Enhances Responses to Chemotherapy in Syngeneic and in Human Xenograft Mouse Tumor Models, Cancer Research, 2004, 64, 7562-7569

119. Peera D., Margalit R., Fluoxetine and reversal of multidrug resistance, Cancer Letters, 2006, 237, $180-187$ 


\section{APPENDICES}

\section{Appendix A: List of Intermediate Compounds Synthesized}

(PL16. No.




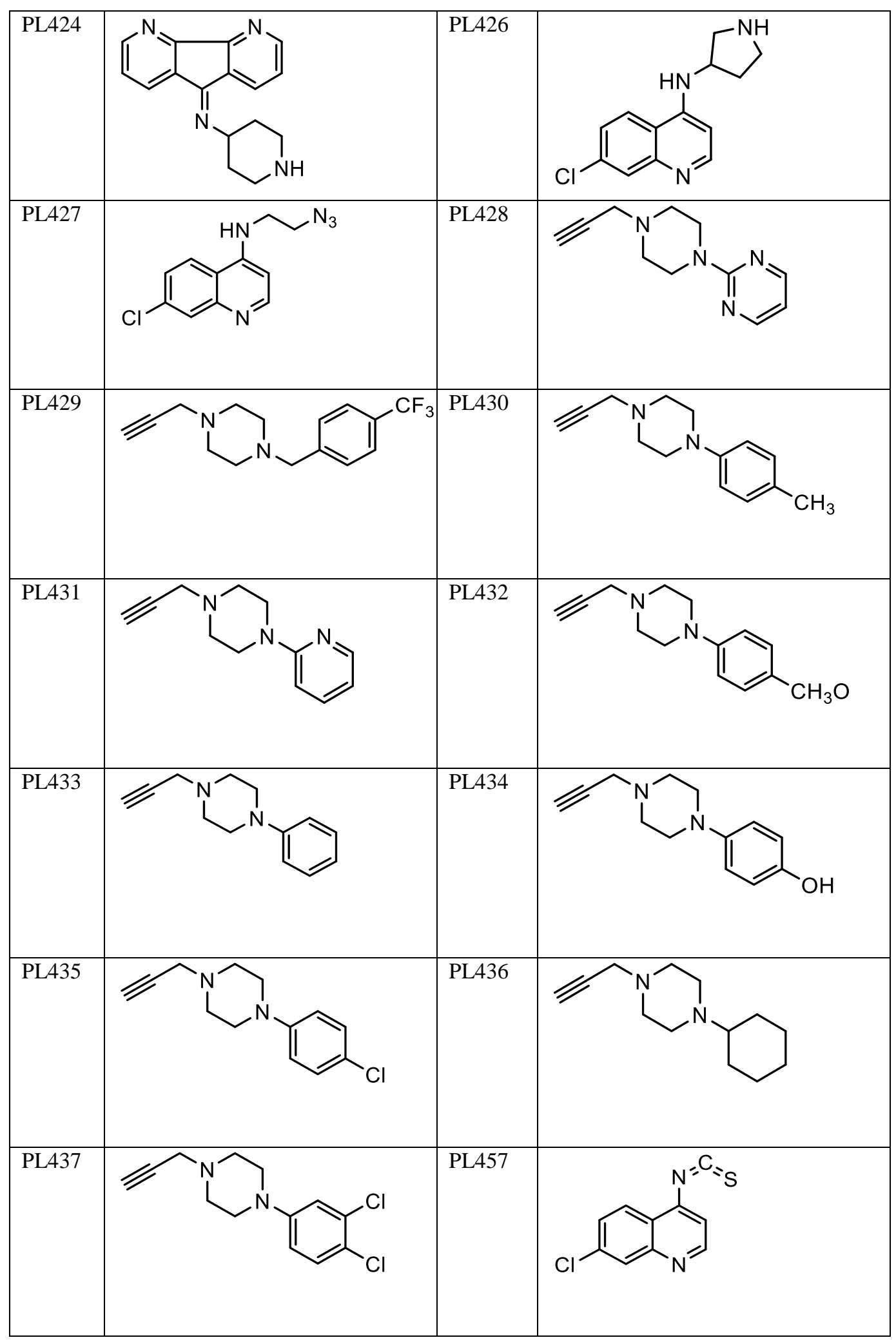




PL460


Appendix B: List of Target Compounds Synthesized

\begin{tabular}{|c|c|c|c|c|c|c|}
\hline $\begin{array}{l}\text { PL } \\
\text { No. }\end{array}$ & Click Compound & $\begin{array}{l}\mathrm{IC}_{50} \\
(\mathrm{D6}, \\
\mathrm{Dd} 2, \\
\text { 7G8) }\end{array}$ & $\begin{array}{l}\mathrm{HBD} / \\
\mathrm{HBA}\end{array}$ & NRot & CLogP & Mol.Wt \\
\hline $\mathrm{CQ}$ & & $\begin{array}{l}5.9 \\
54 \\
57\end{array}$ & $1 / 3$ & 8 & 4.75 & 305.85 \\
\hline 369 & & $\begin{array}{l}>250 \\
>250 \\
>250\end{array}$ & $1 / 5$ & 8 & 5.63 & 450.59 \\
\hline 370 & & $\begin{array}{l}>250 \\
>250 \\
>250\end{array}$ & $1 / 4$ & 8 & 6.37 & 436.60 \\
\hline 403 & & $\begin{array}{l}10.4 \\
12.8 \\
14.5\end{array}$ & $1 / 6$ & 8 & 6.28 & 447.85 \\
\hline 404 & & $\begin{array}{l}25 \\
81.6 \\
48\end{array}$ & $2 / 6$ & 8 & 4.84 & 469.97 \\
\hline 405 & & $\begin{array}{l}98.6 \\
210 \\
192\end{array}$ & $1 / 6$ & 7 & 4.61 & 393.88 \\
\hline
\end{tabular}




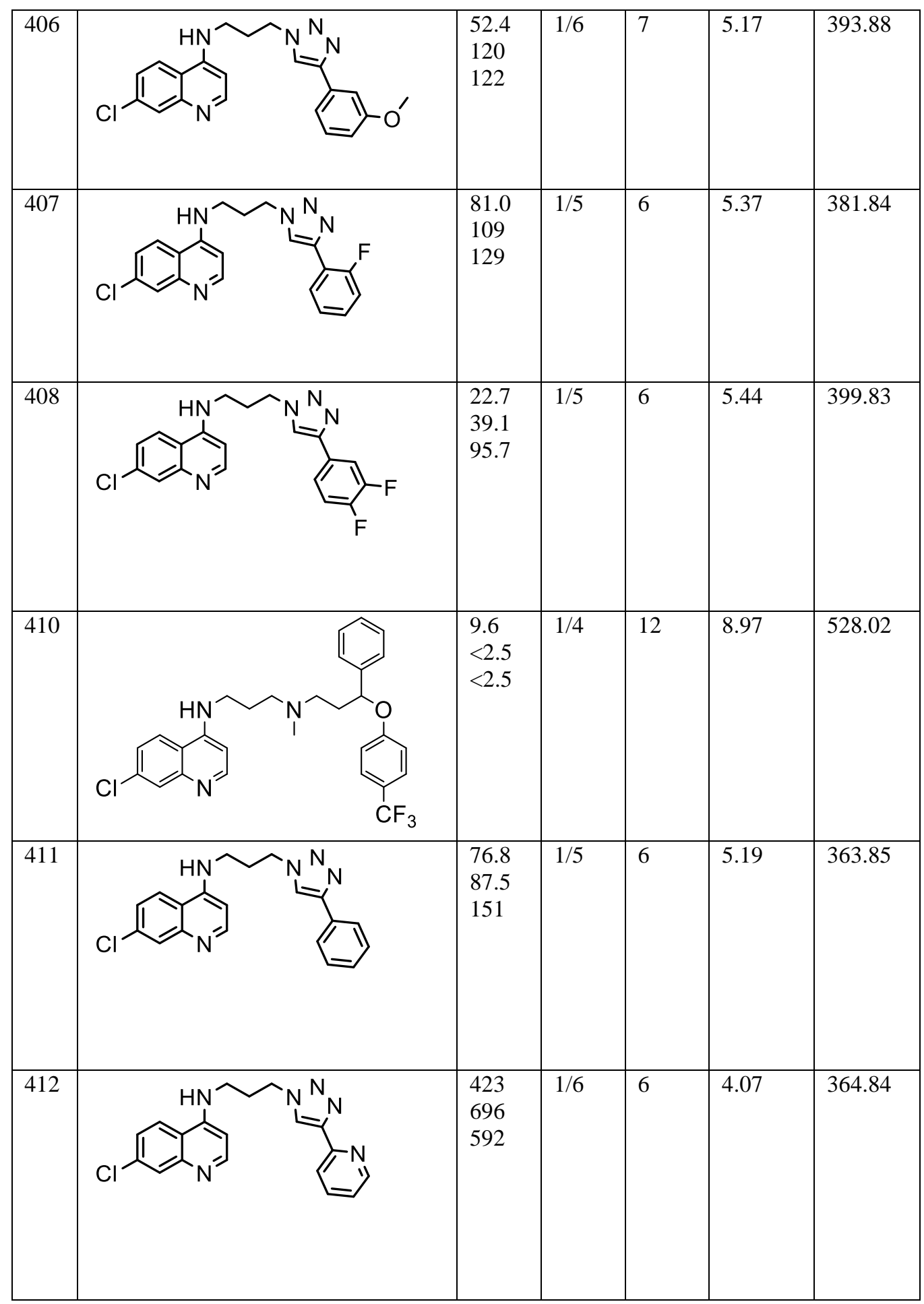




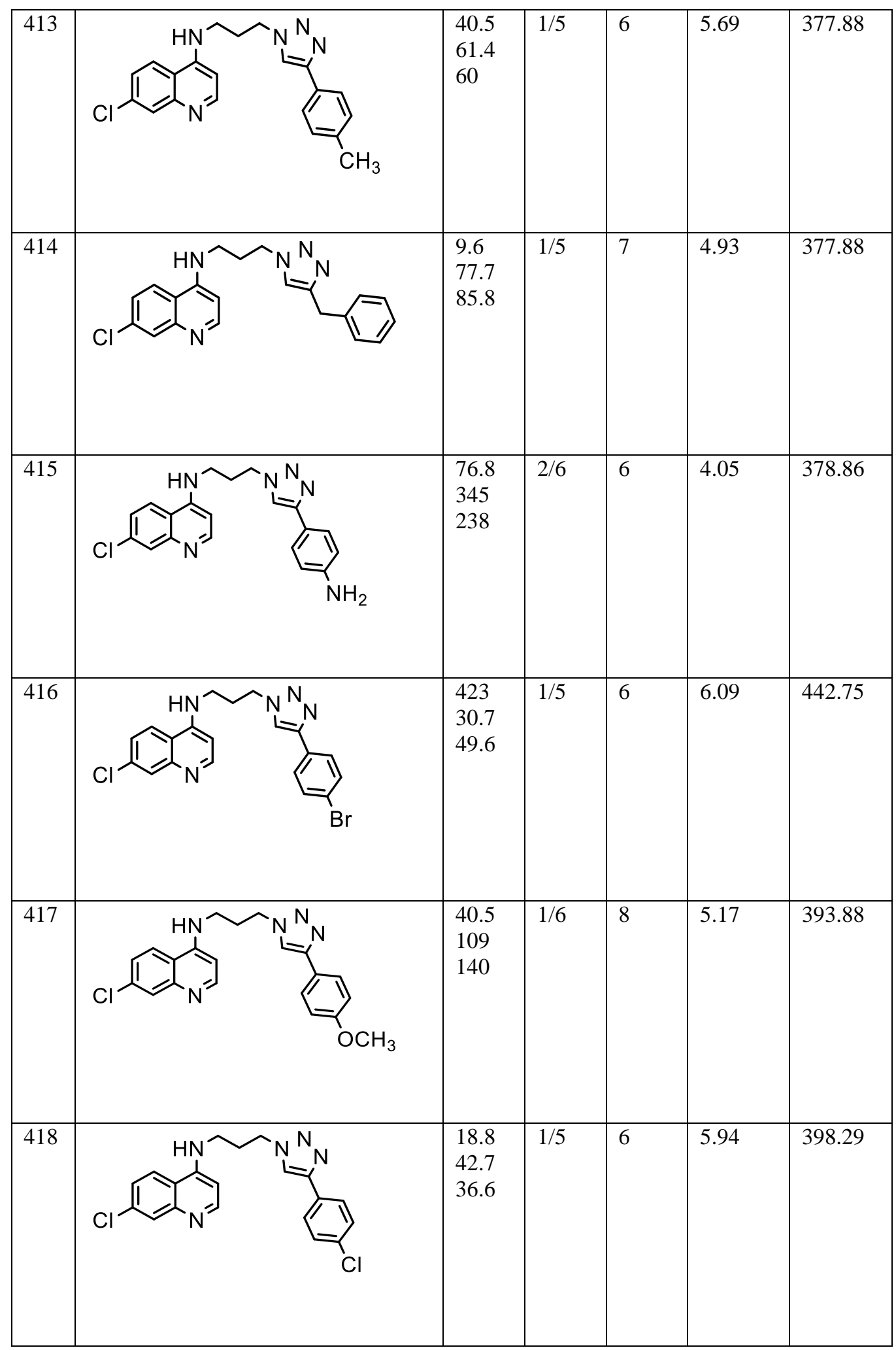




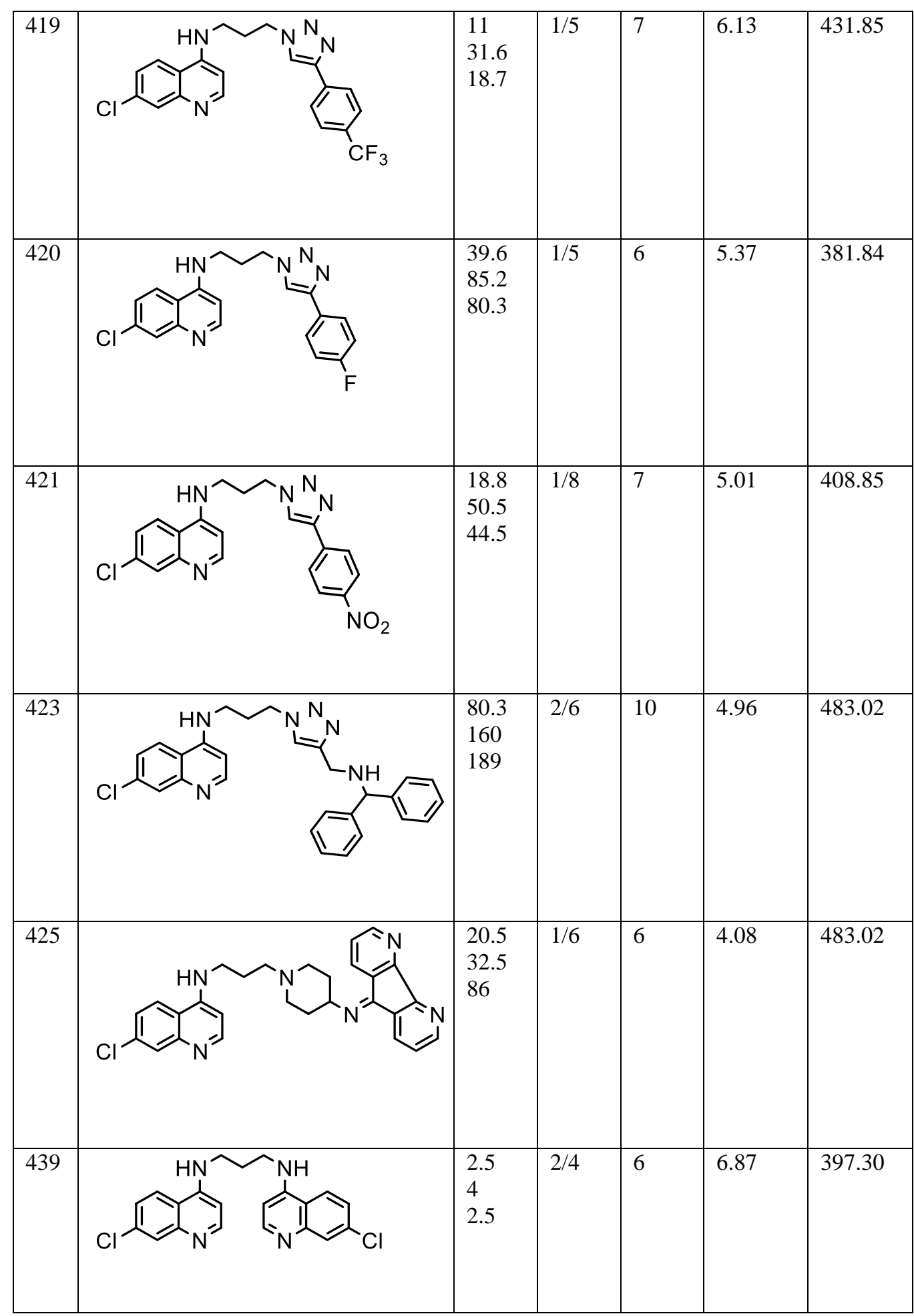




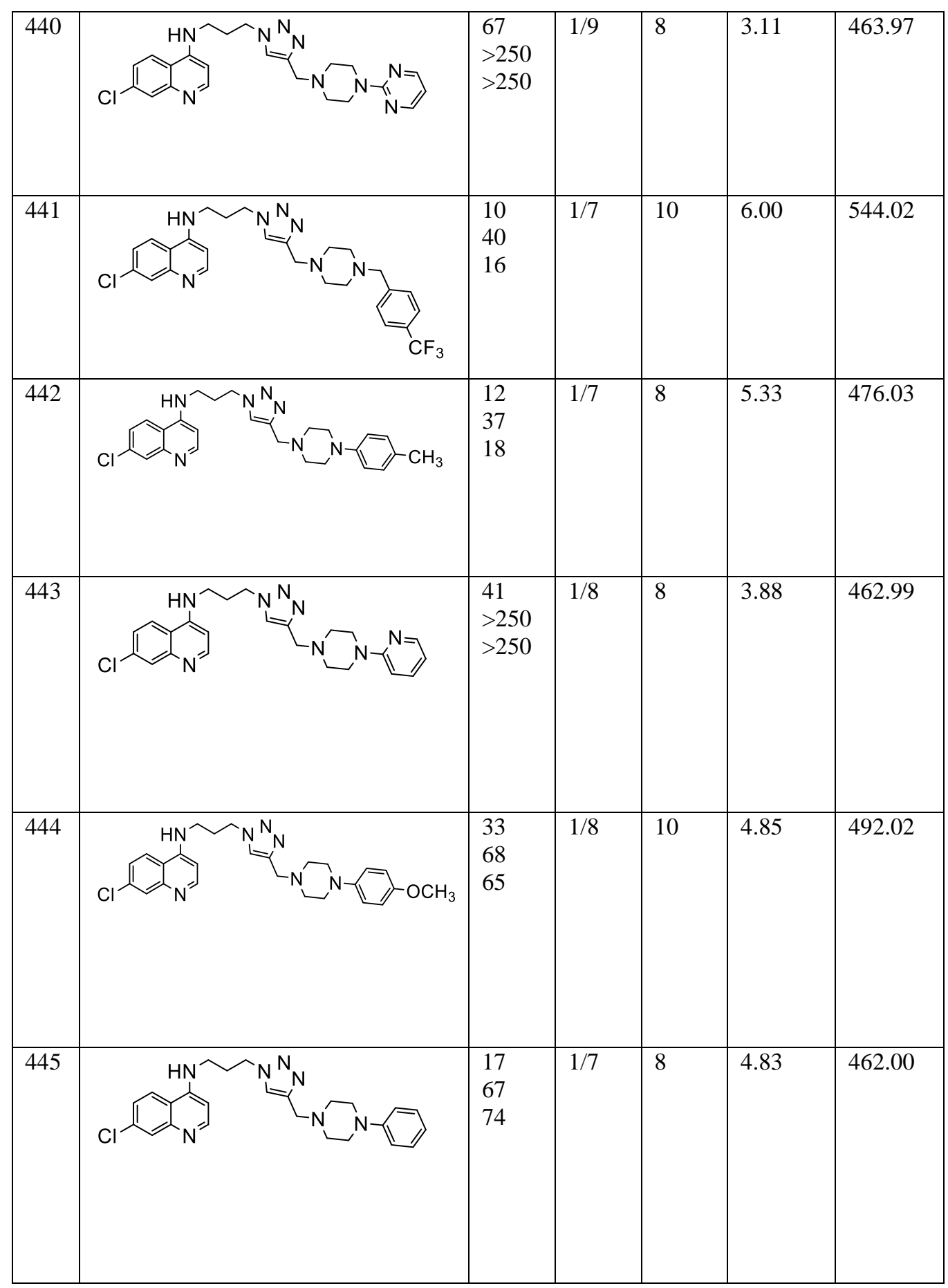




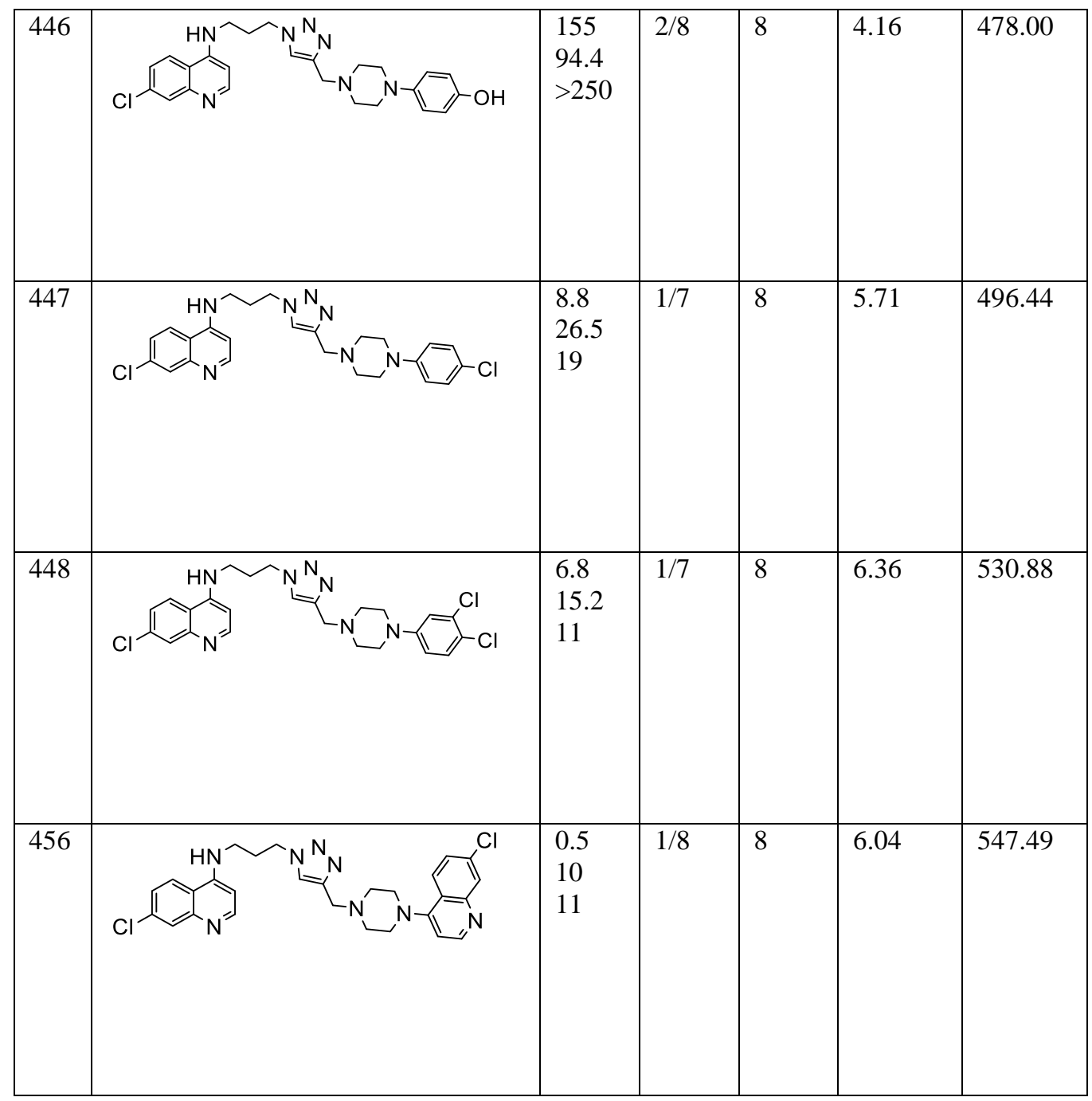




\section{Appendix C: Selected Spectral and Chromatography Data}

${ }^{1}$ H-Proton spectroscopy, COSY, HSQC, HMBC, NOESY, ${ }^{13} \mathrm{C}$-Spectroscopy, mass spectroscopy and combiflash chromatography data of selected compounds:<smiles>FC(F)(F)Oc1ccc(-c2cn(CCCNc3ccnc4cc(Cl)ccc34)nn2)cc1</smiles>

PL403<smiles>CN(CCCNc1ccnc2cc(Cl)ccc12)CCC(Oc1ccc(C(F)(F)F)cc1)c1ccccc1</smiles>

PL410<smiles>Clc1ccc2c(NCCCn3cc(CN4CCN(c5ccc(Cl)c(Cl)c5)CC4)nn3)ccnc2c1</smiles>

PL448<smiles>Clc1ccc2c(NCCCn3cc(CN4CCN(c5ccnc6cc(Cl)ccc56)CC4)nn3)ccnc2c1</smiles>

PL456 


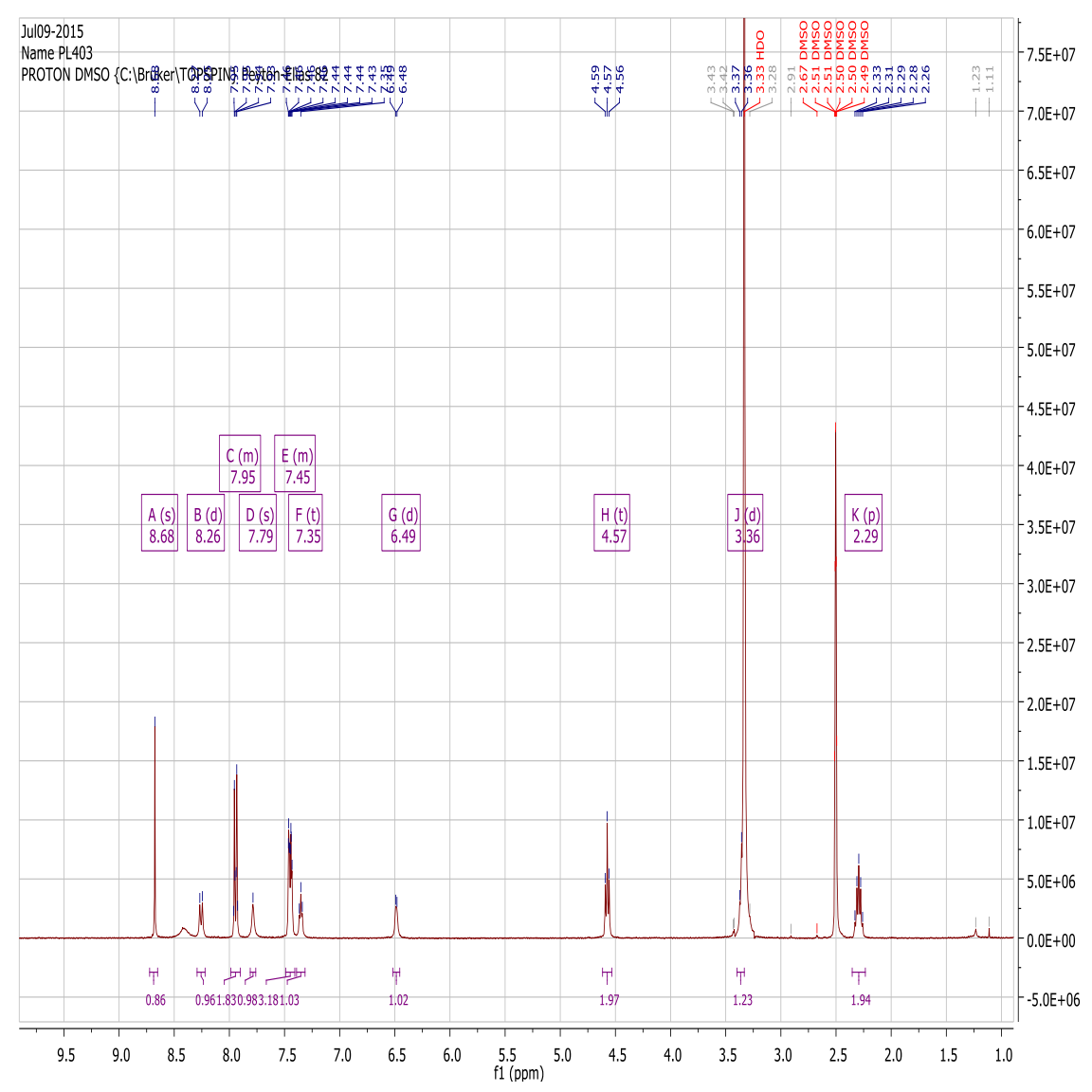

Figure 1.1. ${ }^{1} \mathrm{H}$-proton spectrum of PL403 


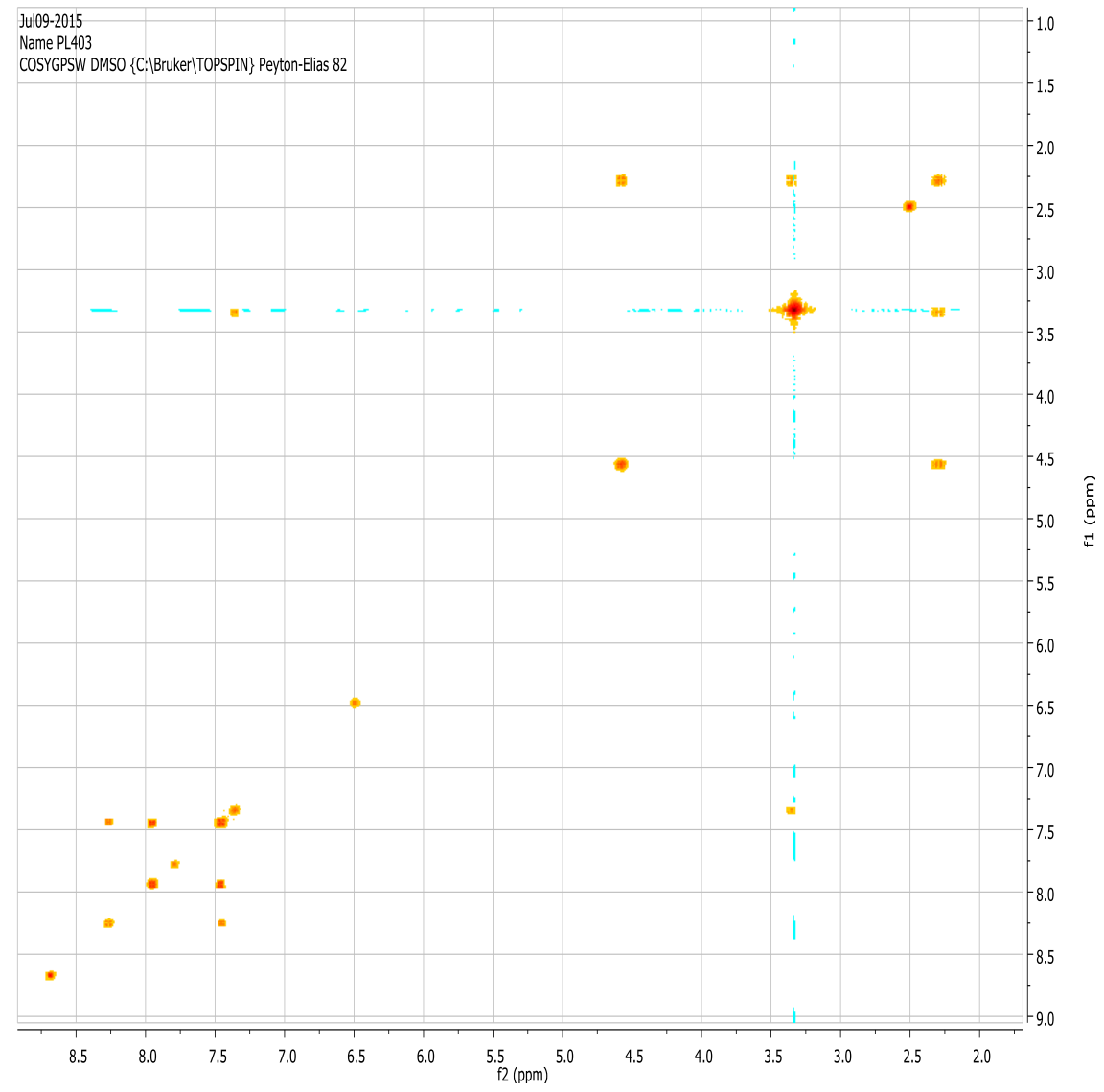

Figure 1.2. COSY spectrum of PL403 


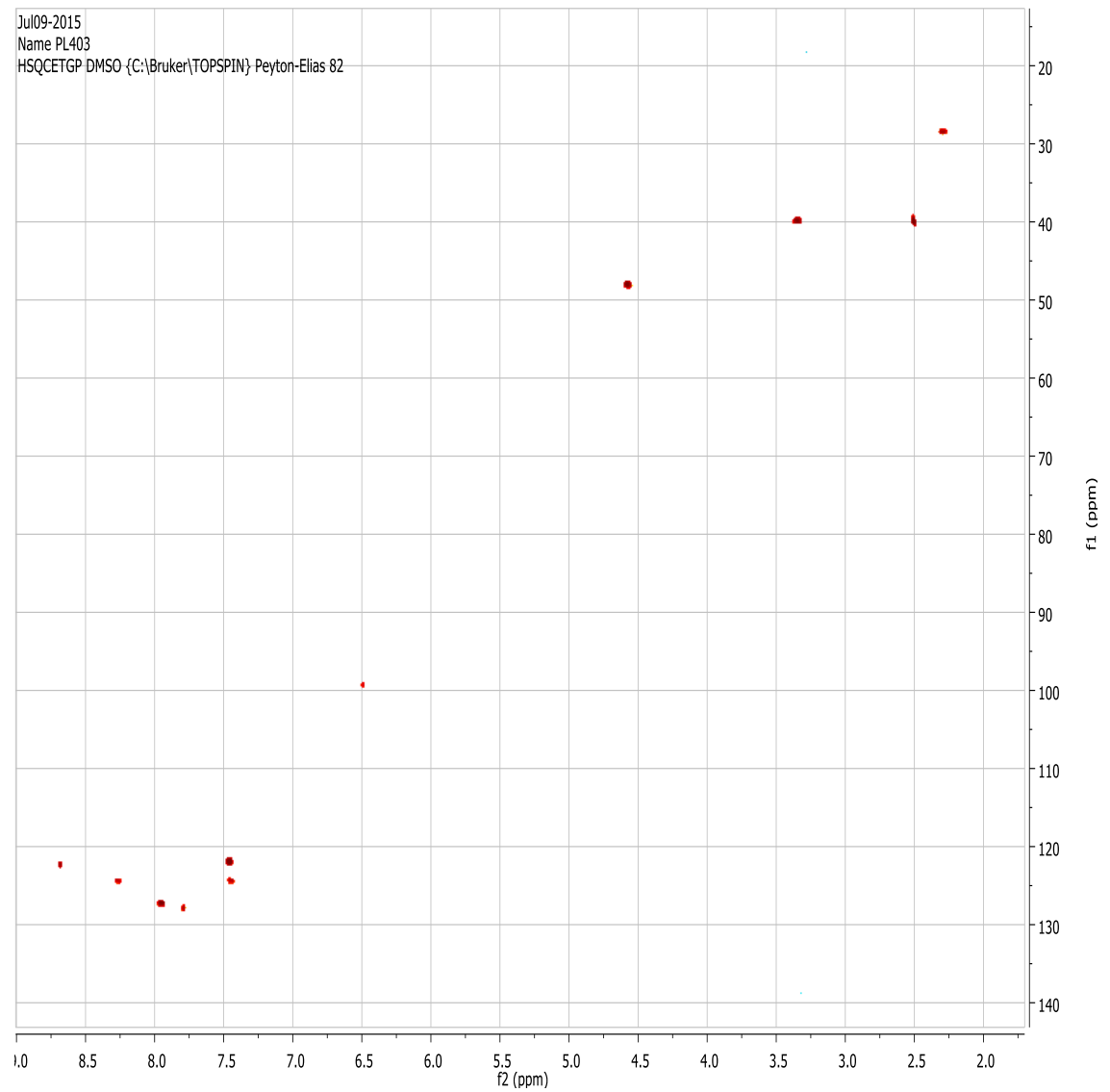

Figure 1.3. HSQC spectrum of PL403 


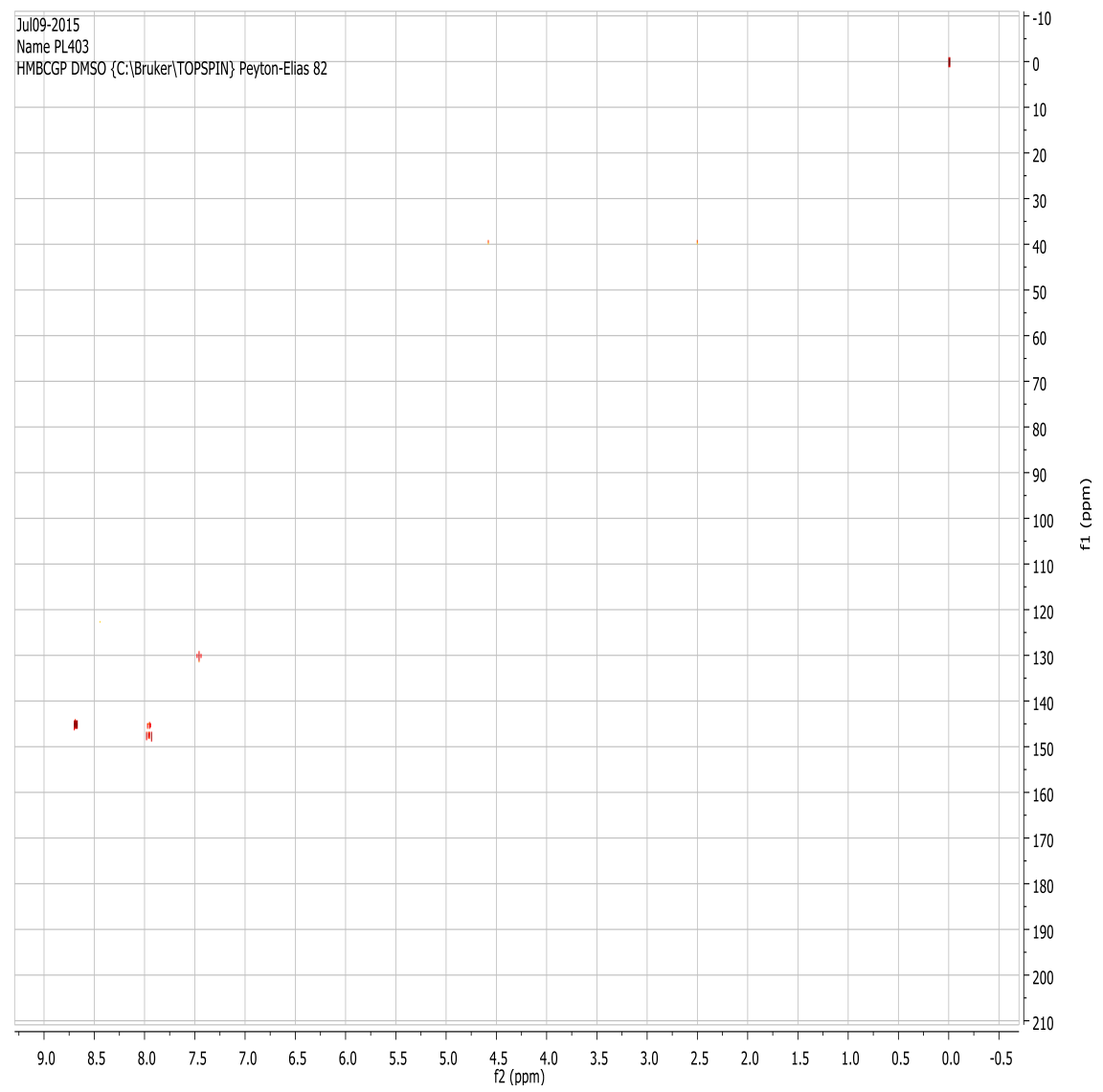

Figure 1.4. HMBC spectrum of PL403 


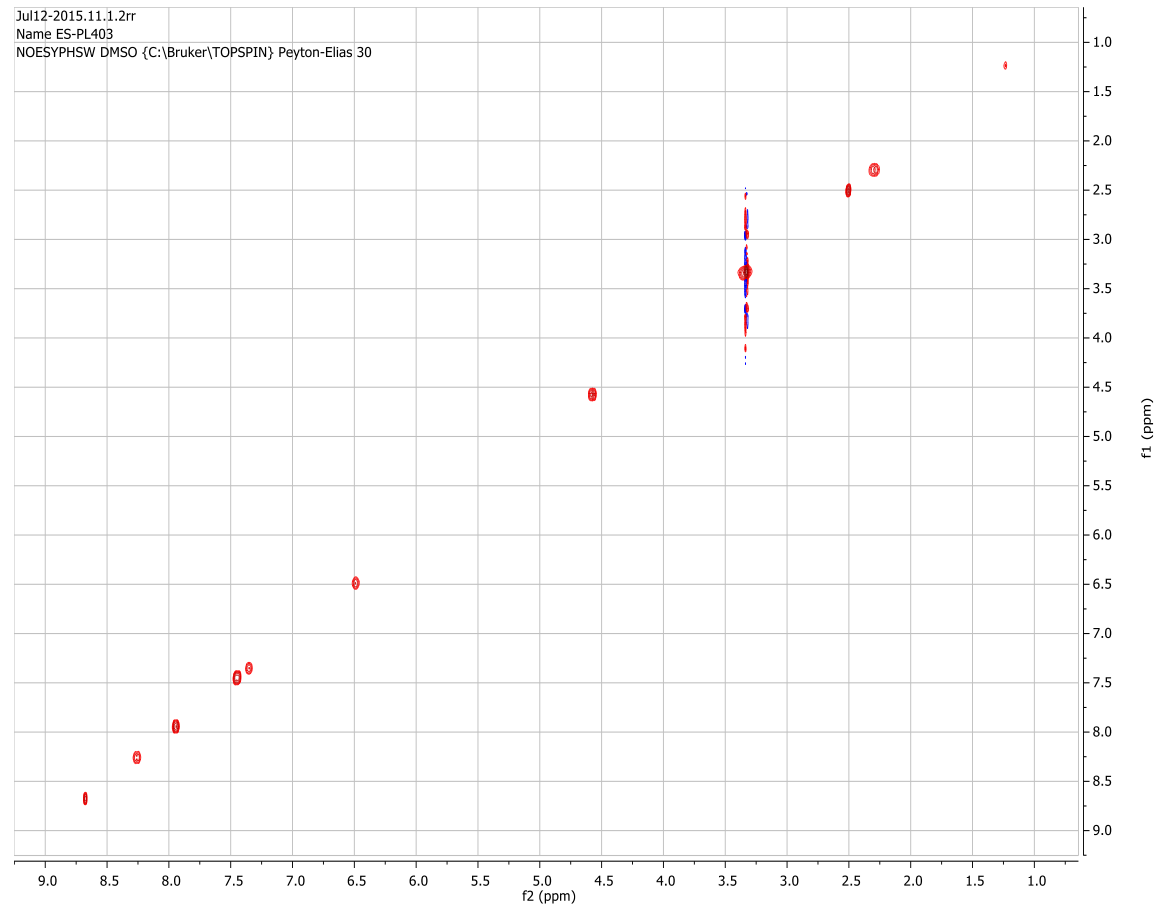

Figure 1.5. NOESY spectrum of PL403 


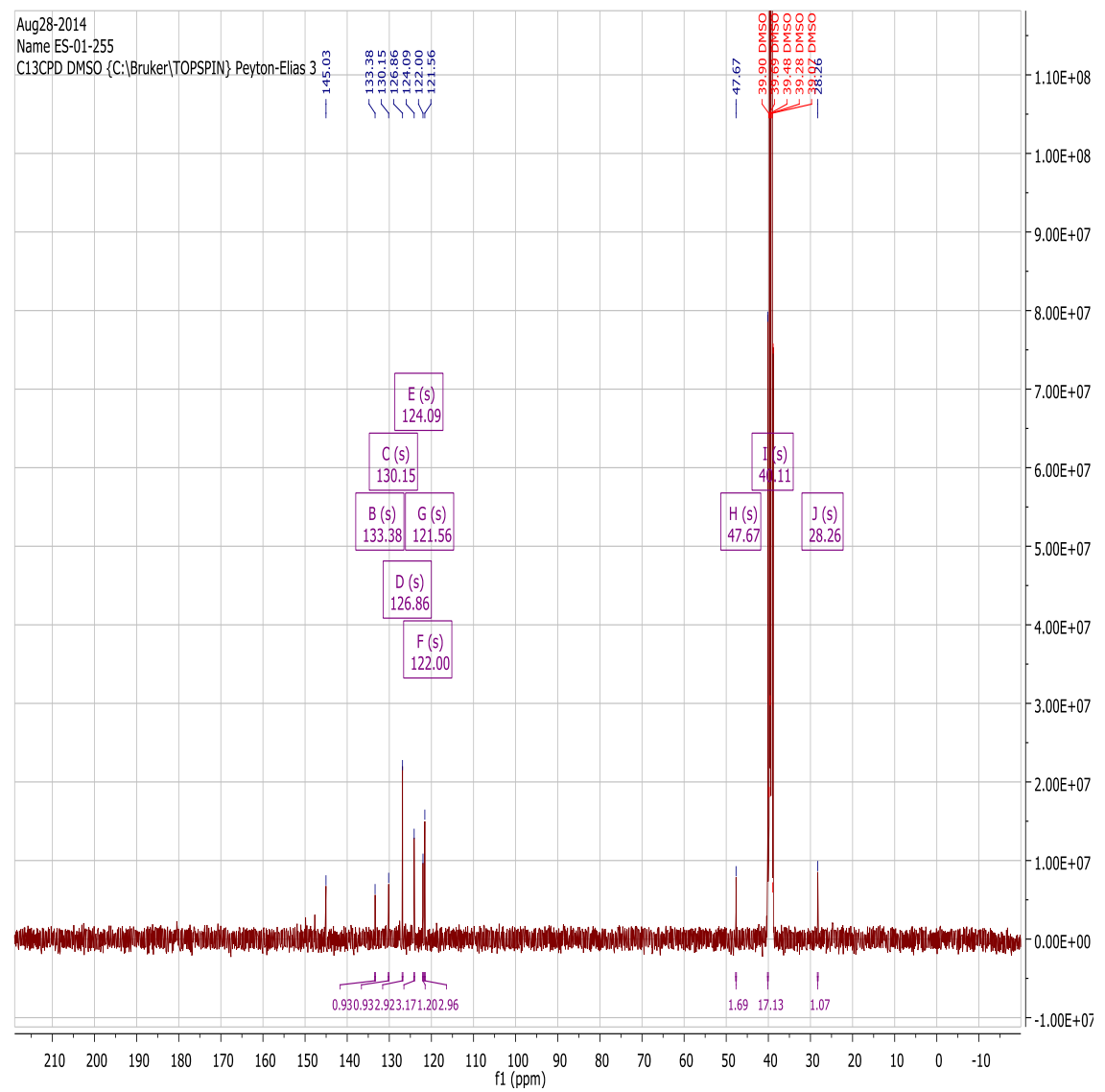

Figure 1.6. ${ }^{13} \mathrm{C}$-spectrum of PL403 


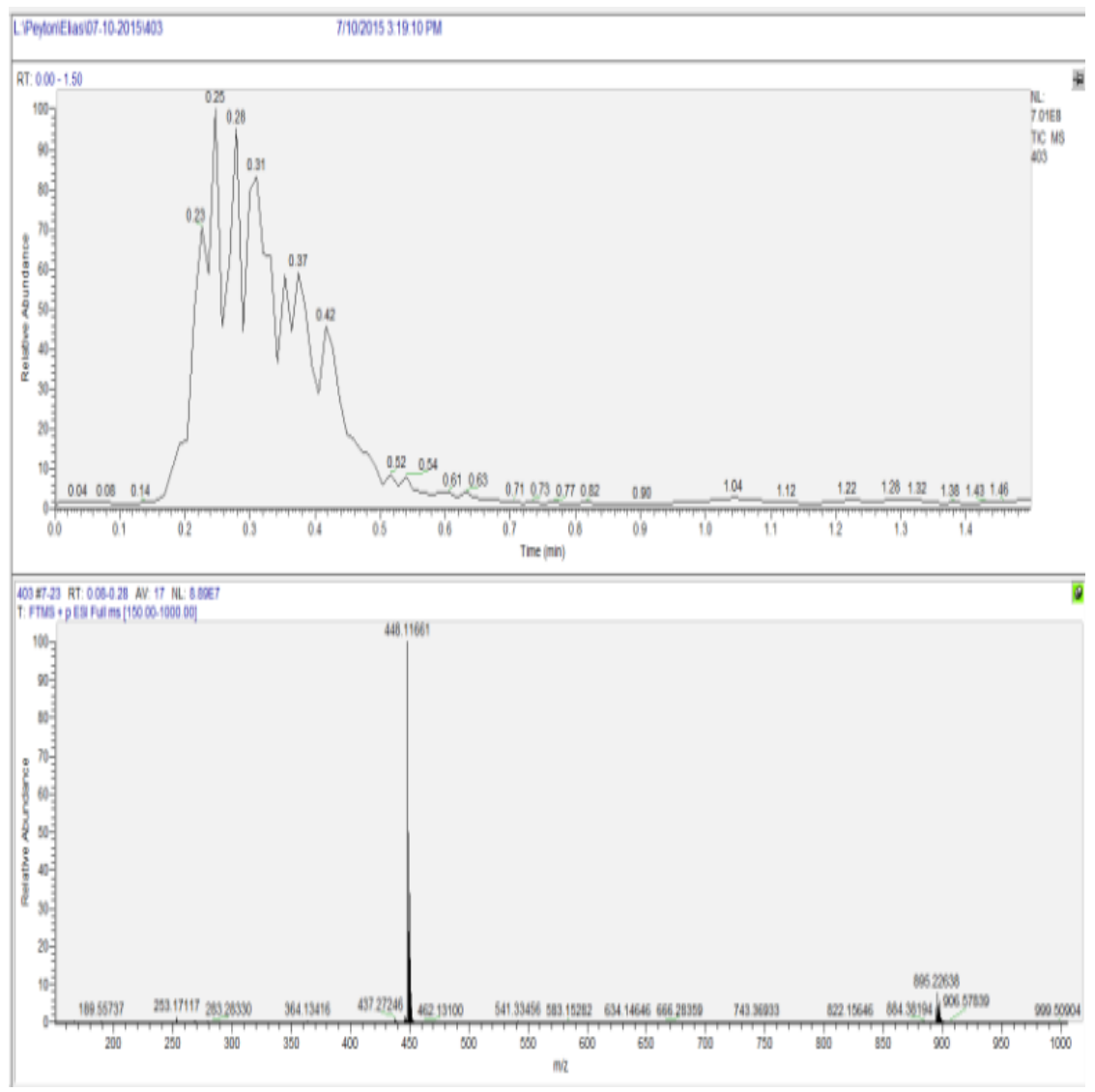

Figure 1.7. Mass spectrum of PL403 


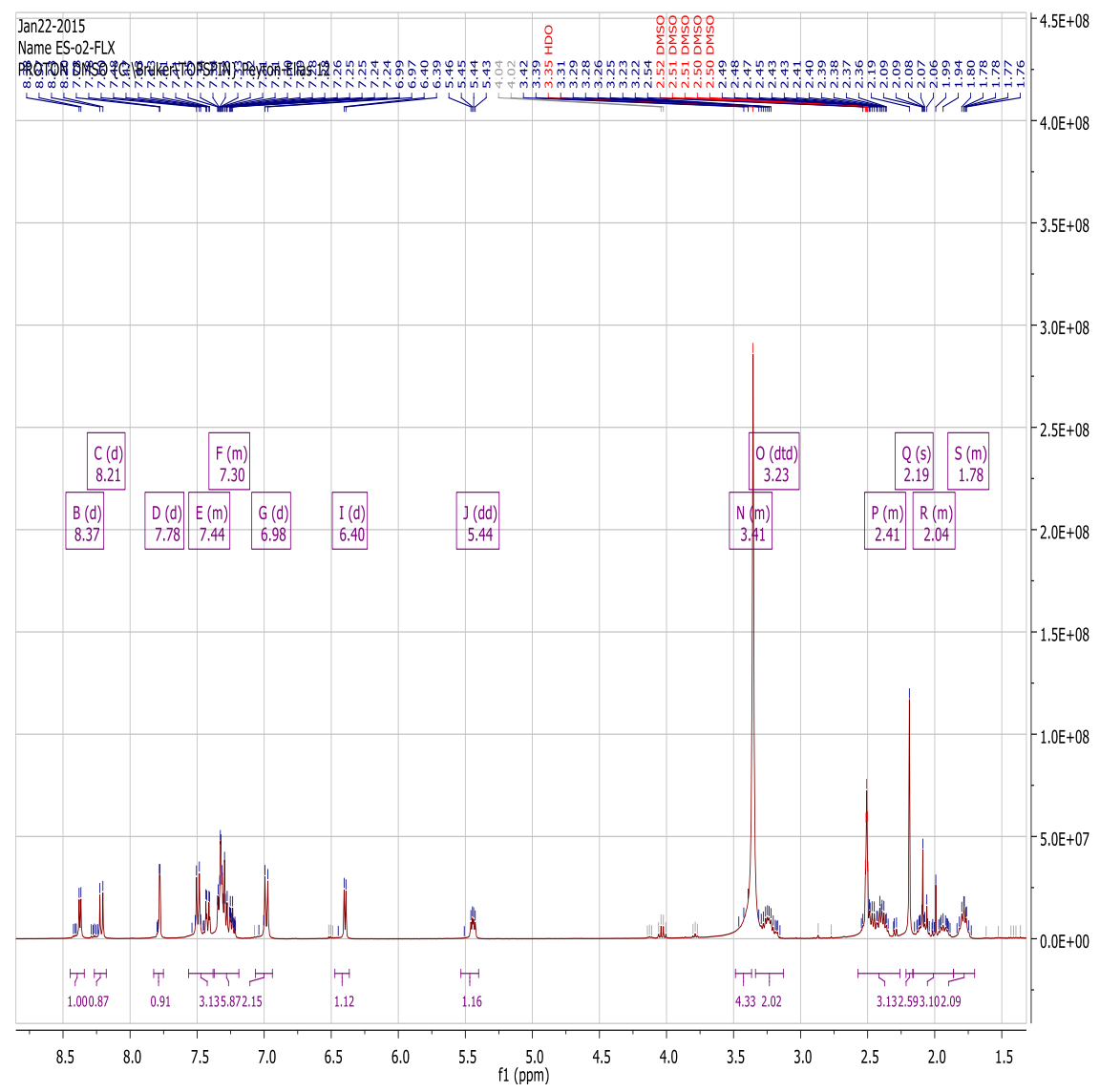

Figure 2.1. ${ }^{1} \mathrm{H}$-proton spectrum of PL410 


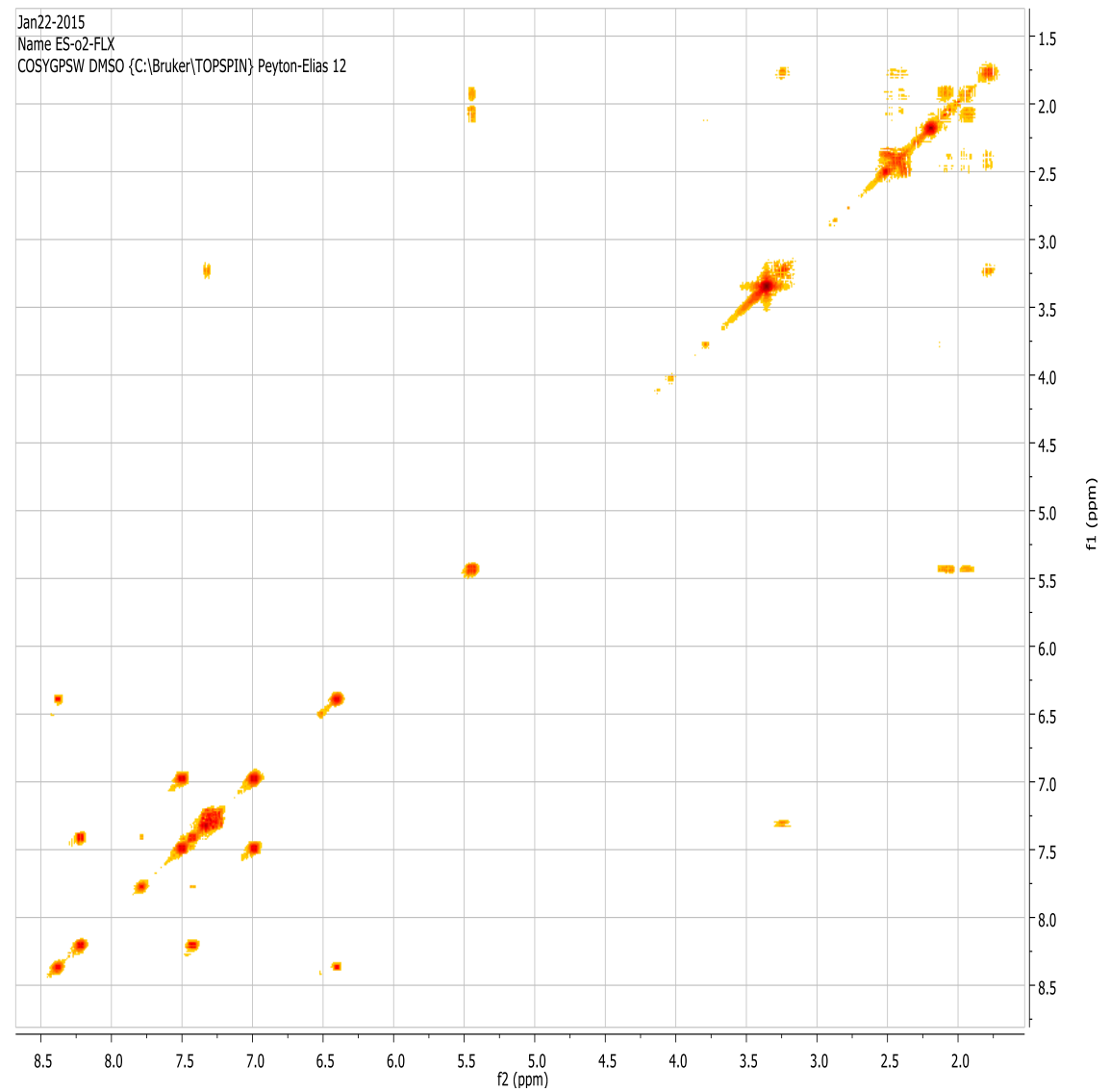

Figure 2.2. COSY spectrum of PL410 


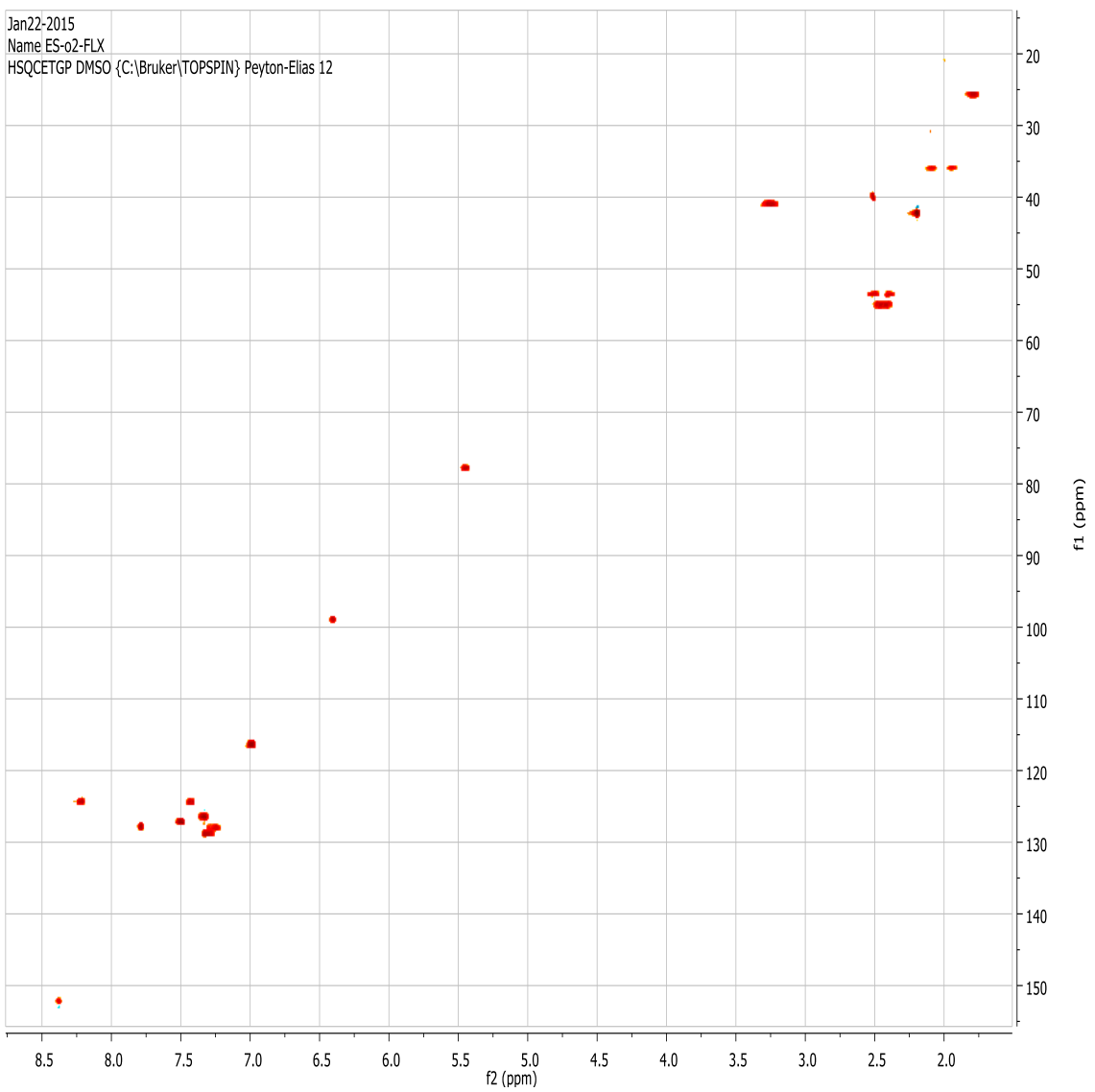

Figure 2.3. HSQC spectrum of PL410 


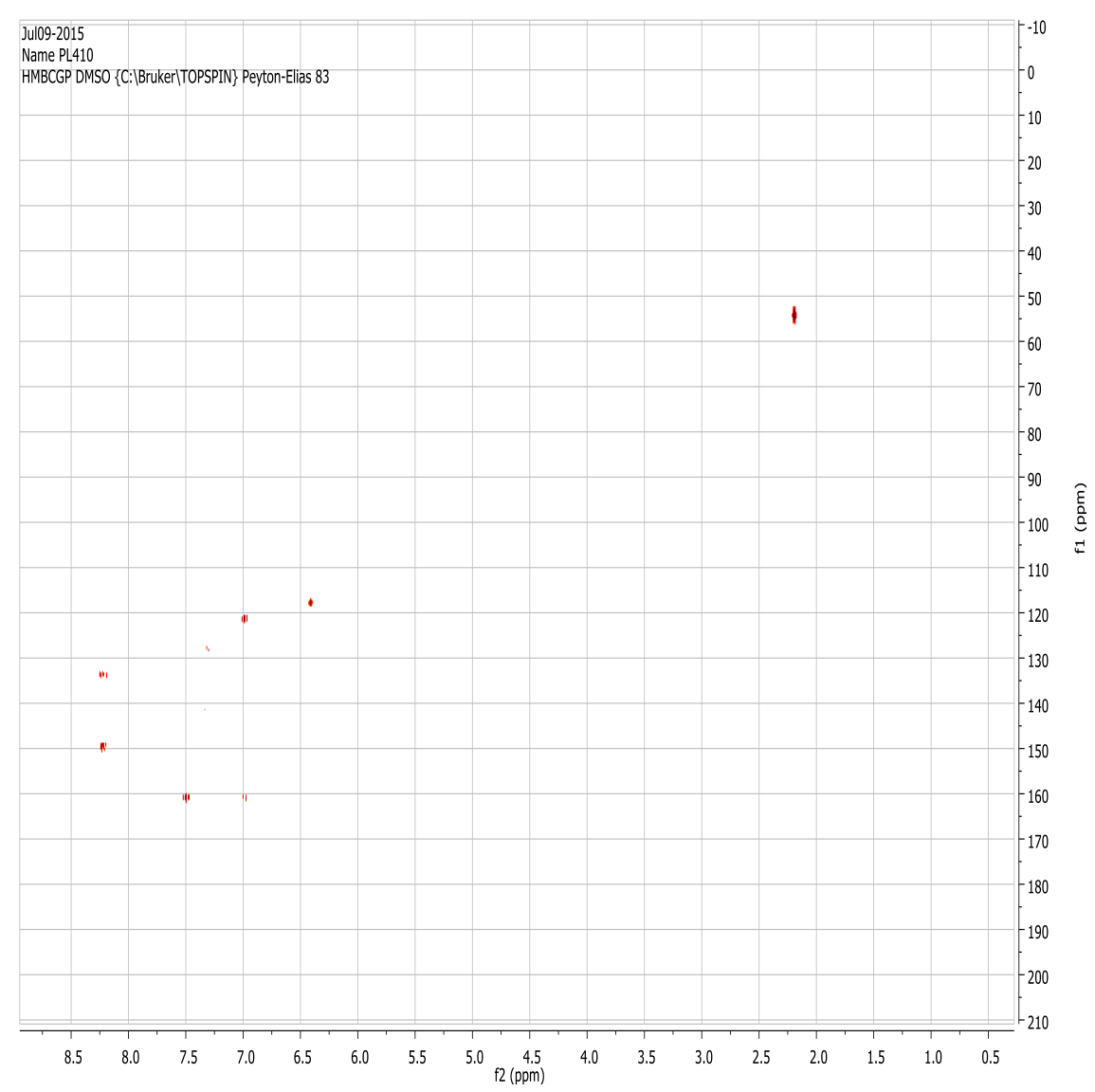

Figure 2.4. HMBC spectrum of PL410 


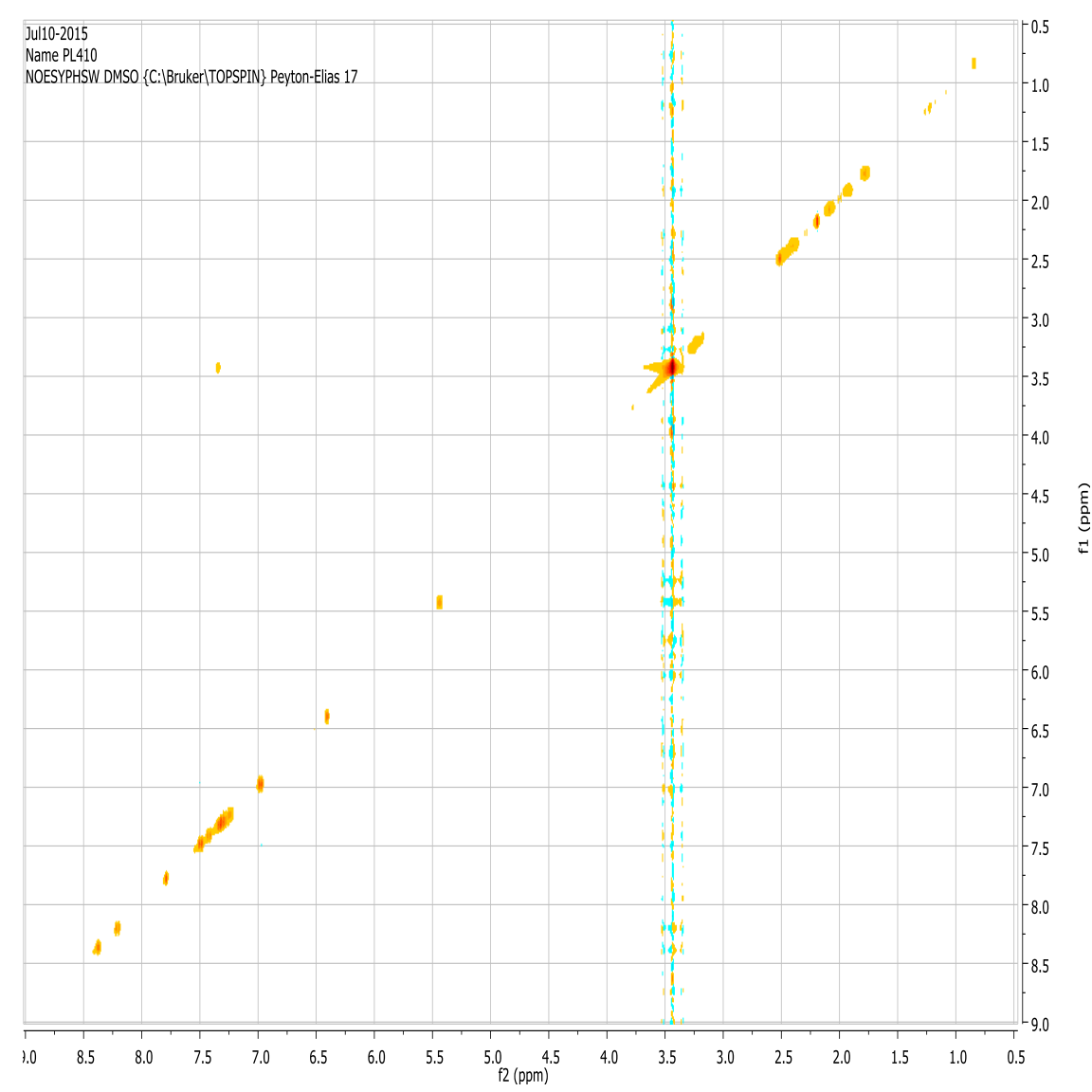

Figure 2.5. NOESY spectrum of PL410 


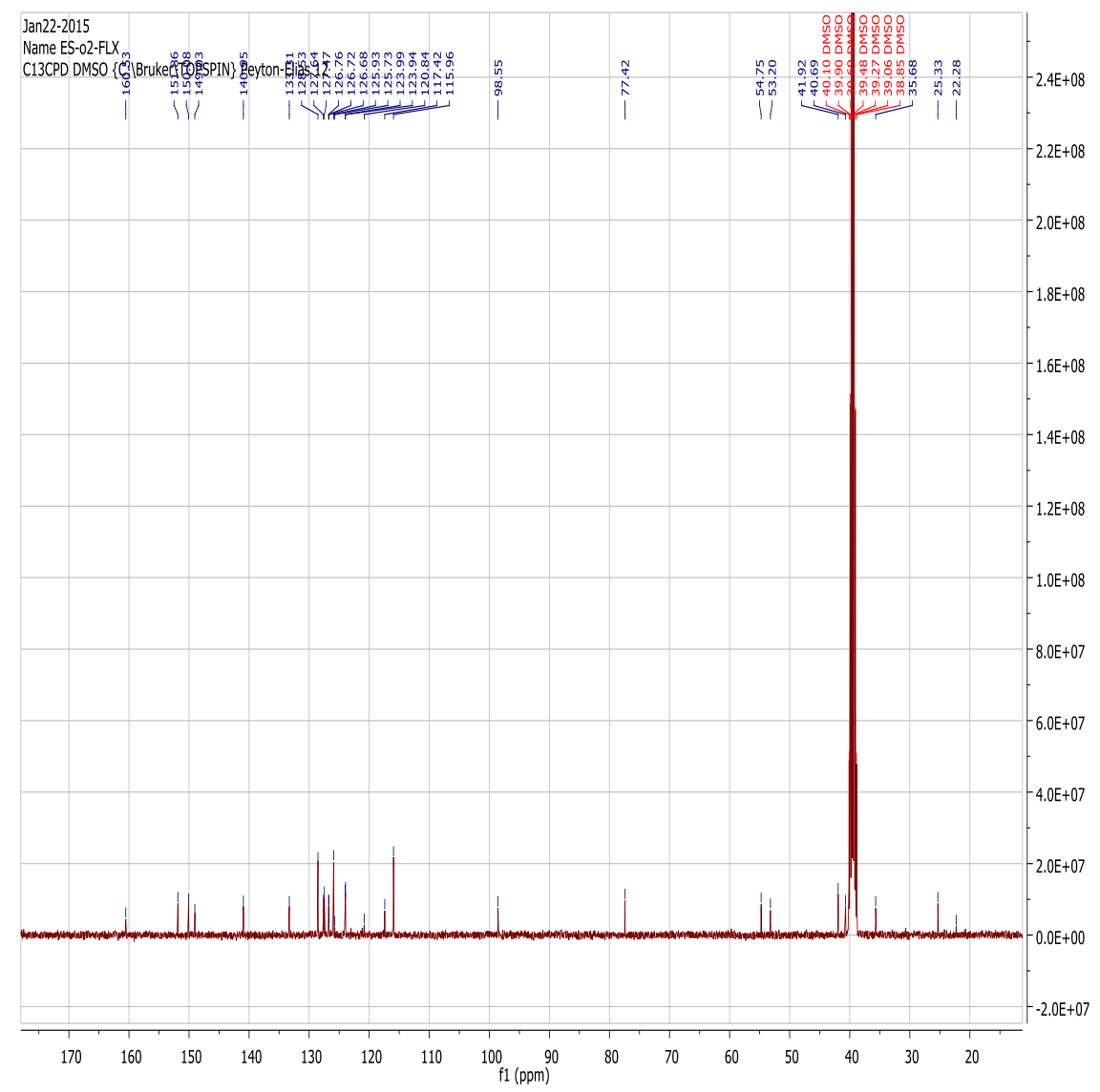

Figure 2.6. ${ }^{13} \mathrm{C}$-spectrum of PL410 


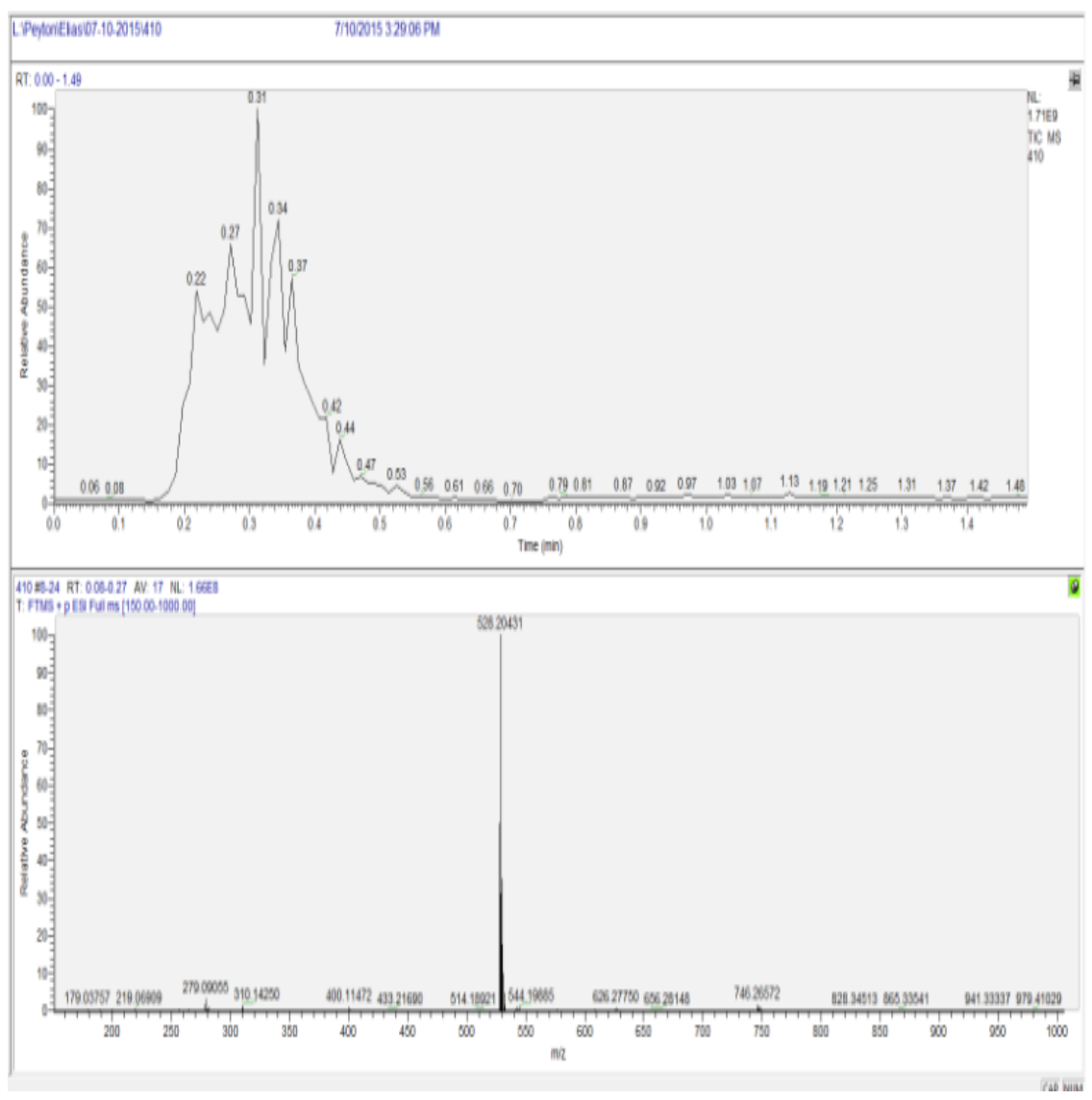

Figure 2.7. Mass spectrum of PL410 


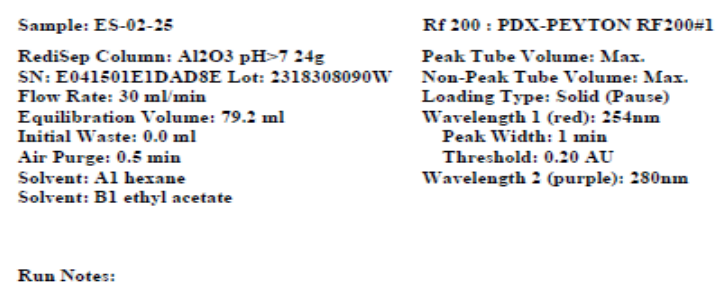

Run Notes:
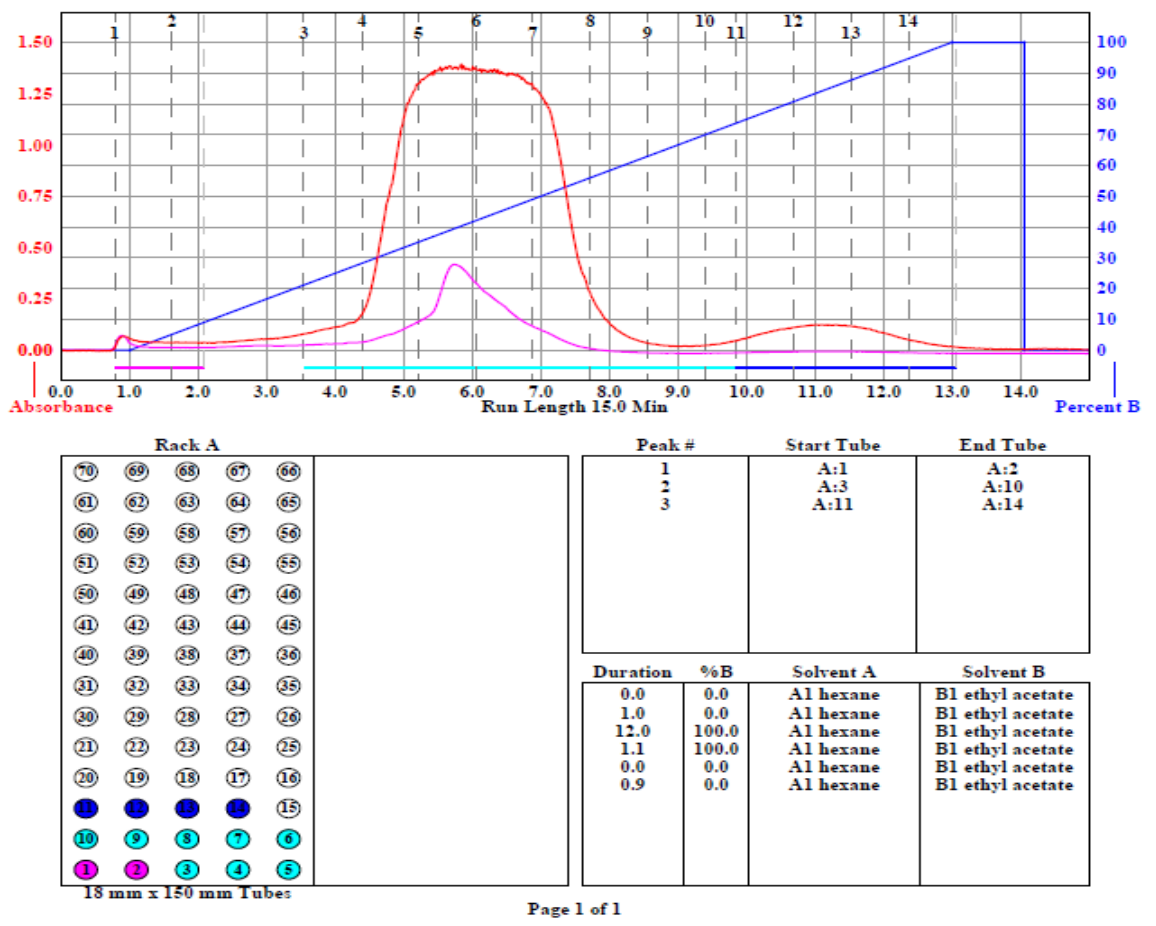

Figure 2.8. Combiflash chomatography of PL410 


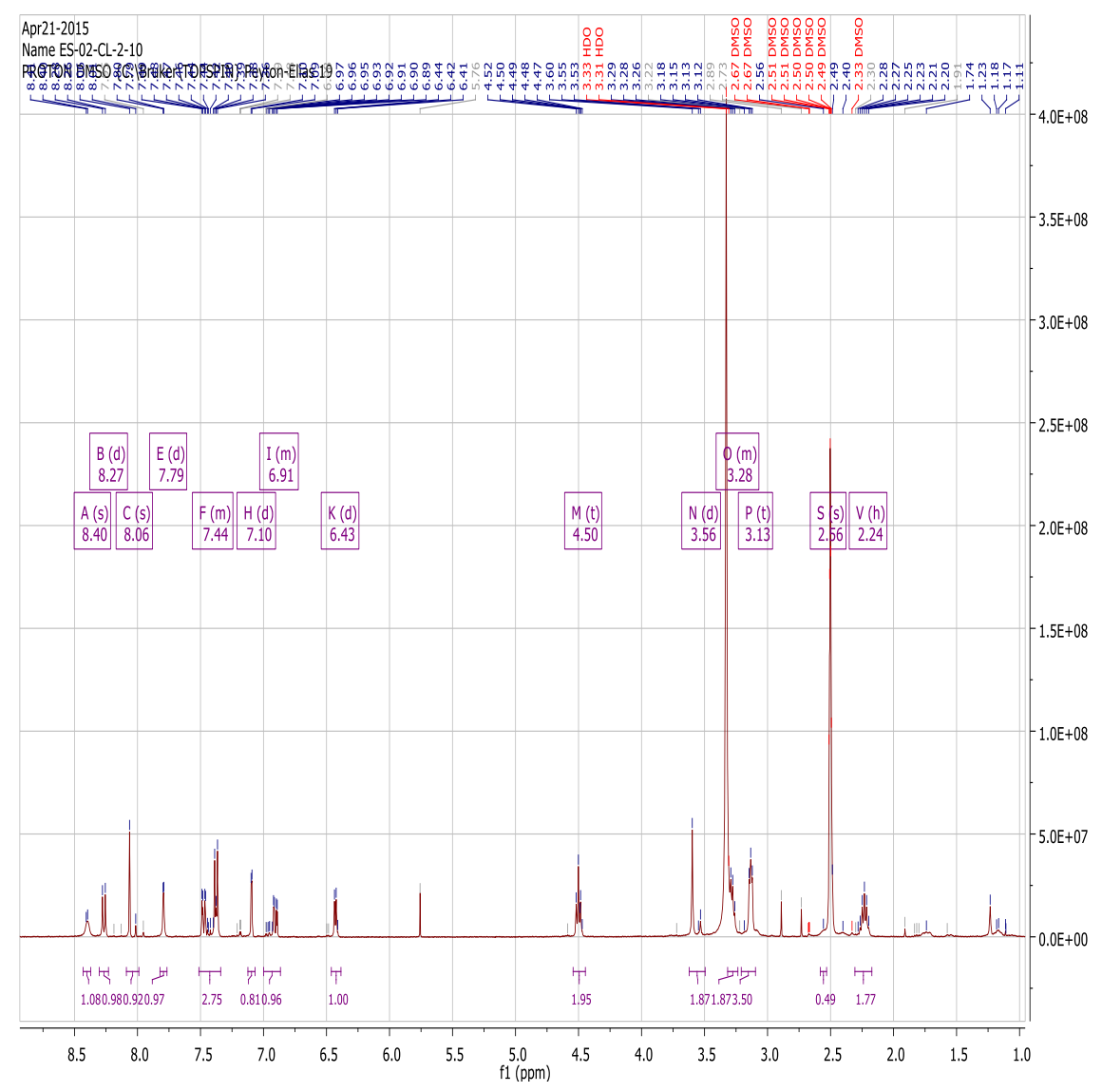

Figure 3.1. ${ }^{1} \mathrm{H}$-proton spectrum of PL448 


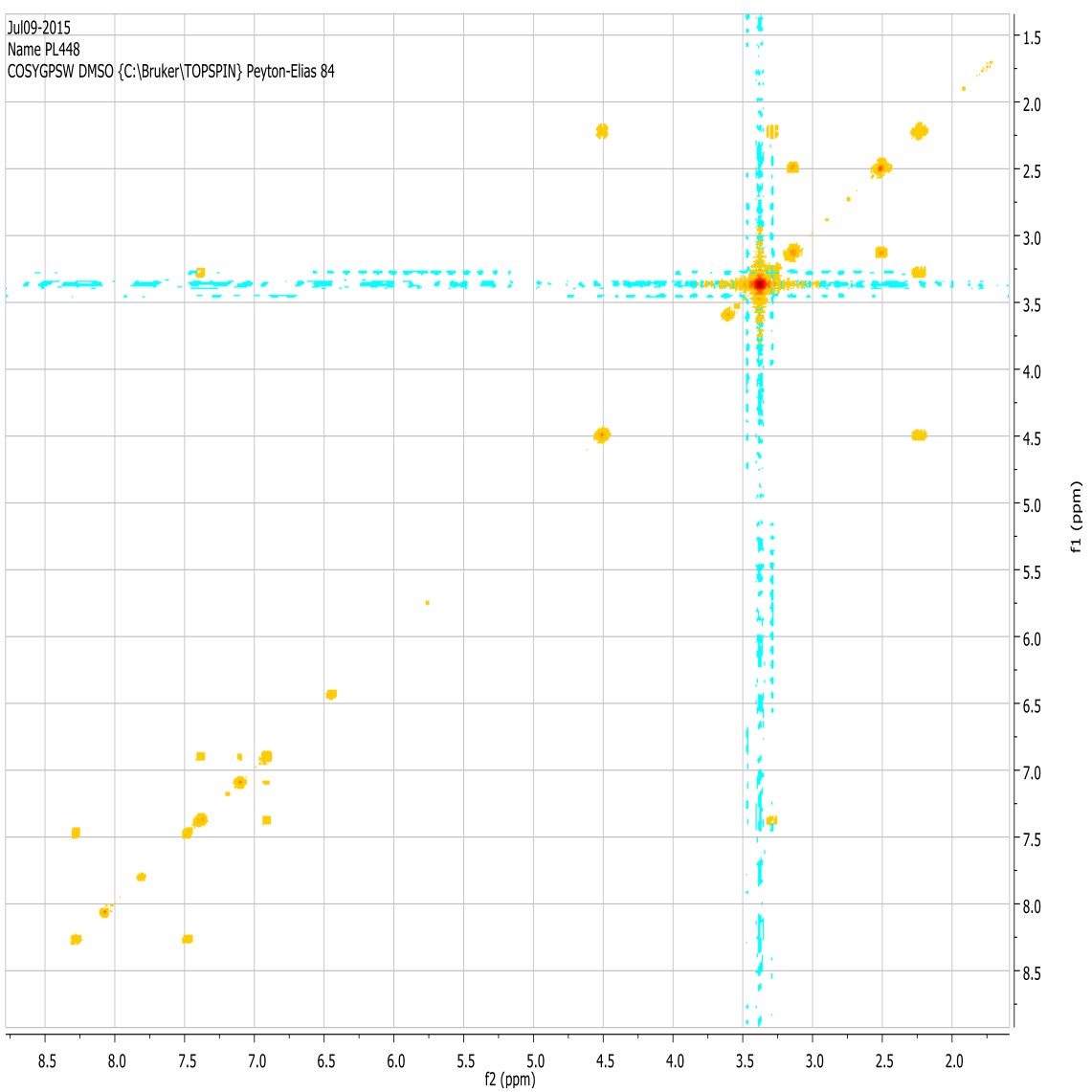

Figure 3.2. COSY spectrum of PL448 


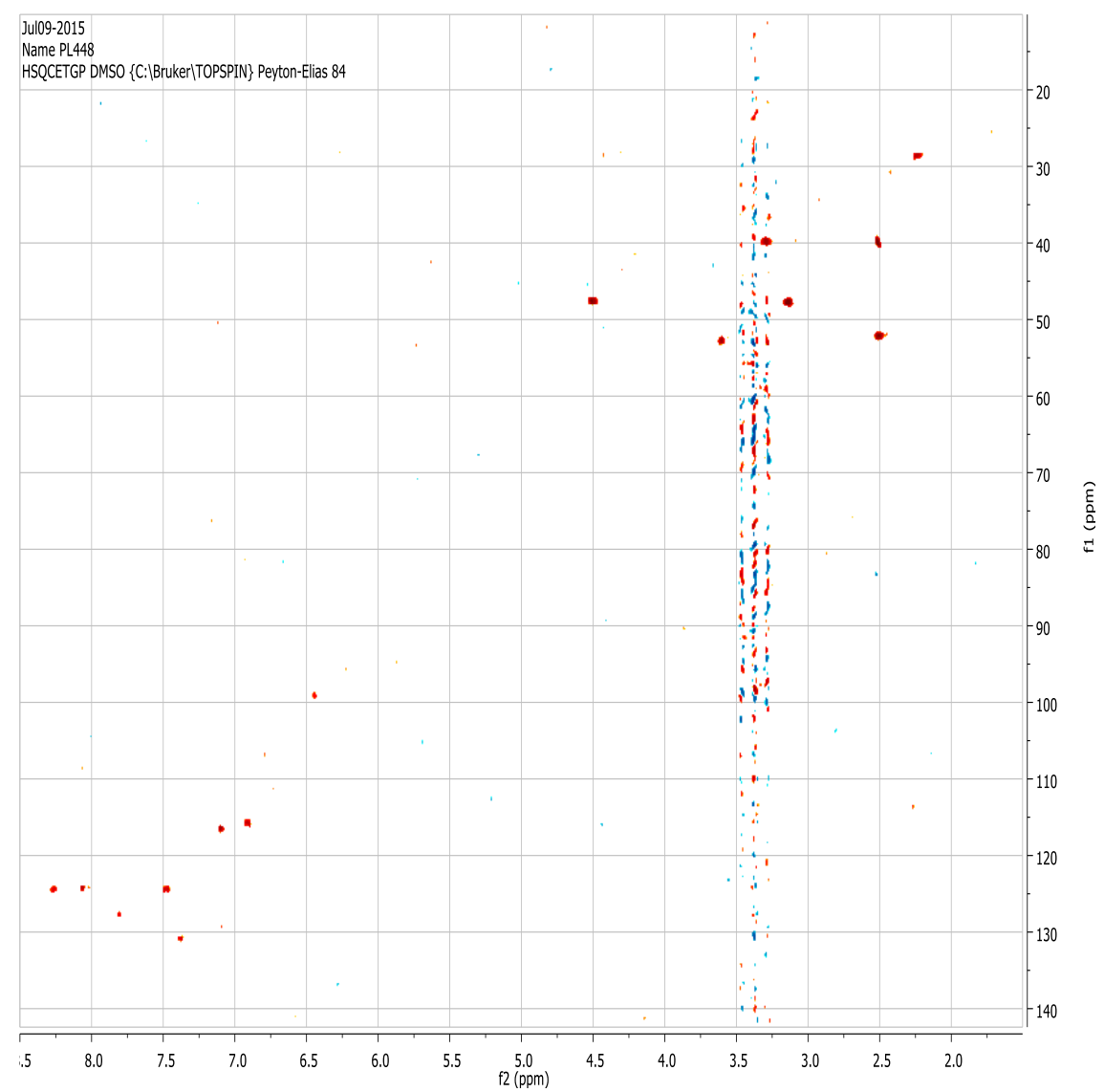

Figure 3.3. HSQC spectrum of PL448 


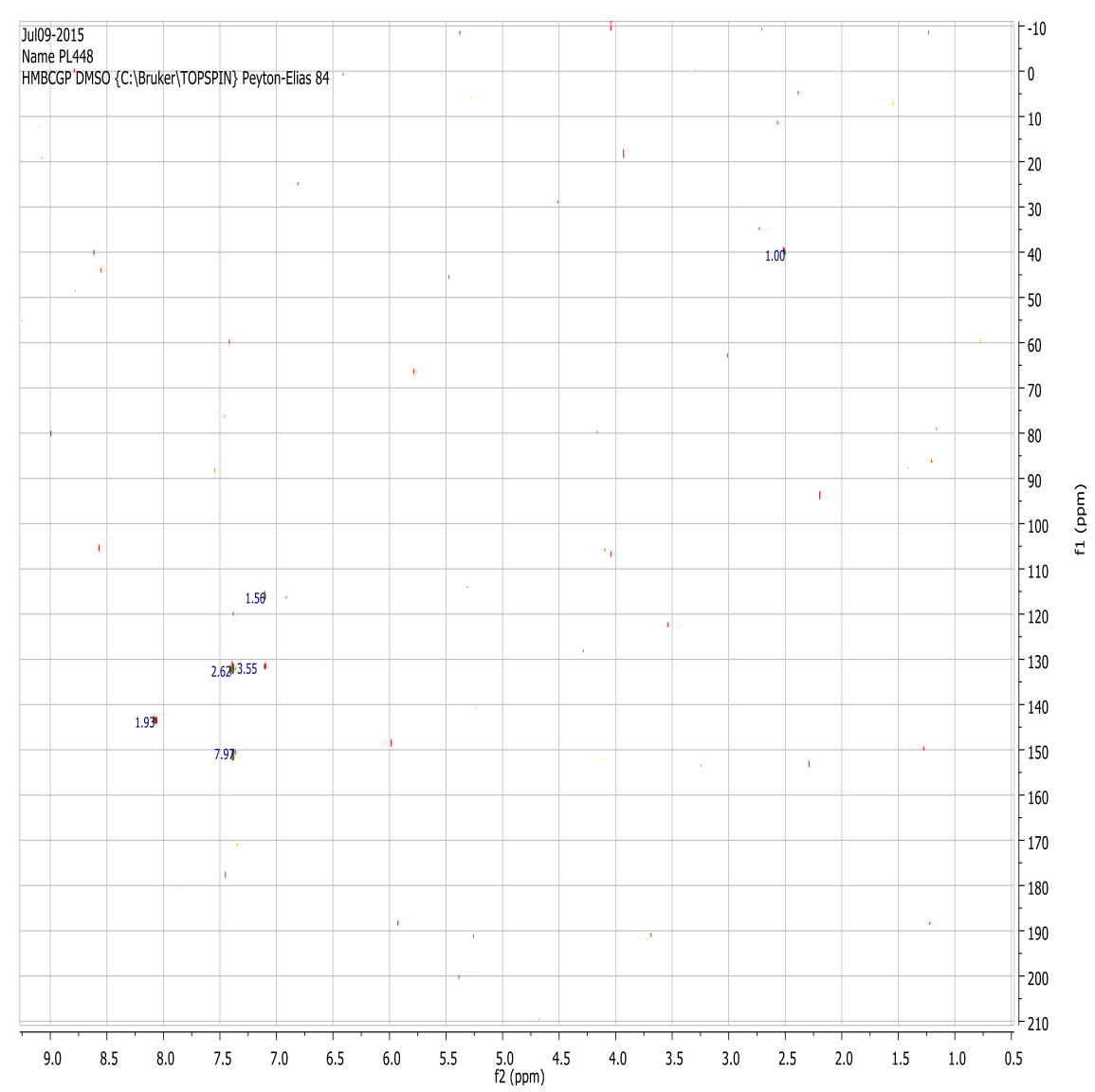

Figure 3.4. HMBC spectrum of PL448 


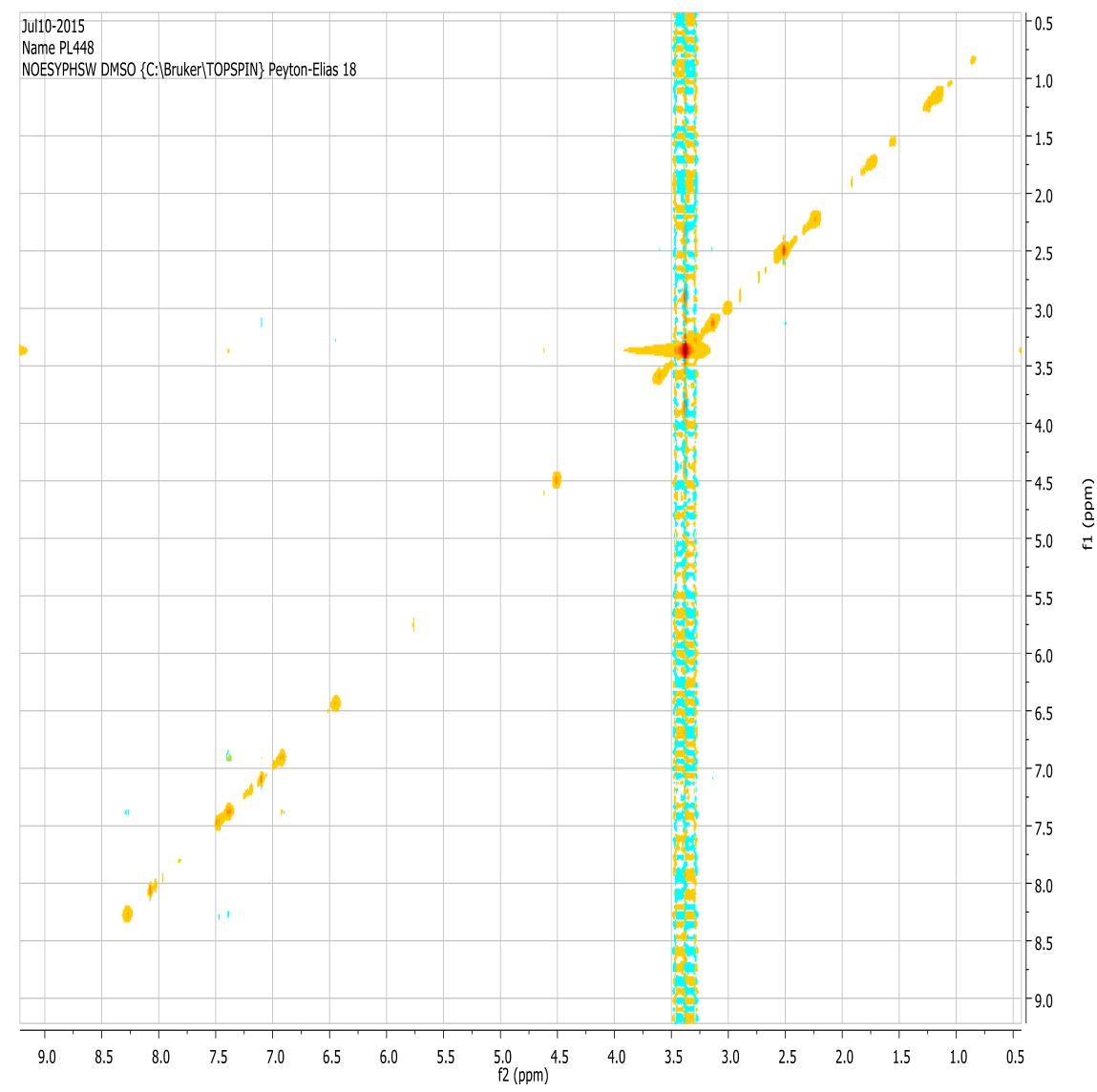

Figure 3.5. NOESY spectrum of PL448 


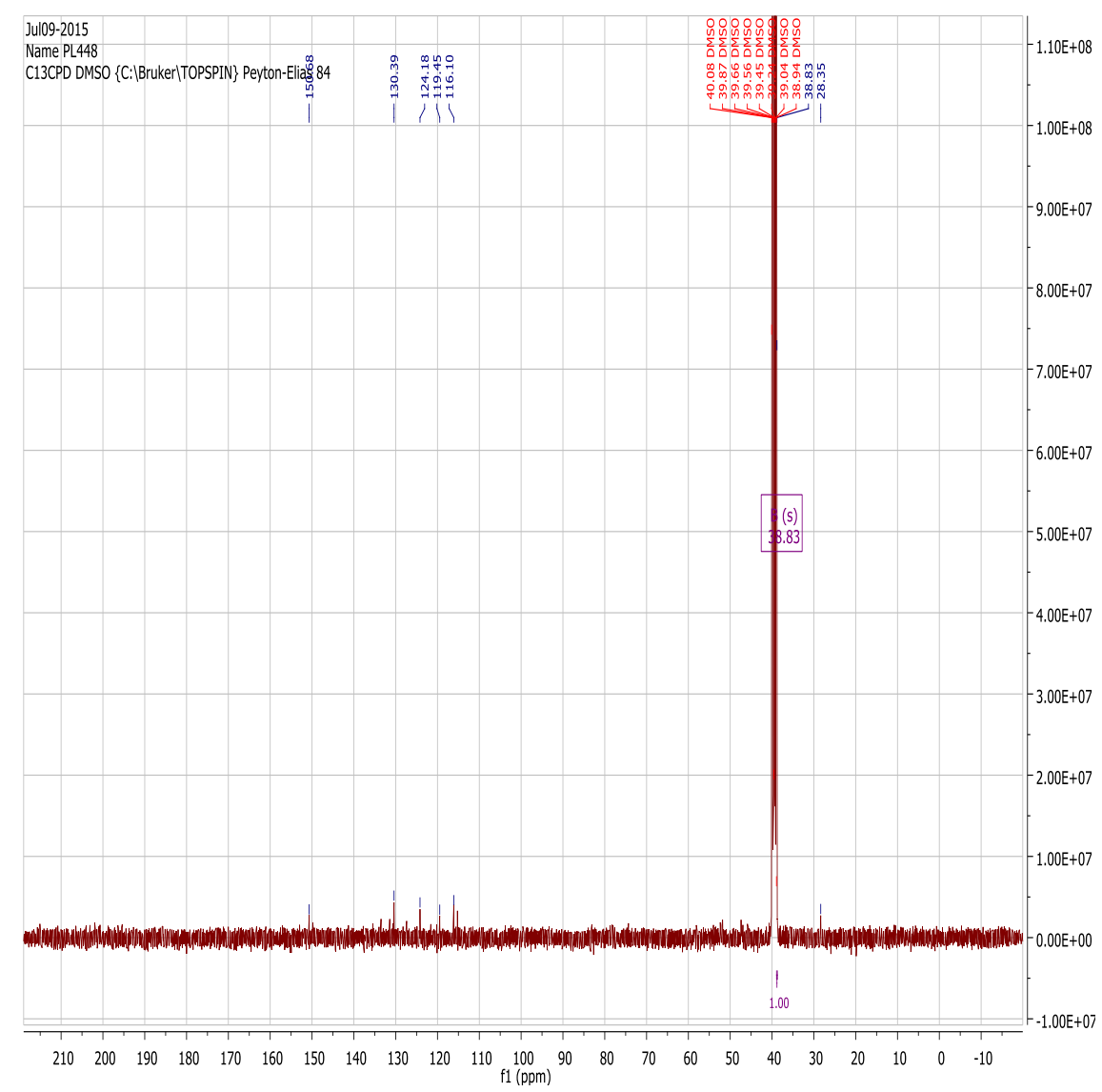

Figure 3.6. ${ }^{13} \mathrm{C}-$ Specrum of PL448 


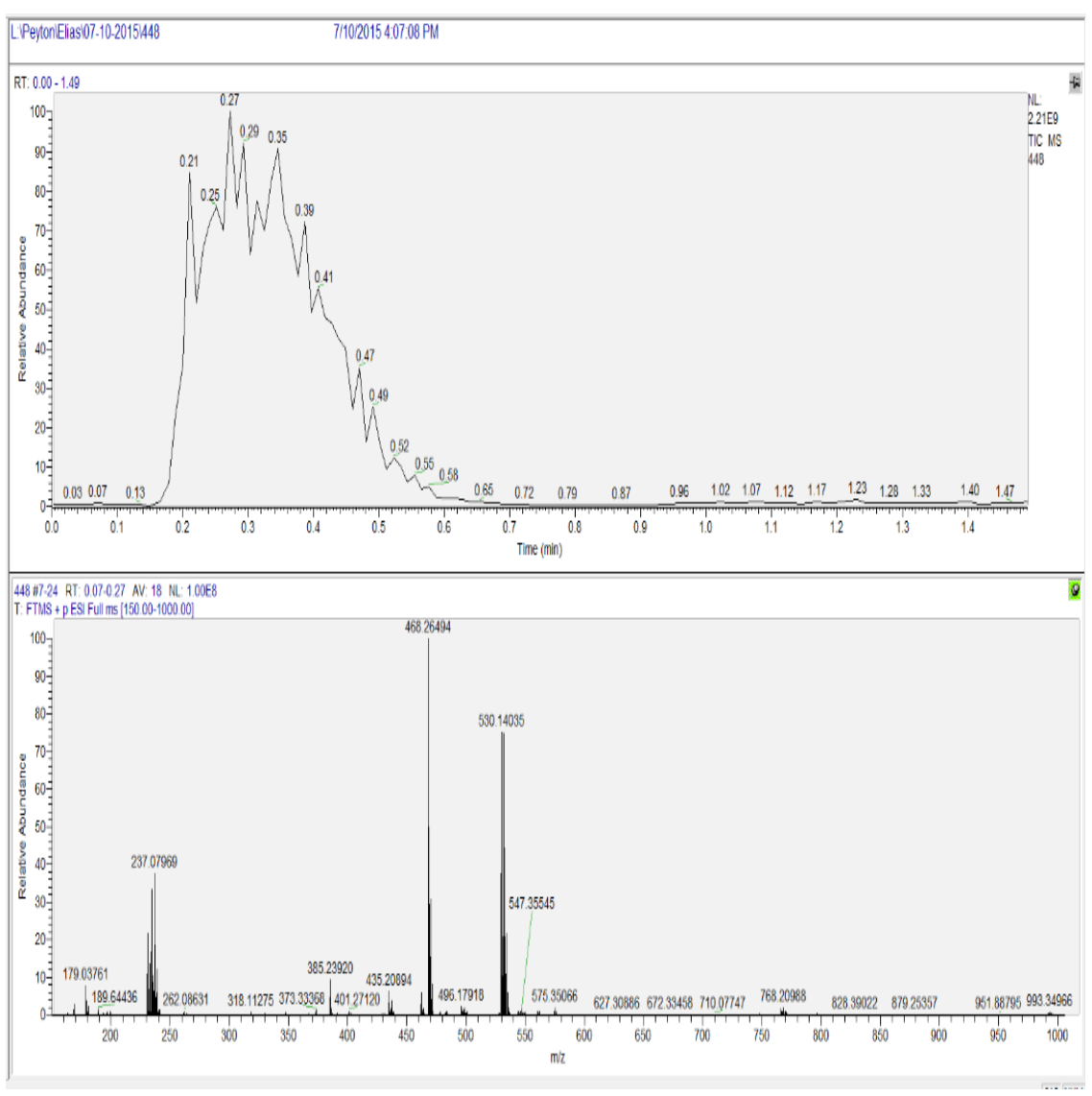

Figure 3.7. Mass spectrum of PL448 
Sample: ES-02-103

RediSep Column: Silica 40g

$2513372030 \mathrm{X}$

Equal Waste: 0.0 : $40.0 \mathrm{ml}$

Air Purge: $1.0 \mathrm{~min}$

Solvent: A2 ethyl acetate

Run Notes:

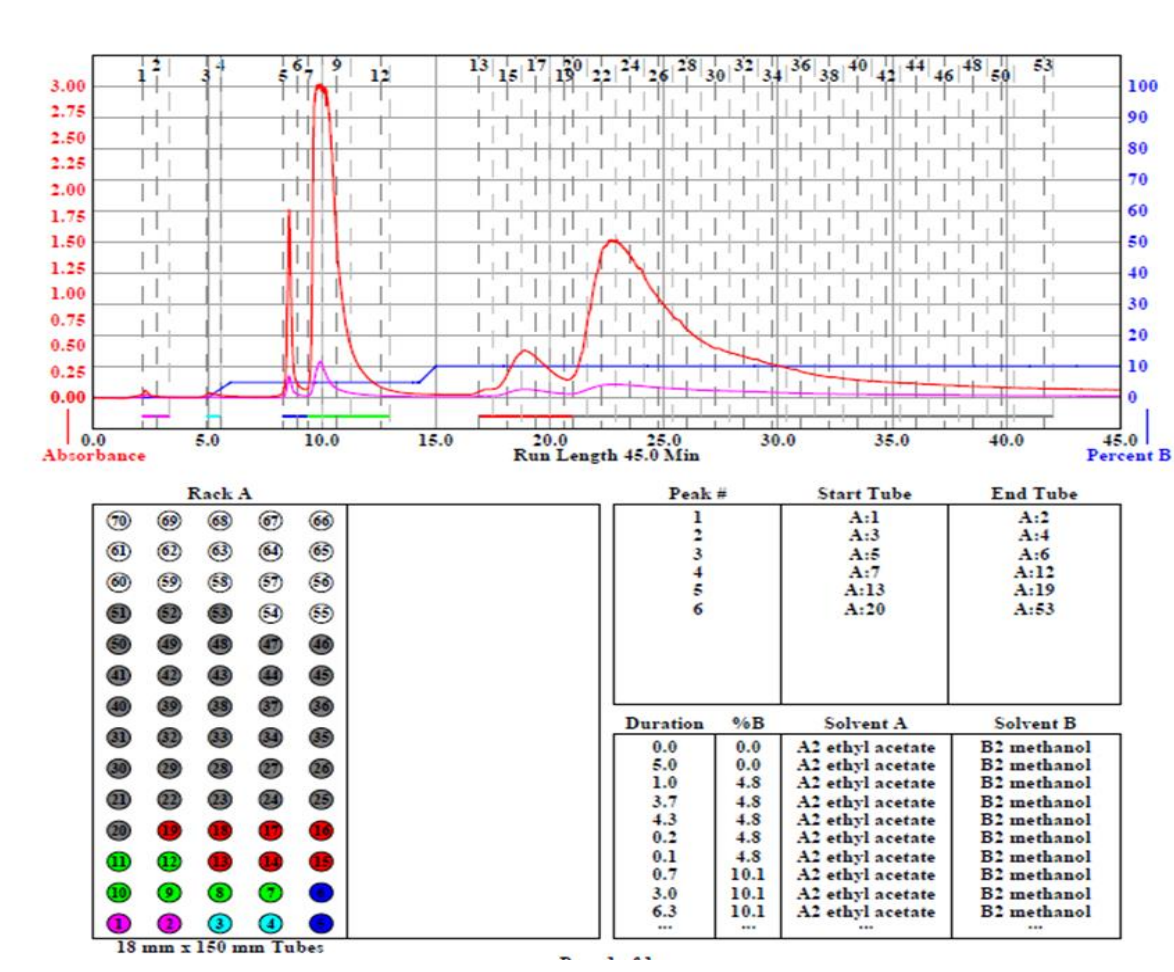

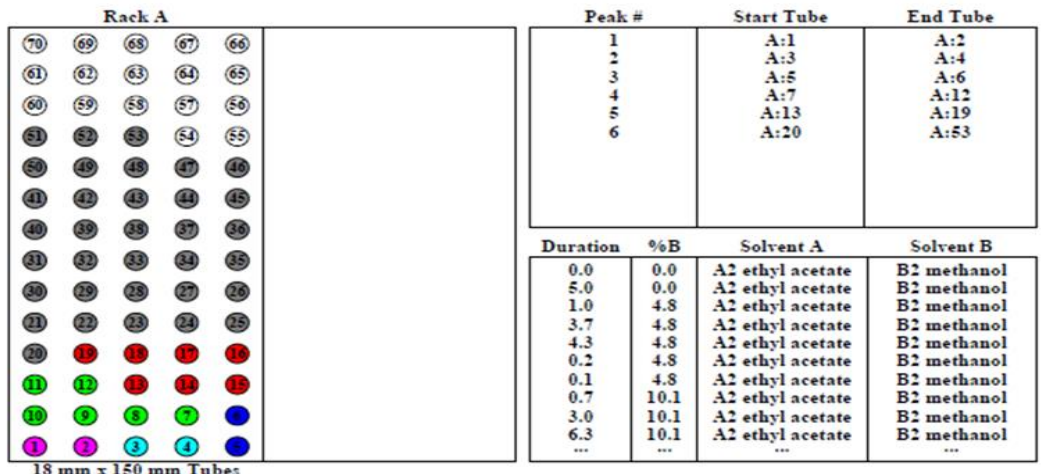

Figure 3.8. Combiflash chromatography of PL448

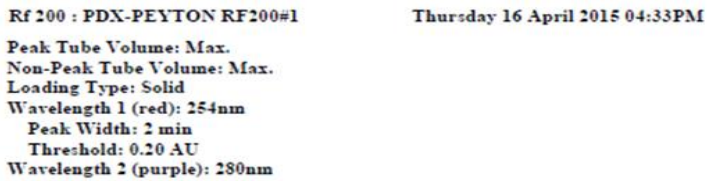

Warelength 2 (purple): $280 \mathrm{~nm}$ 


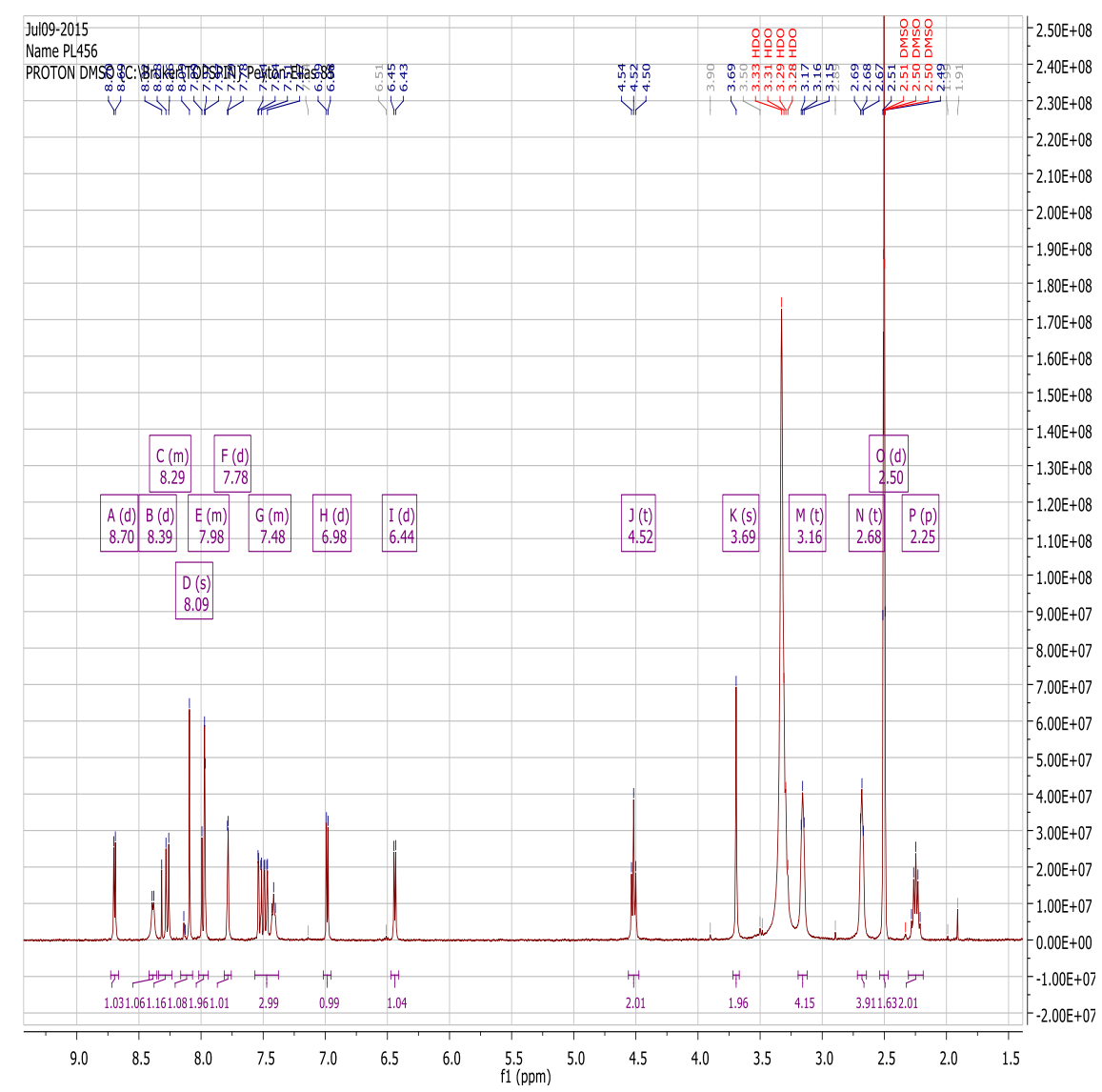

Figure 4.1. ${ }^{1} \mathrm{H}$-proton spectrum of PL456 


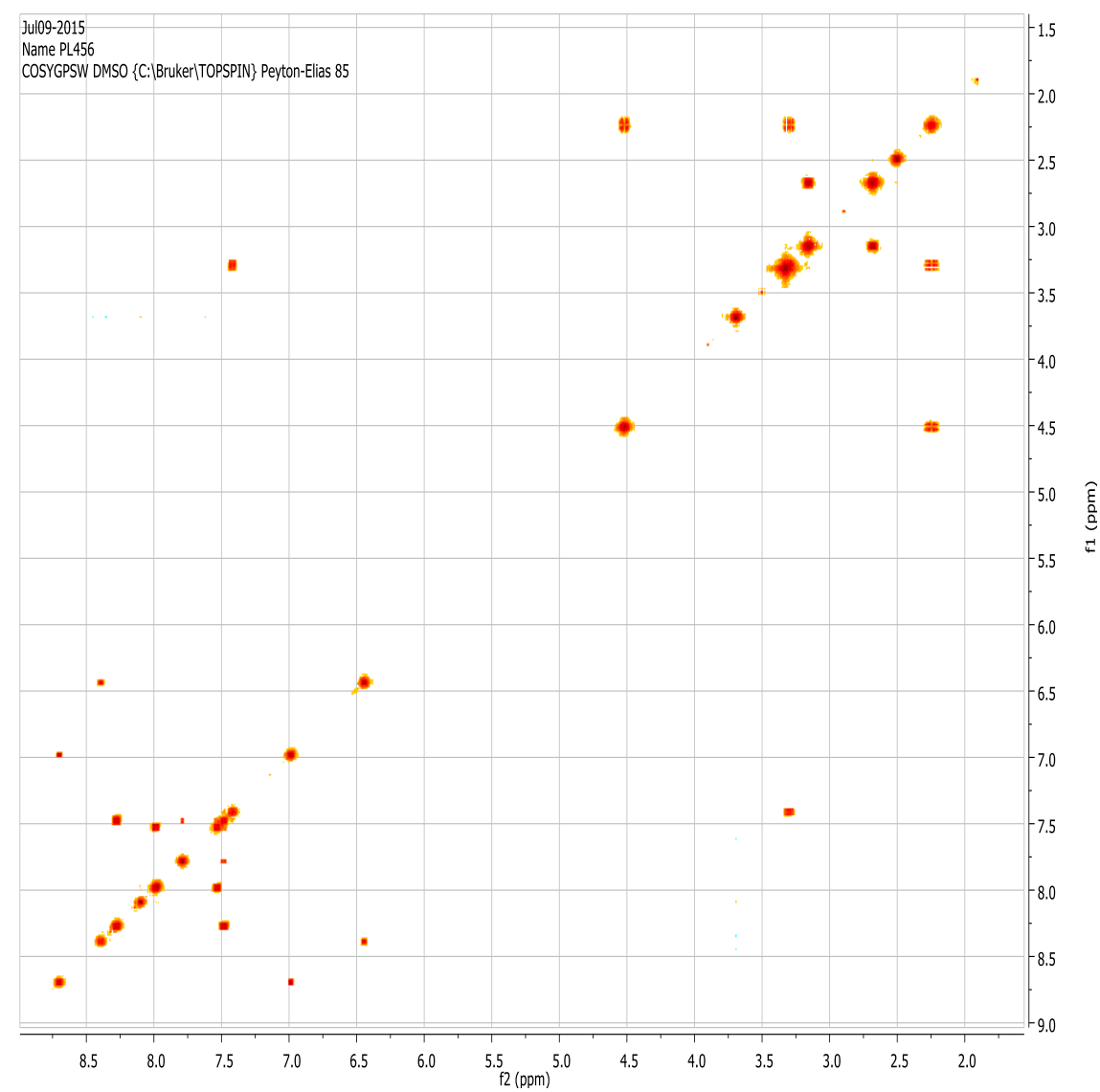

Figure 4.2. COSY spectrum of PL456 


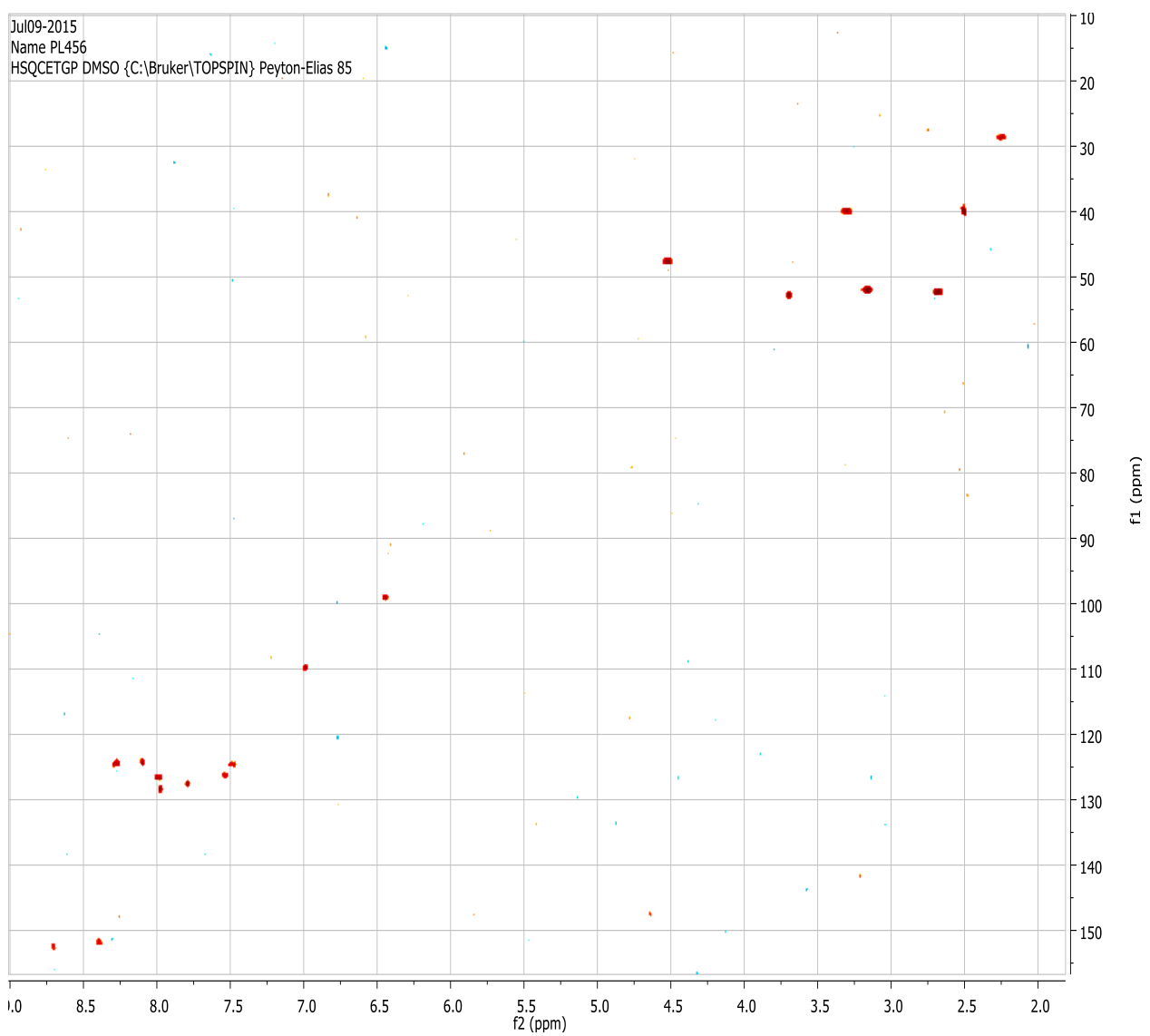

Figure 4.3. HSQC spectrum of PL456 


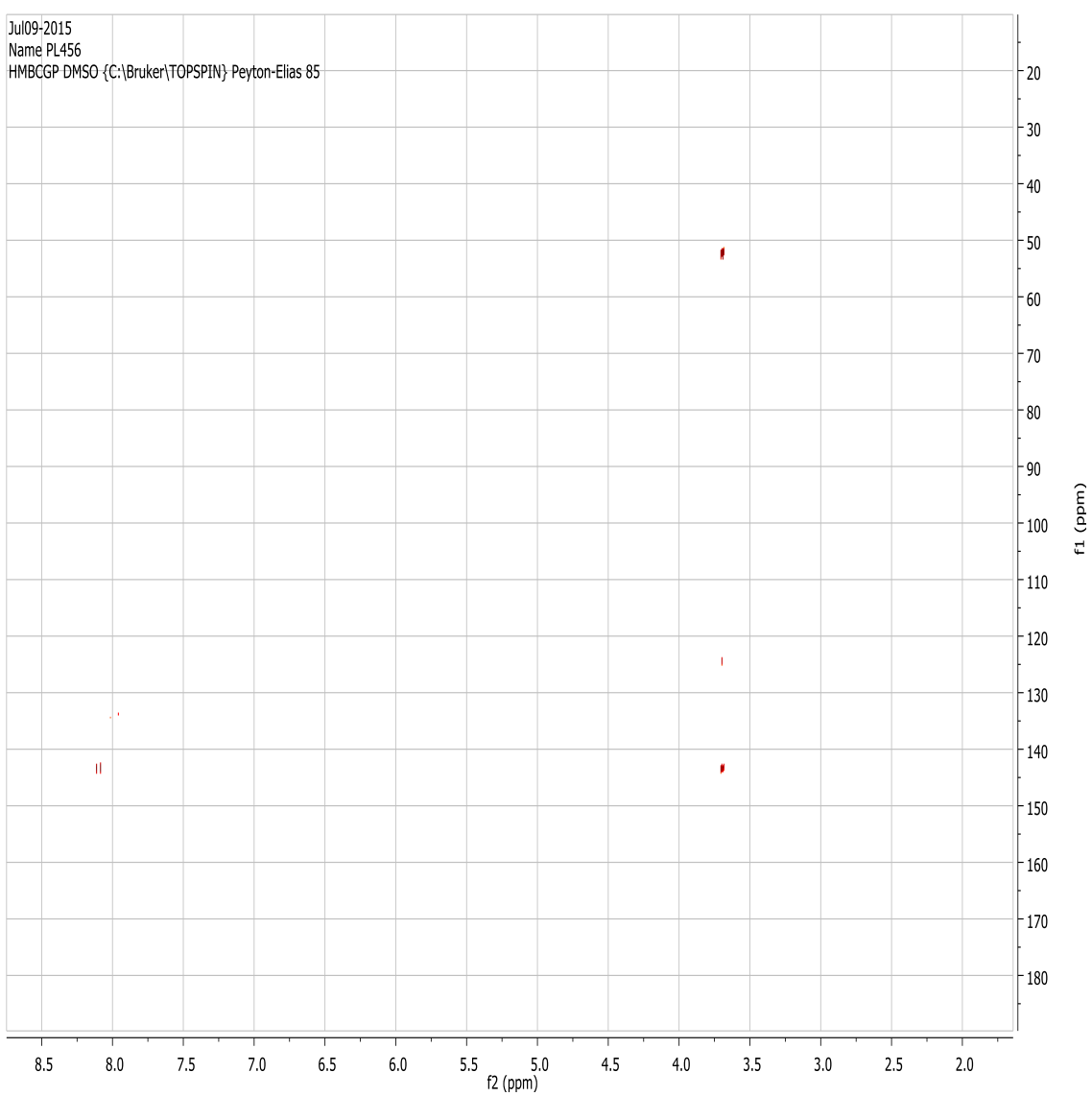

Figure 4.4. HMBC spectrum of PL456 


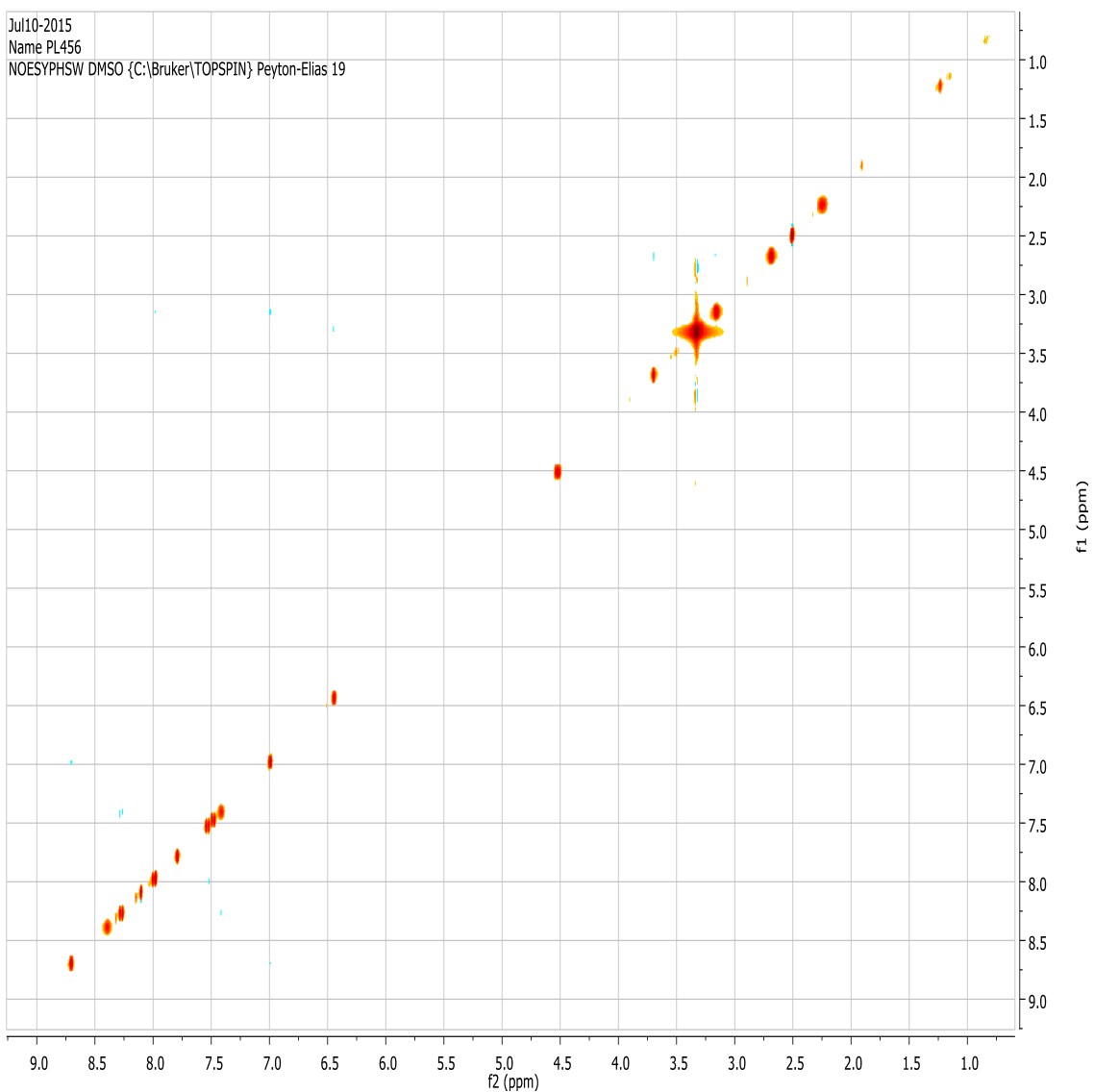

Figure 4.5. NOESY spectrum of PL456 


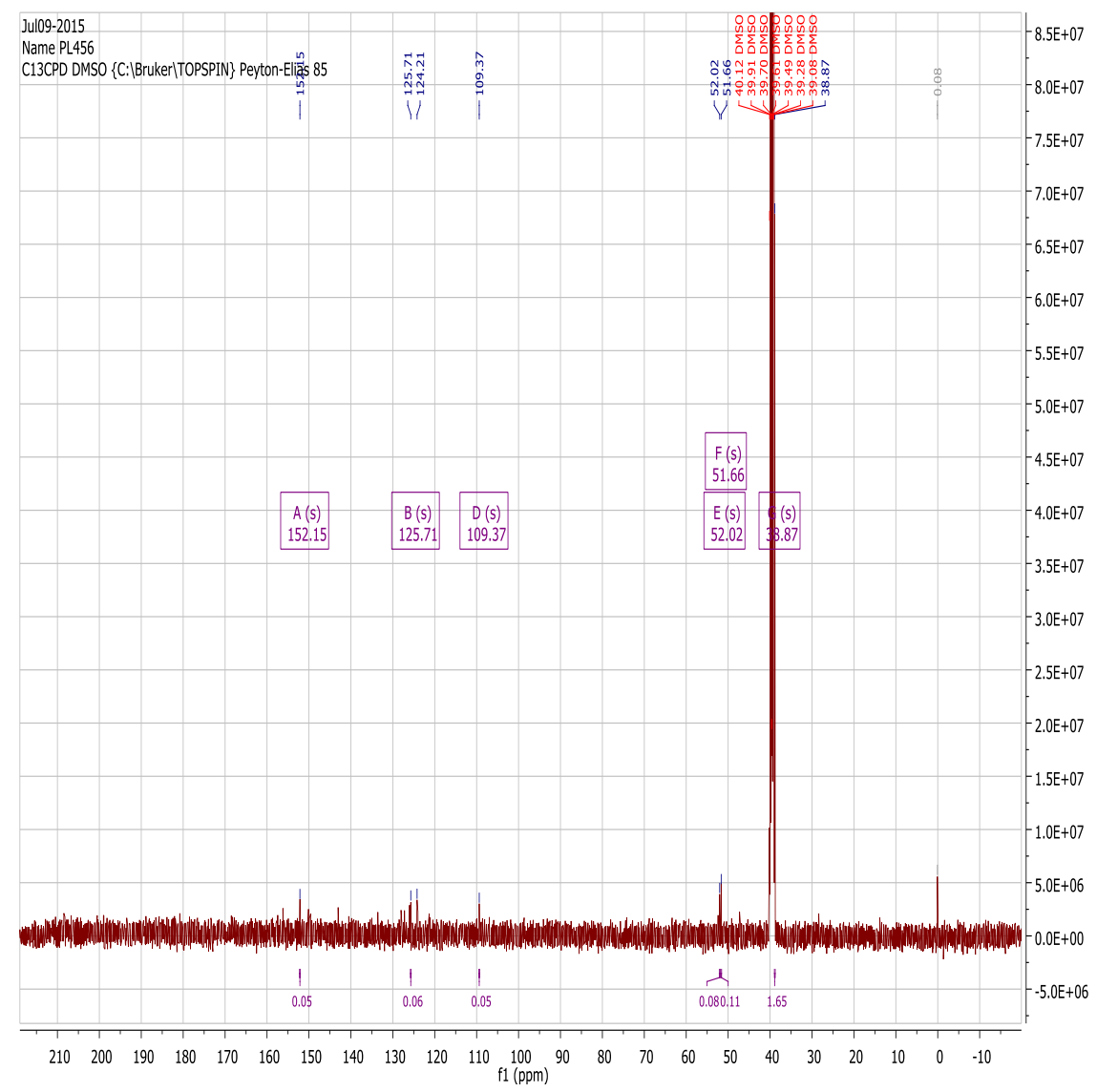

Figure 4.6. ${ }^{13} \mathrm{C}-$ Spectrum of PL456 


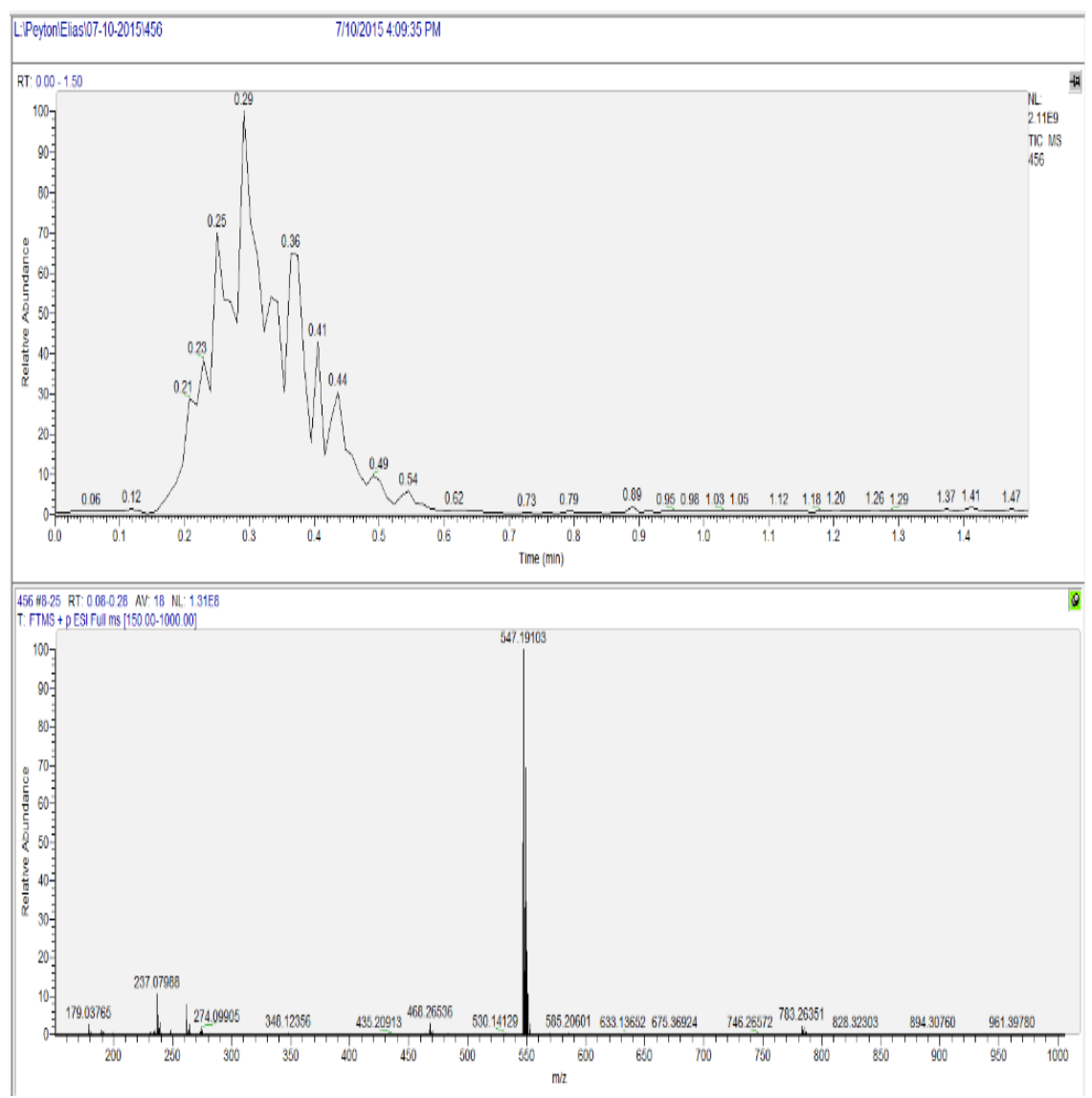

Figure 4.7. Mass spectrum of PL456 
Sample: ES-02-112

RediSep Column: Silica 40g

Lot: $2513372030 \mathrm{X}$

Flow Rate: $25 \mathrm{ml} / \mathrm{min}$

$240.0 \mathrm{~m}$

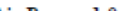

Air Purge: $1.0 \mathrm{~min}$

Solvent: $B_{2}$ methanol
Rf 200 : PDX-PEYTON RF $200 \# 1$

Peak Tube Volume: Max.

Non-Peak Tube Volume: Max.

Loading Type: Solid

Peak Width: 2

Threshold: $0.20 \mathrm{AU}$

Wavelength 2 (purple): $280 \mathrm{~nm}$

Run Notes:

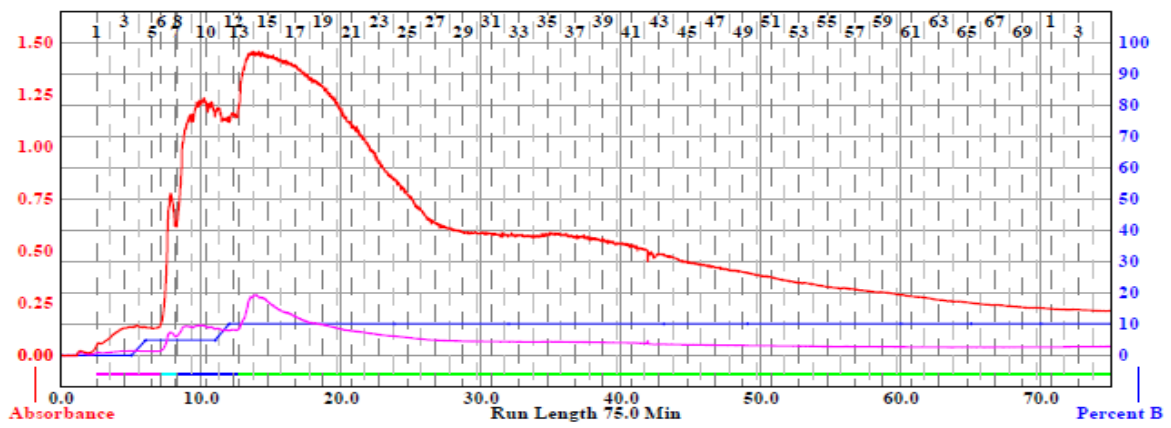

\begin{tabular}{|c|c|c|c|c|c|c|c|c|c|c|c|c|c|}
\hline \multicolumn{5}{|c|}{ Rack A } & \multicolumn{5}{|c|}{ Rack B } & \multicolumn{2}{|c|}{ Peak \# } & Start Tube & \multirow{2}{*}{$\frac{\text { End Tube }}{A: 5}$} \\
\hline (20) & & (6) & (6) & (6) & (70) & (6) & (68) & (67) & (6) & \multirow{3}{*}{\multicolumn{2}{|c|}{$\begin{array}{l}1 \\
2 \\
3 \\
4\end{array}$}} & $A: 1$ & \\
\hline (1) & (62) & (3) & (64) & 65 & (1) & (62) & (63) & (44) & (65) & & & $\begin{array}{l}A: 6 \\
A: 8\end{array}$ & $\begin{array}{l}\mathrm{A}: 7 \\
\mathrm{~A}: 12\end{array}$ \\
\hline (0) & (5) & (6) & (57) & (56) & 60 & (59) & (58) & (57) & (56) & & & $A: 13$ & $B: 5$ \\
\hline (1) & (22) & (23) & (54) & (5) & (51) & (52) & (33) & (54) & (55) & & & & \\
\hline (2) & (49) & (48) & (47) & (40) & (50) & (49) & (48) & (47) & (46) & & & & \\
\hline (41) & (42) & (43) & (44) & (45) & (41) & (42) & (43) & (44) & (45) & & & & \\
\hline (40) & (3) & (38) & (37) & (36) & (40) & (39) & (38) & (37) & (36) & & & & \\
\hline (31) & (32) & (33) & (34) & (35) & (31) & (32) & (33) & (34) & (35) & $\begin{array}{c}\text { Duration } \\
0.0\end{array}$ & $\begin{array}{l}\% \mathrm{~B} \\
0.0\end{array}$ & $\begin{array}{c}\text { Solvent } A \\
\text { A2 ethyl acetate }\end{array}$ & $\begin{array}{l}\text { Solvent B } \\
\text { B2 methanol }\end{array}$ \\
\hline (30) & (2) & (28) & (27) & (20) & (30) & (29) & (28) & (27) & (26) & 5.0 & 0.0 & A2 ethyl acetate & B2 methanol \\
\hline (21) & (22) & (23) & (24) & (25) & (21) & (22) & (23) & (24) & (25) & $\begin{array}{l}1.0 \\
5.0\end{array}$ & $\begin{array}{l}4.8 \\
4.8\end{array}$ & A2 ethyl acetate & B2 methanol \\
\hline 20 & 8 & 8 & 77 & 8 & 20 & (1) & 8 & (17) & 10 & 1.0 & 10.1 & A2 ethyl acetate & B2 methanol \\
\hline & & (12) & (11) & & (20) & (19) & (18) & (17) & (10) & 11.8 & 10.1 & A2 ethyl acetate & B2 methanol \\
\hline & & (13) & (14) & (15) & (11) & (12) & (13) & (14) & (15) & 8.2 & 10.1 & A2 ethyl acetate & B2 methanol \\
\hline & & & (7) & (6) & (10) & (9) & (8) & (7) & (6) & 6.0 & $\begin{array}{l}10.1 \\
10.1\end{array}$ & $\begin{array}{l}\text { A2 ethyl acetate } \\
\text { A2 ethyl acetate }\end{array}$ & B2 methanol \\
\hline (1) & (2) & (3) & (4) & (5) & (1) & (2) & (3) & (4) & (5) & 11.0 & 10.1 & A2 ethyl acetate & B2 methanol \\
\hline
\end{tabular}

Figure 4.8. Combiflash Chromatography of PL456 